\title{
Strategies of prevention: Extending the concept of preventive war and understanding its implications
}

\author{
Steven T. Walker \\ West Virginia University
}

Follow this and additional works at: https://researchrepository.wvu.edu/etd

\section{Recommended Citation}

Walker, Steven T., "Strategies of prevention: Extending the concept of preventive war and understanding its implications" (2008). Graduate Theses, Dissertations, and Problem Reports. 2747.

https://researchrepository.wvu.edu/etd/2747

This Dissertation is protected by copyright and/or related rights. It has been brought to you by the The Research Repository @ WVU with permission from the rights-holder(s). You are free to use this Dissertation in any way that is permitted by the copyright and related rights legislation that applies to your use. For other uses you must obtain permission from the rights-holder(s) directly, unless additional rights are indicated by a Creative Commons license in the record and/ or on the work itself. This Dissertation has been accepted for inclusion in WVU Graduate Theses, Dissertations, and Problem Reports collection by an authorized administrator of The Research Repository @ WVU.

For more information, please contact researchrepository@mail.wvu.edu. 


\title{
Strategies of Prevention: Extending the Concept of Preventive War and Understanding Its Implications
}

\author{
Steven T. Walker
}

Dissertation Submitted to the Eberly College of Arts and Sciences at West Virginia University in partial fulfillment of the requirements for the degree of

\author{
Doctor of Philosophy \\ In \\ Political Science
}

\author{
Joe D. Hagan, Ph.D., Co-chair \\ Scott Crichlow, Ph.D., Co-chair \\ Robert Duval, Ph.D. \\ Hong Kim, Ph.D. \\ James Siekmeier, Ph.D.
}

Department of Political Science

Morgantown, WV

2008

Keywords: preventive war, preventive action, international relations 


\section{Abstract \\ Strategies of Prevention: \\ Expanding the Concept of Preventive War \\ And \\ Understanding Its Implications}

\section{Steven T. Walker}

This dissertation contributes to the literature on prevention in two specific ways. First, it broadens the concept of preventive war, developing the idea that dominant states have a choice when it comes to dealing with rising challengers. The choice is not a dichotomous variable of either war or no war. Instead, there is a range of choices that decision makers within the dominant state have at their disposal. This dissertation examines the relationship - over timebetween two conflictual states, one in relative decline and the other in relative ascendance, and studies the response of the dominant but declining power. Second, I focus more than others have on the perceptions of decision makers and the workings of domestic politics in determining how dominant states respond to rising challengers. I use three broad historical case studies to empirically test my ideas about the extended concept of preventive action. Using components of the method of structured, focused comparison, I examine the internal domestic decision making processes of the cases. Finally, I utilize a foreign policy analysis approach and develop a model that illuminates nuances that have been largely overlooked in the scholarly literature. 


\section{Dedication}

This dissertation is dedicated to my lovely wife, Kristy.

Without her love and support, this dissertation would never have materialized.

It has been a long road, but we have finally made it. 


\section{Acknowledgements}

In any project that covers seven years, there are many people to thank for their invaluable assistance. First, I would like to thank the Co-chairs of my dissertation committee, Dr. Joe Hagan and Dr. Scott Crichlow. Dr. Hagan provided keen editing of earlier drafts and indispensable advice all along the way. Dr. Crichlow gave timely input every step of the way in this project, even when I was half a continent away. Without his help, this project would simply never have come to fruition. Second, I would like to thank the other members of the committee: Dr. Bob Duval, Dr. Hong Kim, and Dr. James Siekmeier. I would also like to thank Dr. Jamie Jacobs and Dr. Jason Parker, who were there in the beginning but have since moved on. Specifically, I would like to thank all of them for their patience in waiting for drafts and their suggestions that helped make this dissertation a better product.

I would also like to thank the Department of Political Science at West Virginia University for providing a pleasant and collegiate atmosphere within which to pursue a graduate degree. Specifically, Dr. Allan Hammock - who was the Chair of the department during my time in residency at WVU - should be commended for making the department a great place to study during his tenure. I would also like to thank the department for its financial support while I was in residence. This project would have been impossible without that support.

I would also like to thank the faculty, staff, and administration of Northwest College for providing financial and moral support over the past two years. A project of this length requires many resources, and without the support of Northwest College, this would have been impossible.

I have been fortunate to have many professors during my college career who encouraged me along the way and helped shape my thinking over the years. Key professors in this regard include the late Dr. Bernard V. Burke (Portland State University), Dr. Ronald Schlundt (University of Maryland, University College, European Division), and Dr. J. Thomas Hogle (University of Maryland, University College, European Division). These professors, and many others along the way, have helped foster my love of knowledge and my dedication to learning and teaching.

I would like to thank my parents, Ted and Leona Walker, for their love, support, and encouragement throughout my life. They deserve a great deal of credit for all that I accomplish.

Last, but certainly not least, I would like to thank my wife, Kristy, and our three children: Brittany, Rachel, and Anna, for their unconditional love, patience, and support as I pursued this degree. We have sacrificed much as a family to get to this point, but I am confident that it all has been worth it.

Of course, any errors or omissions are mine alone. 


\section{Table of Contents}

Abstract $\quad$ ii

Dedication $\quad$ iii

Acknowledgements

Table of Contents $\quad$ V

List of Tables $\quad$ viii

List of Figures $\quad$ ix

Chapter One-Introduction 1

Chapter Two-Literature Review

- International Systems Theory and Preventive War 9

- Balance of Power Theory and War 10

- Power Transition Theory and the Hierarchy of the International System 12

- Hegemonic Stability Theory and Prestige 16

- Perception and Preventive War 16

- Empirical Work 18

- State Level Theories and Preventive War 20

- Conclusion-Expanding the Concept and Examining Domestic Factors 25

Chapter Three-The Domestic Politics Model of Prevention (DPMP) 27

- Assumptions of the DPMP: Prospect Theory 28

- Components of the DPMP 29

- Causal Mechanism 1: Internal Power Constraints 29

- Causal Mechanism 2: Domestic Political Constraints 32

- Causal Mechanism 3: Ruler Belief Systems 34

- Dependent Variable: Form of Preventive Action 45

- Testing the DPMP 48

- Hypotheses 49

- Alternative Model 1: Offensive Realism as a Structural Model of Preventive War 52

- Alternative Model 2: Schweller's Democratic Peace as a Model of Preventive War/Action 54

- Methodology 55

- The Method of Structured, Focused Comparison 55

- The Case Study Method 56

- Process Tracing $\quad 63$

- Typological Theories 66

Chapter Four - The Decline of the United Kingdom 70

- Power Relations $\quad 71$

- Nature of the Threat $\quad 76$

- Economic Threats 76

- Military Threats $\quad 87$

- Continental Powers $\quad 88$ 
- United States $\quad 98$

- Japan 105

- Analysis 108

- Conclusion 123

Chapter Five-The Decline of Russia and the Soviet Union 124

- A Brief History to $1816 \quad 124$

- Power Relations 125

- Nature of the Threat 130

- Economic Challenges 130

- Military Threats 135

- Germany (1816-1938) 142

- United Kingdom (1936-1946) 145

- United States (1816-1860) 146

- Japan (1860-1944) 146

- Analysis 148

- Conclusion 164

Chapter Six — The Decline of the United States 165

- A Brief Overview of American Power and Foreign Policy 165

- Power Relations 167

- Nature of the Threat 171

- Economic Challenges 173

- Russia/Soviet Union 173

- Prussia/Germany 174

- Japan 174

- United Kingdom 177

- Military Threats 177

- Russia/Soviet Union 177

- Prussia/Germany 190

- Japan 199

- United Kingdom 205

- Analysis 207

- Conclusion 248

Chapter Seven—Conclusion 253

- The Models: Reviews and Evaluations 255

- Alternative Model 1: John Mearsheimer's Offensive Realism Model 255

- Alternative Model 2: Schweller's Democratic Peace as a Model of Preventive War/Action 258

- The Domestic Politics Model of Prevention 267

- Which Model—or Models_-Works Best? 272

- Implications 277

- Conclusion 278 
Bibliography 282

Appendix A: The Decision Making Process in the Domestic Politics Model of Prevention 289

Appendix B: A Typology of Preventive Action 310

Appendix C: Selected Polity IV Scores 311 


\section{List of Tables}

Table 4.1-A Typology of Preventive Action 109

Table 4.2-Mearsheimer's and Schweller's Predicted Outcomes 122

Table 5.1-A Typology of Preventive Action 149

Table 5.2-Mearsheimer's and Schweller's Predicted Outcomes 163

Table 6.1-A Typology of Preventive Action $\quad 207$

Table 6.2-Mearsheimer's and Schweller's Predicted Outcomes 247

Table 7.1-Summaries of Model Performance 273 


\section{List of Figures}

Figure 4.1-United Kingdom-United States CINC Scores $\quad 71$

Figure 4.2-United Kingdom-Germany CINC Scores 73

Figure 4.3-United Kingdom-Japan CINC Scores $\quad 74$

Figure 4.4-United Kingdom-Russia CINC Scores $\quad 75$

Figure 5.1-Russia-United States CINC Scores 126

Figure 5.2-Russia-Germany CINC Scores 127

Figure 5.3-Russia-Japan CINC Scores 128

Figure 5.4-Russia-United Kingdom CINC Scores 129

Figure 6.1-United States-Russia/Soviet Union CINC Scores 168

Figure 6.2-United States-United Kingdom CINC Scores 169

Figure 6.3-United States-Prussia/Germany CINC Scores 170

Figure 6.4-United States-Japan CINC Scores 171 


\section{Chapter One \\ Introduction}

This dissertation contributes to the literature on prevention in two specific ways. First, it broadens the concept of preventive war, developing the idea that dominant states have a choice when it comes to dealing with rising challengers. The choice is not a dichotomous variable of either war or no war. Instead, there is a range of choices that decision makers within the dominant state have at their disposal. This dissertation examines the relationship - over timebetween two conflictual states, one in relative decline and the other in relative ascendance, and studies the response of the dominant but declining power. Second, I focus more than others have on the perceptions of decision makers and the workings of domestic politics in determining how dominant states respond to rising challengers. I use three broad historical case studies to test empirically my ideas about the extended concept of preventive action. Using process tracing, and other elements of the method of structured, focused comparison, I examine the cases, studying the internal domestic decision making process regarding whether to initiate preventive action against a rising challenger. Finally, I utilize a foreign policy analysis approach and develop a model that illuminates nuances that have been largely overlooked in the scholarly literature. ${ }^{1}$

Preventive war, as a concept, is rooted in antiquity, has evolved over the ages, and remains a prominent perspective in international relations literature on the origins of war. The idea of preventive war can be traced back to Thucydides' history of the Peloponnesian War. The actual term "preventive war" was first used by Thomas Fuller in his 1639 book The History of the Holy War, which examined the Crusades. More recently, a rich theoretical literature on preventive war has emerged in contemporary international relations beginning with the works of Hans Morgenthau (1948, 1967), A.F.K. Organski (1958, 1968), and Robert Gilpin (1981). Jacek

\footnotetext{
${ }^{1}$ The title of this dissertation was inspired by John Lewis Gaddis' influential book Strategies of Containment: A Critical Appraisal of Postwar American National Security Policy.
} 
Kugler (1980), Jack Levy (1987), and Dale Copeland (2000) contributed to this literature by further refining the theory of preventive war.

A basic concept of preventive war revolves around the idea of a conflictual pair of states (or dyad) containing a dominant but relatively declining state and a rising but still relatively weak challenger. Fear, on the part of the dominant power, is a key aspect of this dyad, and the literature suggests it may take several forms. ${ }^{2}$ There may be a fear that military conflict, while not imminent, is highly likely or inevitable in the end. Alternatively, the fear may be of a less critical sort, perhaps a more vague perception that the status quo will get worse if no action is taken. There may also be the concern that an adversary may cross some precarious threshold of military or technological capability—such as attaining weapons of mass destruction. Much of the literature suggests that any one or a combination of these fears will spark a preventive war designed to stop the relative ascendance of the challenger or to lessen the impact of an eventual conflict. $^{3}$

This dissertation questions the inevitability of war given the international situation in which one state is rising vis-à-vis another state over time. I will explore whether the dominant state will react militarily to the challenger. In contrast to much of the established literature, my perspective is that, given such circumstances, dominant states do not necessarily initiate military action. Instead, I suggest that over time, dominant but declining states have choices regarding

\footnotetext{
${ }^{2}$ The other side of this equation is that of the aspirations of the rising power, which may also result in war. However, the focus of this dissertation is on the dominant power, and the actions it may take to stop the rise of a challenger.

${ }^{3}$ It should be noted that prevention is very different from preemption. Prevention occurs over a relatively large expanse of time in which conflict is not seen as imminent. Prevention anticipates that sometime in the futureperhaps even somewhat distant future - a rival will gain some capability that will put one's state at risk. Preventive action is a strategic response to a long-term threat that may even be years in the making. It is designed to preclude the development of new military assets or other strategic capabilities, or prevent the possible use of existing, but not yet mobilized, capabilities. Preemption, on the other hand, is a tactical response to a threat of an attack that is perceived to be imminent. Any action to lessen an imminent attack's impact would be preemptive. Such an action is designed to thwart an enemy who is mobilizing or otherwise clearly preparing to use an existing military force. See chapter 2.
} 
how they respond to rising challengers. They may react in a variety of ways, manifested by different policy strategies. These responses take alternative forms of what I will call "preventive action." ${ }^{4}$ At the benign end of the spectrum, dominant states may choose not to respond or be unable to respond in any substantial way to a rising challenger. They may also acquiesce to the demands of the challenger. Alternatively, a dominant state may choose to confront or contain the rising challenger using carrots and sticks, hoping to achieve the best possible outcome for itself without provoking the challenger. Moving to the more coercive end of the preventive action spectrum, a dominant state may engage in sustained coercive or militant diplomacy with the challenger. Finally, the dominant state may initiate the most severe form of preventive action, preventive war, against the challenger.

In this project, I will try to explain why a state chooses a particular type of preventive action. Much of the literature on preventive war has focused on systemic and structural components in determining whether the dominant state will initiate preventive war. This project focuses more closely on decision makers' perceptions, choices, and interactions at the domestic level. I suggest there is an element of choice that plays a key role in determining the policy of a state. In essence, I focus more than others have on the domestic dimension of preventive action initiation.

Inherent in the idea of preventive action is a relationship that evolves between states over time - not simply the immediate origins of war. This insight shapes the empirical part of my dissertation. In order to capture this relationship, my case studies are rather extensive and

\footnotetext{
${ }^{4}$ I use the term "preventive action" in this project to encompass the entire range of responses a dominant state may undertake regarding a rising challenger. The term, as used here, should be understood in a different context than some other uses of the same term. For example, some authors have used "preventive action" to mean economic and diplomatic policies aimed at preventing war from occurring. Examples of such work include Michael S. Lund, Preventing Violent Conflicts: A Strategy for Preventive Diplomacy (Washington, D.C.: United States Institute of Peace Press, 1996). and Barnett R. Rubin, ed., Cases and Strategies for Preventive Action (New York: The Century Foundation Press, 1998). My use of the term is quite different from these authors. As used in this dissertation, "preventive action" refers to an attempt on the part of the dominant state to stop the further rise of the challenger.
} 
encompass broad historical time frames. In the empirical sections of my dissertation, I will examine three major historical episodes in which dominant states dealt with rising challengers. These three cases are as follows:

1) How the United Kingdom coped with relative decline from 1816 to 1914.

2) How Russia coped with relative decline from 1816 to 1997.

3) How the United States dealt with relative decline from 1816 to 1996.

Regarding the cases, my goal is not to present a narrative, but instead to isolate key policies that states employed over decades if not centuries. In order to capture, in a systematic way, how the dominant state sought to respond to the rise of the challenger, I utilize the method of focused, structured comparison and its various components as proposed by Alexander George and Andrew Bennett. ${ }^{5}$ Process tracing and the development of a typological theory, two components of structured, focused comparison, assist in the explanation of why dominant states react to rising challengers the way they do. This methodology teases out relevant material and key theoretical elements that illuminate individual and domestic level decision making regarding preventive action.

When examining our case studies, several things must be kept in mind. First, it is essential to determine objectively if there is a declining dominant power and a rising challenger, and which state is which. This is not easy, but using the National Materials Capabilities data set from the Correlates of War project simplifies this matter. ${ }^{6}$ Fortunately, this data is available

\footnotetext{
${ }^{5}$ Alexander L. George and Andrew Bennett, Case Studies and Theory Development in the Social Sciences, BCSIA Studies in International Security (Cambridge, Massachusetts: MIT Press, 2005).

${ }^{6}$ In order to make the data comparable across cases, I use the Composite Index of National Capability data from the National Material Capabilities v. 3.02 data set. This data can be found at http://www.correlatesofwar.org/.
} 
starting in 1816, which meshes nicely with our focus on modern states. Using this dataset, I am able to determine objectively when a state is in relative decline vis-à-vis other states. ${ }^{7}$

Second, we must determine the policy strategies of the declining dominant power, and determine whether these policies were targeted at a rising challenger. To do this we can look at the level of fear shared by policy makers in the declining dominant state regarding the rising challenger. We must also ask ourselves the question, "What do these policy makers fear?” For example, if policy makers in our declining dominant power (state A) are concerned that our rising challenger (state B) is developing a military capability that will render A's military obsolete, and then launches a war against B, we can with some confidence suggest that this was preventive action. In our analysis then, we must bring these elements together to determine the validity of our model.

In looking at the cases in this study, I am essentially trying to fill a gap in deterministic structural theories such as neorealism, hegemonic stability theory, and power transition theory. One way to do this is to examine the political leaders who are actually making the decisions and determining policy. Through process tracing, I accomplish this goal, and provide a better explanation of why states experiencing relative decline have pursued the policies they have. ${ }^{8}$

The cases in this study reveal complex and varied responses to relative decline by dominant powers. What the cases show is that declining states tend to prefer non-militarized preventive action when facing a rising challenger. Only on rare occasions did the declining

\footnotetext{
${ }^{7}$ See Aaron L. Friedberg, The Weary Titan: Britain and the Experience of Relative Decline, 1895 - 1905 (Princeton, New Jersey: Princeton University Press, 1988). One important question I am trying to answer here is to what extent political leaders are successful in gauging their own states relative decline vis-à-vis other nations. The Material Capabilities Index I use presents an objective way to gage this, but do political leaders at the time perceive this relative decline? I hope to discover this by looking at individual leaders and groups in the domestic sphere. See Friedberg 4-17 for a discussion regarding the ability of political leaders to gage this decline, and different models that address this issue. On the issue of perception of decline by political leaders, Friedberg seems to disagree with Kupchan's argument that the political elite are quite perceptive and willing to accept and react to these changes. ${ }^{8}$ Ibid., 18.
} 
dominant state engage in behavior that was likely to result in militarized conflict. For example, the United States after the Second World War enjoyed military superiority over the rest of the world's nations. By the end of 1947 or 1948 it was clear to American decision makers that the Soviet Union was going to constitute a serious challenge to American global leadership in the years and perhaps decades to come. Nonetheless, President Harry S Truman and his successors did not engage in preventive war, but instead chose a form of non-militarized preventive action to contain the communist bloc. In another example, facing relative decline vis-à-vis Japan in the second half of the nineteenth century, Britain chose to ally itself with the Japanese, and not confront them in any way.

It is clear from the cases presented in this dissertation that dominant states have a choice when it comes to dealing with rising challengers. It is not simply a decision of war or no war, but instead we find that decision makers within the dominant state have at their disposal a range of options. By focusing more than others have on the perceptions of decision makers and the workings of domestic politics in determining how dominant states respond to rising challengers, this study builds on the work of other scholars to develop a model of preventive action that better explains why national leaders choose the policies they do when faced with relative decline. 


\section{Chapter Two Literature Review}

I define a preventive action ${ }^{1}$ as one in which a dominant but relatively declining state takes some action against a rising but still inferior challenger ${ }^{2}$ with the primary goal of forestalling the continued ascendance of the challenger. ${ }^{3}$ Given these general circumstances, two things may be viewed by the dominant state as likely or inevitable: 1) its continued relative decline, and 2) the possibility of eventual conflict, whether militarized or otherwise, with the challenger. In such an instance, the dominant state will see action taken now as providing an advantage over waiting for the situation to deteriorate further. "Preventive motivation" is the term Jack Levy has given this "perception that one's military power and potential are declining relative to that of a rising adversary, and...the fear of the consequences of that decline." ${ }^{4}$ The presence of this preventive motivation is essential in defining any action as preventive in nature.

Before discussing the manner in which the concept of prevention has evolved, it is prudent to differentiate between prevention and preemption. The two can be separated primarily in terms of urgency and the time frame in which the conflict occurs. ${ }^{5}$ The element of immediacy, or more importantly, the absence thereof, is essential when discussing preventive action. Prevention anticipates that sometime in the future-perhaps even somewhat distant future- $\mathrm{a}$ rival will gain some capability that will put one's state at risk. Preventive action is a strategic

\footnotetext{
${ }^{1}$ From this point on, I use the terms "preventive action" and "prevention" synonymously.

${ }^{2}$ For the purpose of readability, I will use the terms "dominant" and "dominant state" to refer to a dominant but relatively declining state and the term "challenger" to refer to a relatively weak but rising challenger. It is important to recognize that dominant states experiencing relative decline might not be declining in absolute terms. The key here is looking at differential rates of growth between states. If the dominant state is growing, though at a slower rate than a rising challenger, it is still experiencing relative decline.

${ }^{3}$ Some scholars suggest that prevention can also be seen in the form of a declining state that might not be superior, if that declining state believes that militarized conflict with the dominant state is inevitable, and that a war fought now would be fought under better conditions than a war fought later. This latter part is the common thread in all preventive action, and I do not deny the possibility of initiation by a declining non-superior state, but my focus is on a dominant state's initiation of preventive action.

${ }_{5}^{4}$ Jack S. Levy, "Declining Power and the Preventive Motivation for War," World Politics 40, no. 1 (1987).

${ }^{5}$ Levy suggests that the two can be differentiated along several dimensions. I do not find this more helpful than the simpler element of time advanced here. Ibid.
} 
response to a long-term threat that may even be years in the making. It is designed to preclude the development of new military assets or other strategic capabilities, or prevent the possible use of existing, but not yet mobilized, capabilities. ${ }^{6}$ For the preventive scenario, failure to act immediately risks future geo-political, economic, or military uncertainty, and perhaps a higher risk of a more costly conflict or an increasingly deteriorating status quo. While, in the case of a militarized threat, attack is not imminent, it is believed that conflict with the challenger is ultimately likely and perhaps inevitable. In contrast, if conflict were imminent or perceived as imminent, any action would be tactical and not strategic in nature. Such a response falls under the rubric of preemption. Stephen Van Evera suggests that a preemptive attack is designed to thwart an enemy who is mobilizing or otherwise clearly preparing to use an existing military force. In the instance of a preemptive situation, failure to act right away risks immediate attack by an aggressor. A preemptive attack is "mounted to seize the initiative, in the belief that the first mover gains an important advantage..."7

While militarized threats have been the focus of much of the literature, non-militarized threats, usually in the form of economic competition, can also lead to insecurity on the part of the

\footnotetext{
${ }^{6}$ Ibid.

7 Stephen Van Evera, Causes of War: Power and the Roots of Conflict (Ithaca and London: Cornell University Press, 1999), fn. 18, 40. A word should be said about the relationship between preventive action and deterrence/compellance. The connection between the two concepts is a complex one. Deterrence and compellance both involve the threat to use force either in order to prevent an adversary from taking some action, to stop an adversary from continuing an action it is already taking, or to get an opponent to initiate some action it is not currently taking. See Patrick M. Morgan, Deterrence Now (New York: Cambridge University Press, 2003), especially 1-25. The key with both deterrence and compellance is that these are threats that force may follow. If these threats are issued by a dominant state against a rising challenger, with the hope that such threats will stop the development of strategic capabilities, this may in fact be a form of preventive action according to the guidelines I have outlined above. This is not to say, however, that all deterrence falls within the purview of preventive action. During the Cold War when both the United States and the Soviet Union exercised Mutually Assured Destruction, they were using deterrence but not preventive action. There was no attempt to prevent the rise of a challenger, only the threat that any use of already available assets would result in annihilation. However, if the Soviet Union during the 1980s had issued a threat to the United States that if the U.S. went forward with the Strategic Defense Initiative (SDI) it would automatically result in a Soviet invasion of Europe, and this threat had been issued with the hopes that such a threat would stop the U.S. from developing SDI, then such a threat would be both deterrence and preventive action. I would like to thank Dr. Robert Duval for bringing this to my attention.
} 
leadership and populace of the dominant state. Instances of these non-militarized threats are just as important as militarized threats, and are an essential element in this study. One hypothesis of this study is that dominant states will react differently to a non-militarized threat than they would to a militarized threat. We might ask, for example, "How did the United States react to a militarized threat (the Soviet Union) in contrast to a non-militarized threat (Japan) after World War II?" We might also ask, "Was the nature of the threat the key element in the foreign policy outcomes of the United Sates in these cases?" This study answers these questions.

\section{International Systems Theory and Preventive War}

Now that we have highlighted the distinction between prevention and preemption, we can explore the evolution of preventive action itself. The origin of prevention lies in antiquity and can be traced back to at least Thucydides and his study of the sources of the Peloponnesian War. He notes, "The growth of the power of Athens, and the alarm which this inspired in Sparta, made war inevitable." ${ }^{\prime 8}$ Later, he suggests, "Men do not rest content with parrying the attacks of a superior, but often strike the first blow to prevent the attack being made." 9 Though he never uses the term, the conflict between Athens and Sparta as portrayed by Thucydides can be described as a preventive war. The actual term "preventive war" was first used by Thomas Fuller in 1639, in his book The History of the Holy War, while explaining the legality of the Crusades. He suggests, "A preventive war, grounded on a just fear of an invasion... is warranted by reason and the practice of all wise nations...It is the most advised way not to wait for the enemy, but to seek him out in his own country." ${ }^{10}$ The concept of prevention was further articulated by Otto von

\footnotetext{
${ }^{8}$ Robert B. Strassler, ed., The Landmark Thucydides: A Comprehensive Guide to the Peloponnesian War (New York: Touchstone, 1996), 16.

${ }^{9}$ Ibid., 372.

${ }^{10}$ Thomas Fuller, The History of the Holy War (London: William Pickering, 1639/1840), 15-16. For the etymology of the term see the Oxford English Dictionary (Online Version) (Second) (Oxford University Press, 1989); available
} 
Bismarck who suggested that "No government, if it regards war as inevitable even when it does not want it, would be so foolish as to leave to the enemy the choice of time and occasion and to wait for the moment which is most convenient for the enemy." contemporaneously by the Bush administration in "The National Security Strategy of the United States" in which President Bush, discussing terrorism, stated, "America will act against such emerging threats before they are fully formed." ${ }^{12}$ The idea of prevention, in an international relations context, is thus a well-established concept.

\section{Balance of Power Theory and War}

Prevention as a general theory of international relations is a much more recent phenomenon and is a product of some of the most important research in the field over the past fifty years. This research has yielded a rich theoretical literature dealing primarily with systemic and structural variables. The theory of preventive war in the post World War II era has been a topic of interest for many scholars including Hans Morgenthau (1948, 1967), A.F.K. Organski (1958, 1968), and Robert Gilpin (1981). Morgenthau, Organski, and Gilpin address the issue of prevention as part of a larger framework designed to explore international politics or causes of war in general and not specifically preventive war. Furthermore, Morgenthau and Organski are primarily concerned with power; whether in the former's case of a balance of power or in the latter's case of a hierarchy of power.

from http://80-

dictionary.oed.com.www.libproxy.wvu.edu/cgi/entry/00188322/00188322se4?single=1\&query_type=word\&queryw ord=preventive+war\&edition=2e\&first=1\&max_to_show=10\&hilite=00188322se4 .

${ }^{11}$ Bismarck was ambivalent about his feelings regarding preventive war for he also stated, "Preventive war is like suicide from fear of death.”

${ }^{12}$ Introductory letter, signed by President George W. Bush. "The National Security Strategy of the United States," (2002). 
Morgenthau, in Politics Among Nations, discusses prevention only in passing in the development of his theory of international relations, but he suggests preventive war is a necessary means of maintaining equilibrium in the international system:

Since in a balance of power system all nations live in constant fear lest their rivals deprive them, at the first opportune moment, of their power position, all nations have a vital interest in anticipating such a development and doing unto the others what they do not want the others to do unto them.... Preventive war, however abhorred in diplomatic language and abhorrent to democratic public opinion, is in fact a natural outgrowth of the balance of power. ${ }^{13}$

Morgenthau suggests in his balance of power theory, that war is least likely in an

international system in which multiple states have roughly equal amounts of power. According to this theory, if states are able to balance against an aggressor, either through their own power or with the combined power of allies, no state is likely to initiate war since it would be able to see that the balance of power would shift against it. In such a system, aggression is futile because such action would result in a counterbalance that would defeat any aggressor and restore balance to the system. Traditional balance of power theory thus paints a picture of a relatively static system. $^{14}$

More recently, Paul Kennedy and John Mearsheimer have added an element of dynamism to balance of power theory. Kennedy, in The Rise and Fall of the Great Powers, views the international system through an economic lens and suggests that states grow at different rates. He argues that the international system is essentially one of shifting power, based largely on economic forces. According to Kennedy, economic power shifts from the most powerful states to rising challengers. He suggests that the nation most likely to gain military power is that nation that is most able to gain economic power. Essentially, he argues that large

\footnotetext{
${ }^{13}$ Hans J. Morgenthau, Politics among Nations: The Struggle for Power and Peace, 4th ed. (New York: Knopf, 1967), 202-03.

${ }^{14}$ For additional balance of power perspectives, see works by Morton Kaplan, Karl Deutsch and J. David Singer, Kenneth Waltz, Ludwig Dehio, and Henry Kissinger.
} 
and powerful militaries require massive amounts of financial capital. He also suggests that as powers grow, they tend to overreach their natural abilities. It is this overreach that strains a countries military and economic capacities and eventually forces great powers to pull back from their goals of global dominance. ${ }^{15}$

John Mearsheimer, in The Tragedy of Great Power Politics, focuses much more on military power. While he does not directly address the issue of preventive war, his theory of offensive realism implies that preventive war, or at least some form of preventive action, should be a normal tool of statecraft. He suggests that domestic politics and governmental structure play a negligible role in determining whether a state will initiate war against another state. Instead, he argues it is the structure of the international system that determines the level of war proneness. He argues that major variations of balance in the international system can affect a nation's calculations regarding the efficacy of war. He suggests that multipolar systems with a potential hegemon are the most war prone, with multipolar systems of roughly equal states as second most war prone, and bipolar systems as the least war prone. According to offensive realism, a potential hegemon in a multipolar system will likely initiate war to become a true hegemon. Implicit in this argument is that the potential hegemon, or a true hegemon if it reaches that status, would also initiate preventive war against any challengers. Like Kennedy, Mearsheimer suggests that major powers jockey for position in the international system. ${ }^{16}$

\section{Power Transition Theory and the Hierarchy of the International System}

Not all international relations scholars, however, agree with the balance of power theorists' portrayal of the international system, nor their conclusions regarding preventive war. In

\footnotetext{
${ }^{15}$ Paul Kennedy, The Rise and Fall of the Great Powers: Economic Change and Military Conflict from 1500 to 2000 (New York: Vintage Books, 1987).

${ }^{16}$ John J. Mearsheimer, The Tragedy of Great Power Politics (New York: W.W. Norton \& Company, 2001).
} 
particular, Organski, in World Politics, criticizes Morgenthau on the basis that he does not take into account the fundamental problem of differential rates of growth. In response, Organski develops his own theory of international relations - power transition theory. ${ }^{17}$ Organski examines preventive war in more depth than Morgenthau does; but it is still a tangent in a larger theoretical framework. Power transition theorists see an international system that is hierarchical in nature with a "dominant power" at the top of the hierarchy. ${ }^{18}$ They suggest that a powerful state — once it ascends to the dominant position — configures the international system to serve its own long-term interests. Kugler and Organski $(1980,1989)$ argue that the maximization of net gains is the goal of the dominant power. ${ }^{19}$ Beneath this dominant power are other "great" or "major" powers that have a significant proportion of the power of the dominant state. The great powers "share in the allocation of resources and...help maintain the international system."20 Below the great powers are "middle powers" and "small" or "minor" powers that, though they might be dissatisfied with the status quo, do not play an important role in the international

\footnotetext{
${ }^{17}$ Power transition theorists were examining the causes of differential rates of growth before authors like Kennedy and Mearsheimer incorporated those concepts into balance of power theory. Power transition theorists continue to be relevant because they have diversified their research while focusing increasing attention on the internal aspects of power. See Jacek Kugler and Douglas Lemke, "The Power Transition Research Program: Assessing Theoretical and Empirical Advances," in Handbook of War Studies II, ed. Manus I. Midlarsky (Ann Arbor: The University of Michigan Press, 2000). See also Ronald L. Tammen et al., Power Transitions: Strategies for the 21st Century (New York: Chatham House Publishers, 2000).

${ }^{18}$ Power transition theorists do not refer to this dominant power as a "hegemon." Power transition theorists have a rather narrow conceptualization of a hegemon, which they define as a nation that can "single-handedly control the actions of other powerful nations." This is different from simply requiring a hegemon to have a preponderance of power. As a consequence of such a restrictive definition, it is unclear whether there has ever been a true hegemon in the modern international system. Therefore, power transition theorists speak in terms of a "dominant power." See Ronald L. Tamen et al., Power Transitions: Strategies for the 21 st Century (New York and London: Chatham House Publishers, Seven Bridges Press, LLC, 2000).

${ }^{19}$ Jacek Kugler and A.F.K. Organski, "The Power Transition: A Retrospective and Prospective Evaluation," in Handbook of War Studies, ed. Manus I. Midlarsky (Boston: Unwin Hyman, 1989). See also A.F.K. Organski and Jacek Kugler, The War Ledger (Chicago and London: The University of Chicago Press, 1980). While the dominant state can configure the international system to favor its own domestic structure, in most cases it cannot prevent states with different internal structures from gaining power. Challenger states gain power even though they must do so in an international environment that does not favor them. See Kugler and Lemke, "The Power Transition Research Program: Assessing Theoretical and Empirical Advances," 130-31.

${ }^{20}$ Tammen et al., Power Transitions: Strategies for the 21 st Century, 6.
} 
system. However, they may play a supporting role in any struggle between the dominant power and a dissatisfied major power. ${ }^{21}$

In contrast to balance of power theory, power transition theory suggests that confrontation is most likely when the dominant power and an unsatisfied state are roughly equal in power. Such a rough equilibrium of power comes to pass because the dominant state, which has already gone through industrialization with the accompanying growth spurt in such determinants of power as population, political efficiency, and economic development, has since slowed in its overall growth. The rapidly rising challenger, however, is going through its own power transition, which brings it closer to the power of the dominant state and may catapult it ahead of the dominant. This view of dynamic change within the state that results in a new distribution of power is in contrast to balance of power theorists who suggest that the main mechanism for a state to increase its power is through increasing armaments, conquering new territory, or winning new allies. ${ }^{22}$

It is also this element of dynamic change and power differentials within the state that places power transition at the heart of the preventive war literature. Though power transition theory predicts that in most cases it is the challenger who starts wars in an attempt to change the status quo, the theory does contribute to the development of preventive war theory by suggesting that there have been instances in which the dominant state attempts to halt a challenger's rise using preventive war. Organski addresses this issue by attempting to answer the broader question of why power differentials sometimes result in war, and at other times do not. He suggests that war is likely if the following conditions are present:

1) If the challenger is of such a size that at its peak it will roughly equal the dominant nation in power

\footnotetext{
${ }^{21}$ Ibid., 7.

${ }^{22}$ A.F.K. Organski, World Politics, 2nd ed. (New York: Knopf, 1968), 288.
} 
2) If the rise of the challenger is rapid

3) If the dominant nation is inflexible in its policies

4) If there is no tradition of friendship between the dominant nation and the challenger

5) If the challenger sets out to replace the existing international order with a competitive order of its own ${ }^{23}$

Power transition theory predicts that if the dominant power is going to initiate a preventive war, it is likely to do so in the beginning stages of the power transition when its military power is at its zenith vis-à-vis the challenger. It will do so because the leadership of the dominant state will realize that the longer it waits, the less its chances of winning a conflict. In fact, by the time the challenger enters the power transition, the dominant state may fear that it will lose its power to control its own foreign policy. Such fear may spark a preventive war against the challenger. ${ }^{24}$ Power transition theory's major contribution to a strong theory of preventive action lies mainly in its emphasis on the internal growth of states. It provides a mechanism by which power transformations occur, without which it would be difficult to discuss the preventive motivation.

\footnotetext{
${ }^{23}$ Ibid., 372-75.

${ }^{24}$ While much of the power transition theory literature deals with prevention only tangentially, the following works are valuable extensions of the theory: Kelly M. Kadera, The Power-Conflict Story: A Dynamic Model of Interstate Rivalry (Ann Arbor: The University of Michigan Press, 2001); A.F.K. Organski and Jacek Kugler, "The Costs of Major Wars: The Phoenix Factor," in The Scientific Study of Peace and War: A Text Reader, eds. John A. Vasquez and Marie T. Henehan (Lanham: Lexington Books, 1992, 1999); Jacek Kugler and A.F.K. Organski, "The Power Transition: A Retrospective and Prospective Evaluation," in Handbook of War Studies, ed. Manus I. Midlarsky (Boston: Unwin Hyman, 1989); Jacek Kugler and Douglas Lemke, "The Power Transition Research Program: Assessing Theoretical and Empirical Advances," in Handbook of War Studies II, ed. Manus I. Midlarsky, (Ann Arbor: The University of Michigan Press, 2000); Ronald L. Tammen, et. al., Power Transitions: Strategies for the $21^{\text {st }}$ Century (New York: Chatham House Publishers, 2000); Jacek Kugler and Douglas Lemke, eds., Parity and War: Evaluations and Extensions of The War Ledger (Ann Arbor: The University of Michigan Press, 1996); Jonathan M. DiCicco and Jack S. Levy, "The Power Transition Research Program," in Colin Elman and Miriam Fendius Elman, eds., Progress in International Relations Theory: Appraising the Field (The MIT Press, 2003), 10957; A.F.K. Organski and Jacek Kugler, The War Ledger (Chicago: The University of Chicago Press, 1980).
} 


\section{$\underline{\text { Hegemonic Stability Theory and Prestige }}$}

Robert Gilpin, in War \& Change In World Politics, further develops the concept of prevention by using power transition theory's hierarchy, but at the same time introducing the element of prestige. He suggests that a preventive war waged by a declining dominant power against a rising challenger may be the "most attractive response" available to the dominant state. ${ }^{25}$ Contrary to balance of power and power transition theories, however, Gilpin argues that prestige and not power may be the most important aspect of the international hierarchy. Gilpin segregates power and prestige as follows: "Whereas power refers to the economic, military, and related capabilities of a state, prestige refers primarily to the perceptions of other states with respect to a state's capacities and its ability and willingness to exercise its power." 26 The prestige of a state rests on its ability and willingness to use military and non-military force to achieve its objectives. In other words, are the promises and threats of a state credible? A state that is powerful — and willing and able to use that power-will have more prestige than a state that is weak, or is powerful but unwilling to use its power. Gilpin goes so far as to argue that the international system is actually based on prestige, not power. $^{27}$

\section{Perception and Preventive War}

Jack Levy (1987) contributes to the evolution of preventive war theory by suggesting that perception is the key to understanding why preventive actions sometime occur and at other times do not. As I have noted above, Levy develops his concept of "preventive motivation," which revolves around the dominant state's perception that it is declining and the fear of the consequences of that decline. He was also the first scholar to pursue a research program that

\footnotetext{
${ }^{25}$ Robert Gilpin, War \& Change in World Politics (New York: Cambridge University Press, 1981), $191,201$.

${ }^{26}$ Ibid., 31.

${ }^{27}$ Robert Gilpin, War and Change in World Politics (Cambridge University Press, 1981), 31.
} 
isolated preventive war from more general theories of international relations or world politics.

Levy suggests that the preventive motivation is best viewed as an intervening variable between a power shift and the decision to initiate war. He attempts to understand how preventive motivation fits in with other variables in determining whether a state in relative decline will initiate war against a rising challenger. He incorporates elements of prospect theory, suggesting that states become risk acceptant when faced with losses, and argues that this fact goes a long way in explaining why declining states are likely to initiate preventive war. ${ }^{28}$

In an update of the 1987 article, Levy and Joseph Gochal (2004), suggest that preventive war initiated by a declining state has been a "fairly common" event in history. In their view, states in relative decline, who anticipate that a rising adversary will "either surpass it in military strength or cross a critical threshold of military capabilities," have frequently launched preventive wars. ${ }^{29}$ Levy and Gochal argue that dominant powers may also be motivated to take preventive action if they think the status quo will get worse for them if the rising challenger is allowed to continue its ascendancy. This might reflect a general fear of a loss of bargaining power or fear of what the rising state might do once it gains a certain level of power, even if war is not necessarily seen as inevitable. ${ }^{30}$ For example, the globally dominant state, which is also the major power in a specific region, will not want to be replaced at the regional level by a new regional power. In such a scenario, if it is clear that the global dominant power will remain dominant on the world stage as a whole, but that it will be replaced within a particular region as the dominant power, the global dominant state might strike at the challenging regional state. The rising challenger does not necessarily need to have the potential of matching the dominant power

\footnotetext{
${ }^{28}$ Levy, "Declining Power and the Preventive Motivation for War."

${ }^{29}$ Jack S. Levy and Joseph R. Gochal, "When Do Democracies Fight "Preventive Wars"?: Theory and Evidence" (paper presented at the Annual Meeting of the International Studies Association, Montreal, Canada, March 17-20 2004).

${ }^{30}$ Ibid.
} 
in every aspect to be threatening. ${ }^{31}$ Such a situation may be enough to spark a dominant initiated preventive action. ${ }^{32}$ Similarly, the threat that an adversary may cross some threshold of military technological capacity—such as attaining weapons of mass destruction — may be enough to prompt a dominant state to initiate preventive action. ${ }^{33}$

\section{Empirical Work}

A number of scholars have utilized preventive war theory to explain empirical cases. For example, Richard Ned Lebow, Stephen Van Evera, and Jack Snyder, among others, have used preventive war theory to explore the origins of World War I. ${ }^{34}$ In these cases, they have used the theory to examine whether challengers take advantage of opportunities that arise from power shifts, or whether dominant states take advantage of "windows of opportunity" to strike at challengers that have not yet reached their full potential. ${ }^{35}$ There have also been many quantitative tests for balance of power theory and power transition theory. Some of these tests shed light on the utility of a theory of preventive war. ${ }^{36}$

\footnotetext{
${ }^{31}$ This is in contrast to Organski's points 1 and 5. See pg. 10.

${ }^{32}$ For a discussion about potential regional hegemons see John J. Mearsheimer, The Tragedy of Great Power Politics (New York and London: W. W. Norton \& Company, 2001).

${ }^{33}$ Levy and Gochal, "When Do Democracies Fight "Preventive Wars"?: Theory and Evidence".

${ }^{34}$ See Richard Ned Lebow, Between Peace and War: The Nature of International Crisis (Baltimore and London: The Johns Hopkins University Press, 1981).; Richard Ned Lebow, "Windows of Opportunity: Do States Jump through Them?," International Security 9, no. 1 (1984).; Jack L. Snyder, "Perceptions of the Security Dilemma in 1914," in Psychology and Deterrence, ed. Robert Jervis, Richard Ned Lebow, and Janice Gross Stein (Baltimore: The Johns Hopkins University Press, 1985).; Jack Snyder, The Ideology of the Offensive: Military Decision Making and the Disasters of 1914, ed. Robert Jervis, Robert J. Art, and Stephen M. Walt, Cornell Studies in Security Affairs (Ithaca and London: Cornell University Press, 1984).; Stephen Van Evera, "The Cult of the Offensive and the Origins of World War I," International Security 9, no. Summer (1984).

${ }^{35}$ See Lebow, "Windows of Opportunity: Do States Jump through Them?." for a counterargument as to whether states really take advantage of temporary military superiority. Lebow suggests that leaders are constrained by psychological factors and do not jump through windows of opportunity. For an extensive discussion of "windows" see Stephen Van Evera, Causes of War: Power and the Roots of Conflict (Ithaca and London: Cornell University Press, 1999), especially chapter four.

${ }^{36}$ See among others Zeev Maoz, Paths to Conflict (Boulder, CO: Westview, 1982), chaps. 4-6.; Emerson M. S. Niou and Peter C. Ordeshook, "Preventive War and the Balance of Power: A Game Theoretic Approach," Journal of Conflict Resolution 31, no. September (1987).; Tamen et al., Power Transitions: Strategies for the 21st Century.; Woosang Kim and James D. Morrow, "When Do Power Shifts Lead to War?," American Journal of Political
} 
Dale Copeland, in his important book The Origins of Major War, contributes to the development of preventive war theory by arguing that, in contrast to power transition and hegemonic stability theories, it is not the rising state but the dominant state that initiates war. He suggests that balance of power, power transition, and hegemonic stability theories are all inadequate in explaining under what conditions a declining state is likely to engage in preventive war. He argues that while many scholars recognize that preventive wars are a significant problem in history, they have failed to develop an adequate theoretical basis explaining the conditions under which preventive militarized action is initiated. ${ }^{37} \mathrm{He}$ also argues that, contrary to power transition and hegemonic stability theory, most of the major wars in world history have been started by the declining dominant power. Furthermore, he notes, even if the dominant power did not start a war, it often engaged in risk acceptant behavior that brought about crises that raised the chances of war. His "dynamic differentials theory" integrates many of the concepts found in the other theories addressed above. Power differentials, polarity, and fear of decline are brought together under the umbrella of his theory. Furthermore, he takes into account the expected speed, depth, and type of decline being experienced by the dominant power. He grapples with the theoretical puzzle of preventive action by developing a rigorous theory that focuses mainly on structural aspects of the system, but also includes some elements of the domestic sphere. Nonetheless, he takes a much more deterministic approach to the subject than does Levy. In a sense, Copeland returns to the traditional approaches of Gilpin and Organski in that he focuses mainly on material and systemic determinants of power. ${ }^{38}$

Science 36, no. 4 (1992); ; Daniel S. Geller, "Status Quo Orientation, Capabilities, and Patterns of War Initiation in Dyadic Rivalries," Conflict Management and Peace Science 18, no. 1 (2000).

${ }^{37}$ Dale C. Copeland, The Origins of Major War, ed. Robert J. Art, Robert Jervis, and Stephen M. Walt, Cornell Studies in Security Affairs (Ithaca, New York: Cornell University Press, 2000), 12.

${ }^{38}$ Ibid. 
One of Copeland's most significant contributions is his acknowledgement that preventive action need not necessarily result in armed conflict. He suggests that a declining state becomes risk acceptant and is willing to initiate a crisis if it believes that by doing so it might stem relative decline. A declining state is willing to do this because it does not fear war in the short term. In Copeland's view, if a state believes war is likely or inevitable in the future, and that such a war will be fought under increasingly worsening conditions, it has nothing to lose by initiating a crisis in the short term. According to this logic, if the crisis is managed successfully, relative decline will be slowed or reversed. If the crisis spirals out of control, then a war will be fought under the best possible conditions. Doing nothing will result in further deterioration of the declining state's power position. Copeland, however, does not go into detail about what types of preventive action a declining state might initiate. Other than initiating crises in order to forestall relative decline, he does not explore the types of preventive action a state might initiate. ${ }^{39}$

\section{State Level Theories and Preventive War}

As is evident, most of the literature dealing with preventive war does not take more than a cursory look beyond systemic factors. However, in recent years a number of scholars have begun to examine the topic of prevention in terms of domestic factors. These scholars have focused on such wide-ranging topics as the effect of ruling groups, the internal structure of states, and what role belief systems play in preventive war decisions. Perspectives that focus on the state level allow us to move beyond systemic explanations that quite often fail to explain why a state sometimes does not choose to engage in preventive war.

Randall Schweller was one of the first scholars to examine some of these domestic factors. He is interested in the domestic political structure of states and asks the question, "Do

\footnotetext{
${ }^{39}$ Ibid.
} 
democracies fight preventive wars?" He also wonders why "some power shifts result in preventive war while others do not." Schweller argues that it is the internal domestic structurewhether democratic or not - that determines how a declining dominant power responds to a rising challenger. He concludes that when faced with a democratic rising challenger, democracies do not initiate preventive war, but instead accommodate the challenger. When it comes to non-democratic challengers, however, democratic states attempt to form defensive alliance systems. Also of interest, though, is that he leaves open the possibility that a democracy may initiate preventive war against a non-democratic challenger if the dominant democratic state believes that such a war would not be long or costly. Meanwhile, non-democratic states, when faced with a challenger (whether democratic or not), will either form a defensive alliance or will initiate preventive war. Accommodation is not in their nature. In all, Schweller suggests that there are four possible responses by a dominant state facing a challenger: 1) accommodation, 2) internal balancing — which is difficult for democracies because of the costs involved in building up military power, 3) alliance formation, and 4) preventive war. ${ }^{40}$ In sum, Schweller's article is important both because he examines the internal structure of states, and because he suggests a range of responses by the dominant state.

Jack Snyder, in The Myths of Empire, contributes to the literature on domestic factors of preventive war by examining the internal political dynamics of rising powers, as well as material components of power. The essence of Snyder's arguments is that the origin of a state's foreign policy is not the external environment, but the domestic one and the structures that develop within the domestic realm. This is not to say that events and structures in the international system do not play a part in shaping a nation's foreign policy, but he suggests that the key ingredient in

\footnotetext{
${ }^{40}$ Randall L. Schweller, "Domestic Structure and Preventive War: Are Democracies More Pacific?," World Politics 44, no. 2 (1992).
} 
understanding the foreign policy is domestic affairs and structures. Snyder also suggests that within the domestic sphere, myths of bandwagoning and the paper tiger can arise. These myths, if not counterbalanced by a more rational system of conceptualizations of the international system, can lead a state to overreach. This imperial overreach, in turn, can lead to war and the eventual contraction or destruction of the state.

Though he is largely interested in rising powers, he reiterates the argument that a state is tempted to engage in preventive action if its chances of winning victory in a later war are less than its chances of winning a war now. Other considerations that must be examined, according to Snyder, include the domestic political costs and operational disadvantages of being the aggressor. Furthermore, the stronger state must look at the alternative of the costs of appeasing the rising power. Snyder also points out that leaders calculate both short and long-term shifts in power and resources. If the stronger state perceives the rising state as a future threat that has not fully developed or mobilized its war making capabilities, it might be inclined to attack sooner rather than later. ${ }^{41}$

Snyder is also interested in how states develop and the role of elites in that development. For example, he examines development in Germany and Japan prior to the Second World War. In both of these cases, Snyder suggests that their late industrial development allowed a narrow number of powerful elite groups to set the strategic agenda for the countries. These elite groups were tied closely with the military and the military had a strong influence on the foreign policy of both countries. The power elites and the military had no real checks on their power. Instead, they would work together, in what he terms "logrolling," which allowed each interest group to achieve their main goals, but inevitably pushed their states into empire and overextension.

\footnotetext{
${ }^{41}$ Jack Snyder, Myths of Empire: Domestic Politics and International Ambition, ed. Robert Jervis, Robert J. Art, and Stephen M. Walt, Cornell Studies in Security Affairs (Ithaca, New York: Cornell University Press, 1991), 25-26, 80.
} 
Furthermore, he suggests that because of their late industrial development and the concentration of power within a limited number of elite groups, democracy never had a chance to develop. Snyder compares this lack of democracy to Britain, which developed earlier and along more democratic lines. He demonstrates how democratic institutions prevented strong military elites from hijacking British foreign policy. ${ }^{42}$

Charles Kupchan is perhaps the leading scholar on internal elements dealing with preventive war. In his The Vulnerability of Empire, he examines elite beliefs and the rise of hardliners, domestic politics, and options of the declining state. Kupchan suggests that both military and civilian leaders have an incentive to take hard-line stances. However, as the ill effects of hard-line policies mount, elites begin to realize that their policies are coming to jeopardize the security of their state. After a certain time lag, they come to appreciate that their beliefs are inconsistent with incoming information. Elite beliefs are fairly sensitive to incoming and disconfirming information, and decision makers eventually become aware of the need to adjust grand strategy. Unfortunately, elite beliefs, which are relatively malleable, run into public opinion, or what Kupchan calls "strategic culture," which is more resistant to incoming information and to change. ${ }^{43}$ Kupchan demonstrates how hard-liners can become entrapped by the strategic culture which they, at least in part, helped manufacture. He suggests that even though strategic images may be created primarily for public consumption, they gradually spread through the elite community. Over time, individual members of the elite community come to believe in the strategic images that they repeatedly articulate before the public. This is especially true when decision makers pursue policies consistent with the images they are propagating. In essence, they come to believe their own rhetoric, and internalize the images they are producing.

\footnotetext{
${ }^{42}$ Ibid.

${ }^{43}$ Charles A. Kupchan, The Vulnerability of Empire (Ithaca and London: Cornell University Press, 1994), 89-90.
} 
New members of the elite community, and those not in the inner circle, unaware that prevailing strategic conceptions were originally crafted for propaganda purposes, become indoctrinated in the strategic culture. Over the longer term, elites may find it costly in political terms to refute precisely those images that they had previously been championing. Because strategic culture can infuse the elite community and its institutions with powerful images that override strategic logic, elites may not even accept that they must reverse course despite incoming information pointing to the need to do so. Furthermore, because elite beliefs adapt faster to new information than strategic culture, the same images that once shaped public opinion and empowered decision makers eventually can come to constrain them. ${ }^{44}$ All of these factors have important implications when it comes to the decision of whether to initiate preventive action.

Kupchan's emphasis on "vulnerability" is also of importance when discussing the probability of preventive war. Kupchan suggests, "Should elites believe that conflict with the rising state is unavoidable, they may even resort to preventive war in order to defeat the adversary while they still have the capability to do so." ${ }^{.5}$ In Kupchan's view, high vulnerability means, "elites operate under conditions of strategic deficiency. They calculate that their own resources and those of their allies are insufficient to enable them to prevail against the likely adversary or adversarial coalition." Because of this, declining states will attempt to avoid war, if possible. They will do so, even if it means making concessions to the rising challenger. He suggests, "It might be possible to avoid conflict altogether by meeting the demands of the adversary. At a minimum, accommodation will postpone conflict and buy time for the defender to seek added resources and improve the military balance. ${ }^{46}$ Kupchan thus runs counter to the rest of the preventive war literature by suggesting that time is on the side of the declining state.

\footnotetext{
${ }^{44}$ Ibid., 15, fn. 68, 72, 90-98.

${ }^{45}$ Ibid., fn. 68,72 .

${ }^{46}$ Ibid., 73 .
} 
He suggests that adding allies or military resources over the long term will benefit the decliner. On the other hand, he suggests time is not on the challenger's side and thus provides an incentive for an attack against the dominant state. Despite these controversial hypotheses regarding which side is favored by the passage of time, Kupchan's insight into the domestic sphere is extremely valuable.

\section{Conclusion - Expanding the Concept and Examining Domestic Factors}

In sum, much of the past fifty years of international relations literature has dealt with preventive war directly or indirectly. However, there has been much discussion of whether the dominant or challenger state in a given dyad is most likely to initiate war. There are also serious deficiencies in much of the literature, though some scholars have begun to address some of these issues. Of particular importance are the issues of degrees of preventive action and the determinants of that action.

On the first front, most scholars have treated the issue of prevention as an either-or proposition: either states initiate war, or they do not. I suggest that this is an overly simplistic view of a complex subject. Like Schweller, and to a lesser extent Copeland, I suggest that there is a range of possible responses by the declining power. By looking at a variety of forms prevention may take, we can better understand the utility of the concept and build a more refined theory of preventive action. On the second front, by examining more closely domestic factors such as elite belief systems, domestic political constraints, and the choices elites make; we can better understand the dynamics of the preventive motivation. We may then be in a position to explain better why power shifts sometimes lead to war and other times do not. 
All scholars stand on the shoulders of those who have come before us, and I am no different. On the one hand, this research fits in with that of scholars such as Levy and Copeland who suggest that it is the dominant state that is likely to initiate preventive action. On the other hand, I join scholars like Schweller, Snyder, and Kupchan by emphasizing domestic level factors. I also agree with Gilpin that prestige plays a part in explaining why states act the way they do, and I explore this element in my case studies. I also explore Levy's ideas of decision makers' perceptions regarding the domestic atmosphere, the international system, and the adversary. I use Snyder's insights about domestic politics and the literature on belief systems, as well as Kupchan's concept of strategic culture, to shed light on preventive action initiated by dominant powers. This study, then, contributes to the literature by recognizing a wider range of preventive actions and by focusing more closely than others on domestic factors. ${ }^{47}$

\footnotetext{
${ }^{47}$ I have not included a discussion of two other schools of thought that have elements of preventive war theory ingrained in their structure. Long cycle theory and power cycle theory are offshoots of power transition theory and hegemonic stability theory, and do not add in a substantial way to the literature reviewed here. Nonetheless, any study of preventive action must at least acknowledge the existence of these other bodies of literature. For a review of power cycle theory see Charles F. Doran, "Confronting the Principles of the Power Cycle: Changing Systems Structure, Expectations, and War," in Handbook of War Studies II ed. Manus I. Midlarsky (Ann Arbor: The University of Michigan Press, 2000). For a review of the long cycle see George Modelski and William R. Thompson, "Long Cycles and Global War," in Manus I. Midlarsky, ed., Handbook of War Studies (Boston: Unwin Hyman, 1989), p. 23-54.
} 


\section{Chapter Three \\ The Domestic Politics Model of Prevention (DPMP)}

As mentioned above, I am arguing that preventive action can take different forms, from diplomatic actions, to sanctions and embargoes, to one-time military strikes, to general war. I suggest that our traditional instruments for detecting preventive action have not been sensitive enough. By looking only for preventive war, most scholars have failed to see other forms of preventive action. Even those scholars who have acknowledged different types of preventive action have not sufficiently developed a typological theory of the phenomenon. The theoretical puzzle that has not been addressed in the literature is why a particular preventive action takes the form it does. Why in one case is an economic and military embargo levied, while in another case an invasion initiated?

My answer is that the form preventive action takes is largely determined by domestic factors. Despite the contributions of hegemonic stability theory and power transition theory, the preventive war literature has essentially disregarded non-structural aspects and, with the exception of scholars such as Copeland and Schweller, has largely ignored variation in the scope of preventive action. My Domestic Politics Model of Prevention (DPMP), as outlined below, addresses the shortcomings of systemic structural theories by suggesting that domestic factors are largely responsible for determining when a state will initiate a preventive war, and when it will initiate less extreme forms of preventive action. In developing hypotheses that posit answers to this question, and testing those hypotheses, I develop a rigorous first cut at a typological theory of preventive action that explains the form preventive action ultimately takes. I create a model of preventive action, which demonstrates the utility of a broader conceptualization. This project contributes to the intellectual discussion by developing a model of preventive action grounded in domestic level factors. In so doing, I utilize some basic assumptions and findings of 
prospect theory. More fundamentally, I use the method of structured, focused comparison to examine the interaction of domestic elements as well as systemic phenomena, and how that interaction shapes the form preventive action takes. However, by using a limited number of historical case studies I do not anticipate finding definitive proof of my hypotheses. Instead, I suggest that if I find evidence to support my concepts, it will provide an incentive for continued research in an area that has been underdeveloped by scholars.

\section{Assumptions of the DPMP: Prospect Theory}

Prospect theory provides a basis for understanding how states in relative decline might respond to rising challengers. Prospect theory suggests that actors are more fearful of losing what they have — what is termed loss aversion — than they are hopeful of gains. ${ }^{1}$ Actors will take risks to preserve what they have, whereas they will not take a similar risk to gain a similar objective. Prospect theory demonstrates that actors tend to overvalue what they have, and tend to favor the status quo. In other words, states will fight to protect what they have, whereas they may be less willing to fight to achieve conquest. ${ }^{2}$ Accordingly, if there is a possibility that taking preventive action will result in a loss, a state should not engage in such activity. However, if it is probable that a loss will be suffered if nothing is done, the state will take preventive action. Similarly, if it is likely that a state's situation vis-à-vis another state will only worsen if no action is taken, it will likely take preventive action to slow or stop the deterioration. ${ }^{3}$ In short, declining states are security maximizers while rising challengers are "cautious" power maximizers. These aspects of prospect theory are integrated into the model as outlined below.

\footnotetext{
${ }^{1}$ Prospect theory is quite complex, and not all elements apply to preventive action. Only the relevant aspects are included here.

${ }^{2}$ Jack S. Levy, "Prospect Theory, Rational Choice, and International Relations," International Studies Quarterly 41 (1997).

${ }^{3}$ Ibid.
} 


\section{Components of the DPMP}

Having briefly examined prospect theory above, it is now possible to develop a model of preventive action focused on domestic factors and the actions of domestic elements-by which I mean elites, decision makers, leaders, ruling coalitions, political opposition, and influential interest groups. I test this model against two other models—one composed of systemic structural causal mechanisms and one composed of domestic structural causal mechanisms. I do this in order to test whether preventive action occurs as suggested by structural theories, or whether a model based on other factors might perform better. I argue that the form preventive action takes is primarily determined by the three causal mechanisms in my model, and that the DPMP will perform better than a purely structural model. ${ }^{4}$

\section{Causal Mechanism 1: Internal Power Constraints}

The first causal mechanism in the DPMP is the level of internal power constraints, measured by whether the state has an offensive or defensive military doctrine. If a state has not prepared for offensive warfare, it cannot initiate militarized preventive action, or at least it would be foolhardy to do so. Defensive military postures, then, act as an internal power constraint on the leadership's ability to exercise this form of preventive action. ${ }^{5}$ However, non-militarized preventive action is still a viable option for a state with a defensive military doctrine.

\footnotetext{
${ }^{4}$ George and Bennett define a causal mechanism as "ultimately unobservable physical, social, or psychological processes through which agents with causal capacities operate, but only in specific contexts or conditions, to transfer energy, information, or matter to other entities. In so doing, the causal agent changes the affected entity's characteristics, capacities, or propensities in ways that persist until subsequent causal mechanisms act upon it." See Alexander L. George and Andrew Bennett, Case Studies and Theory Development in the Social Sciences, Bcsia Studies in International Security (Cambridge, Massachusetts: MIT Press, 2005), 137.

${ }^{5}$ Jack Snyder, The Ideology of the Offensive: Military Decision Making and the Disasters of 1914, ed. Robert Jervis, Robert J. Art, and Stephen M. Walt, Cornell Studies in Security Affairs (Ithaca, New York: Cornell University Press, 1984).
} 
Jack Snyder's study of the role of military doctrine in the outbreak of war in 1914, demonstrates how offensive doctrines are propagated among domestic elites, and the military in particular. ${ }^{6}$ He suggests that France, Germany, and Russia all had offensive strategies that prompted them to initiate war, even though there was real reason to believe that defensive strategies were more prudent. Snyder suggests that organizational biases and doctrinal oversimplification on the part of military planners were the primary sources of offensive doctrines. Snyder finds that institutional bias was greatest when the core values of the organization were threatened. These organizations developed overly offensive doctrines in order to ensure that the institutions were indispensable. ${ }^{7}$

In essence, military planners create offensive doctrines because those doctrines ensure that the military has a mission. This is even more effective when they are able to make the argument that the best defense is a strong offense, meaning that if war becomes inevitable, it is better to be in a position to strike first and win a quick victory than to wait to be attacked and get bogged down in a long defensive struggle. Snyder argues that such simplifications of a complex reality, in which defensive strategies often hold the advantage, introduce biases into strategic analysis. $^{8}$

These biases can manifest themselves in the military doctrines of states. Snyder suggests, "As a rule, the weaker power is usually the defender and the stronger is the attacker. This rule tacitly recognizes the advantages of the defense..." ${ }^{\text {" }}$ When the balance of power is more equal, however, states tend to forget the advantages of defensive strategies. Instead, states look for

\footnotetext{
${ }^{6}$ Ibid.

${ }^{7}$ Ibid., 16.

${ }^{8}$ Ibid., 16-19. Snyder is quite concerned with motivational bias in determining whether offensive strategies are proper given reality. I am much less concerned with the presence of bias. I am not interested in whether a particular policy or doctrine was correct, but whether it led to a particular type of preventive action. Nor am I concerned with the normative issue of how historical actors should have acted, but instead in how they did act.

${ }^{9}$ Ibid., 22.
} 
trends of power shifts and "windows of opportunity" through which they might be able to initiate preventive action. One problem, as noted by Snyder, is that strategists tend to see windows when none exist or overrate their importance. Furthermore, Snyder suggests that a rational calculus can yield an offensive strategy when some or all of the following conditions are met: "(1) the state is expansionist, (2) technology either favors the attacker or at least does not strongly favor the defender, (3) geography does not strongly favor the defender, (4) the military balance is favorable, (5) the anticipated trend of the balance is unfavorable."10

The current project is primarily concerned with Snyder's fourth and fifth conditions. First, I am interested in the actions of the militarily dominant state in a given dyad. Second, if the status quo is seen as getting worse if nothing is done, preventive action is a rational response. In this sense, then, internal power constraints in the form of offensive-defensive military strategies are linked to domestic elements' perceptions about the future. This is an example of the interdependence of the causal mechanisms, and leads one to the conclusion that equifinality is likely in this study. ${ }^{11}$

The real issue regarding internal power constraints for this project is to what extent military doctrines hinder those domestic elements who favor preventive action. I suggest that defensive military doctrines constrain the initiation of militarized preventive action, while such doctrines probably have little or no effect on non-militarized preventive action. I would add just one caveat to this statement. If domestic elements fear a downward spiral from non-militarized preventive action to militarized preventive action, and they recognize that they are particularly weak militarily, they may be constrained even non-militarily. However, this should be a

\footnotetext{
${ }^{10}$ Ibid., 22-24.

${ }^{11}$ For a discussion of equifinality see George and Bennett, Case Studies and Theory Development in the Social Sciences. George and Bennett define equifinality as "many alternative causal paths to the same outcome," 10.
} 
relatively rare phenomenon since I am assuming that the dominant state is superior militarily and in a position to at least defend itself against the rising challenger.

\section{$\underline{\text { Causal Mechanism 2: Domestic Political Constraints }}$}

The second causal mechanism I examine is the level of domestic political constraints, measured by the level of domestic opposition and regime fragmentation. It should be noted that my theory shares certain aspects with Hagan's concepts of domestic political oppositions. ${ }^{12}$ This issue is important in understanding to what extent a given regime is able to pursue its preferred foreign policy. ${ }^{13}$ For the purposes of this study, domestic political constraints play an important role in determining whether domestic elements favoring preventive action will be successful in promoting their foreign policy agenda. As suggested in the opposition and war literature, and as emphasized by Hagan, “domestic political pressures [have been] very much the norm in foreign policy making."14 The dialogue and political struggles between different domestic elements are analyzed in the case studies. We find both cooperation, in the form of logrolling between domestic elements that, though they may otherwise be contentious, share a particular common goal; and conflict, in the form of competition between domestic elements with opposing goals. Ultimately, this dialogue results in a foreign policy that, in part, determines the particular form of preventive action, if any, that is eventually initiated.

\footnotetext{
${ }^{12}$ See Joe D. Hagan, "Oppositions, Ruling Strategies, and the Domestic Road to War: Political Explanations of Foreign Policy and the Great Powers since 1815" (paper presented at the Annual Meeting of the International Studies Association, Montreal, Canada, March 17-20 2004).

${ }^{13}$ Joe D. Hagan, "Domestic Political Regime Change and Foreign Policy Restructuring: A Framework for Comparative Analysis," in Foreign Policy Restructuring: How Governments Respond to Global Change, ed. Jerel A. Rosati, Joe D. Hagan, and Martin W. Sampson, III, Studies in International Relations (Columbia, South Carolina: University of South Carolina Press, 1994).

${ }^{14}$ Hagan, "Oppositions, Ruling Strategies, and the Domestic Road to War: Political Explanations of Foreign Policy and the Great Powers since 1815".
} 
Domestic political opposition external to the regime can also affect foreign policy. Hagan suggests that of particular importance "is the strength and intensity of organized opposition immediate to the regime-i.e., dissenting actors within the ruling party, the legislature, the military, and regional governments. These are arenas for formal opposition to the regime, and the ability of the regime to retain power over the long term necessitates support of these institutions." ${ }^{\prime 15}$ Special interests outside the government may also play an important role in opposing foreign policy initiatives of the ruling regime.

Hagan also suggests that "regime fragmentation" is the primary regime property affecting a leader's ability to initiate a preferred foreign policy. He notes, "This concerns the extent to which the central political leadership has persisting internal political divisions in the form of competing personalities, bureaucracies/institutions, faction, parties, or other kinds of autonomous political groups." ${ }^{16}$ Hagan also suggests that there are five types of regimes, ranging from highly cohesive to highly fragmented. These can be broken down as follows: 1) single party regimes dominated by a single, individual leader; 2) regimes fragmented solely by the existence of established, autonomous political institutions/bureaucracies; 3) regimes controlled by a single party/group which is itself internally divided by established political factions; 4) regimes ruled by a coalition of autonomous political groups in which one actor has clear predominance; and 5) regimes ruled by a coalition in which there is no clear, single dominant actor. ${ }^{17}$

The current study will examine how domestic political constraints shape or distort the foreign policy implementation of the ruling domestic elites in each of my cases. I argue that states characterized by severe domestic political constraints, either because of regime

\footnotetext{
${ }^{15}$ Hagan, "Domestic Political Regime Change and Foreign Policy Restructuring: A Framework for Comparative Analysis," 155.

${ }^{16}$ Ibid., 152.

${ }^{17}$ Ibid., 152-54.
} 
fragmentation or political opposition, will be more acquiescent in the face of decline. States with minimal political constraints will be more likely to initiate militarized preventive action.

\section{Causal Mechanism 3: Ruler Belief Systems}

The third causal mechanism I examine is the belief systems of decision makers. Belief systems manifest themselves by how rulers perceive threats. For this project, I am interested in the rise of hard-liners, and the extent to which they are able to affect national policy. In order to specify whether a regime is hard-line, I use Hagan's typology of regime orientation. Hagan categorizes regimes as moderate, pragmatic, militant, or radical, with hard-liners falling into the last two categories. He suggests that these two political orientations are the most war prone and notes, "Leaders with a militant orientation perceive the international system as so hostile that interaction with adversaries is essentially zero-sum ... Adversaries are viewed as having goals that directly threaten the security, well-being, and international status of one's own nation... Confrontation ... is meant to contain the threat and maintain the credibility of the nation's deterrent." The radical orientation, according to Hagan, is one in which "Leaders . . consider adversaries to be evil actors who have a non-rational aggressiveness grounded in an expansionist ideology, unrestrained nationalism, and/or severe domestic crises." 18

In understanding the importance of hard-liners, it is helpful to understand how they come to play an important role in the decision making process. Vasquez defines hard-liners as “....individuals who have a personal predisposition (due to their beliefs) to adopt a foreign policy that is adamant in not compromising its goals and who argue in favor of the efficacy and

\footnotetext{
${ }^{18}$ Joe D. Hagan, "Domestic Political Systems and War Proneness," Mershon International Studies Review 38 (1994). See also Hagan, "Domestic Political Regime Change and Foreign Policy Restructuring: A Framework for Comparative Analysis."
} 
legitimacy of threats and force. ${ }^{, 19}$ Hard-liners are more willing to take risks than are accommodationists. They are also more nationalistic, hold a militaristic view of the world, are hostile toward and distrustful of other nations, and feel unable to control events. ${ }^{20}$ Vasquez suggests that hard-liners exaggerate the nature of threats in order to gain the support of other domestic elements and the public. He argues, "From the point of view of a decision maker facing a crisis, it is certain that strong actions will be supported domestically, while anything less will be criticized as being soft ... In order to keep domestic support, leaders try to placate hardliners." ${ }^{21}$ Hagan adds to this discussion by suggesting that hard-liners may attempt to confront domestic opposition by amplifying foreign threats. They do this with the intent of diverting attention away from failing domestic policies, shoring up their political base, and mobilizing wider public support. ${ }^{22}$ Hagan further argues that the ruling leadership may employ a strategy of "political accommodation" by incorporating "the preferences expressed by the opposition..." 23 If the opposition is hard-line, this may be another avenue through which they can gain influence. Either of the scenarios, diversionary theory or political accommodation, may help hard-liners come to play an important role in the decision-making process. ${ }^{24}$

Hard-line policy is eventually codified into military doctrine and a set of war plans that can be used when needed. The connection between hard-line policies and the military is an oftenstated relationship in the literature. For example, Scott Sagan argues that military leadership is

\footnotetext{
${ }^{19}$ John A. Vasquez, The War Puzzle, Cambridge Studies in International Relations (New York: Cambridge University Press, 1993), 202.

${ }^{20}$ Ibid., 204-06.

${ }^{21}$ Ibid., 214-15.

${ }^{22}$ Hagan, "Oppositions, Ruling Strategies, and the Domestic Road to War: Political Explanations of Foreign Policy and the Great Powers since 1815".

${ }^{23}$ Ibid.

${ }^{24}$ It should be noted that this project differs from the opposition and war literature in one significant aspect. Whereas the opposition and war literature is primarily concerned with how elites respond to domestic politics, this project is more concerned with how elites respond to shifts or perceived power shifts in the international system. How this perception is translated to the domestic sphere is the primary concern of this project. I am interested in domestic politics to the extent that those politics are shaped by the shift or perceived shift in the international sphere, and how those politics then shape foreign policy.
} 
more predisposed, than is civilian leadership, to viewing militarized preventive action as a viable option. He argues that military leaders are socialized to see war as inevitable in the long run and therefore desirable in the short term if it will result in fewer casualties or more certain victory. They are, he suggests, less likely to seek nonmilitary solutions to international problems. In his view, military leaders prefer offensive strategies to defensive strategies, and would much rather be proactive on the battlefield than reactive. All of these factors, he suggests, should lead military leaders to be in favor of militarized preventive action. ${ }^{25}$

Similarly, Alfred Vagts suggests that military officials are suspicious of an adversary's military capability and have a propensity to see danger as increasing. These calculations tend to produce military solutions that favor the use of militarized preventive action. Civilian leadership, on the other hand, is inclined to view military danger as not necessarily increasing, and subject to neutralization through diplomacy. Vagts argues that civilian decision makers may be reluctant to take any action designed to counter-balance a perceived threat for fear of triggering a war initiated by the adversary. ${ }^{26}$

For this reason, I examine the policy making role of the military in each of my cases, and in those cases where it is extreme, I look for evidence of hard-line policies. In this way, I search for a correlation between the two. Ultimately, I predict that domestic elements that exhibit either militant or radical orientations will advocate militarized preventive action, and the more militant or radical the orientation, the more drastic the recommended action.

\footnotetext{
${ }^{25}$ Scott D. Sagan and Kenneth N. Waltz, The Spread of Nuclear Weapons: A Debate (New York and London: W.W. Norton \& Company, 1995)., 56-57.

${ }^{26}$ Alfred Vagts, Defense and Diplomacy: The Soldier and the Conduct of Foreign Relations (New York: King's Crown Press, 1956), 263. For a dissenting view see Kupchan who suggests that both military and civilian leaders have an incentive to take hard-line stances, Charles A. Kupchan, The Vulnerability of Empire, ed. Robert J. Art, Robert Jervis, and Stephen M. Walt, Cornell Studies in Security Affairs (Ithaca, New York: Cornell University Press, 1994), 83-84.
} 
I also suggest that as domestic elements within the dominant state evaluate a rising power, they go through several phases. These phases are not necessarily sequential and may occur simultaneously. In the first phase, domestic elements perceive some threat, in whatever form, from a rising challenger. I argue that a diligent declining power will monitor all other states to the best of its ability. Domestic elements may come to believe that the status quo will get worse for their state if the rising challenger is allowed to continue its ascendancy. This may be true even if the likelihood of conflict is low. They may perceive that their power and potential is in relative decline vis-à-vis a particular rising challenger. I suggest that a challenge to a state's position in the international hierarchy can be enough to begin moving it down the road to preventive action. Because states are risk acceptant when it comes to possible losses, according to prospect theory — whether those losses are something tangible such as territory or whether they are less tangible such as international ranking or prestige — states will likely engage in preventive action.

In the second phase, domestic elements evaluate the nature of the threat and determine their state's level of vulnerability. By looking at the nature of the threat, domestic elements attempt to determine whether the threat is of a military nature. Kupchan suggests, "Should elites believe that conflict with the rising state is unavoidable, they may even resort to preventive war in order to defeat the adversary while they still have the capability to do so."27 I suggest, however, that countering rising threats does not necessarily mean military action. If conflict is perceived as likely, though the challenger is unlikely to initiate militarized action, nonmilitarized preventive action may be preferred by domestic elements in the dominant state. This is not to say that non-militarized preventive action may not be used against a military threat, or that militarized preventive action may not be used against a non-military threat. I am only

\footnotetext{
${ }^{27}$ Charles A. Kupchan, The Vulnerability of Empire (Ithaca and London: Cornell University Press, 1994), fn. 68, 72.
} 
suggesting that in most cases, military threats will be met with military action while non-military threats will be dealt with in a non-military way.

I suggest that in determining the vulnerability of the state, domestic elements not only look at the current power balance, but also the projected power balance. Even if the current balance is favorable, if the projected balance is unfavorable, there will be a feeling of high vulnerability. ${ }^{28}$ Domestic elements experience feelings of vulnerability if they perceive the future as worse than the present. I assume that the dominant state still has superior power, but is fearful that it will lose that superiority in the future. The level of vulnerability, therefore, refers to the extent of that fear. Feelings of vulnerability increase as the future looks increasingly dim. If domestic elements in the dominant state predict that the status quo will continue to worsen if nothing is done, they will likely push for some type of action. If a challenger state were perceived by the dominant state to be a threat, we would expect the dominant state to entertain the notion of initiating preventive action. ${ }^{29}$ In essence, for the purposes of this research project, the question that must be asked is whether the dominant state perceives a threat, and what form that threat is likely to take.

For instances of non-militarized vulnerability, that is, instances of vulnerability that are deemed by the domestic elements in the dominant state to most likely not result in military

\footnotetext{
${ }^{28}$ In this definition of vulnerability, I differ somewhat from Kupchan. Kupchan implies that vulnerability is determined by perceptions of the balance of power as it currently is. See Kupchan, The Vulnerability of Empire, fn. 23, $15-16$.

${ }^{29}$ Kupchan and I disagree on this point. This disagreement originates in our conceptions of when the status-quo defender is likely to initiate preventive action. I suggest that it will be before it is eclipsed by the challenger, Kupchan suggests that it will not be until the challenger has a power advantage. He suggests, "Elites in a great power at the top of the international hierarchy react to challenges to the status quo; they do not initiate them. Decision makers must therefore be careful to avoid actions that could trigger spirals of hostility and precipitate conflict. Competitive policies risk provoking a war that would likely lead to defeat. Preventive war is not a viable option, and deterrent threats lack credibility...[they wish to avoid war altogether]...Should accommodation fail to satisfy the challenger, the time bought by the initial pursuit of cooperative policies would enable the defender, through mobilization and alliance, to improve the military imbalance...Status quo powers will not initiate conflict unless forced to do so." See Kupchan, The Vulnerability of Empire, 20. I suggest, however, that if war is seen as inevitable, and/or elites in the declining state see further decline as inevitable, delay would be irrational. Nonetheless, non-militarized preventive action is a viable option.
} 
action, my predictions are similar to Kupchan's predictions about low vulnerability. I argue that under such conditions, domestic elites will favor non-militarized preventive action. They will not feel the pressure to engage in military activity, and will not see the need for unnecessarily provocative behavior. Diplomatic and economic incentives will be seen as a first step in reducing threats. Kupchan suggests,

At low levels of vulnerability, elites ... focus on strategic and economic considerations in setting priorities; concern about reputation and resolve is far less prominent ... Elites believe that they have at their disposal the resources necessary to deal with external threats. Strategic sufficiency enables them to respond relatively promptly to rising external dangers ... Elites believe that they will be able to attain their international objectives. Even if war breaks out, elites believe that victory is likely; they are operating in the realm of gains. They will therefore [in accordance with prospect theory] behave in a risk-averse manner and pursue policies that ensure continued strategic sufficiency and...security. ${ }^{30}$

However, my disagreement with Kupchan's interpretation of what constitutes high vulnerability (see footnote 28 ) leads to very different conclusions about what action domestic elements will favor. In Kupchan's view, high vulnerability means that the military balance of power is perceived as having already shifted in favor of the challenger. Because of this, domestic elements in declining states will attempt to avoid war, if possible. They will do so, even if it means making concessions to the rising challenger. He suggests, "It might be possible to avoid conflict altogether by meeting the demands of the adversary. At a minimum, accommodation will postpone conflict and buy time for the defender to seek added resources and improve the military balance." 31

While Kupchan is focused on how domestic elements perceive the current military balance of power for explaining feelings of vulnerability, I suggest that feelings of military vulnerability have a more nebulous origin. In my view, domestic elements feelings of military

\footnotetext{
${ }^{30}$ Kupchan, The Vulnerability of Empire, 67-69, 84-85.

${ }^{31}$ Ibid., 73.
} 
vulnerability stem not only from the current balance of military power as they perceive it, but also from the anticipated balance of military power at some point in the future. If domestic elements feel that they currently enjoy a favorable balance of military power, but that in the future that balance may tip in favor of the challenger, they are likely to experience feelings of high military vulnerability and are more likely to initiate militarized preventive action.

There are several problems with Kupchan's interpretation of high vulnerability. The most serious problem is that he views the balance of power as having already shifted and the challenger as militarily superior to the dominant state. He, however, fails to answer the question of why the dominant state would allow the challenger to gain superiority in the first place, even though he acknowledges that elites have a good understanding of the balance of power. ${ }^{32}$ If that were true, why would elites allow their state to be eclipsed by a threatening challenger? The answer is that they would not. They would take some kind of preventive action in an attempt to stop that from happening. Therefore, Kupchan's premise that the challenger state is dominant is flawed.

Another problem with Kupchan's interpretation of high vulnerability is that he does not address what happens if domestic elements perceive the future as being worse militarily. A related issue is that he does not take into account the likelihood of conflict as perceived by domestic elements. If conflict and decline are seen as inevitable, waiting until one's position is even weaker makes no sense. Kupchan tries to get around this by suggesting that in the time bought through concessions to the challenger, the dominant state might build up or strengthen its

\footnotetext{
${ }^{32}$ Ibid., fn. 22, 15-16, 36.
} 
alliance system. This is unconvincing since the possibility exists that any alliance formed by the declining state could be countered by alliance building on the part of the challenger. ${ }^{33}$

Furthermore, I suggest that domestic elites can feel high vulnerability in either a military or non-military dimension. Domestic elements examine both the nature of the threat, whether military or non-military, and the anticipated balance of power. Level of vulnerability deals with the latter. ${ }^{34}$ In the third phase of evaluating the rising power, conflict (either non-militarized or militarized) may be seen increasingly as inevitable. Preventive action is particularly attractive to domestic elements if conflict with an adversary is seen as highly likely or inevitable. I suggest that the greater the likelihood of future conflict, as perceived by the dominant power, the greater the likelihood that preventive action will be initiated. However, because of the decline of the dominant state which serves as a crisis and the growing fear of inevitable conflict, the likelihood increases that hard-liners with a militant political orientation will become the primary decision makers or have privileged access to decision makers and will become influential in the formation of policy. ${ }^{35}$

As the ill effects of hard-line policies mount, elites may begin to realize that their policies are coming to jeopardize the security of their state. After a certain time lag, they may come to appreciate that their beliefs are inconsistent with incoming information. Elite beliefs are fairly sensitive to incoming and disconfirming information, and decision makers may eventually

\footnotetext{
${ }^{33}$ At any rate, such alliance building by the declining state is included in my model. Alliance building with the primary purpose of containing or deterring the challenger falls in the third category of my typology.

${ }^{34} \mathrm{My}$ thoughts regarding level of vulnerability coincide somewhat with Copeland's ideas about expected depth of decline and perceived inevitability of decline. See Dale C. Copeland, The Origins of Major War, ed. Robert J. Art, Robert Jervis, and Stephen M. Walt, Cornell Studies in Security Affairs (Ithaca, New York: Cornell University Press, 2000), 5.

${ }^{35}$ Also, an important characteristic in this phase is what Snyder calls "blowback," that is hard-liners propagate a vision of an implacable foe, and even if they later come to believe that their hard-line policies are doing more harm than good, they are unable to break free of their own propaganda. In such a case, the masses have adopted the view of the implacable foe, and elites are unable to reform that conceptualization of the enemy. See Jack Snyder, Myths of Empire: Domestic Politics and International Ambition, ed. Robert Jervis, Robert J. Art, and Stephen M. Walt, Cornell Studies in Security Affairs (Ithaca, New York: Cornell University Press, 1991), 41-42.
} 
become aware of the need to adjust grand strategy. ${ }^{36}$ Unfortunately, elite beliefs, which are relatively malleable, run into public opinion, or what Kupchan calls "strategic culture," which is more resistant to incoming information and to change. In fact, Kupchan suggests, "Vivid events, such as war and crisis, can alter strategic culture relatively rapidly. Otherwise, shifts in collective self-image and identity take place much more slowly than shifts in elite beliefs." 37 These domestic elements then may become caught up in their own rhetoric, and may be unable to break free of their self-destructive policies.

The concept of strategic culture is one of Kupchan's more valuable ideas. He defines the concept as:

The set of images that shapes a polity's collective disposition toward the behavior of its state in the international arena. It refers to the realm of national identity and consists of the image and conceptions that determine how the polity understands . . the nation's position in the international hierarchy ... The images that constitute strategic culture manifest themselves in and are propagated by numerous structures and mechanisms such as speeches, governmental institutions, popular literature, educational curricula, and local organizations. Strategic culture ... provides a deeply embedded notion of what constitutes national security. ${ }^{38}$

Kupchan demonstrates how hard-liners can become entrapped by the strategic culture which they, at least in part, helped manufacture. He suggests that even though strategic images may be created primarily for public consumption, they gradually spread through the elite community. Over time, individual members of the elite community come to believe in the strategic images that they repeatedly articulate before the public. This is especially true when decision makers pursue policies consistent with the images they are propagating. In essence, they come to believe their own rhetoric, and internalize the images they are producing. New members of the elite community, and those not in the inner circle, unaware that prevailing strategic

\footnotetext{
${ }^{36}$ Kupchan, The Vulnerability of Empire, 15, 89-90.

${ }^{37}$ Ibid., 89-90.

${ }^{38}$ Ibid., 88-89.
} 
conceptions were originally crafted for propaganda purposes, become indoctrinated in the strategic culture.

Over the longer term, elites may find it costly in political terms to refute precisely those images that they had previously been championing. Because strategic culture can infuse the elite community and its institutions with powerful images that override strategic logic, elites may not even accept that they must reverse course despite incoming information pointing to the need to do so. Furthermore, because elite beliefs adapt faster to new information than strategic culture, the same images that once shaped public opinion and empowered decision makers eventually can come to constrain them. ${ }^{39}$ In my case studies, I will examine the extent to which hard-liners are prevented from changing course because they cannot break away from the strategic culture.

In the third phase, domestic elements, out of necessity, come to believe their own rhetoric that war would not be costly, that war now would be less costly than war later, or that the chances of winning a war now would be greater than the chances of winning a later war. The expected relative costs of action are essential to understanding what, if any, preventive action a state might initiate. Essentially, if preventive action is seen as not costly, it becomes more likely. If the expected costs of a particular action are high, that action is less probable. However, even if conflict now is seen as costly, but less so than conflict later, some sort of preventive action is preferable to doing nothing. Because of these calculations, the state becomes risk acceptant and advocates a strong offensive posture that can lead to militarized preventive action. ${ }^{40}$ This applies to both war and preventive actions short of war. Similarly, if war is perceived as inevitable, and war now is seen as inexpensive for the dominant state, it is likely to initiate preventive war in

\footnotetext{
${ }^{39}$ Ibid., 15, fn. 68, 72, 90-98.

${ }^{40}$ Bruce Bueno de Mesquita "maintains that any given configuration of power (balance or preponderance) can produce either war or peace depending on whether leaders are risk-acceptant or risk-averse." Cited in Vasquez, The War Puzzle. Because of this, the distribution of power itself is of less importance for my analysis, beyond the fact that the distribution is shifting.
} 
order to forestall any future threat from the rising challenger. If a limited military action will reduce the future threat, such action might also be considered. A peripheral war will be an option if domestic elements in the dominant power see such a sign of resolve as deterring the challenger. General war against the challenger, on the other hand, may be seen as costly. Therefore, this form of preventive action may be the last option, other than doing nothing, which the dominant state will wish to take.

The perceived chances of favorable outcomes are also essential to understanding what, if any, preventive action a state might initiate. Vasquez suggests, "All other factors being equal, the side that thinks it will win will tend to be the initiator. It makes sense that, once a war is likely, the side with the greater capability and commitment from allies will try to initiate the war, and the side with less capability and weaker commitment from allies will try to delay the start of war." ${ }^{\prime 1}$ This would suggest that the dominant state should consider militarized preventive action as soon as it perceives a rising challenger and determines that war is likely.

If military victory is likely, but less so in the future, some sort of militarized preventive action would be logical. The ultimate form this takes depends on some of the other factors discussed in this project. If military victory is uncertain at the present time, actions short of war may be a more desirable option.

In essence, what is of importance for this project is to attempt to understand the extent to which hard-liners are able to influence foreign policy, determine to what extent domestic elements see threats as inevitable and/or military in nature, and to examine to what extent they are constrained by the strategic culture. Strategic culture becomes important if previously militant or radical hard-liners see evidence of a change, and try to move away from previous

\footnotetext{
${ }^{41}$ Ibid., 220.
} 
hard-line positions, but are unable to do so because they are constrained by the strategic culture that they, in part, helped create.

Finally, the strength of some of these factors determines the form of the likely preventive action. For example, the lower the costs of military action in the short term, the higher the probability of militarized preventive action in the short term. Similarly, the higher the perceived chances of success, the more likely the initiation of preventive action. The decision-making process as outlined above can be broken down as shown in Appendix A.

\section{Dependent Variable: Form of Preventive Action}

As mentioned earlier, a real deficiency in the preventive literature is the lack of attention scholars have paid to preventive action short of war. By conceiving preventive action as a series of categories, it is possible to develop a model that questions why preventive action takes a particular form in a given case. The form of the preventive action then becomes the dependent variable in the DPMP. Below is a discussion outlining the possible responses by a dominant state to a rising challenger.

The first category, that of acquiescence (doing nothing), is not really a form of preventive action. In this case, the dominant state simply allows the power shift to occur. Nonetheless, it is included here because it is a possible outcome of a power shift, and one that occurs in my case studies. The United Kingdom's response to the rise of the United States - removing the Royal Navy from the Western Hemisphere and turning over security of the hemisphere to the U.S.- - is an example of this kind of behavior. The United State's acquiescence to the rise of Japan in the 1860s and 1870s also is a demonstration of this category. Both of these examples are explored in detail in later chapters. 
The second category, accommodation, is a mixed strategy of carrots and sticks on the part of the dominant state. The dominant state takes actions to stymie the rise of the challenger, but it is not willing to confront the challenger with overly coercive instruments. This category includes economic and diplomatic overtures, but of a relatively benign nature. An example of this type of action might be if a dominant state promoted the signing of treaties that prevent the spread of a particular type of military capability. The 1930 London naval disarmament agreement between the United States, the United Kingdom, and Japan is an example of this. It can also include attempts to appease or negotiate a settlement between the dominant state and the challenger. For example, the Soviet Union negotiated a non-aggression pact with Nazi Germany while Germany was rising but still inferior in terms of power. ${ }^{42}$

The third category is that of sustained coercive/confrontational diplomacy. This can include the threat or actual use of embargoes and blockades to prevent a state from achieving some military capability. It also includes the formation of alliances against a particular challenger. The formation of the North Atlantic Treaty Organization, for example, would fall within this category. It also includes the use of actual military resources to send a signal to the challenger that any continued unfriendly action will result in militarized conflict. When the United States sent three warships to Samoa in 1888 to respond to perceived German aggression there, the United States was sending a signal to Bismarck.

The final category is that of militarized preventive action. This category entails several sub categories such as limited military action where military violence is used, but on a limited basis. The goal here is to prevent the challenger state from achieving a specific military

\footnotetext{
${ }^{42}$ However, by the time the aggression pact was signed in 1939, Germany had moved into at least an equal position with the Soviet Union.
} 
capability. ${ }^{43}$ A second sub category of preventive war is peripheral war. This type of war is similar to preventive diplomacy in that it is a signal, but in this case, it can be a signal to allies as well as the challenger. In this case, many military resources are utilized, but the target is not the challenger itself. Instead, a proxy target or third party country is used to demonstrate resolve. One goal, as seen by the dominant state, is to ensure that resources on the periphery are not accessible to the challenger. A second and perhaps even more important motive is that the demonstration of resolve will deter opponents and shore up allies. These peripheral areas often become significant not so much because of their actual military or economic importance, but because their "loss" to the challenger would represent a loss of prestige for the declining state that could open the possibility of defection of allies. Kupchan suggests, "Elites believe in the need to demonstrate resolve because they reason that they can offset insufficiency of material resources by bolstering reputation and prestige. Elites seek to rely on these intangible components of power to compensate for the relative loss of the material components of power."44 As a result, peripheral areas, and the wars fought over them, tend to become more important than their material worth would suggest. The U.S.'s involvement in Korea and Vietnam during the Cold War are examples of this classification of preventive action. ${ }^{45}$

The final sub category is that of general war. General wars are much less limited in scope than the other forms of war and are targeted directly at the challenger. General war is likely to be much more costly than other types of preventive action. ${ }^{46}$ It involves the targeting of multiple sites where research and development, production, and storage of a particular capability are

\footnotetext{
${ }^{43}$ While I believe this to be a valid subcategory, my cases did not turn up any limited military actions. This may be something that is used primarily against rising challengers that are not considered great powers or potential great powers. I believe more research needs to be done regarding this type of case.

${ }^{44}$ Kupchan, The Vulnerability of Empire, 74.

${ }^{45}$ These two cases also fall under the heading of "containment" which is discussed in chapter six.

${ }^{46}$ Vasquez, The War Puzzle, 221.
} 
being conducted. It may involve a land invasion or substantial air and sea bombardment. General war often has as its goal broader implications than other types of war, possibly including the eradication and replacement of the rival government. ${ }^{47}$

With the initial proposed typology in mind, the case studies are scored on a scale from acquiescence to general war, using the criteria outlined above. I then examine each case, using the method of process tracing, to determine to what extent each causal mechanism exists, or what form each causal mechanism takes. The validity of my hypotheses and model are then based on the assessment of the cases. ${ }^{48}$

\section{Testing the DPMP}

In order to test my model, I have generated eleven hypotheses and eleven corresponding standardized questions to ask of each case. ${ }^{49}$ The last two hypotheses and the last two questions help compare the DPMP's predictions against those of two other models. The first of these models tests the predictions of offensive realism, a systemic structural model. The second model tests the predictions of a democratic peace model focused on the domestic structure of both states in a dyad. I suggest that the DPMP outperforms both of these models.

\footnotetext{
${ }^{47}$ My research did not reveal any outbreaks of preventive general war. This suggests that these instances may be exceedingly rare, at least among great powers or potential great powers. Declining great powers seem quite cautious in their interactions with other great powers. Again, more research is needed in this area.

${ }^{48}$ Clearly, my model of preventive action falls between traditional liberal/pluralist and statist/realist concepts. The model takes into account interest groups, but it also treats elite decision makers, as one of the voices - sometimes as the strongest voice - that shapes preventive action decisions. As Stephen Krasner notes, however, there is less likely to be wide dissention among interest groups when it comes to issues such as national security than there might be for economic issues. For this reason, it is not necessary to delve too deeply into the liberal vs. statist debate at this point. For an in-depth discussion regarding the differences between liberal and statist approaches see Stephen D. Krasner, Defending the National Interest: Raw Materials Investment and U.S. Foreign Policy (Princeton, New Jersey: Princeton University Press, 1978).

${ }^{49}$ See section on the method of structured, focused comparison for a discussion of why standardized questions are necessary.
} 


\section{$\underline{\text { Hypotheses }}$}

In order to answer my research questions and test the DPMP, eleven hypotheses have been generated. These are as follows:

$\mathrm{H}_{1}$. The greater the constraints on internal power, the less likely the initiation of militarized preventive action.

$\mathrm{H}_{2}$. The stronger the domestic political constraints, the lower the likelihood of militarized preventive action.

$\mathrm{H}_{3}$. The more militant or radical the ruler belief system, the higher the probability of militarized preventive action. States in which hard-liners emerge and gain dominance over the decision making process are more likely to engage in preventive action.

The following six hypotheses evaluate different aspects of ruler belief systems, primarily in terms of perception.

$\mathrm{H}_{4}$. Threats that are perceived as militarized in nature are more likely to result in militarized preventive action than are threats that are perceived to be non-military in nature.

$\mathrm{H}_{5}$. The greater the perception that conflict is likely or inevitable, the greater the likelihood of preventive action.

$\mathrm{H}_{6}$. States that believe that conflict will not be costly are most likely to initiate preventive action.

$\mathrm{H}_{7}$. States that believe that militarized conflict now, while costly, will be less costly than militarized conflict later, are still motivated to initiate preventive action, though they may be more likely to choose non-militarized preventive action.

$\mathrm{H}_{8}$. States that believe that the chances of winning a war now are greater than winning a war later are more likely to initiate preventive war than states that do not hold this belief.

$\mathrm{H}_{9}$. The greater the perception of a deteriorating status quo, the greater the probability of preventive action. 
These last two hypotheses address the two models against which the DPMP is being

tested.

$\mathrm{H}_{10}$. Offensive realism predicts that unbalanced multipolar systems are more likely to generate instances of militarized preventive action than are any other type of system. ${ }^{50}$

$\mathrm{H}_{11}$. According to Schweller, democracies are unlikely to initiate militarized preventive action, but may choose accommodation or may form a defensive alliance against rising challengers. Non-democracies are likely to engage in militarized preventive action against rising challengers. $^{51}$

From these hypotheses, the following standardized questions have been generated and will be applied to the cases:

1) To what extent is the internal power of the state constrained?

2) To what extent are pro-preventive action elements constrained?

3) What is the nature of the ruler belief system?

4) What is the nature of the threat (military, non-military)?

5) To what extent is conflict seen as likely or inevitable?

6) To what extent do domestic elements believe that a war would not be costly?

7) To what extent is there the belief that a war now would be less costly than a war later?

8) To what extent is there the belief that the chances of winning a war now would be greater than the chances of winning a later war?

9) To what extent do domestic elements think the status quo will get worse for their state if the rising challenger is allowed to continue its ascendancy?

10) What is the nature (polarity) of the international system? I will use this question to determine what the offensive realist model predicts about the states' behavior.

11) What type of government exists in each state, i.e., are either or both democracies? I will use this question to determine what Schweller's model predicts about the states' behavior.

\footnotetext{
${ }^{50}$ John J. Mearsheimer, The Tragedy of Great Power Politics (New York: W. W. Norton \& Company, 2001), 5.

${ }^{51}$ Randall L. Schweller, "Domestic Structure and Preventive War: Are Democracies More Pacific?," World Politics 44 , no. 2 (1992).
} 
These eleven hypotheses and standardized questions allow me to test my cases in order to answer the basic research questions of this project. I am not suggesting that my hypotheses and questions are the only conceivably valid ones. I readily concede that many more hypotheses and questions are possible and perhaps desirable. I do hope, however, that the reader will approach this work with an open mind, recognizing that this is a first cut at forming a new understanding of the initiation of preventive action. If evidence supporting these hypotheses is found in the cases, it will suggest that the theory is credible. Furthermore, such findings would validate my conceptualization of preventive action as taking different forms. The research regarding the case studies will constitute the bulk of this project.

It is also necessary to address whether alternative models make the same or different predictions on processes and outcomes in a given case. In general, the strongest possible supporting evidence for a model is a case that is least likely for that model but most likely for all alternative models, and one where at the same time the alternative models collectively predict an outcome very different from that of the least likely model. In such a case, if the least likely model turns out to be accurate, it deserves full credit for a prediction that cannot also be ascribed to other models (though it could still be spurious and due to an as-yet undiscovered theory). This might be called a toughest test case. ${ }^{52}$

The strongest possible evidence weakening a model is when a case is most likely for that model and for alternative models, and all these models make the same prediction. In such a case, if the prediction proves wrong, the failure of the model cannot be attributed to the countervailing influence of variables from other models (again, left-out variables can still weaken the strength of this inference). This might be called an easiest test case. If a model and all the alternatives fail in such a case, it should be considered a deviant case and might prove fruitful for looking for an

\footnotetext{
${ }^{52}$ George and Bennett, Case Studies and Theory Development in the Social Sciences, Ch. 4.
} 
undiscovered causal path or variable that might be worthy of theoretical elaboration. Cases usually fall somewhere between being most and least likely for particular models. ${ }^{53}$

I will test my Domestic Politics Model of Prevention against two other models derived from the literature. The first of these models is suggested by offensive realism. ${ }^{54}$ A real weakness of this model is that it only predicts preventive action in binomial terms: either war or no war. To supplement this model, I also utilize a second model derived from the democratic peace literature, particularly Schweller's article "Domestic Structure and Preventive War: Are Democracies More Pacific?" In this seminal article, Schweller suggests a typology of when states are likely to engage in preventive war, and when they are likely to take actions short of war. ${ }^{55}$ I suggest that my model does a superior job at predicting when states are likely to engage in preventive action, and what form that action is likely to take.

\section{Alternative Model 1: Offensive Realism as a Structural Model of Preventive War}

In order to test the DPMP, I compare its predictive power to that of two other models. The first of these models examines the structure of the international system. The balance of power within the international system — whether it is bipolar, balanced multipolar, or unbalanced multipolar-has long been considered the primary factor in determining whether preventive war will occur. I test whether it is able to predict whether preventive action occurs, and if it is able to predict what form any preventive action takes. If it is able to do so, the importance of the DPMP will be weakened. On the other hand, if this model proves inadequate in its predictions, and the DPMP proves more accurate, my ideas are given more importance.

\footnotetext{
${ }^{53}$ Ibid., Ch. 1, 4, 5, 7 .

${ }^{54}$ For this model I rely on Mearsheimer's The Tragedy of Great Power Politics. See Mearsheimer, The Tragedy of Great Power Politics.

${ }^{55}$ Schweller, "Domestic Structure and Preventive War: Are Democracies More Pacific?."
} 
John Mearsheimer, with his theory of offensive realism, presents a refined picture of the international system. He suggests that major variations of balance in the international system can affect a nation's calculations regarding the efficacy of war. Mearsheimer proposes a variety of systemic possibilities ranging from balanced bipolar systems to unbalanced multipolar systems. ${ }^{56}$ He suggest that war is most likely to occur in a system in which a potential hegemon is emerging, what he calls an unbalanced multipolarity. On the other hand, war is least likely in a bipolar system in which two powers have roughly equal amounts of power. In between these two extremes is what he calls balanced multipolarity in which several states have roughly equal power, and there is no superior state. He suggests that in such a case, war is more likely than in a bipolar system, but less likely than in an unbalanced multipolar system. ${ }^{57}$

I use Mearsheimer's conceptualization of the polarity of the system in order to test my model. If preventive wars are initiated at a higher rate during periods of unbalanced multipolarity, less so during balanced multipolarity, and still less during bipolarity, the offensive realism model will be strengthened. Mearsheimer lists the polarity of the system as follows:

1) Napoleonic era I, 1792-93 (1 year), balanced multipolarity

2) Napoleonic era II, 1793-1815 (22 years), unbalanced multipolarity

3) Nineteenth century, 1815-1902 (88 years), balanced multipolarity

4) Kaiserreich era, 1903-18 (16 years), unbalanced multipolarity

5) Interwar years, 1919-38 (20 years), balanced multipolarity

6) Nazi era, 1939-45 (6 years), unbalanced multipolarity

7) Cold War, 1945-1990 (46 years), bipolarity ${ }^{58}$

\footnotetext{
${ }^{56}$ Kenneth Waltz points out that stability and peace do not necessarily go hand-in-hand. See Kenneth N. Waltz, "The Emerging Structure of International Politics," International Security 18, no. 2 (1993).

${ }_{58}^{57}$ Mearsheimer, The Tragedy of Great Power Politics, 42-46.

${ }^{58}$ Ibid. (New York and London), 348. Dale Copeland also suggests that the polarity of the system and the relationship of the declining state's military power in comparison to its economic and potential power largely determine the extent to which decline leads to war. See Copeland, The Origins of Major War, 21.
} 
I suggest that a model based on domestic factors will yield better predictions than one based on systemic mechanisms alone. One serious drawback of the offensive realism model is that it is not concerned with preventive action short of war.

\section{Alternative Model 2: Schweller's Democratic Peace as a Model of Preventive War/Action}

The second alternative model I use to test the DPMP is based on Schweller's predictions about the domestic structure of states and proclivity to initiate preventive war. Schweller argues that it is the internal domestic structure - whether democratic or not—that determines how a declining dominant power responds to a rising challenger. He concludes that when faced with a democratic rising challenger, democracies do not initiate preventive war, but instead accommodate the challenger. When it comes to non-democratic challengers, however, democratic states attempt to form defensive alliance systems. Also of interest, though, is that he leaves open the possibility that a democracy may initiate preventive war against a nondemocratic challenger if the dominant democratic state believes that such a war would not be long or costly. Meanwhile, non-democratic states, when faced with a challenger (whether democratic or not), will either form a defensive alliance or will initiate preventive war. Accommodation is not in their nature. In all, Schweller suggests that there are four possible responses by a dominant state facing a challenger: 1) accommodation, 2) internal balancingwhich is difficult for democracies because of the costs involved in building up military power, 3 ) alliance formation, and 4) preventive war. ${ }^{59}$ In sum, Schweller's model is important both because he examines the internal structure of states, and because he suggests a range of responses by the dominant state. If Schweller's model accurately predicts the behavior of states in my cases, the

\footnotetext{
${ }^{59}$ Schweller, "Domestic Structure and Preventive War: Are Democracies More Pacific?."
} 
importance of my model will be weakened. I predict, however, that my DPMP will outperform both Schweller's model and the offensive realism model.

\section{Methodology}

Alexander George and Andrew Bennett have devised a set of interrelated methods that are useful in dissecting the causal mechanisms of preventive action. ${ }^{60}$ The method of structured, focused comparison utilizes case studies, process tracing, and typological theory. These tools are examined in this section and explanation is given as to how they will be utilized in this project. I examine several cases of power shifts, both shifts that resulted in preventive action of different stripes, as well as cases that did not result in preventive action at all. These case studies are examined using the process tracing method within a structured-focused comparison framework, with a final goal of developing a typological theory of prevention that explains why preventive action sometimes occurs and other times does not, as well as explaining why preventive action takes the form it does in any given case.

\section{The Method of Structured, Focused Comparison}

George and Bennett suggest that comparative case studies can use within-case analysis of individual cases as well as case comparisons to assess and refine existing theories, and more generally, to develop empirical theory. The method of doing so is "structured" in that the same standardized, general questions are asked of each case in order to guide data collection, thereby making possible systematic comparison and accumulation of the findings of the cases. The method is "focused" in that it deals with only certain aspects of the cases; that is, a selective

\footnotetext{
${ }^{60}$ George and Bennett, Case Studies and Theory Development in the Social Sciences.
} 
theoretical focus guides the analysis of the cases. Not all the theoretically interesting aspects of a case can be usefully addressed in a single study. ${ }^{61}$ In response to these methodological demands, I have developed a standardized set of questions that focus on the theoretically important aspects of my cases.

\section{The Case Study Method}

George and Bennett suggest that the case study method is particularly useful in specifying and measuring complex qualitative variables. Complex causal relations involve interacting causal variables that are not independent of each other. This method provides useful tools with which researchers can inductively identify new variables, hypotheses, and complex interaction effects. The case study method allows the researcher to develop contingent generalizations or typological theories. When done correctly, case studies allow the researcher to identify and test "causal mechanisms"- the social or political processes through which variables exert causal effects. ${ }^{62}$ I use this method because the causes of preventive action are complex, as will be demonstrated in this study.

In examining preventive action, a power shift is a necessary but not sufficient condition. ${ }^{63}$ Without a power shift, an action cannot be described as preventive. As Levy suggests, a power shift is an independent variable, but not all power shifts lead to war. I argue that not all power shifts even lead to preventive action. Some power shifts are met with inaction. For example, Russia and then the Soviet Union often chose to take no action against rising powers. The United States also allowed the United Kingdom and Japan to rise in relative power after World War II.

\footnotetext{
${ }^{61}$ Ibid., 67-72.

${ }^{62}$ Ibid., Ch. 1.

${ }^{63}$ In order to assess power shifts after 1816, I use the Composite Index of National Capability (CINC) score derived from the National Material Capabilities (v3.02) index. This is part of the Correlates of War (COW) project and can be accessed at http://www.correlatesofwar.org/.
} 
These are only two examples of several presented in this research where the dominant declining power took no action against a rising challenger.

There are causal mechanisms that determine whether, in the presence of a power shift, preventive action will be initiated, and what form that preventive action will take. These causal mechanisms, and the resulting outcomes, are the subject of this study. Because of the complexity of these causal mechanisms, this study is necessarily concerned with the probability of a given form of preventive action. My model, therefore, is not deterministic in that if conditions A and B are present, outcome $\mathrm{C}$ will occur. Instead, I am suggesting that if A and B exist, there is a probability that $\mathrm{C}$ will occur, and that probability is higher than outcome $\mathrm{D}$.

George and Bennett note that case study methods can address the issue of equifinalitywhere the same outcome can arise through different causal paths in which there may be no single non-trivial necessary or sufficient condition. In other words, different mixes of causal variables can have the same effect. Case studies can also address the issue of multifinality-where contingent generalizations explicitly outline the differing background conditions under which the same value of a causal mechanism can have different effects. ${ }^{64}$ Both conditions occur in my case studies. For example equifinality is demonstrated by the fact that both the United Kingdom and Russia engaged in non-militarized preventive action when faced by militarized threats. The UK engaged in a naval buildup and then a redeployment of naval forces to contain the Russian threat at the turn of the twentieth century. The Russians, on the other hand, chose to develop closer ties with France in the 1890s to balance against a rising Germany. Both of these are examples of nonmilitarized preventive action, but they come about along different causal pathways. To demonstrate multifinality, we can examine the American reaction to the militarized threats posed by the Soviet Union in the 1920s and 1930s versus its reaction to the militarized threats from the

\footnotetext{
${ }^{64}$ George and Bennett, Case Studies and Theory Development in the Social Sciences, 9-10.
} 
Soviet Union after the Second World War. In looking at the causal paths in the models in Appendix A, we can see that the causal paths are the same until we get to the question of status quo. At this point, the models diverge. Nonetheless, for the variables "nature of threat" and "likelihood of conflict" the values are the same but ultimately different policy prescriptions are reached. ${ }^{65}$

When choosing any method for research, the researcher must answer the question of why one method is chosen over another. One advantage of the case study method is that the likelihood that relevant variables will be left out is lower than for statistical methods. This is particularly important in the early stages of theory development, which I believe preventive action studies are in. Case study methods allow for the inductive identification of variables as well as their deductive specification. Indeed, one of the most visible and important contributions of case study methods has been to identify causal variables that have been left out or insufficiently examined by studies relying on purely deductive theories or statistical methods. This dissertation contributes to our understanding of the variables that play a part in the initiation of different forms of preventive action. ${ }^{66}$ I approach this research project from the standpoint that prior theories of preventive war/action have focused almost exclusively on systemic or structural variables, and have not taken an inductive approach. In this dissertation, I identify alternative causal mechanisms that will explain preventive action in a more comprehensive way.

Having settled on the case study method, then, the next task is to select the case or cases which the researcher will examine. George and Bennett suggest that case selection is an opportunistic as well as a structured process. Researchers should look for whether the addition of

\footnotetext{
${ }^{65}$ This leads one to think that, at least as far as our cases are concerned, the issue of multifinality might be a case of misidentification. What we see as different outcomes from the same causal path might simply be an instance of missing intervening variables.

${ }^{66}$ George and Bennett, Case Studies and Theory Development in the Social Sciences, Ch. 1.
} 
one or a few cases to a study might provide useful comparisons or allow inferences on additional types of cases. The primary criterion for case selection should be relevance to the research objective of the study, whether it includes theory testing and/or heuristic purposes. The research objective must be integrated into decisions on whether the research strategy should include one or a few case studies, case comparisons and/or within-case analysis, and so on. The cases must be selected to provide the kind of control and variation required by the research problem. ${ }^{67}$

The case study method is sensitive to the manner in which cases are selected. A single crucial or nearly crucial case can strongly support or undermine a theory. A crucial case is one that must closely fit a theory if one is to have confidence in the theory's validity, or conversely, must not fit equally well with any rule contrary to that proposed. In a crucial case it must be extremely difficult to dismiss any finding contrary to the theory as simply "deviant" - due to chance, or the operation of unconsidered factors. Studies of deviant cases are particularly useful for identifying new variables or causal mechanisms. By definition, deviant cases have outcomes that existing theories do not anticipate. George and Bennett note that truly crucial cases rarely occur in nature or the social world and suggest the alternative of studying "most likely" and "least likely" cases. ${ }^{68}$

In a most likely case, the independent variable(s) posited by a theory are at values that strongly posit an outcome or posit an extreme outcome. In a least likely case, the independent variables in a theory are at values that only weakly predict an outcome or predict a low magnitude outcome. Most likely cases are tailored to cast strong doubt on theories if the theories do not fit, while least likely cases can help strengthen support for theories that fit even cases where they should be weak. One useful means determining whether a case is most likely or least

\footnotetext{
${ }^{67}$ Ibid.

${ }^{68}$ Ibid., Ch.1 and Ch. 4.
} 
likely is for case study researchers to include a typological table that shows the values of variables in the case(s) studied across competing hypotheses. It is important to consider not only whether a case is most or least likely for a given theory, but whether it is at the same time most or least likely for alternative theories, and a typological table helps identify which variables in a case may favor alternative theories. ${ }^{69}$ For this project, I suggest that the British response to a rising United States and the U.S. response to a rising Soviet Union after World War II are critical or most likely cases. These will be outlined further in the case studies of the dissertation.

As noted throughout this dissertation, preventive action can refer to a full spectrum of responses to a rising challenger. In order to demonstrate the full range of preventive action, I have surveyed the historical record and chosen several cases that fit within my framework. Necessarily, I am unable to defend the cases presented here as a scientific sample. Instead, the cases I have chosen represent the range of preventive action in the Domestic Politics Model of Prevention. The three cases I have chosen, I would argue, also represent three of the most important episodes of the past two hundred years. The decline of great powers and super powers has shaped global politics during this period. I purposefully limited my cases to the modern era, and I limited the cases to the great powers. ${ }^{70}$ This necessarily means European states, with the addition of the United States and Japan in the nineteenth and twentieth centuries.

One of the first questions that must be addressed about the case studies is "Why these particular cases?" One answer to that question lies in my desire for precision. I wanted to use objective data by which I could gage the rise and fall of states. ${ }^{71}$ I did not want to rely on the

\footnotetext{
${ }^{69}$ Ibid., Ch. 1 and Ch. 4.

${ }^{70}$ This is not to suggest that the theory I am laying out applies only to great powers. I would argue that these same dynamics will exist whenever the situation exists of a dominant declining state and a rising challenger, and should be an important area of further research.

${ }^{71}$ I use the Correlates of War project figures to determine relative decline of states. This data allows me to chart the rise and fall of states beginning in 1816. This data is available from http://www.correlatesofwar.org/.
} 
observations of historians to make this determination. A second reason I decided to limit my cases to the "modern" great powers is because I believe, as Stephen Van Evera suggests, more is to be learned about the current state of affairs in the international system from the more recent past than from the ancient world. The study of modern times may provide a better understanding of how to prevent future clashes since the causes of modern conflict are more prone to recur. ${ }^{72}$

The desire for objectivity and precision, and the belief that more applicable knowledge was to be gained from modern examples made me immediately rule out studying ancient civilizations such as ancient China, ancient India, the Ottoman Empire, the ancient Greeks, the Roman Empire, the Aztecs, or the Mayans. While rough estimates of power could be derived from historical accounts, my aim was to be as precise as possible when measuring the relative rise and decline of states. For similar reasons I chose not to use other eras that might have made logical sense.

For example, 1648 may have been a natural choice with the ending of the Thirty Years' War and the signing of the Treaty of Westphalia. The date 1519 might also seem an apt starting point. With the crowning of Charles V as Holy Roman Emperor over all Habsburg lands; one could argue this date would be a valid point of origin. Similarly, one could argue that the signing of the Treaty of the Pyrenees in 1659 might be a logical starting point. With the signing of the treaty, Spain retreated into the second tier of states, ending a push for hegemony by the combined Habsburg forces of Spain and Austria. Nonetheless, I chose to examine states since 1816 , because of the availability of objective measures of state power and the belief that more recent examples of preventive action would provide better predictors of future preventive action.

\footnotetext{
${ }^{72}$ Stephen Van Evera, Causes of War: Power and the Roots of Conflict (Ithaca and London: Cornell University Press, 1999), 13.
} 
Since I am interested in great power preventive action, by definition any action in my case studies must include at least one of the great powers. ${ }^{73}$ Based on a survey of historical cases that fit my criteria, I have chosen three cases that I believe are both representative of preventive action in the modern era and are interesting examples. These constitute chapters 4 through 6 of the research project. Chapter 4 traces the decline of the United Kingdom and its response to challenges from Russia, the United States, Germany, and Japan. Chapter 5 examines the decline of Russia and the Soviet Union and its responses to rising challengers. Chapter 6 studies the decline of the United States vis-à-vis Russia, Germany, Japan, and the United Kingdom from 1849 to 1996.

I acknowledge that the historical periods under examination are complex, and that interpretations other than those offered in this study are possible. I do ask the reader, however, to suspend his or her preconceptions and to remain open to the evidence and interpretations presented here. Furthermore, this project is primarily concerned with how states come to the decision to initiate a particular level of preventive action. Therefore, the case studies presented here focus mainly on decision-making conducted during peacetime, not on wartime planning.

The reader will doubtlessly notice that I spend very little time discussing the causes of rising states and declining power. These elements have been covered in detail in other studiesparticularly the literature on power transition theory. The purpose of this study is not to explore the underlying causes of decline or ascendance, but instead it is to understand what decision

\footnotetext{
${ }^{73}$ A word should be said about the limitations of this study. Because I am limiting my study to the modern era, and I am only interested in examining the actions taken by dominant states, and in this case major powers, I cannot and do not wish to make a claim that my findings are applicable to an infinite population. However, I would argue that if evidence is found that supports my basic hypotheses, it should prompt further study that includes non-major powers, and perhaps situations in which inferior states initiate preventive action. Furthermore, I am more interested in discovering the conditions under which the hypothesized outcomes occur, and the "mechanisms through which they occur, rather than uncovering the frequency with which those conditions and their outcomes arise." See George and Bennett, Case Studies and Theory Development in the Social Sciences.
} 
makers do with the knowledge that their state is in decline and that challengers are rising. I want to understand why decision makers in declining states react the way they do to rising challengers.

A second issue facing researchers in the case study method, in addition to that of case selection, is the problem of reconciling conflicting interpretations of the same cases. As mentioned earlier, I have avoided one problem - that of interpreting state decline and ascendance — by using objective data obtained from the Correlates of War Project. Additionally, one remedy to this quandary includes identifying and addressing factual errors, disagreements, and misunderstandings. ${ }^{74}$ In order to overcome these issues, I rely on standard scholarly historical works, and where disagreements do emerge, I will acknowledge and attempt to reconcile them.

I approach my cases in two ways. On the one hand, I compare cases with similar outcomes, i.e., cases that end in war, in order to identify the causal mechanisms associated with such outcomes. On the other hand, I compare dissimilar cases, i.e., cases that end in war and cases that end in action short of militarized conflict, in order to identify the conditions and causal mechanisms that served to account for this difference in outcome. Through these comparisons I hope to isolate the causal mechanisms that lead policy makers to choose specific preventive action policies.

\section{Process Tracing}

As mentioned earlier, the presence of the preventive motivation is essential in being able to label any action as "preventive." In order to systematically examine my cases and search for evidence of preventive motivation, I utilize the method of process tracing. This technique is valuable because it "link[s] theory and empirical work by using the observable implications of a

\footnotetext{
${ }^{74}$ Ibid., 74-79.
} 
theory to suggest new observations that should be made to evaluate the theory." ${ }^{, 75}$ The use of process tracing can strengthen the inferences that would otherwise have to be made on the basis of comparative methods alone. It can permit causal inference on the basis of a few cases or even a single case ${ }^{76}$

Process tracing, according to George and Bennett, is the method of looking at the observable variables along a hypothesized causal process through which a causal mechanism exerts an observed causal effect. It is an attempt to trace empirically the temporal and possibly causal sequence of events within a case that intervene between independent variables and observed outcomes. ${ }^{77}$ Stephen Van Evera explains the method of process tracing as follows: "The investigator explores the chain of events or the decision-making process by which initial case conditions are translated into case outcomes. The cause-effect link that connects independent variable and outcome is unwrapped and divided into smaller steps; then the investigator looks for observable evidence of each step." Furthermore, "Evidence that a given stimulus caused a given response can be sought in the sequence and structure of events and/or in the testimony of actors explaining why they acted as they did." ${ }^{\text {78 }}$ It is for this reason that I will examine the primary actors within the dominant state in each case.

Process tracing may help identify which interactions and potentially causal mechanisms in imperfectly matched cases can be ruled out as having causal significance. In other words, process tracing can test whether seemingly causal mechanisms are spurious and to uncover supposedly unrelated variables that may in fact be causal. George and Bennett have laid out the

\footnotetext{
${ }^{75}$ Gary King, Robert O. Keohane, and Sidney Verba, Designing Social Inquiry: Scientific Inference in Qualitative Research (Princeton, New Jersey: Princeton University Press, 1994), 226-28. See also Alexander L. George and Timothy J. McKeown, "Case Studies and Theories of Organizational Decision Making," in Advances in Information Processing in Organizations (Greenwich, Conn.: JAI Press, 1985).

${ }^{76}$ George and Bennett, Case Studies and Theory Development in the Social Sciences, Ch. 10.

${ }^{77}$ Ibid.

${ }^{78}$ Stephen Van Evera, Methods for Students of Political Science (Ithaca, NY: Cornell University Press, 1997), $64-$ 65.
} 
criteria by which hypotheses can be tested. If all but one of the causal mechanisms that differ between the two cases can be ruled out via process tracing, a stronger (though still not definitive) basis exists for attributing causal significance to the remaining causal mechanism. If process tracing shows that a single step in the hypothesized causal chain in a case is not as predicted, then an unmodified version of the hypothesis cannot explain that case, even if it does explain most or even all other cases. Similarly, if there is only one intervening step in the hypothesized process, and this is observed to be untrue in the case, the hypothesis cannot explain that case. If a complex causal hypothesis involves several steps and even one of these is observed to be inoperative, the hypothesis cannot explain the case. If the hypothesized result does not materialize, even though a given causal mechanism was present, this would suggest that either the causal mechanism is not sufficient or there is a spurious relationship. ${ }^{79}$ These criteria will be used in my cases.

Process tracing tests whether a proposed explanation, or causal mechanism, is consistent with the evidence in a given case, and by extension whether the same causal process might apply to a category of cases with similar causal mechanisms. It can help identify a specific causal process that may explain an instance of a particular phenomenon. Process tracing can be especially useful in determining whether the phenomenon being investigated is characterized by equifinality. Process tracing can identify paths to an outcome, and can point out causal mechanisms that were left out in the initial comparison of cases. ${ }^{80}$ Furthermore, Van Evera suggests, "Process predictions are often unique— no other theories predict the same pattern of

\footnotetext{
${ }^{79}$ George and Bennett, Case Studies and Theory Development in the Social Sciences, Ch. 10. ${ }^{80}$ Ibid.
} 
events or the same actor testimony on their motives - hence process tracing often offers strong tests of a theory."

In sum, process tracing will assist me in determining to what extent each of my predicted causal mechanisms is effecting the foreign policy decisions of domestic elements. In addition, it will help me discard any causal mechanisms that might be spurious in relation to the type of preventive action policies that are eventually chosen. Process tracing will also allow me to discover potentially important causal mechanisms that I have omitted from my initial model.

\section{Typological Theories}

Case studies, through the use of process tracing, can be used inductively to develop and refine typological theories through a "building block" approach that maps out the alternative causal paths to the outcome of interest. A typological theory is a typology that is specified in terms of an underlying theory or set of theories that address not only how these causal mechanisms act singly but how they behave in specified conjunctive combinations. Each case potentially provides a new component in the construction of a comprehensive typological theory. Differentiated explanations of the outcomes of the cases that are all instances of the class of events being investigated become a part of a cumulative typological theory, or a "repertoire of causal mechanisms" of that phenomenon. ${ }^{82}$

The aim is to proceed incrementally toward the goal of developing a typological theory. George and Bennett suggest that by opting for this more flexible strategy, the investigator may gradually build a typology and a typological theory via empirical analysis of cases within a theoretical framework. Concern over the risk of a premature commitment to a well-defined,

\footnotetext{
${ }^{81}$ Van Evera, Methods for Students of Political Science, 64-65.

${ }^{82}$ George and Bennett, Case Studies and Theory Development in the Social Sciences, Ch. 11.
} 
comprehensive typology, one that may prove inadequate after much research on a set of cases selected for that typology, plays a role in encouraging a more gradual approach. For example, an empirical approach relying on historical explanations for different cases of preventive action enables the investigator to discover more general types of preventive action, some of which may encompass several cases, and to identify generic explanations for each type of preventive action. The different causal patterns of preventive action become part of a typological theory. Such a differentiated theory of prevention is significantly different from, and should be more useful than, a theory that attempts to provide a single explanation for all preventive action. It should also prove more valuable than systemic and structural theories that examine only preventive war. Typological theories contribute to the development of a rich, differentiated theory on the phenomenon in question, rather than a very general theory. ${ }^{83}$

Typological theories are useful in showing that different combinations of causal mechanisms may interact to produce similar outcomes on the dependent variable. The most appropriate form for modeling the complexity of equifinality and multifinality is often that of typological theories. The resulting theories usually focus on interactions among combinations of causal mechanisms, rather than causal mechanisms considered alone or isolated through means of statistical control. Typological theorizing, as opposed to the simple use of typologies, pushes theorists to try to anticipate and explain interaction effects, although there is no guarantee that they will do so adequately. Typological theories address the problem of equifinality directly, acknowledging and even taking advantage of the fact that there may be alternative causal paths that lead to the same or similar outcomes. The development and refinement of typological theories, as opposed to typologies, is a key goal of theorizing on social phenomena characterized by complex interactions among numerous causal mechanisms that may be causal even though

${ }^{83}$ Ibid. 
they are not necessary or sufficient conditions. They may explain how the same level of a particular causal mechanism can lead to different outcomes depending on the values of other causal mechanisms, if the goal is to explain the causal powers of a single causal mechanism. ${ }^{84}$

Typological theories identify generalized pathways, whether the path in question has occurred only once, a thousand times, or is merely hypothesized as a potential path that has not yet occurred at all. Specific pathways can be explained by known causal mechanisms. According to George and Bennett, examples of causal mechanisms include: evolutionary selection, socialization, emulation, collective action problems, principle-agent problems, problems of credible commitments, two-level games and learning, and functional forms (such as linearity, path dependency, tipping points, geometric progressions, equifinality, multifinality, and asymptotic limits). ${ }^{85}$

Typological theories contribute to specific case study research designs and the selection of cases in the following ways. If two cases are to be regarded as typologically similar, or are common in the values of all the causal mechanisms and thus occupy the same cell in the typology, then they should have similar outcomes. This offers the most basic test of the validity of the specification of the type. If the outcomes of typologically similar cases differ, then the researcher should check for measurement error and for the presence of probabilistic causal processes. To the extent that these can be ruled out, a new causal mechanism (or several) in which the cases differ may need to be added to the typology and linked to a causal theory that can then be generalized. For example, if two states in my cases show similar values on the causal

\footnotetext{
${ }^{84}$ Ibid.

${ }^{85}$ Ibid.
} 
mechanisms, they should initiate similar preventive actions. If the outcomes are not similar, I may need to examine other factors that might be present. ${ }^{86}$

A second research design involves two cases that occupy adjacent cells in the typology and thus differ only in the outcome and in one causal mechanism. If exogenous causal mechanism can be ruled out as a source of variation in the outcome (admittedly not a simple matter), then differences in the outcome can be attributed to the one causal mechanism in the typology on which the cases differ. This method uses a typological theory to establish a controlled comparison of similar cases. ${ }^{87}$

For each case, I will determine which domestic elements are the most powerful inside the dominant state and their ability to shape foreign policy, particularly if they have preventive action leanings. I will also examine the extent to which hard-liners dominate the decision making process of the dominant state. Furthermore, I will assess the threat or perceived threat as seen by the leadership of the dominant state. I will also examine the domestic elements' perceptions regarding the timing of conflict. From this discussion, I have developed a preliminary typology (see Appendix B) that will guide the elements I examine in my process tracing of the case studies.

In this chapter, I have detailed the components of the Domestic Politics Model of Prevention. I have also explored several different theoretical models, which I will use to test the validity of my own model. In the next four chapters, I explore my cases using the theoretical framework and methods developed in this chapter.

\footnotetext{
${ }^{86}$ Ibid.

${ }^{87}$ Ibid.
} 


\section{Chapter Four The Decline of the United Kingdom}

This chapter examines the decline of the United Kingdom vis-à-vis several rising powers from 1816 to 1914 , with a focus on the period $1895-1905 .{ }^{1}$ The first section of this chapter is meant to serve as a general overview of British decline. The rest of the chapter will delve into particular aspects of Britain's relative decline and the specific threats to its dominance of the international system.

In 1870, only England and Belgium could be described as "highly industrialized." ${ }^{2}$ By 1900, this was no longer the case, with Germany, the United States, Russia, and Japan all embarking on the path of industrialization. In the cases of Germany and the United States, Britain had been surpassed in many measures of industrial power. Even in the area of world trade, in which Britain had long dominated, there was a measure of relative decline. ${ }^{3}$ This is reflected in Britain's Composite Index of National Capability (CINC) score which trended downward after $1816 .^{4}$

\footnotetext{
${ }^{1}$ I focus on this time period for several reasons: 1) it seems to be representative of the larger trend of British decline, 2) there is very good documentation regarding strategic decisions taken by a variety of British leaders during this period, and 3) it became clear during the research process that covering the entire 1816-1962 time frame was simply not practical.

${ }^{2}$ F. H. Hinsely, ed., The Cambridge Modern History: Volume Xi Material Progress and World-Wide Problems 1870-1898, XIV vols., vol. XI, The New Cambridge Modern History (London: Cambridge University Press, 1962), 2. Unfortunately, Hinsely does not define what exactly he means by the term "highly industrialized."

${ }^{3}$ Aaron L. Friedberg, The Weary Titan: Britain and the Experience of Relative Decline, 1895 - 1905 (Princeton, New Jersey: Princeton University Press, 1988), 24. This situation is reflected in the National Material Capabilities index. For this chapter, I rely heavily on Friedberg's analysis of this time period. His book is the most concise and yet detailed account I have found. I supplement it throughout the chapter, but his book clearly forms the backbone of this chapter.

${ }^{4}$ As mentioned in chapter three, in order to assess power shifts after 1816, I use the Composite Index of National Capability (CINC) score derived from the National Material Capabilities (v3.02) index. This is part of the Correlates of War (COW) project and can be accessed at http://www.correlatesofwar.org/.
} 


\section{$\underline{\text { Power Relations }}$}

$\underline{\text { United Kingdom vis-à-vis the United States }}$

From 1816 until 1892, the United Kingdom was dominant over the United States.

Friedberg notes, “In the early 1870s Britain was averaging $£ 230$ million in exports per year, greater than the combined total of the United States and Germany." Despite its dominant position, the UK was declining in terms of relative power vis-à-vis the United States during this period. The only significant exception to this was between 1865 and 1867 when the Unites States was in the wake of its civil war. By 1868, the UK's downward slide was once again apparent. In 1892, the United States' CINC score reached parity with the United Kingdom for the first time. From 1893 to 1896, the United Kingdom regained its position as the dominant power between the two, but just barely. In 1897, the United States reemerged as the dominant state, and has held that position ever since. See Figure 4.1 below.

\section{Figure 4.1}

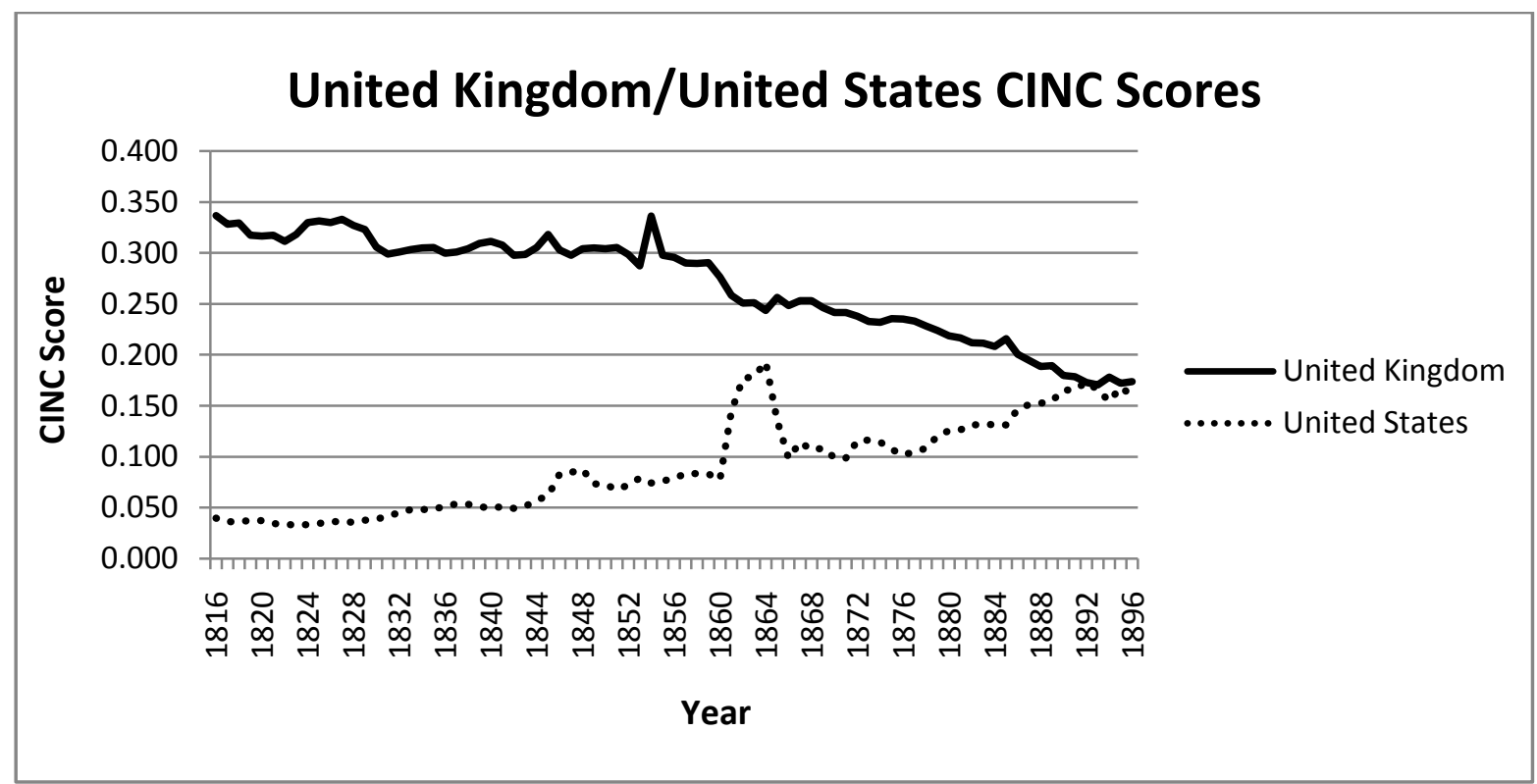

\footnotetext{
${ }^{5}$ Friedberg, The Weary Titan: Britain and the Experience of Relative Decline, 1895 - 1905, 34.
} 


\section{United Kingdom vis-à-vis Prussia/Germany}

Closer to the home island, Germany had emerged as the biggest threat to the Empire by the early 1900s. Germany's CINC score first overtook Britain in 1905, and Germany held the lead from 1905 to 1915 . From 1916 to 1918, the two countries oscillated between dominant and challenger, but it was clear that Germany was becoming a powerhouse on the Continent. Germany's economy overtook that of Britain and Germany's population, which had been 39 million in 1870, had ballooned to 65 million in 1913. During the same period, Britain's population had only increased from 31 million to 46 million. In 1870, Britain's GDP had been 40 percent higher than Germany’s. By 1913, Germany's was 6 percent higher than Britain's. In 1880, Britain's share of world manufacturing production was 23 percent while Germany's was 8 percent. In 1913, the figures were 14 and 15 percent respectively. ${ }^{6}$ In the wake of the First World War, however, Britain retook the lead from Germany until 1934, at which time Germany again gained dominance until the end of World War II. Germany was divided at the end of the war, and it was not until 1990 that a unified Germany reemerged on the international scene. When Germany did resurface, it was dominant over Britain. It has maintained its superiority since that time. See Figure 4.2 below.

\footnotetext{
${ }^{6}$ Niall Ferguson, Empire: The Rise and Demise of the British World Order and the Lessons for Global Power (New York: Basic Books, 2002), 240. See also Austen Albu's introduction to E. E. Williams, Made in Germany (Sussex, England: The Harvester Press, 1973).
} 


\section{Figure 4.2}

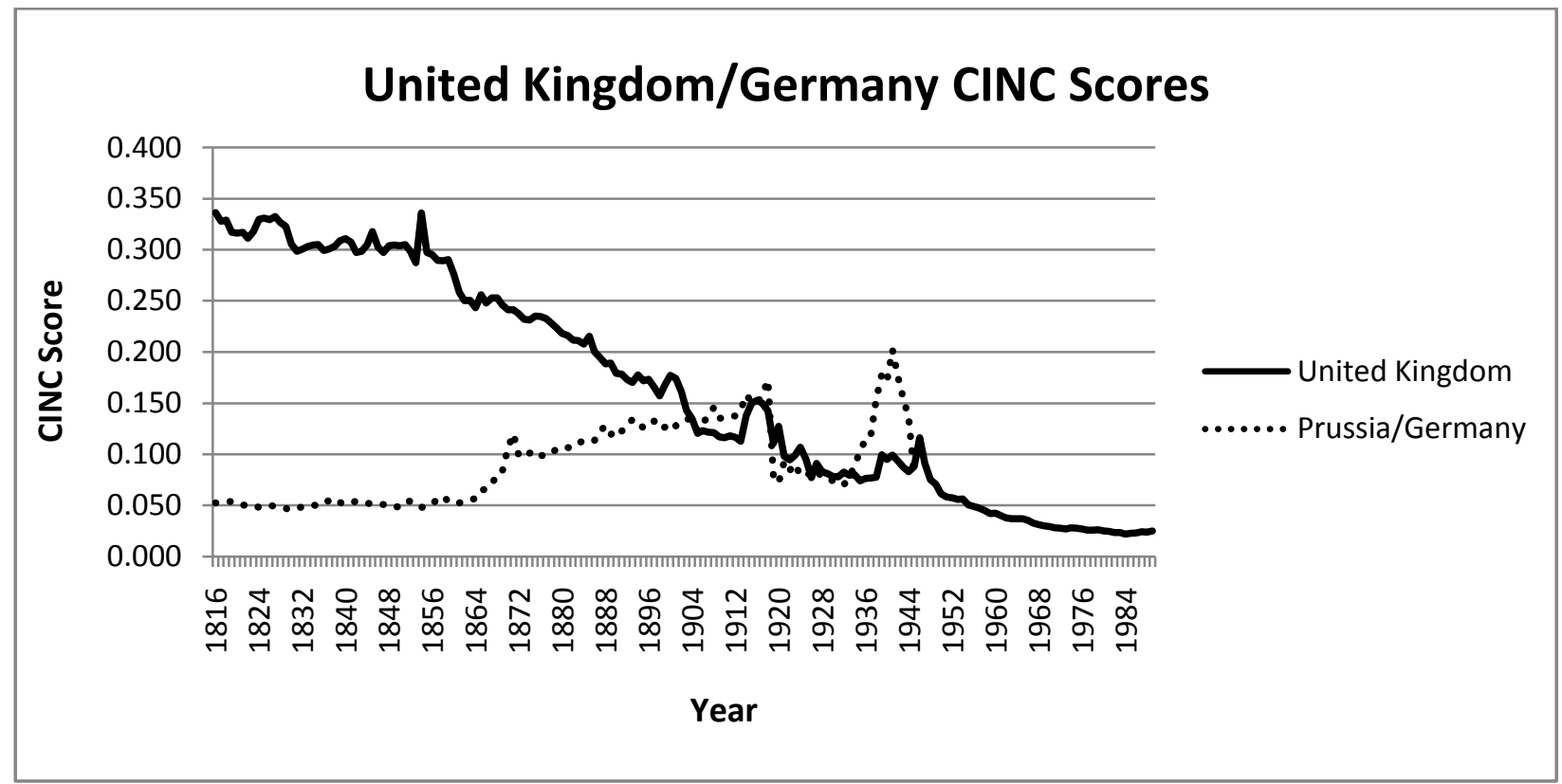

Britain's decline was apparent to the British press, and thus to British decision makers and the British public. Friedberg notes, "In 1896 Ernest Williams, a journalist for the New Review, tapped a deep wellspring of anxiety over this new situation with articles and, later, a best-selling book. Britain was pictured as being inundated with German machines, tools, household goods, and even children's toys." Several years later another book entitled The American Invaders reemphasized the concern about British decline. ${ }^{7}$

In August 1896, the Board of Trade, under the leadership of Charles Ritchie, undertook a detailed study comparing Britain with its principal competitors. This report, which focused on France, Germany, and the United States, concluded that Britain was still ahead of the United States and Germany in its "power for manufacture of export," but the two competitors were gaining ground and were experiencing faster growth. Even more troubling, was the finding that, barring the outbreak of war, Britain's competitors were likely to continue to continue their

\footnotetext{
${ }^{7}$ Friedberg, The Weary Titan: Britain and the Experience of Relative Decline, 1895 - 1905, 37-38.
} 
ascendance and Britain's relative position would continue to come under increasing pressure. It was foreseeable that a structural change in the international system was in the offing.

Nonetheless, what was called for, according to the report, was a redoubling of British effort, and if that were to materialize, Britain would be able to keep up. ${ }^{8}$

\section{$\underline{\text { United Kingdom vis-à-vis Japan }}$}

Between 1860 and the early 1930s, Britain also declined vis-à-vis Japan. The relative decline of British power leveled off during the Second World War, and even climbed towards the end of the war and the defeat of Japan. However, after the war, British relative power once again began to decline as Japan recovered from the war. By 1962, Japan was in a dominant position over Britain. See Figure 4.3 below.

\section{Figure 4.3}

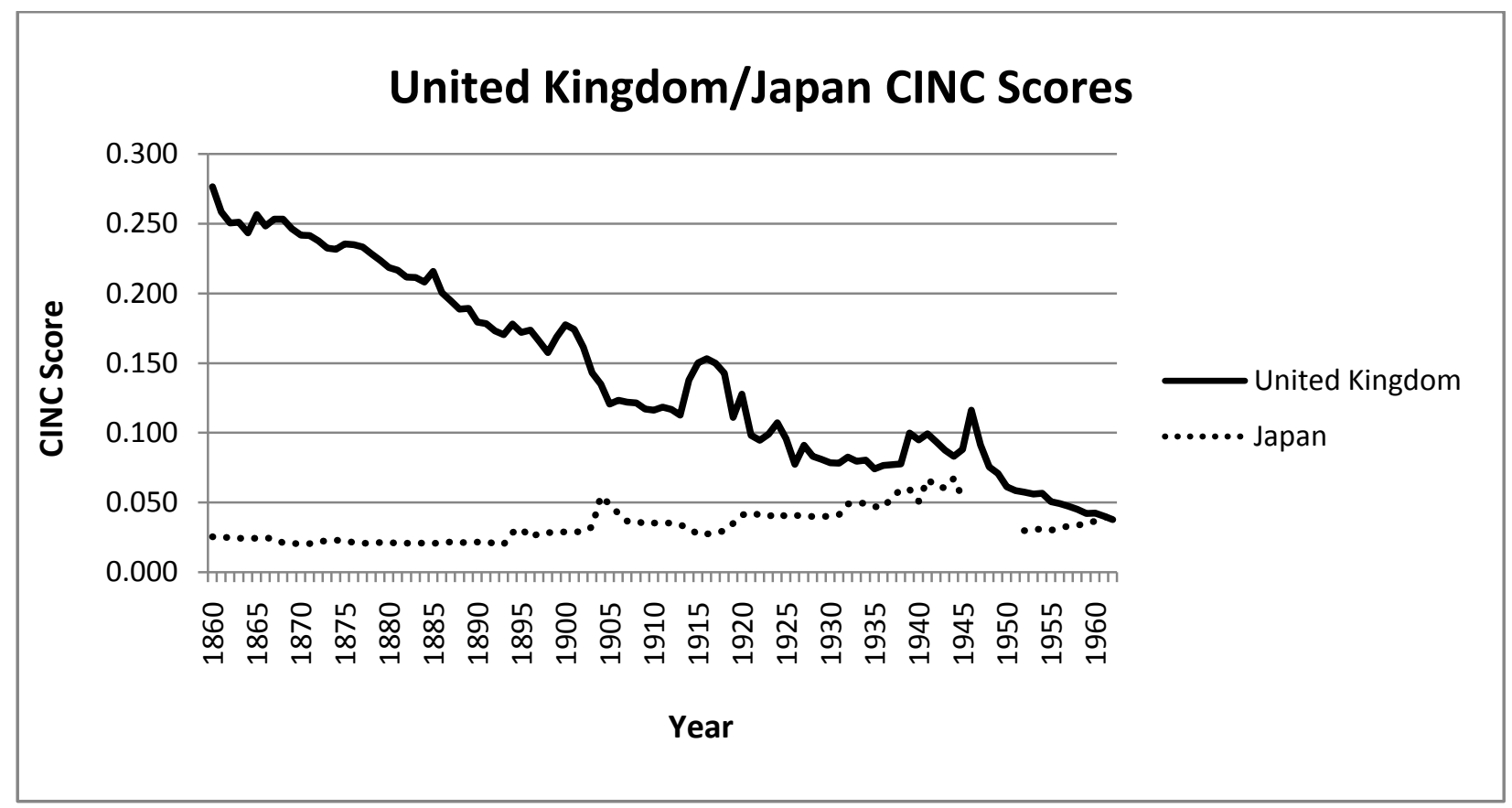

\footnotetext{
${ }^{8}$ Ibid., 47-50.
} 


\section{United Kingdom vis-à-vis Russia/the Soviet Union}

Russia also posed a challenge to Britain, particularly in the area of Indian security.

Russia's CINC score first matched or exceeded that of Britain in 1905 and 1906. Britain and

Russia continued to trade places as the dominant power between 1907 and 1926. At times,

Britain would be dominant, at other times Russia would be in the superior position. By 1927 , however, Russia gained dominance over Britain and never relinquished the lead. See Figure 4.4 below.

\section{Figure 4.4}

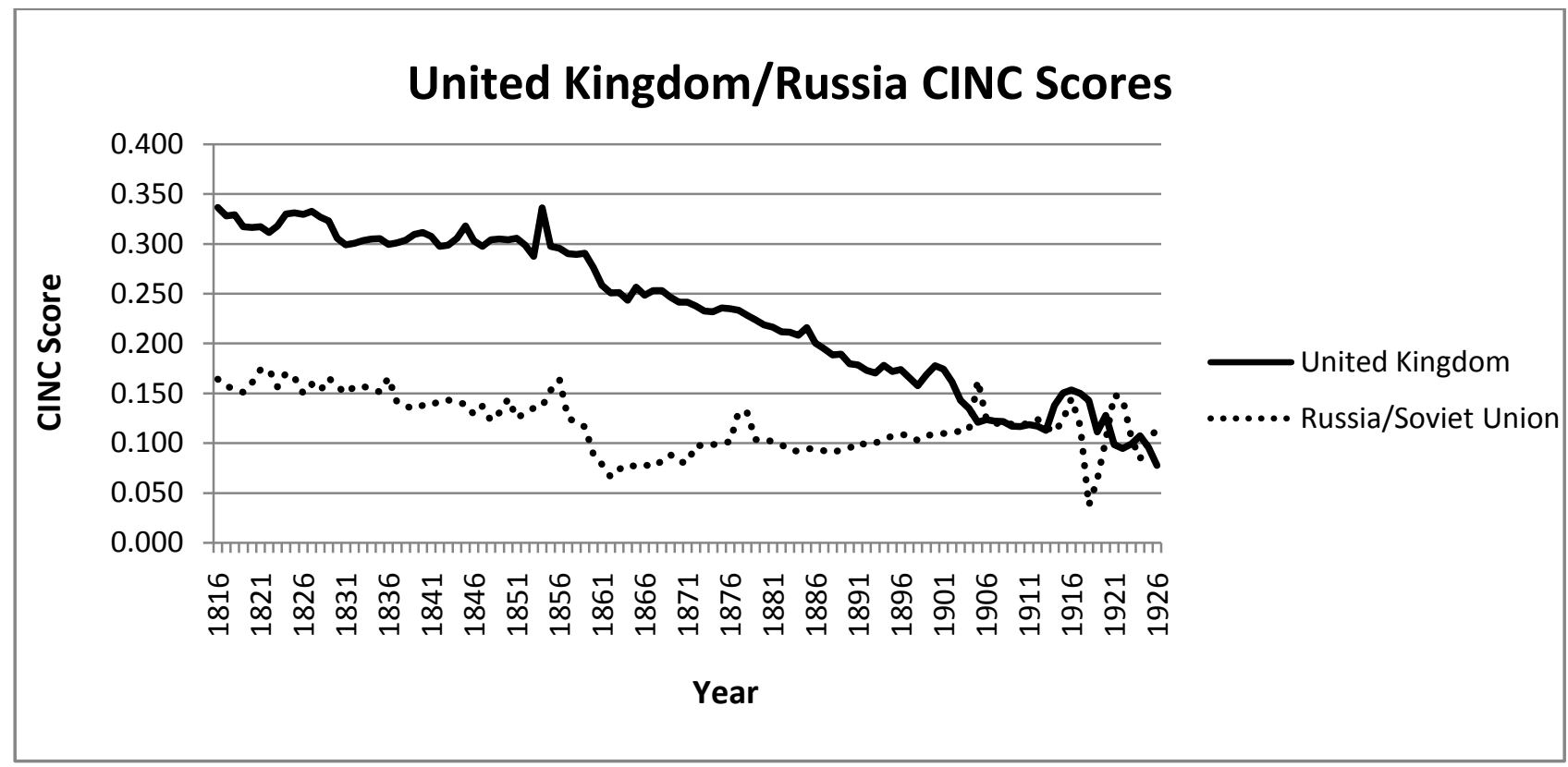

This chapter examines the following instances in which the United Kingdom was in a dominant but relatively declining position in relation to the challenger:

UK/German relations: $1816-1914$

UK/Japan relations: 1860-1914

UK/Russia relations: 1816-1914

UK/United States relations: 1816-1896 


\section{Nature of the Threat}

British decision makers often viewed the threat to Britain on two general planes: economic and military, with the latter focusing on naval power. In this chapter, I examine the extent to which these threats weighed on British decision makers, and the impact these perceived threats had on foreign policy outcomes. ${ }^{9}$

\section{Economic Threats}

As early as the 1840s, some segments of the British government and the general public became concerned that the future did not look as bright as the past, and that Prussia in particular posed an economic threat. A select parliamentary committee on "Import Duties and the Exportation of Machinery” was concerned about Prussian efforts to imitate British machines. Later, in 1856, a pamphlet titled The Darkening Cloud called attention to Britain's growing dependence on foreign sources of food and its tendency to import more than it exported. ${ }^{10}$ For the most part, these initial warnings of decline were dismissed.

Despite these early forebodings, the message from the government was often ambivalent. For example, an 1885 report by a royal commission on the "Depression of Trade and Industry" provided a mixed picture of the future. On the one hand, the commissioners seemed resigned to a measure of inevitable relative decline:

We cannot, perhaps, hope to maintain, to the same extent as heretofore, the lead which we formerly held among the manufacturing nations of the world. Various causes contributed to give us a position far in advance of other countries, which we were able to hold for many years; but those causes could not have been

\footnotetext{
${ }^{9}$ Land forces were considerably less important than naval posture in British strategic planning. Planners were, however, concerned with a possible threat by Russia to India via an invasion through Afghanistan. They were also concerned about the possibility of losing Canada in a war with the United States. Still, the focus of planning was naval, and so I have emphasized that in my research. See Friedberg, 97-98.

${ }^{10}$ Friedberg, The Weary Titan: Britain and the Experience of Relative Decline, 1895 - 1905, 33-34.
} 
expected to operate permanently, and our supremacy is now being assailed on all sides. $^{11}$

On the other hand, there was continued official optimism about trade and economic conditions despite the ongoing battle in the press and Parliament between those who favored free trade and those who proclaimed the necessity of fair trade. The 1885 report suggested that Britain was getting wealthier despite the fact that profits and agricultural prices were falling. Britain's export trade was increasing, even if not as rapidly as that of some of its rivals. Despite the fact that Britain would inevitably decline relative to other countries, it could still be expected to improve absolutely. The committee suggested, "We have still the same physical and intellectual qualities which gave us so commanding a lead; and we see no reason why, with care, intelligence, enterprise and thoroughness, we should not be able to continue to advance."12

While there was no consensus that the status quo would continue to worsen, the debate of whether the status quo was deteriorating centered on two primary groups of leaders. One group favored free trade, even if trading partners sometimes cheated, while the other group wanted fair trade. For the latter group, free trade that drove Britain into debt was no bargain. These advocates of fair trade argued that laissez faire policies were hurting the trade balance of Britain; and they worried that very large powers like the United States and Russia would eventually eclipse Britain. In August 1877, the Bradford Chronicle and Mail lamented "our trade with America has fallen... and with Germany the fall is, if anything, greater.... Unless the nations of Europe and the United States can be induced to treat with us on fair terms...our foreign trade, as

\footnotetext{
${ }^{11}$ Quoted in Ibid., 40. Colonial Secretary Chamberlain also saw in the available evidence a clear picture of a Britain in relative decline. He believed that it was essential that Britain protect her trade against those states that were taking advantage of the policy of free trade. See Friedberg, The Weary Titan: Britain and the Experience of Relative Decline, 1895 - 1905, 57.

${ }^{12}$ Quoted in Friedberg, The Weary Titan: Britain and the Experience of Relative Decline, 1895 - $1905,40$.
} 
regards Bradford, is doomed to decay."13 Similarly, an 1888 report by the Board of Trade claimed that, between 1875-1877 and 1884-1885, British exports had increased 8 percent while those of Germany had risen 16 percent and those of the United States had risen 35 percent. $^{14}$

Herbert Asquith, the Liberal MP and future prime minister, argued that the U.S., Germany, and other industrializing nations would inevitably develop their resources and supply their own domestic needs with their own manufactures. This was, in his opinion, only natural. ${ }^{15}$ He even went so far as to reassure other nations that Britain was a benign power by stating, "We do not covet any people's territory, we have no desire to impose our rule upon alien populations. The British Empire is enough for us." "16 Meanwhile, Lord Roseberry scoffed at those who warned that Great Britain was not rising as fast as Germany and the United States. He argued, "Well, they began with very little. You could not expect to keep the monopoly of the trade of the world, because their populations swelled, and as their energy developed they naturally demanded a share of the trade of the world, as you ought to be pleased and proud that you have kept your position as well as you have."17

The most ardent of the fair traders, Colonial Secretary Joseph Chamberlain, saw in the available evidence clear signs that Britain was declining, but he questioned the inevitability of the rise of the superstates. Chamberlain argued, "When we...talk of the prosperity of America and Germany, [our opponents] say, 'yes, that is natural. Are they not greater than us, are they not more numerous?' Then, in a sort of despairing fatalism they seem to say, 'What can our little England do but fall a victim to the inexorable decrees of fate?"' Chamberlain argued that this

\footnotetext{
${ }^{13}$ Benjamin H. Brown, The Tariff Reform Movement in Great Britain 1881-1895 (New York: Colombia University Press, 1943), 10-11.

${ }^{14}$ Friedberg, The Weary Titan: Britain and the Experience of Relative Decline, 1895 - 1905, 35-45.

15 Ibid., 74.

${ }^{16}$ T.G. Otte, ed., The Makers of British Foreign Policy: From Pitt to Thatcher (London: Palgrave, 2002$), 16$.

${ }^{17}$ Friedberg, The Weary Titan: Britain and the Experience of Relative Decline, 1895 - 1905, 74.
} 
was fatalistic and false logic. He did not see Britain's decline in crucial sectors as either inevitable or natural. He argued, "When I see these industries not leaving us because we are no longer capable of attending to them, but filched from us, stolen by unfair means, then I ask you...How long are you going to take it lying down?"18 He suggested that Britain could strengthen its ties with its empire and could escape the decaying situation. ${ }^{19} \mathrm{He}$ advocated free trade within the empire, but argued that there should be protection from outside states. He also suggested that close cooperation with Germany might be possible, but negotiations along these lines eventually broke down. ${ }^{20}$

Not surprisingly, the free traders disagreed with Chamberlain's assessment and remedies. They believed that protection in any form was bad. Where Chamberlain saw indications of decline, the free traders in the cabinet and the various bureaucracies of the government searched for signs of hope or at least indications that decline was the result of natural forces beyond the reach of governmental policy. Instead of protectionism, they proposed the same solutions that had been on the table since at least the 1880 s_ "better education, better training, better methods, larger outlook.",21

Other free traders disagreed with Chamberlain's overall assessment. The Duke of Devonshire, for example, warned against, "making a new departure, uncalled for by any existing evils, but based solely on abstract arguments as to evils which may possibly come into existence in the future." Nor did Robert Giffen, the chief of the Board of Trade's statistical department, accept the evidence used by the advocates of fair trade or their conclusions. Giffen claimed, "There is no weakening in the hold of the United Kingdom (in comparison with its chief

\footnotetext{
18 Ibid., 74-75.

${ }^{19}$ Ibid., 76.

${ }^{20}$ A.W. Ward and G.P. Gooch, The Cambridge History of British Foreign Policy 1783-1919, 3 vols., vol. III (New York: The Macmillan Company, 1922), 257.

${ }^{21}$ Friedberg, The Weary Titan: Britain and the Experience of Relative Decline, 1895 - 1905, 57, 76.
} 
competitors) upon either the import or the export trade of the world." While he acknowledged that the costs of ruling Britain and the empire increased in the years before 1900, he argued that the gross national product of Great Britain also grew substantially during this time. It appeared to him that the rate of overall economic growth was close to the rate at which spending increased. The cost of ruling the empire was not, in his opinion, overly burdensome. As a result, he viewed any possible move toward protection as potentially harmful to British interests. ${ }^{22}$

Additionally, the free traders at the Treasury Department manipulated the price indexes in such a way that they were able to argue that Britain was in a more advantageous position than might otherwise appear. For example, by comparing trade figures from 1882 with those of 1902, and measuring them in constant 1882 prices, imports rose by 56.6 percent, but exports were also up by 39.4 percent. This presented only a slightly negative picture, certainly nothing to cause national panic. The Treasury Department's analysts also saw significant improvement in almost every other economic sector including individual savings and overall coal consumption. ${ }^{23}$

In addition to concerns about trade, some British official were also troubled about government spending. Michael Hicks Beach, the Chancellor of the Exchequer, in his fourth budget speech in the spring of 1899 , complained about the growth of spending in civil and social services. However, he was forced to admit that the largest increases had come in the area of defense, which he blamed on the "increased and increasing armaments of other nations." 24

While Hicks Beach claimed that Britain was reaching its limits in terms of national financial power, Joseph Chamberlain argued that the limits had not yet been approached. He argued that spending was relatively light compared to the darkest days of the struggle against Napoleon. Furthermore, Britain's burdens were also relatively light compared to its competitors.

\footnotetext{
${ }^{22}$ Ibid., 36-91.

${ }^{23}$ Ibid., 59-60.

${ }^{24}$ Ibid., 105.
} 
"I confess that you alarm me," Chamberlain wrote in response to Hicks Beach. "No doubt the normal expenditure on the Army and Navy has been enormous, but has it been more than is necessary — having regard to what other nations are doing?" The colonial secretary argued that the navy must remain inviolable and the army should only be cut once revised decisions about imperial defense requirements had been reached. Chamberlain argued that tax burdens were not as heavy as was commonly assumed, and that the public would be willing to sacrifice further to ensure the security of the empire. He felt that public opinion and competition from other countries would require some increases in defense spending in the short term. His predictions proved correct as the ministers prepared their budgets for the coming fiscal year. ${ }^{25}$

Hicks Beach was not convinced by Chamberlain's analysis. Hicks Beach believed that the populace would not tolerate any more taxes. He argued, "It is true that our present burthens are light, considering the increase of population and wealth, compared with those borne by our ancestors one hundred years ago. But they were engaged in a life-and-death struggle with France; we, on my assumption, will not be at war at all: the cases do not admit of comparison." In his view, financial ruin and political unrest was inevitable unless the rate of growth of spending could be cut. He suggested that the rate of growth in naval spending had been excessive and could "be lessened with perfect safety." He also argued in favor of inducing the colonies to "take their share in the Naval Defense of the Empire." Furthermore, he believed that army efficiency could be increased and thus the size of the army could be reduced without losing any effectiveness. This in turn, would result in a cheaper standing army. In his final analysis, Hicks Beach proposed cutting defense spending once the Boer War was over. ${ }^{26}$

\footnotetext{
${ }^{25}$ Ibid., 111-14.

${ }^{26}$ Ibid.
} 
Charles Ritchie, Chancellor of the Exchequer after July 1902, largely agreed with Hicks Beach's assessment. For Ritchie and his fellow free traders, long-term industrial decline was not as much of a danger as protectionism. In his view, reducing taxes was the best way to return to sound financial practices. In order to do this, and not run up additional deficits, he acknowledged that existing spending programs would need to be cut. However, Ritchie argued that Britain could not safely cut its own naval fleet while other countries were busy adding to their fleets. ${ }^{27}$ It became clear that the ax would fall first on the army.

As has been alluded to earlier, in addition to the battles over trade policy and governmental spending, the Boer War was seen by some as driving Britain into dire fiscal straits. Yearly budgets were showing massive deficits instead of the usual surpluses. A feeling of fiscal constraint was particularly pressing for the Conservative Unionist government that held power from 1900 to 1905 . The specter of excessive governmental spending loomed over decisions about alliances and the organization and deployment of the army and the navy. ${ }^{28}$

Tax rates were raised between 1899 and 1902 in response to emergency spending. There were also warnings by Michael Hicks Beach and others that the finances of Britain were in crisis. They argued that the nation's financial difficulties predated the beginning of the Boer War and would persist even once hostilities were concluded. In their view, the existing tax system could not fund steadily expanding peacetime expenditures. Joseph Chamberlain and a few others who continued to defend further increases in spending were now decisively outnumbered. A new consensus emerged in the wake of the war that Britain had reached the limits of its financial resources. $^{29}$

\footnotetext{
${ }^{27}$ Ibid., 118-19.

${ }^{28}$ Ibid., 90-91, 106. For an in-depth discussion of British finances and the source tables for much of this discussion see Bernard Mallet, British Budgets 1877-88 to 1912-13 (London: Macmillan and Co., Limited, 1913).

${ }^{29}$ Friedberg, The Weary Titan: Britain and the Experience of Relative Decline, 1895 - 1905, 130-31.
} 
Eventually, key British political leaders like Arthur James Balfour and Joseph Chamberlain's son Austen, who became Chancellor of the Exchequer in 1903, came to believe that larger budgets, accompanied by higher taxes, would inevitably harm the economy. A weakened economy would ultimately reduce Britain's ability to raise large sums of money in an emergency. Political opposition from either the rich or the poor and perhaps from both was also seen as a possibility. Despite this logic, taxes were increased but still failed to match expenditures. Increased defense spending and expanding social spending were simply too much for a balanced budget. ${ }^{30}$

By the turn of the century, the debate had moved on to tariff reform. From 1860 to 1932 , American tariffs were at extremely high levels. Thanks to Britain's willingness to allow American goods reasonably free access to its market without reciprocity, the United States enjoyed a free ride in terms of international trade. This finally ended when Britain responded to the American Smoot-Hawley Tariff by raising reciprocal tariffs against American goods. ${ }^{31}$

From 1903 to 1905, the Conservative party and the country as a whole became embroiled in an increasingly bitter debate over tariff reform. In July 1903, the economist Percy Ashley wrote that Britain's exports were "almost stationary." He claimed that the commerce of Britain had suffered because of foreign tariffs and the industrial development of other countries. Still, Ashley concluded, "Taking such indices as we have, the capital of the country is not declining." He believed that the nation was growing more dependent on banking than on manufacturing, but "if scientific and industrial ability remains [in] the country, new industries will develop." 32

\footnotetext{
${ }^{30}$ Ibid., 92, 111-12.

${ }^{31}$ Walter Russell Mead, Special Providence: American Foreign Policy and How It Changed the World (New York: Routledge, 2002), 109.

${ }^{32}$ Friedberg, The Weary Titan: Britain and the Experience of Relative Decline, 1895 - 1905, 63-69.
} 
In August 1903, Prime Minister Balfour declared that foreign protectionism was to blame for the declining British economy. He argued that the nation's economy might be holding steady at present, but he suggested that there was little reason to think that it would continue to do so. He proposed imposing retaliatory tariffs with the hope of gaining concessions from offending trading partners. ${ }^{33}$

Alfred Marshall, one of Balfour's consultants, agreed with Balfour's conclusions that tariffs by foreign nations were hurting Britain's trade. He also suggested that the expansion of exports had slowed in recent years. He argued that in the future, Britain could not be "the leader but she may be $a$ leader." Marshall viewed as inevitable the loss of some of Britain's earlier advantage. He believed that the best way to keep Britain in the top tier of nations was to promote free trade with Germany and the U.S. ${ }^{34}$

Joseph Chamberlain's son, Austen, took over the office of Chancellor of the Exchequer in 1903. In Chamberlain's view, the financial resources of the United Kingdom were inadequate to provide for imperial defense. Civil spending would need to be frozen and defense budgets would need to be cut. He insisted that both the army and the navy share in the cuts that were now seen as unavoidable. "It is with great reluctance," he wrote, "that I suggest any curtailment of expenditure on the navy; but it would seem clear that we cannot obtain from the army alone all the relief that we require." By December 1903, Austen Chamberlain and Lord Selborne agreed that naval spending would go up by only $£ 2$ million in 1904 . However, this compromise was abandoned by the end of the year when the Admiralty made a sudden request for two additional

\footnotetext{
${ }^{33}$ Ibid., 64-68, 72.

${ }^{34}$ Ibid., 64-65.
} 
battleships. Nonetheless, by 1905 naval expenditures dropped from £41.0 million to $£ 37.2$ million. $^{35}$

Balfour and his fellow Conservatives chose a time-honored method of dealing with financial distress—-spending cuts designed to bring budgets back into balance. Defense spending was still seen as abnormally and unnecessarily high two and three years after the close of the Boer War. Conservatives were also concerned about the new social and political forces that were increasingly determining the shape of domestic politics. They preferred the danger of military disaster overseas to certain electoral defeat at home. ${ }^{36}$

The drive for economy had a significant influence over the empire's defensive posture. Between 1904 and 1906, the spending on the army was reduced from $£ 31.6$ million to $£ 29.1$ million. Chamberlain's luck with the army was somewhat better. As hostilities in South Africa drew to a close, the budget for ground forces was reduced. In 1901-1902 total expenditure on the army stood at $£ 94.2$ million. By the next year, the figure was $£ 70.2$ million. It fell to £39.6 million in 1903-1904. Chamberlain wanted even more cuts, perhaps to the pre-war level of around $\$ 20$ million. ${ }^{37}$

One of the problems that confronted both free traders and fair traders in determining relative decline was that, as Friedberg argues, there was "no reliable way of estimating growth rates or comparing overall economic capabilities across national boundaries.” This made judging relative decline difficult. Had decision makers been able to use an index that estimated spending as a share of gross domestic product, such estimates would have indicated that while outlays had increased dramatically, the economy of Britain had also grown substantially. By the turn of the

\footnotetext{
${ }^{35}$ Ibid., 121-28. See also Mallet, British Budgets 1877-88 to 1912-13, 502-04.

${ }^{36}$ Friedberg, The Weary Titan: Britain and the Experience of Relative Decline, 1895 - 1905, 133-34. See also Mallet, British Budgets 1877-88 to 1912-13, 494-505.

${ }^{37}$ Friedberg, The Weary Titan: Britain and the Experience of Relative Decline, 1895 - 1905, 122-27. See also Mallet, British Budgets 1877-88 to 1912-13, 504.
} 
century the burden of government spending had grown heavier, but the picture was not nearly as bleak as absolute expenditure figures seemed to suggest. Armed with this type of information, Giffen and Chamberlain might have been more successful in easing their contemporaries' anxieties. Without this type of index, it was probably inevitable that absolute spending figures would dominate discussions of the nation's finances. As budgets grew, so too did fears of impending fiscal catastrophe. ${ }^{38}$

Because of the optimistic reports and despite a growing feeling of unease about Britain's relative economic decline, no responsible politician was willing to challenge openly the country's faith in free trade. The Government's free traders in the cabinet and the various bureaucracies looked for signs of hope or at least for evidence that what was happening was the inevitable result of the operation of natural forces. Therefore, even though there was evidence showing that Britain's opponents were growing faster than it was, Britain reacted in a fragmented and only partially coordinated way. There was not enough evidence to convince the vast majority of politicians to move away from the ideal of free trade, and no real change in governmental policy was forthcoming. ${ }^{39}$

Since there was no decisive evidence of relative decline, neither side was able to win the intellectual or policy debate regarding Britain's future. The participants of the debate were largely able to revert to their preexisting beliefs about what was best for Britain and for themselves, and to interpret what evidence there was through the prism of those beliefs. Since the free traders had dominated the political landscape before the debate, an intellectual stalemate amounted to a victory for the free traders. The status quo would continue. ${ }^{40}$

\footnotetext{
${ }^{38}$ Friedberg, The Weary Titan: Britain and the Experience of Relative Decline, 1895 - 1905, 42-129.

${ }^{39}$ Ibid., 19, 42-45, 50-51, 57-59. See also Brown, The Tariff Reform Movement in Great Britain 1881-1895, 60-63.

${ }^{40}$ Friedberg, The Weary Titan: Britain and the Experience of Relative Decline, 1895 - 1905, 82-83.
} 


\section{Military Threats}

Perhaps even more troubling than the long-term possibility of economic decline was the threat of the loss in the short term of outright naval supremacy. In the mid-nineteenth century, the Royal navy consisted of over 240 ships, crewed by more than 40,000 sailors. It was the largest navy in the world by far. Niall Ferguson argues, "At no other time in history has one power so completely dominated the world's oceans, as Britain did in the mid-nineteenth century." ${ }^{41}$

The doctrine of the navy held that its principal mission was control of the seas. In time of war, this would require the prompt engagement and destruction of all enemy forces. As a consequence of this doctrine, the key to naval success rested upon the concentration and rapid mobility of British naval forces. Any unnecessary dispersion of the navy, such as to sooth colonial anxieties during peacetime or to protect colonial shores in war could hamper the navy's primary mission. ${ }^{42}$

At the end of the nineteenth century, maintaining parity with the French and Russian navies was becoming an increasingly costly undertaking. The emergence of a strong German fleet raised the possibility that the traditional two-power standard, in which Britain maintained naval forces equal to its next two competitors, might not be enough to ensure British control of European waters. Finally, the growing capabilities of the American and Japanese navies meant that even a firm grip on European waters was no longer a guarantee of worldwide command of the seas. As a result, some of Britain's outlying interests and possessions could not be considered as secure as they once had been. ${ }^{43}$

\footnotetext{
${ }^{41}$ Ferguson, Empire: The Rise and Demise of the British World Order and the Lessons for Global Power, 138-41.

${ }^{42}$ Friedberg, The Weary Titan: Britain and the Experience of Relative Decline, 1895 - 1905, 117.

${ }^{43}$ Ibid., 168.
} 
A member of the British parliament suggested at the time of the First Hague Conference in May 1899, "The United States, Great Britain and possibly Japan should make their combined naval power so absolutely supreme that they could order the other naval Powers to sell out their ships. Should they refuse, their vessels would be captured on leaving port. That would settle the peace of the world." At the same time, at least one British service journal also advocated the idea of a preventive war to check naval competition. Within British naval circles, there was a fair amount of unguarded talk about preventive war. Alfred Vagts quotes one member as telling the German naval attaché that at present Germany possessed only a few ships, which the British Navy could easily dispose of, "but in a few years you might be strong and we would lose too many of our ships...."44 Britain would eventually find itself faced with naval opposition both from Europe and further abroad.

**Continental Powers**

In 1817, Foreign Minister Castlereagh articulated the policy that would govern British Naval policy for the next nine decades. He suggested that Britain's goal should be "to keep up a navy equal to the navies of any two Powers that can be brought against us." By the 1830s, there were already concerns that France and Russia would sign a treaty and effectively combine their two fleets in opposition to Britain. Worries about a possible Franco-Russian alliance became more intense in the wake of the Crimean War. An Admiralty minute of early 1858 warned, "When determining upon the number of ships which England should have, it should be borne in mind that the navies of France and Russia may very probably be combined against her." To make matters worse, by the end of the 1870s, the French began a shipbuilding program that

\footnotetext{
${ }^{44}$ Alfred Vagts, Defense and Diplomacy: The Soldier and the Conduct of Foreign Relations (New York: King's Crown Press, 1956), 298.
} 
equaled Britain's in cost. Italy, Germany, and Russia also all increased their naval expenditures at about the same time. ${ }^{45}$

The two expanding empires of Russia and Britain met in the nineteenth century in Central Asia. Beginning in 1879, when the British, for the second time, attempted to invade and control Afghanistan, Britain and Russia conducted the world's first cold war along the North-West Frontier. This continued until $1919 .^{46}$ Despite these increased tensions, both powers came to fear Germany more than they feared each other. As a result, they signed the Triple Entente, an essentially defensive treaty, with France in $1907 .^{47}$

France, Russia, and Germany were seen as probable challengers to British naval supremacy throughout the 1880s. The fear was that France and Germany would sign a treaty and effectively fuse their fleets in opposition to Britain. By 1884, France had nearly as many ships as Britain. If Britain were to face a combined Franco-German fleet, the Royal Navy would face a superior force of battleships and an almost equal number of cruisers. In 1887 and 1888, British naval activity decreased while that of the nation's competitors continued unabated. To complicate matters further, at the beginning of 1888 renewed rumors began to circulate that France and Russia might enter a formal alliance with the goal of driving Britain out of the Mediterranean. $^{48}$

In the spring of 1889, the first lord of the Admiralty, George Hamilton, restated the twopower standard. In a flashback to the ideas of 1817 , he recommended to Parliament a five-year program of construction to build ten battleships, forty-two cruisers, and eighteen torpedo boats. The total price tag was 23 million. Hamilton concluded, "Our establishment should be on such

\footnotetext{
${ }^{45}$ Friedberg, The Weary Titan: Britain and the Experience of Relative Decline, 1895 - 1905, 145-46.

${ }^{46}$ Ferguson, Empire: The Rise and Demise of the British World Order and the Lessons for Global Power, 144.

${ }^{47}$ Norman Davies, Europe: A History (New York: Harper Perennial, 1996), 871.

${ }^{48}$ Friedberg, The Weary Titan: Britain and the Experience of Relative Decline, 1895 - 1905, 146-47.
} 
a scale that it should be equal to the naval strength of any two other countries." In particular, Hamilton was referring to "the newest type and most approved design" of battleships. ${ }^{49}$

Though it never stated so publicly, from the beginning the Admiralty had its eye on a possible Franco-Russian alliance. Fortunately for Britain, geography prevented the French and Russian fleets from combining with ease. The hopes of the British navy were pinned on a strategy of destroying its opponents as they moved out of ports on the Baltic and Atlantic coasts and attempted to come together at sea. Furthermore, as long as a Franco-Russian alliance was the worst thing Britain had to fear, it was reasonable to expect that it could maintain control of the waters surrounding Europe. In essence, no hostile forces would be able to fight Britain on the high seas and would not be able to attack its colonies. ${ }^{50}$

Another threat to Britain would come if more than two European powers combined against Britain. There was a fear that a larger "Continental Coalition" possibly including Germany, could form. These fears were further heightened by the "Kruger telegram" incident in which the Kaiser publicly attempted to mobilize European opposition to British policy in South Africa while threatening privately that England would face a "Continental League" if it did not sign a treaty with Germany. At the turn of the century, Germany did in fact emerge as Britain's single most dangerous naval threat. ${ }^{51}$

Beginning in the mid 1880s, Britain became more concerned about the Franco-Russian threat and had to work harder just to keep up. There was a fear that Britain could be eclipsed by the combined naval forces of France and Russia. The British were also concerned that the French and Russians would interfere in British naval operations in the Mediterranean. In the late 1880s

\footnotetext{
${ }^{49}$ Ibid., 147-48.

${ }^{50}$ Ibid., 151. See also A.J.P. Taylor, The Struggle for Mastery in Europe 1848-1918 (New York: Oxford University Press, 1954), 325-45.

${ }^{51}$ Friedberg, The Weary Titan: Britain and the Experience of Relative Decline, 1895 - 1905, 153-56. See also Taylor, The Struggle for Mastery in Europe 1848-1918, 325-45.
} 
and early 1890s, there were signs that both the Russians and French were increasing the size and improving the quality of their fleets. In August 1891, France and Russia entered into a formal entente. Though this stopped short of outright military alliance, it was still disconcerting to British naval observers. Then, in October 1893, Franco-Russian solidarity peaked when a Russian squadron arrived at the French port of Toulon. ${ }^{52}$

In December 1893 the Conservative opposition in Parliament, including Joseph Chamberlain, accused the Government of doing nothing about an increasingly unfavorable naval balance in vital strategic areas. Chamberlain, arguing that the two-power standard might be antiquated suggested, "It may be that a better formula would be...that for any three battleships built by any naval combination against this country we should build five, and that for every cruiser built by the same combination we should build two." 53

The Liberal leadership, however, stuck to the two-power standard. At the time of the Toulon visit, naval intelligence warned that if there were no change in the pace of naval building, Britain would lose its two-battleship advantage over France and Russia within two years and would instead stand at a three-ship disadvantage. By 1896-1897, the disadvantage could grow to as wide as eight capital ships. In early 1896, Salisbury's advisers warned him of increasing Russian naval activity in the Pacific. ${ }^{54}$

In the face of these concerns, First Lord of the Admiralty Spencer proposed a substantial increase in planned construction. Prime Minister William Gladstone resisted this plan, but after the Prime Minister's hasty and forced retirement, a smaller version of Spencer's plan was adopted. This new building program ultimately included nine new first-class battleships. This

\footnotetext{
${ }^{52}$ Friedberg, The Weary Titan: Britain and the Experience of Relative Decline, 1895 - 1905, 153-54.

${ }^{53}$ Ibid., 155.

${ }^{54}$ Ibid., 155-66. For a broad overview of this period see Taylor, The Struggle for Mastery in Europe 1848-1918, $372-76$.
} 
building spurt ensured that Britain would maintain a slight numerical edge over the combined forces of France and Russia. ${ }^{55}$

Other decision makers saw trouble elsewhere. Sir Charles Dilke, a navalist in Parliament, cautioned that existing plans did not adequately address the new threat posed by a rising Germany. He argued that the Government had two options: it could either enter into an alliance with some other state (a measure that he opposed), or it could follow "the only true policy of this country...keeping up such a fleet as would make us safe against any probable combination."

Over the next two years, Dilke continued to criticize the government's building plans. He argued that a three-power coalition was always possible. He also warned that there was growing evidence that increasingly effective French and Russian mobilization procedures were increasing the danger of surprise attack. ${ }^{56}$

Other British policy makers did not agree with Dilke's assessment. First Lord Goschen criticized Dilke's position on the grounds that it was a proposal that suggested Britain "must have a Navy as large as all the navies of the world combined." Goschen dismissed this idea as “preposterous." He answered Dilke's warnings by arguing that the nature of a coalition with its ships of varying design and capabilities could never defeat the navy of a single nation, even if the opposing fleets were equal in size. Any advantage gained by superiority in numbers would be nullified by the problems of coordination. Arthur Balfour also dismissed Dilke's scenario as "the extreme case" and argued that while the combined French-Russian fleet looked formidable on paper, most of their battleships were not capable of operating very far from their homeports. He

\footnotetext{
${ }_{55}^{55}$ Friedberg, The Weary Titan: Britain and the Experience of Relative Decline, 1895 - 1905, 155-56.

${ }^{56}$ Ibid., 156-57.
} 
informed the House that by 1898 , Britain would enjoy a five-ship advantage in first-class craft over Russia and France. ${ }^{57}$

In May 1898, figures published in Parliament showed that Britain had fifty-two battleships, France had twenty-seven, and Russia had twelve. The Franco-Russian alliance also had eighteen battleships under construction. Britain only had twelve battleships under construction. This meant that the gap between the two sides would decrease from thirteen to seven. Germany clearly held the balance with seventeen battleships built and five in the process of being built. At the time of the release of these figures, however, no one seemed to pay much attention. $^{58}$

During the summer of 1898, it was announced that the Russians were building six additional capital ships. In response, four battleships and four cruisers were added to the Royal Navy's construction schedule. At the end of 1898, a report from the Director of Naval Intelligence forecast that within six years Britain would have fifty-seven battleships, compared with twenty-five for Russia and thirty-four for France. ${ }^{59}$

The Fashoda crisis, in which Britain successfully faced down France, boosted confidence in the fleet and highlighted the continued importance of sea superiority. Some optimists believed that Britain's rivals would back away from their plans against the country now that it had shown that it was still superior at sea. Other observers saw only a narrow margin between the nation and potentially unfriendly states, an increasingly costly effort to preserve that advantage, and the possibility that German collaboration would upset the delicate balance. ${ }^{60}$

\footnotetext{
${ }^{57}$ Ibid., 157-58.

${ }^{58}$ Ibid., 158.

${ }^{59}$ Ibid., 158-59.

${ }^{60}$ Ibid., 159.
} 
The Boer War only aggravated these fears. During the first months of the war in South Africa, there were persistent reports that the Russians were attempting to draw France and Germany into an alliance against Great Britain. There was also concern that France would take advantage of the relative weakness of the Channel fleet which was supporting operations in South Africa to carry off a surprise invasion of the home islands. ${ }^{61}$ Furthermore, from the British point of view, thanks to the naval law of 1898 and Admiral Tirpitz's plan to build a German North Sea battle fleet, the German navy was fast becoming the Royal Navy's most dangerous rival. $^{62}$

The concern about Britain's ability to maintain its naval supremacy during this time seems to have penetrated to the highest levels of government. Goschen, in 1900, stated, "This great development of naval power which is being made, not only in France, Russia and Germany but also in the United States and Japan. In all directions we see this great increase of naval construction."

Lord Selborne assumed control of the Admiralty toward the end of 1900. First Sea Lord Walter Kerr advised Selborne on 22 October 1900 that estimates showing Britain with a slight lead over its two closest competitors was flawed. These estimates included some vessels armed with obsolete muzzle loading guns. The French were already modernizing their navy with superior breechloaders. Kerr concluded that by 1905 France and Russia would have fifty-seven battleships opposed to fifty-six for Great Britain. Even this estimate included some newer

\footnotetext{
61 Ibid.

${ }^{62}$ Ferguson, Empire: The Rise and Demise of the British World Order and the Lessons for Global Power, 240. The German army also dwarfed Britain's by 124 divisions to ten. In the event of war, Britain could mobilize 733,500 men; the Germans would have 4.5 million. The Conservatives and Unionists felt that conscription was the only way to overcome these disparities in labor. They proposed German style tariffs to help pay for the buildup. The new Liberal government rejected both conscription and tariffs on principle. The Liberal government instead relied on a commitment to match and, if possible, outstrip German naval construction and a continued policy of rapprochement with France.

${ }^{63}$ Friedberg, The Weary Titan: Britain and the Experience of Relative Decline, 1895 - 1905, 159-60.
} 
muzzleloaders in the British front line. Selborne therefore recommended a minimal building program of six additional battleships (the two-power standard plus two additional ships), to be completed by the end of $1905 .^{64}$

Sir Reginald Custance, the director of Naval Intelligence, worried that even this might not be enough. He calculated that by 1907 Germany would have the same number of battleships as Russia. To make matters worse, the German fleet would be concentrated in the North Sea rather than divided between the Black Sea and the Pacific. Custance deduced that "if we are involved in difficulties with any other Nation, and Germany adopts a menacing attitude, it will be necessary to maintain a force in the North Sea sufficient to mask the German fleet. As the German Navy will be at that date a much greater danger to this country than the Fleet of Russia it is thought that in future all our calculations should refer to France and Germany rather than to France and Russia."

Selborne was also concerned about the potential strength and importance of the German navy. He was becoming increasingly aware of an intensified German political hostility toward Britain. By the end of 1902, Selborne was becoming quite anxious about the German threat. He wanted an additional six battleships over and above simple parity with France and Russia. Selborne was convinced that "the great new German navy [was] being carefully built up from the point of view of a war with" Great Britain. ${ }^{66}$

By 1905, the German navy had come to be perceived as a potent and threatening challenger for control of the waters around Europe. The only real alternative to the redistribution of naval forces was therefore an even greater expansion in the Royal Navy's overall size. More battleships and cruisers could conceivably have permitted a buildup close to home while

\footnotetext{
${ }^{64}$ Ibid., 160.

${ }^{65}$ Ibid., 160-79.

${ }^{66}$ Ibid., 184-90.
} 
allowing a larger continued presence in Asia and the Western Hemisphere. However, this was dismissed as economically infeasible. Since prevailing financial assumptions were so strong, the possibility of trying to maintain regional as well as European supremacy was never seriously entertained. $^{67}$

In the wake of the divisive Boer War, the Liberals' enjoyed an electoral victory in January 1906 with one of the biggest election landslides in British history. As they took power, however, the security threat of Germany was looming. In 1907 the Foreign Office official Eyre Crowe, drafted a 'Memorandum on the present state of British relations with France and Germany'. Its bleak message was that Germany's desire to play “on the world's stage a much larger and more dominant part than she finds allotted to herself under the present distribution of material power" might lead it "to diminish the power of any rivals, to enhance her own [power] by extending her dominion, to hinder the co-operation of other states, and ultimately to break up and supplant the British Empire." 68

During this period of intense naval competition, preventive action was also proposed in addition to or in substitution of a British naval buildup. Whether the threats to British naval supremacy were real or merely perceived, the fear that it caused led to the restatement and advocacy of the idea of preventive action by British Navy and Army officers. For example, the British military attaché in Berlin in the 1890s, James Grierson, was convinced that "we must go for the Germans, and right soon, or they will go for us later. A pretext for war would not be difficult to find, and I don't believe that even Russia would stand by them." ${ }^{69}$ In 1895, R.P. Hobson recommended that the British take preventive action against the French to avert the loss of naval supremacy.

\footnotetext{
${ }^{67}$ Ibid., 207.

${ }^{68}$ Ferguson, Empire: The Rise and Demise of the British World Order and the Lessons for Global Power, 239.

${ }^{69}$ Vagts, Defense and Diplomacy: The Soldier and the Conduct of Foreign Relations, 297.
} 
At the time, such proposals found only a small amount of approval in British admiralty circles. Nonetheless, some naval writers adopted the idea and suggested that if "European Powers do not stop the building of warships, an ultimatum should be sent to them by some modern Pitt, and, if not attended to, British fleets should be sent to destroy them in foreign ports and dock yards...."70

First Sea Lord Fisher was also an advocate of preventive war against Germany. For example, he contemplated destroying the German fleet inside the Kiel harbor during the first Moroccan crisis. The ministers of Parliament, both Conservatives and Liberals, allowed Fisher, who was widely respected for his reorganization of the navy, to openly promote his preventive war ideas. The Germans concluded that Fisher meant what he said and that his Government did not disavow him, in spite of some British assurances that "nobody listens to the wild talk of Fisher." 71

Fisher was not alone among British defense officials in his concepts of preventive war. His and King Edward's close friend, Lord Esher of the Committee of Imperial Defence, also supported preventive war. In November 1908, Esher told the French that in case of a Continental war, the British Government "would be led, by the force of things, to intervene.... Germany will be our competitor and rival and, sooner or later, the opposition of our interests will lead us into conflict. Much better that it should come about today while we remain faithful to our policy [of the entente with France] rather than postpone the day it is falling due and thus alienate France and possibly prepare for ourselves terrible reprisals. This would as well be for our fleet an exceptional occasion to annihilate the German fleet before it can become a real menace to us." 72

\footnotetext{
${ }^{70}$ Ibid.

${ }^{71}$ Ibid., 299.

${ }^{72}$ Ibid.
} 
German concerns were heightened in May 1905 when a British admiral was quoted as saying that much as he regarded an Anglo-German war a great calamity, he "would sooner see such a war break out tomorrow than see it (if it really must come) postponed for a series of years when Germany will be stronger by sea and it may be possible for her to obtain an advantage over us." The ongoing Anglo-German naval competition, increasingly burdensome and hence irritating, produced on the British side both proposals for a halt in the race and proposals for preventive action against Germany before it was too late. ${ }^{73}$

Despite these proclamations by some government and military officials, even with considerable backing from the press, there was no broad popular sentiment for preventive war against Germany in 1914 or before. ${ }^{74}$ Government approval for such preventive action was never obtained. There were threats on the far horizon that also required attention.

The Admiralty was also concerned with the possibility of another threat emerging in the form of non-European countries developing significant naval capabilities. It was feared that the development of this latter threat would spread thin the British fleet and would likely require a substantial enlargement of the fleet. Combining this threat with countering a Franco-Russian (and possibly German) alliance would be extremely difficult. At the end of the $19^{\text {th }}$ century and beginning of the $20^{\text {th }}$ century, this nightmare scenario came to pass. ${ }^{75}$

\section{**United States**}

For Great Britain, a rising United States represented a new front on which Britain would have to fight even before the close of the eighteenth century. As the wars of 1779-1783 and 1812-1814 showed, this could be a problematic distraction if British forces were engaged in a

\footnotetext{
${ }^{73}$ Ibid.

${ }^{74}$ Ibid.

${ }^{75}$ Friedberg, The Weary Titan: Britain and the Experience of Relative Decline, 1895 - 1905, 152.
} 
full-scale European conflict. ${ }^{76}$ This would be a theme that would play out over the next century and a half. ${ }^{77}$ Robert Kagan argues, "Except for the need to protect Canada, an increasingly difficult assignment, British policy aimed at appeasing the United States, not challenging it.",78

The United States had allowed its fleet to decay after the Civil War; and as late as the mid 1880s the American fleet was still an insignificant entity, smaller even than the Swedish fleet. However, beginning in the late 1880 s, it began the slow process of rebuilding by embarking on a navy-building program more ambitious than even Germany's. The achievement was incredible, and by 1907 the American fleet was second only to the Royal Navy. By the early 1900s Great Britain recognized the United States as a rival empire serious enough to be worthy of appeasement. $^{79}$

As late as 1889, War Office and Admiralty officials concluded that existing garrisons in North America provided sufficient protection to Britain's imperial possessions in the Western Hemisphere as long as the United States did not increase the size of its navy. The army's planners concluded that no immediate reinforcements were needed at places like Bermuda and Halifax as long as the U.S. navy remained weak. However, the report from the joint conference noted, "The present naval policy of the United States tends in the direction of a considerable increase of strength." ${ }^{80}$

\footnotetext{
${ }^{76}$ Paul Kennedy, The Rise and Fall of the Great Powers (New York: Vintage Books, 1987), 94.

${ }^{77}$ Historian Bradford Perkins suggests: "Many in England [at the time of the American Civil War] came to wonder if a divided [United States], rather than a unified one, might pose a lesser menace to British interests." See Bradford Perkins, The Creation of a Republican Empire, 1776-1865, ed. Waren I. Cohen, IV vols., vol. I, The Cambridge History of American Foreign Relations (New York: Cambridge University Press, 1995), 219. However, these thoughts were not turned into overt action and are not studied here since this falls outside our focus timeframe of 1895-1905. Still, this sentiment may be worth further consideration.

${ }^{78}$ Robert Kagan, Dangerous Nation: America's Place in the World from Its Earliest Days to the Dawn of the Twentieth Century (New York: Alfred A. Knopf, 2006), 302.

${ }^{79}$ Niall Ferguson, Colossus: The Price of America's Empire (New York: The Penguin Press, 2004), 42-43.

${ }^{80}$ Friedberg, The Weary Titan: Britain and the Experience of Relative Decline, 1895 - 1905, 161-62.
} 
By 1890, the United States had three battleships capable of conducting operations along its coasts, and in 1892 a fourth battleship was added to the fleet. The British navy, with its overwhelming naval power, had nothing directly to fear from these developments. The real problem for the British was that there was now the possibility of yet another hostile collaborator against British imperial interests. ${ }^{81}$

In late 1895 and early 1896, Britain and the United States were involved in a dispute over the determination of boundaries in Venezuela. Partly because this crisis coincided with the Kruger telegram incident, the cabinet decided to give way before American pressure, and in so doing, they ceded dominance of the hemisphere to the United States. ${ }^{82}$ Arthur Balfour, the Tory leader in the Commons, declared in January 1896 that Britain had no "forward policy" in South America and that it had "never desired" and did not "now desire, either to interfere in the domestic concerns of any South American State or to acquire for ourselves any territory that belongs to them." He also pleaded for permanent Anglo-Saxon friendship and unity. Fears of Germany and Russia and to perceived vulnerabilities across the expanse of the British Empire helped pave the way from British acquiescence in the Western Hemisphere. ${ }^{83}$

On the first day of 1896, after the worst had passed, Lord Dufferin, former governor of Canada, wrote to Queen Victoria: "Even if peace is assured for the present, America is sure now to set about strengthening her navy; and, when she has a powerful fleet she will be tempted to use it. Consequently...England ought to make herself strong enough to confront not two navies, but three." $" 84$

\footnotetext{
${ }^{81}$ Ibid., 162.

${ }^{82}$ Ibid.

${ }^{83}$ Kagan, Dangerous Nation: America's Place in the World from Its Earliest Days to the Dawn of the Twentieth Century, 373-74.

${ }^{84}$ Friedberg, The Weary Titan: Britain and the Experience of Relative Decline, 1895 - 1905, 162.
} 
Calls for a three-power standard did not, as has been noted, make much headway, whether the presumed third party was Germany or the United States. Nevertheless, in the wake of the Venezuelan scare there was a renewed interest in the defense of the North American portions of the empire. In April the Joint Naval Military Committee agreed that "in the case of war with the United States the safety of Canada could be best ensured...by landing a British force on American territory and making a vigorous offensive movement. ${ }^{.85}$

Increasingly, however, an invasion of the United States was seen as less and less desirable. There were already high-ranking officials in London who doubted both the wisdom and the feasibility of entering into an open and explicit naval competition with the United States. By the end of 1896, some navy officers were warning that they had already lost superiority on the western half of the American continent. On 8 January 1897, Lord Lansdowne, secretary of state for war and future head of the Foreign Office, argued that if Britain tried to keep pace with the United States in the Western Hemisphere, financial ruin would inevitably result. ${ }^{86}$

At the end of 1897, the first sea lord warned that the American government was making "a supreme effort" to strengthen its coastal defenses "as well as to increase the Navy." The Admiralty was rapidly losing whatever stomach it might once have had for a wartime effort to land forces along America's eastern seaboard. The Admiralty for its part was becoming less and less willing to contemplate the possibility of a naval clash with the United States. ${ }^{87}$

The British view of the American navy came into focus in the last couple of years of the $19^{\text {th }}$ century and the first couple of years of the $20^{\text {th }}$ century. During the Spanish-American War, the United States demonstrated the fighting power of its new navy and acquired bases from Spain in the Caribbean and the Pacific. In addition, three more battleships were added to the six

\footnotetext{
${ }^{85}$ Ibid., 162-63.

${ }^{86}$ Ibid., 163.

${ }^{87}$ Ibid., 164.
} 
in service in 1898, another three came online during the next year, and an additional two were ordered in $1900 .^{88}$

Great Britain now faced a serious dilemma. If it were to remain superior off the Atlantic coast of North America, it would need either to redistribute some of its forces in European and Asian waters or undertake an even larger buildup of its own. In February 1899, L.A. Beaumont, the outgoing Director of Naval Intelligence, warned, "the United States mean to be the strongest Naval power [along their eastern coast] and it will be difficult to prevent it." As Custance, Beaumont's successor as Director of Naval Intelligence, would shortly point out, "with Cuba, Puerto Rico and St. Thomas in the hands of the Americans our position in Jamaica and the Caribbean Sea will be precarious, and will be the cause of much anxiety in the event of war with the United States.",89

To make matters even worse for the British, the United States was also pressing for a canal across Central America that would link the eastern and western portions of its fleet and its new “empire." For almost two years, the U.S. and Britain had been involved in sporadic efforts to renegotiate the Clayton-Bulwer Treaty of 1850 . This treaty did not allow either country to build and exert exclusive control over a Central American sea canal. ${ }^{90}$ The treaty reflected the disparity of power between the British Empire and the United States in 1950, but by the end of the nineteenth century, the U.S. government felt it was in a much stronger position. ${ }^{91}$ The United States government wanted the ability to quickly move its growing navy, in order to protect its new possessions in the Caribbean and the Pacific. The British, on the other hand, were dragging their feet in the negotiations precisely to prevent this enhanced American flexibility. The British

\footnotetext{
${ }^{88}$ Ibid.

${ }^{89}$ Ibid.

${ }^{90}$ Ibid., 164-70.

${ }^{91}$ Kagan, Dangerous Nation: America's Place in the World from Its Earliest Days to the Dawn of the Twentieth Century, 305.
} 
were happy with the status quo. However, with the outbreak of the Boer War and their troubles in Europe and the Far East, Lord Landsdowne, the new head of the Foreign Office was much more willing to reach some sort of agreement with the U.S., even if it meant giving in to a number of American demands. ${ }^{92}$

On 5 January 1900, the Admiralty produced a report that suggested that the United States would soon have "a fleet sufficiently powerful to insure to her command of the Caribbean Sea and of American waters on the Pacific Coast. It is difficult to see how Great Britain can prevent this if the latent resources of the U.S. are considered.” The report noted that under existing conditions Britain could still deploy sufficient forces to gain local superiority. Doing so, however, would seriously weaken its position in other areas. The situation was likely to worsen as the United States further utilized its latent power. It was therefore extremely unlikely that the Royal Navy could safely match the Americans on either side of the proposed isthmian canal. The development of a canal would make the task of overwhelming the U.S. fleet even more difficult. A canal would virtually ensure American supremacy off U.S. coasts in wartime. Given the relatively small British deployments there, this condition already prevailed during peacetime. Lord Landsdowne argued that with or without the canal, the American navy would become dominant in the Western Hemisphere. There was little complaint from the admiralty, which had already come to the same conclusion. ${ }^{93}$

The army, on the other hand, since there was no formal treaty with the U.S., continued to hold itself ultimately responsible for the defense of Canada and the manning of the various imperial outposts scattered off the U.S. coast. Canada, with its extended land border, was of special concern to the army. The British army had hoped to deal with the danger of an American

\footnotetext{
${ }^{92}$ Friedberg, The Weary Titan: Britain and the Experience of Relative Decline, 1895 - 1905, 169-70.

${ }^{93}$ Ibid., 170-72.
} 
invasion by planning an amphibious counterattack against the eastern seaboard of the United States. This plan was clearly no longer viable after 1901. As the Admiralty reduced the circle within which most of its forces would operate, it inevitably left the army dangerously exposed in North America. As recognition of the new situation began to dawn, an interagency tussle of major proportions erupted..$^{94}$

On 24 February 1903, the Admiralty spelled out some of the conclusions to which it had come two years before. It predicted that by the end of 1905 the U.S. fleet would consist of twenty battleships and eight armored cruisers. Only a small number would be deployed in the Pacific. This fact, along with the increasing strength of the European Continental Powers, did not bode well for the probability that Britain would be able to blockade the Atlantic portion of the United States' fleet in its own ports. Admiral "Jackie" Fisher went so far as to suggest that the defense of western Canada was "absolutely hopeless [and] that it would be equally hopeless elsewhere..." Fisher's conclusion was that given the weakness of its position, the policy of the British government ought to be to "use all possible means to avoid" a war with the U.S. In any case, "it seems an utter waste of time to prepare for it." In his view, there was little Britain could do to defend Canada if the U.S. was determined to invade. ${ }^{95}$

The decision to acquiesce to an American-built-and-controlled canal committed Great Britain to naval inferiority in American waters and therefore to friendship with the United States. On 6 January 1905, the Admiralty made a formal statement: "The view of the Admiralty is that Canada must primarily rely upon her own resources for defence against invasion by the United States." The Admiralty also warned the Canadian government that it should do nothing by way of preparation that might antagonize the Americans. Appeasement was to be pursued by both

\footnotetext{
${ }^{94}$ Ibid., 184-86.

${ }^{95}$ Ibid., 186-97.
} 
Ottawa and London. For all practical purposes, the British presence in the Western Hemisphere had come to an end. ${ }^{96}$

$* * \operatorname{Japan} * *$

British acquiescence to the United States opened the door to similar actions regarding Japan. A rising Japan was signaled when that island nation defeated China in the spring of 1895, but Japan had been on the move well before then. During the late 1880s, the Japanese began taking the first steps toward acquiring a modern navy. ${ }^{97}$ While the emergence of the United States as a naval power seemed an obvious threat to British interests, the materialization of a strong Japan was a more ambiguous occurrence.

After the defeat of the Chinese, the European powers coerced Japan into surrendering much of what it had gained through combat. In the wake of this humiliation, the Tokyo government vowed to never again be at the mercy of the Europeans and began a substantial naval buildup with plans to construct six battleships and six modern cruisers. In 1896, Brassey’s authoritative Naval Annual pointed out that "the Japanese are already building two powerful battleships in England and have drawn up an extensive programme of shipbuilding, which includes four battleships of 15,000 tons. It is clear that with this new competitor in the field, we cannot hope to hold much longer the prominent position we have hitherto done in the waters of Eastern Asia." 98

In the closing quarter of the nineteenth century, the European powers were competing for influence in the Far East. By 1898, Japan was at least theoretically capable of tipping the naval balance in a war between the European powers. Britain therefore had good strategic reasons to

\footnotetext{
${ }^{96}$ Ibid., 172-99.

${ }^{97}$ Ibid., 161.

${ }^{98}$ Ibid., 165-66.
} 
seek amiable diplomatic relations with Japan and perhaps to encourage the growth of the Japanese armed forces. If Britain regarded Japan as a potential enemy, it would need to either accommodate one or more of the other powers in the region, or increase its forces there unilaterally. If, however, Japan became an ally, the combined fleets of the two "island empires" might be able to take on those of even the largest Continental coalition. Beginning in the early 1870s, English officers acted as instructors to their Japanese counterparts. Furthermore, most of the major ships in Japan's navy were actually built in England until $1900 .{ }^{99}$

At the end of the summer of 1901, the Government was preparing to enter into serious treaty talks with Japan. Britain was concerned with defending its interests in the Far East while at the same time more than matching its likely opponents in European waters. Of primary concern was the fact that Russia's naval strength in Asia had been steadily increasing. ${ }^{100}$

Selborne argued that if Britain entered into a naval alliance with Japan, the combined battleship strength of the two nations in Asian waters would be eleven, two ahead of France and Russia. They would also be assured of a "preponderance of cruisers." Selborne's arguments played an important part in the cabinet's decision to negotiate an agreement with Japan. If Britain wished to remain superior in the Pacific to France and Russia, or even Japan, let alone a coalition of all three, it would need to either weaken itself dangerously in European waters or make substantial increases in overall fleet size. ${ }^{101}$

The Anglo-Japanese treaty was signed on 29 January 1902. It was published several weeks later and committed each country to come to the assistance of the other if it was attacked by two or more hostile powers. A secret clause also called for substantial naval cooperation in times of peace. Britain was thus forced in the opening years of the twentieth century to abandon

\footnotetext{
${ }^{99}$ Ibid., 165-67.

${ }^{100}$ Ibid., 174-76.

${ }^{101}$ Ibid., 177-78.
} 
its traditional diplomatic policy of "splendid isolation." This was a direct result of the deterioration in its relative naval power. ${ }^{102}$

In February 1904, Japan and Russia came to blows. Britain and France had no desire to be sucked into the war by their respective allies. In an effort to avoid such a scenario, Britain and France came to an agreement regarding spheres of influence in North Africa. The agreement ushered in a major improvement in relations between the two old rivals and would eventually lead to a virtual diplomatic and military alliance. ${ }^{103}$

The opening battles of the Russo-Japanese War proved the Japanese to be more than a match for their Russian opponent. Initial naval engagements off Port Arthur left the Russian Pacific fleet badly damaged. By the end of the war, Russia was reduced to the rank of a minor naval power and forced to sue for peace. With the demise of the Russian fleet and more cordial relations with France, Germany was increasingly seen as the principal threat to Britain's control of European waters. For this reason, the concentration of British forces would have to continue. The new organization was made easier by the weakening of Russia's presence in the Far East and by the virtual disappearance of the czar's fleet. ${ }^{104}$

Russia's defeat was a boon for Britain. Before the Japanese victory, England would have been no match numerically for a coalition of France, Russia, and Germany. In the aftermath of the Russo-Japanese War, the Royal Navy could deploy, in the words of Fisher, "a force of battleships considerably superior to the combined battleship strength of those three Powers. Remember, it is the battleship that determines victory.",105

\footnotetext{
${ }^{102}$ Ibid., 167, 80-81.

${ }^{103}$ Ibid., 192.

${ }^{104}$ Ibid., 190-200.

${ }^{105}$ Ibid., 199.
} 
By the end of the Russo-Japanese War, Britain had an alliance with Japan and more cordial relations with France. Russia was no longer a naval threat. Britain had also resolved the puzzle of what to do in the Western Hemisphere by conceding the region to the United States. Germany was still a serious concern, but many Britons were secure in the fact that at least Britain would not be facing a coalition of powerful states should conflict come.

\section{$\underline{\text { Analysis }}$}

In this section, I assess the performance of my Domestic Politics Model of Prevention in predicting the outcome of British policy during the periods under consideration. Following the method of structured, focused comparison, each of the eleven questions posed in chapter three are answered, and then an overview of the model's performance is outlined for each question. The typology for this model appears in table 4.1 while the flowcharts for the individual cases appear in Appendix A. 
Table 4.1: A Typology of Preventive Action

\section{Causal Mechanisms}

\begin{tabular}{|c|c|c|c|c|c|}
\hline & & $\begin{array}{l}\text { Systemic } \\
\text { Structure/ } \\
\text { Polarity }\end{array}$ & $\begin{array}{l}\text { Internal } \\
\text { Power } \\
\text { Constraints/ } \\
\text { Offense vs. } \\
\text { Defense } \\
\end{array}$ & $\begin{array}{l}\text { Domestic } \\
\text { Political } \\
\text { Constraints/ } \\
\text { Pressures }\end{array}$ & $\begin{array}{l}\text { Ruler Belief } \\
\text { Systems/ } \\
\text { Perception of } \\
\text { Threats }\end{array}$ \\
\hline \multirow{4}{*}{ 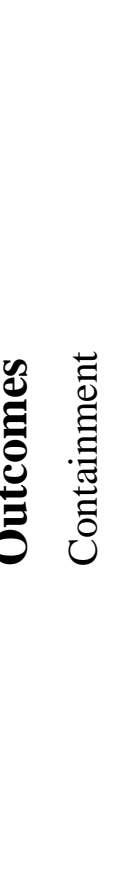 } & $\begin{array}{l}\text { Acquiescence/ } \\
\text { Do Nothing }\end{array}$ & $\begin{array}{l}\text { Bipolar/ } \\
\text { Balanced } \\
\text { Multipolar }\end{array}$ & $\begin{array}{l}\text { Severe/ } \\
\text { Defensive } \\
\text { Strategy }\end{array}$ & $\begin{array}{l}\text { Severe Political } \\
\text { Constraints/ } \\
\text { Pressure }\end{array}$ & $\begin{array}{l}\text { Moderate - } \\
\text { Acquiescent/ } \\
\text { Low - Non- } \\
\text { Militarized }\end{array}$ \\
\hline & $\begin{array}{l}\text { Accommodation/ } \\
\text { Mix of Strategies/ } \\
\text { Carrot and Stick }\end{array}$ & $\begin{array}{l}\text { Bipolar/ } \\
\text { Balanced } \\
\text { Multipolar }\end{array}$ & $\begin{array}{l}\text { Moderate/ } \\
\text { Defensive- } \\
\text { Offensive } \\
\text { Strategy }\end{array}$ & $\begin{array}{l}\text { Moderate } \\
\text { Political } \\
\text { Constraints/ } \\
\text { Pressure }\end{array}$ & $\begin{array}{l}\text { Moderate - } \\
\text { Pragmatic/ } \\
\text { Moderate - } \\
\text { Non- } \\
\text { Militarized }\end{array}$ \\
\hline & \begin{tabular}{|l|} 
Initiate Sustained \\
Coercive/ \\
Confrontational \\
Diplomacy
\end{tabular} & $\begin{array}{l}\text { Bipolar/ } \\
\text { Unbalanced } \\
\text { Multipolar }\end{array}$ & $\begin{array}{l}\text { Moderate/ } \\
\text { Offensive- } \\
\text { Defensive } \\
\text { Strategy }\end{array}$ & $\begin{array}{l}\text { Moderate } \\
\text { Political } \\
\text { Constraints/ } \\
\text { Pressure }\end{array}$ & $\begin{array}{l}\text { Pragmatic - } \\
\text { Militant/ } \\
\text { Moderate - } \\
\text { Militarized }\end{array}$ \\
\hline & \begin{tabular}{|l|} 
Initiate \\
Militarized \\
Preventive Action
\end{tabular} & $\begin{array}{l}\text { Unbalanced } \\
\text { Multipolar }\end{array}$ & $\begin{array}{l}\text { Minimal/ } \\
\text { Offensive } \\
\text { Strategy }\end{array}$ & $\begin{array}{l}\text { Minimal Political } \\
\text { Constraints/ } \\
\text { Pressure }\end{array}$ & $\begin{array}{l}\text { Militant - } \\
\text { Radical/ } \\
\text { High - } \\
\text { Militarized }\end{array}$ \\
\hline
\end{tabular}

1) To what extent is the internal power of the state constrained?

The internal power of Britain was highly constrained between 1900 and 1905 in the wake of the Boer War. Free trade policies also had an impact on government revenue since an absence of tariffs meant no income from imports. Furthermore, deficits during this period limited decision makers' options regarding preventive action toward challengers. This is brought into stark contrast with Hicks Beach's recommendations to cut defense spending. His view that Britain was reaching the limits of its financial resources is important in understanding the ability of the country 
to continue its military buildup. The expenses of the Boer War put further pressure on the finances of the empire. These financial constraints eventually resulted in military constraints.

Using the typology of preventive action, I have developed (see figure 4.1) the UK's internal power constraints and military posture during this period can be classified either as a "Severe/Defensive Strategy" or "Moderate/Defensive-Offensive Strategy". This would suggest that the UK would acquiesce to or accommodate rising powers. This is what we have seen during this period. Particularly when it came to European powers, Britain was much more inclined to a containment policy. In regards to the U.S. and Japan, acquiescence and accommodation were the order of the day.

\section{2) To what extent are pro-preventive action elements constrained?}

As we have seen, though there was talk of possible preventive war against Germany, France, and Russia (particularly in terms of naval matters), this "loose talk" was never transformed into governmental policy. In fact, these discussions were never given serious consideration by most decision makers. Therefore, it is reasonable to conclude that pro-preventive action elements were fairly constrained.

\section{3) What is the nature of the ruler belief system?}

The leadership of Britain during this time can only be labeled as moderate or pragmatic. The latter label seems the most appropriate. This is particularly true when looking at British policymakers decisions regarding naval forces. In this case, British political leaders recognized that British naval power was not sufficient to maintain 
preponderance around the globe; and so they ceded some of that responsibility to the Americans and the Japanese. Since European waters were the priority for British policymakers, this was a very pragmatic decision.

Looking again at the typology in figure 4.1, "Moderate-Acquiescent" and "Moderate-Pragmatic" best describe the ruler belief systems during this period. This would suggest outcomes that square very well with reality. Acquiescence and accommodation are predicted by the DPMP, and that is what in fact occurred.

\section{4) What is the nature of the threat (military, non-military)?}

As early as the 1840 s, Prussia was seen as an economic threat. In the 1870 s and 1880s, the United States and Germany were both seen as economic threats. There was, as has been noted above, a contentious debate about fair versus free trade. There was also talk about retaliatory tariffs (a form of preventive action), but no real action was taken during the period under investigation.

Furthermore, Russia, Germany, and France were all seen as naval competitors. The primary British response to this was a continued naval buildup in an attempt to maintain a favorable balance of power. Over time, however, fleet consolidation in European waters became necessary.

The U.S also posed a threat to the supremacy of the Royal Navy in the Western Hemisphere, but not to the British naval supremacy in the waters surrounding Europe. It became increasingly clear that if Britain maintained parity in the Western Hemisphere it would risk losing supremacy in Continental waters. It was also evident that Canada and other British positions in the Western Hemisphere were becoming 
indefensible. As a result, the British decided to pull back from the region and not attempt to forestall the rise of American regional power. British appeasement of American power, therefore, opened the door to further American expansion.

Japan, like the United States, posed a naval threat on the periphery. Japan could clearly tilt the balance of power in the Far East. It was therefore in Britain's interest to make sure that Japan was on its side in any conflict. War with Japan would have meant sending some of the Royal Navy to the Far East, weakening the British position in some other part of the world. It seemed more expedient to make sure that such a conflict be avoided, and so Britain entered into an alliance with Japan.

On this dimension, the DPMP performs less well. Though the British were not extremely concerned about the threat of Japan and the U.S. to the home islands, their navies still represented a militarized threat in their respective regions. In these two cases, the classification of the situation as "Moderate-Militarized" would probably be most appropriate: suggesting "coercive/confrontational diplomacy." This, of course, did not happen. Britain instead acquiesced to the U.S. in the Western Hemisphere and allied itself with Japan in the Far East. Regarding Continental powers, at least at some points during the period under study, there was a "high-militarized" perception of threat. The typology suggests that under this condition, Britain should have initiated some kind of militarized preventive action. Instead, Britain moved more to contain the Continental powers - alliance with Japan, concentration of naval forces in European waters - than to actively counter their rise with military force or economic embargoes. 


\section{5) To what extent is conflict seen as likely or inevitable?}

Oddly enough, the belief in the inevitability of economic conflict does not seem to have played a major role in the decision making process during this time. The possibility of conflict was often framed in economic and trade terms, and even then it was treated as largely theoretical in nature. Even in terms of tariffs, there was no consensus to use retaliatory tariffs against other states. Prime Minister Balfour, however, did recommend the implementation of retaliatory tariffs. Asquith's statement about the benign nature of Britain exemplifies the belief or hope that conflict was unnecessary.

In examining the naval relations between Russia, France, Germany, and Britain, it is difficult to determine the perception of the likelihood of conflict. However, it is reasonable to assume that conflict was seen as at least somewhat likely since there were crises such as Fashoda and the Crimean War. Unfortunately, the murkiness of this issue causes problems for my model.

Conflict with the U.S. seems to have been thought possible, but less urgent than that of Continental powers. Probably the main reason for this fact is that the U.S. was not a threat to the British home islands themselves. Furthermore, control of the Continental waters was seen as the highest priority, and the U.S. was not perceived to threaten British supremacy there. Similarly, conflict with Japan was not seen as inevitable by British policy makers. It did not even seem likely. Therefore, the decision to enter into an alliance was a fairly easy one for the British. Additionally, the British-Japanese alliance can be seen as a form of preventive action against the Continental powers and perhaps even the United States. By ensuring a strong Japan, 
the British reduced the probability that another power would be able to move into the Far East.

In looking at the typology in figure 4.1, it seems that here again the DPMP falls short of accurately predicting British behavior. For the U.S. and Japan, there was a "moderate" threat of conflict and since this threat had a militarized component, Britain should have, according to the typology, initiated sustained coercive diplomacy with these two powers. On the other hand, regarding the Continental powers, there was a higher threat of conflict that should have at least resulted in confrontational diplomacy and perhaps militarized preventive action. Some of the former did occur, but the latter did not. Therefore, my model does not perform extremely well on this dimension.

\section{6) To what extent do domestic elements believe that a war would not be costly?}

Clearly, conflict between Britain, Russia, Germany, and France would be costly. Furthermore, British decision makers had to contend with the real possibility that any war with any one of these powers would result in a war with all three. Its two-power standard would in no way guarantee victory against these three powers. Therefore, militarized action would have been seen as very costly and possibly catastrophic.

Conflict with the U.S. would have also been expensive. It was widely believed that the United States would be able to invade Canada and take that country regardless

of what the British navy and army did. As the $19^{\text {th }}$ century came to a close and the $20^{\text {th }}$ century dawned, it became increasingly clear that American power in the Western Hemisphere was outstripping that of Britain in the region. Conflict, therefore, would be prohibitively expensive. 
Similarly, a war with Japan would have been costly because it would have created vulnerabilities in other parts of the empire. This cost would have increased if Japan joined a coalition of European powers - particularly France, Russia, or Germany—or any combination of the three. Alliance and accommodation seemed a much wiser course of action to many British decision makers.

The DPMP (see flowcharts in Appendix A) predicts this dimension fairly well. In those instances when militarized preventive action is seen as costly it should be less likely. This was certainly the case with Britain. Even in those instances where it would have been less costly to initiate militarized preventive action sooner rather than later, there was still a great amount of apprehension. This occurred as predicted by my model.

\section{7) To what extent is there the belief that a war now would be less costly than a war later?}

There was clearly the belief by some decision makers, including Lord Esher, that if war were inevitable, it would be better to have it in the short term before Germany fully developed its naval potential. However, as has been noted, British policymakers were extremely cautious. It was clear that any conflict, especially militarized conflict, would present a heavy burden.

Conflict on the periphery was also seen as problematic. War with the U.S. was already seen as prohibitively expensive. Canada would certainly be lost, as would other British positions. By the beginning of the $20^{\text {th }}$ century, war was seen in most corners of British policy making as simply too expensive to contemplate. Similarly, a war with Japan that could possibly involve Continental powers was seen as 
exceedingly costly and dangerous. Acquiescence was a more logical choice from the standpoint of British decision makers. This would also have the added benefit of perhaps freezing other powers out of the Far East.

This again is addressed by the flowcharts in Appendix A. The real problem here is that by the time British political leaders started to contemplate preventive action, the costs were already seen as too high. This was especially true when considering militarized preventive action. As a result, containment and other forms of nonmilitarized preventive action were preferred. This is as expected by the DPMP.

\section{8) To what extent is there the belief that the chances of winning a war now would be greater than the chances of winning a later war?}

There was the belief that there was a better chance of a favorable outcome in the short term should there be conflict, than there would be further in the future. Time did not seem to be on Britain's side. However, this was tempered by the belief that Britain could maintain its position, especially economically, if Britons simply worked harder and returned to more traditional values.

By the close of the $18^{\text {th }}$ century, war with the U.S. was seen as extremely dangerous because should such an event occur, British deployment of naval forces from Continental waters to the Western Hemisphere would leave the British home islands extremely vulnerable to invasion by Continental forces. In essence, then, war with the U.S. was simply too risky to contemplate, and a war could not be "won" either at that time or later.

As Japan rose, the danger of a Japanese-European coalition was the real danger. Once Britain had ensured that that was not going to happen, the real danger subsided. 
For British policymakers an alliance with Japan was much less risky than a war with Japan that might eventually involve other European powers.

This question is similar to the previous question. Again, the real problem is that even if a war was winnable, it was still seen as a Pyrrhic victory, especially in the wake of the Boer War. As a result, as predicted by the DPMP, non-militarized preventive action, if any action was to be taken at all, was preferred over militarized preventive action.

9) To what extent do domestic elements think the status quo will get worse for their state if the rising challenger is allowed to continue its ascendancy?

The August 1896 Board of Trade report suggested that Britain was likely to continue experiencing relative decline in the areas of manufacture and export vis-à-vis the United States and Germany. The report suggested that the only way this trend could be reversed was if a war would break out that would disrupt one or both of the competitors. Despite this gloomy outlook, there was no call for preventive action.

Regarding the free trade versus fair trade debate, there was no consensus that the status quo would continue to get worse for Britain. There was also the belief that even if Britain continued to decline relatively, it was experiencing absolute improvement. Nonetheless, prominent political leaders such as Balfour were concerned about the future relative decline of Britain. Other public officials such as Marshall, however, believed that free trade with the U.S. and Germany would stave off future relative decline for Britain.

In terms of military challenges, Germany was seen as the primary threat in terms of naval power. It was feared that the longer German naval power went unchecked, the 
worse the future would be for Britain. As has been shown, British naval planners also feared a Russian-French-German alliance. These possibilities by themselves suggested a worsening status quo.

Elsewhere in the world, it was clear that American naval power would continue to grow. The status quo for Britain in the Western Hemisphere would continue to worsen regardless of what Britain did. Any war with the U.S., the conventional wisdom ran, would only hasten the decline of British power in this part of the world. In essence, then, the rise of American naval power was seen as inevitable by most British policymakers.

British policymakers were also cognizant that Japan's naval strength was growing. After Japan defeated the Chinese and then the Russians, it was clear that the status quo in the Far East was shifting. British political leaders seemed to be aware that British power in the region was in decline relative to that of Japan, but the BritishJapanese alliance seemed to assuage the larger fears of these policymakers.

British policymakers and public officials almost universally came to see the status quo as worsening for the British people. However, many believed that with hard work and a return to traditional British values, the decline could be halted and even reversed. Then there were those who saw relative decline as inevitable as other countries grew and industrialized. British decision makers were also constrained in what they could do about the situation, even if they did acknowledge a worsening status quo. Therefore, while the answer to the question is "Yes, most British policymaker believed the status quo was worsening," there was relatively little 
preventive action taken to stop it. This represents a failure of the DPMP, which predicts that under such conditions, some sort of preventive action becomes likely.

\section{0) What is the nature (polarity) of the international system?}

John Mearsheimer suggests that the period 1816-1902 was characterized by balanced multipolarity, while the period 1903-1918 was characterized by unbalanced multipolarity. According to his theory of offensive realism, war was therefore somewhat likely from 1816 to 1902 and most likely during the period 1903-1918. ${ }^{106}$ One question this theory does not answer is this: Why did war occur in 1914 and not, in say 1910 when the structure was the same? Mearsheimer's model comes up short in answering this puzzle.

The typology of preventive action developed in this study also incorporates Mearsheimer's concepts of polarity. Within the typology, a "Balanced multipolar" system suggests that Britain should have acquiesced, which is largely correct. However, in the later "unbalanced multipolar" system, the typology predicts that Britain should have used coercive/confrontational diplomacy. On this point, the typology does not do a good job of accurately predicting the outcome.

\section{1) What type of government exists in each state, i.e., are either or both} democracies? ${ }^{107}$

Between 1816 and 1879, the United Kingdom was an anocracy. During this period, Prussia/Germany and Russia are classified as autocracies and Japan as an

\footnotetext{
${ }^{106}$ See John J. Mearsheimer, The Tragedy of Great Power Politics (New York: W. W. Norton \& Company, 2001).

${ }^{107}$ See Ibid. See also Randall L. Schweller, "Domestic Structure and Preventive War: Are Democracies More Pacific?," World Politics 44, no. 2 (1992).
} 
anocracy. The United States was a full democracy during this period. Therefore, according to Schweller's model, the United Kingdom should have either formed a defensive alliance or initiated preventive war against Germany/Prussia, Japan, Russia, and the U.S. ${ }^{108}$ Of course, what we have seen is that Britain was moving toward a defensive alliance with Japan and acquiesced to American demands in the Western Hemisphere. Schweller's model does not provide an adequate explanation for this.

From 1880 to 1896, the UK was a full democracy. Germany and Russia were autocracies, Japan is classified as an anocracy, and the U.S. was a full democracy. Therefore, the UK should have formed a defensive alliance against Germany, Russia, and Japan and should have accommodated the rise of the United States. While the UK did accommodate the rise of the U.S., it did not form a defensive alliance against Japan, but instead moved still closer to accommodation with Japan.

From 1897 to 1902, the UK was a full democracy. Germany and Russia, on the other hand, were autocracies during this period and Japan is classified as an anocracy. ${ }^{109}$ Therefore, the UK should have formed a defensive alliance against Germany, Russia, and Japan. In 1902, Britain and Japan formally signed a defensive alliance. This is not explained by Schweller's model.

During 1903 and 1904, the United Kingdom was a full democracy. Germany and Japan were anocracies and Russia was an autocracy during this period. Schweller's model predicts that the United Kingdom should have sought a defensive alliance against Germany, Russia, and Japan during this period. Instead, Britain and Japan

\footnotetext{
${ }^{108}$ All statements about the level of democracy are based on the Polity IV rating. If a state is rated 7 to 10 , then I consider it a full democracy. If it is rated a 1 to 6 it is an anocracy, and I treat it as a non-democracy. States receiving a zero or negative rating are considered autocracies by Polity IV. See Appendix C for selected Polity IV scores. 109 Japan was undergoing an "adverse transition" from 1860 to 1867 , and then it was an anocracy.
} 
were allied. Germany and Russia, however, were still seen as adversaries by British political leaders.

Between 1905 and 1913, the United Kingdom was a full democracy. Japan, on the other hand, was an anocracy during this period. Therefore, according to Schweller, the United Kingdom should have sought a defensive alliance against Japan during this period. Finally, from 1914 to 1918, the United Kingdom was a full democracy while Russia and Japan were anocracies. Therefore, according to Schweller, the United Kingdom should have sought a defensive alliance against Russia and Japan during this period. Of course, as has been seen above, this did not occur. Nonetheless, Schweller's model does work well for all of these periods if we consider the fact that Japan was an anocracy during all of these periods and not an outright autocracy. It does not, however, explain why Britain was willing to enter into a defensive alliance with Japan but not with the anocratic Germany (after 1903). Still, it is impossible to discount his model completely. All of these periods and predictions are summarized in table 4.2. 
Table 4.2 Mearsheimer's and Schweller's Predicted Outcomes

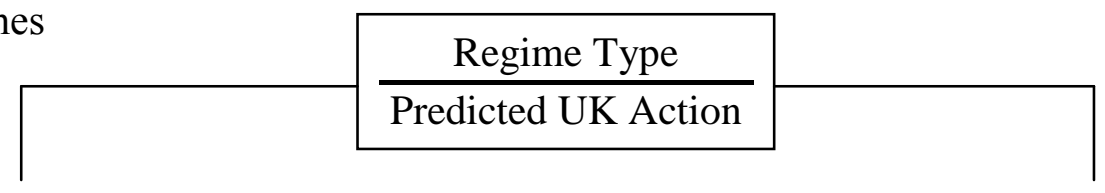

\begin{tabular}{|c|c|c|c|c|c|c|}
\hline \multirow[t]{2}{*}{ Time Period } & Power Distribution & \multirow[b]{2}{*}{$\mathbf{U K}$} & \multirow[b]{2}{*}{ Prussia/Germany } & \multirow[b]{2}{*}{ Russia } & \multirow[b]{2}{*}{ Japan } & \multirow[b]{2}{*}{ US } \\
\hline & Predicted Outcome & & & & & \\
\hline \multirow[t]{2}{*}{$1816-1879$} & Balanced Multipolar & \multirow[b]{2}{*}{ Anocracy } & Autocracy & Autocracy & Anocracy & Democracy \\
\hline & War Somewhat Likely & & $\begin{array}{l}\text { Defensive Alliance } \\
\text { or Preventive War }\end{array}$ & $\begin{array}{l}\text { Defensive Alliance } \\
\text { or Preventive War }\end{array}$ & $\begin{array}{l}\text { Defensive Alliance or } \\
\text { Preventive War }\end{array}$ & $\begin{array}{l}\text { Defensive Alliance or } \\
\text { Preventive War }\end{array}$ \\
\hline \multirow[t]{2}{*}{$1880-1896$} & Balanced Multipolar & \multirow[t]{2}{*}{ Democracy } & Autocracy & Autocracy & Anocracy & Democracy \\
\hline & War Somewhat Likely* & & Defensive Alliance & Defensive Alliance & Defensive Alliance & Accommodation \\
\hline \multirow[t]{2}{*}{$1897-1902$} & Balanced Multipolar & \multirow[t]{2}{*}{ Democracy } & Autocracy & Autocracy & Anocracy & \\
\hline & War Somewhat Likely & & Defensive Alliance & Defensive Alliance & Defensive Alliance & \\
\hline \multirow[t]{2}{*}{ 1903-1904 } & Unbalanced Multipolar & \multirow[t]{2}{*}{ Democracy } & Anocracy & Autocracy & Anocracy & \\
\hline & War most likely & & Defensive Alliance & Defensive Alliance & Defensive Alliance & \\
\hline \multirow[t]{2}{*}{$1905-1913$} & Unbalanced Multipolar & \multirow[t]{2}{*}{ Democracy } & & & Anocracy & \\
\hline & War most likely & & & & Defensive Alliance & \\
\hline \multirow[t]{2}{*}{ 1914-1918 } & Unbalanced Multipolar & \multirow[t]{2}{*}{ Democracy } & & Anocracy & Anocracy & \\
\hline & War most likely & & & Defensive Alliance & Defensive Alliance & \\
\hline
\end{tabular}

Blank boxes indicate that the United Kingdom was no longer in relative decline vis-à-vis the other power or the other power had surpassed the UK. Either condition is outside the scope of this research. 


\section{Conclusion}

The most striking aspect of British foreign policy vis-à-vis rising states from 1816 to the second decade of the twentieth century is its acquiescence and accommodation. In essence, it allowed the United States, Germany, Japan, and Russia to rise relative to it, and in some cases to surpass it, with little or no effort to check their ascendance. The periphery was increasingly left to powerful, but for the moment at least, friendly nations. Whether the threat was economic or financial, as in the case of the United States and Germany, or primarily military - as in the case of Russia, Japan, and Germany - the United Kingdom did little to stop the rise of the threatening power. British public officials thus came to accept a geographically constrained form of naval superiority in which England could maintain its two-power standard only in European waters. This strategy implied coming to some accommodation with the peripheral powers and perhaps, as the European states increased their naval strength, with one or more of them as well.

The typology and models developed for this research project perform about as well as Mearsheimer's polarity model and Schweller's democracy model. Despite the preventive action typology's failures, it still has some value in trying to predict, with more precision, the actions of Britain during this time. On some dimensions such as internal power constraints and ruler belief systems, the DPMP performed very well in this case study. On other dimensions such as system polarity and perceived likelihood of conflict, the model failed to predict accurately British behavior. This suggests that while the DPMP is far from perfect, with some modifications it may become a valuable tool in predicting the likelihood of different forms of preventive action. 


\section{Chapter Five \\ The Decline of Russia and the Soviet Union}

\section{$\underline{\text { A Brief History to } 1816}$}

This chapter examines the decline of Russia and the Soviet Union vis-à-vis several rising powers from 1816 to the mid 1940s. It is helpful, however, to outline a brief history of the emergence and rise to power of this pivotal nation. This section is meant to serve only as a very brief overview of the rise of Russia and the Soviet Union. In this project, of course, we are much more interested in its decline, the rise of challengers, and its reaction to those events.

The rise of Russia really begins with Peter the Great's conquests of the early eighteenth century. ${ }^{1}$ Russia emerged on the international scene with its growth of military power and its defeat of the Swedes at Poltava in July 1709. Aided by numerous foreign advisers and willing to borrow widely from the military expertise of the West, Peter the Great built up a massive army and navy to protect his new possessions on the Baltic. Later in the eighteenth century, Russia's army was often larger than that of France. Russia's manufacturing base was also gaining strength and the country itself was difficult if not impossible to conquer, as Napoleon (and later Hitler) was to discover. Though it was still a backward country in many ways, it showed signs of modernizing on several fronts. By borrowing from other countries and thanks to its vast resources, it was able to catch up and then surpass other states. ${ }^{2}$

By the time of the Seven Years' War (1756-1763), Russia could be considered a great power. The country's armies fought courageously and occupied Berlin in $1760 .{ }^{3}$ Russia retired

\footnotetext{
${ }^{1}$ David L. Ransel, "Pre-Reform Russia 1801-1855," in Russia: A History, ed. Gregory L. Freeze (New York: Oxford University Press, 2002), 148.

${ }^{2}$ Paul Kennedy, The Rise and Fall of the Great Powers: Economic Change and Military Conflict from 1500 to 2000 (New York: Vintage Books, 1987), 107.

${ }^{3}$ Ibid., 94-95.
} 
into profitable neutrality before the war ended, and at the end of the conflict, Russia emerged secure and dominant in the east and north. ${ }^{4}$

By the end of the eighteenth century, Russia was among the most powerful nations in the world. By 1792, for example, Russia had made great advances at Turkey's expense. It had annexed the Crimea and it had secured the northern coast of the Black Sea. Furthermore, by 1796 Catherine the Great had added 200,000 square miles to the already huge Russian Empire. Russia's raw numbers in terms of population also allowed it to occasionally field an effective offensive military force. ${ }^{5}$ With the Russian defeat of Napoleonic France, Alexander was ready to lead Russia into the top tier of European powers. ${ }^{6}$

\section{Power Relations $^{7}$}

\section{$\underline{\text { Russia/Soviet Union vis-à-vis the United States }}$}

For most of the years between 1816 and 1860, Russia was dominant but in relative decline vis-à-vis the United States. In 1861, the United States' CINC score surpassed that of Russia and the U.S. maintained its dominance with only short periodic breaks until the early 1970s when Russia once again dominated the U.S. This condition lasted until just before the end of the Soviet Union in the late 1980s and early 1990s. See figure 5.1 below.

\footnotetext{
${ }^{4}$ Paul W. Schroeder, The Transformation of European Politics 1763 - 1848, ed. Lord Bullock and William Deakin, Oxford History of Modern Europe (New York: Oxford University Press, Inc., 1994), 3.

${ }^{5}$ Kennedy, The Rise and Fall of the Great Powers: Economic Change and Military Conflict from 1500 to 2000, $94-$ 119.

${ }^{6}$ Ransel, "Pre-Reform Russia 1801-1855," 152.

${ }^{7}$ As mentioned in chapter three, in order to assess power shifts after 1816, I use the Composite Index of National Capability (CINC) score derived from the National Material Capabilities (v3.02) index. This is part of the Correlates of War (COW) project and can be accessed at http://www.correlatesofwar.org/.
} 


\section{Figure 5.1}

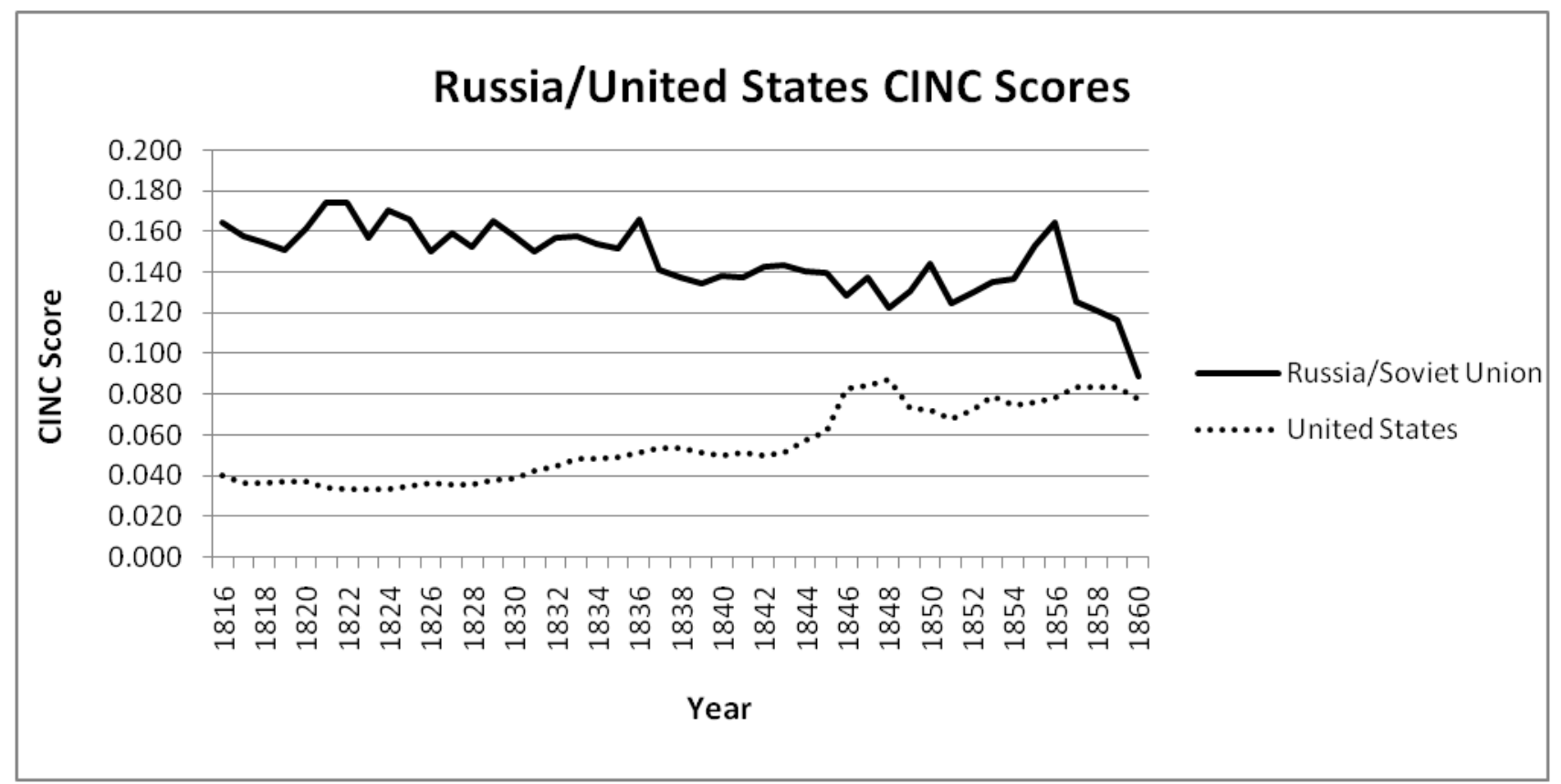

\section{$\underline{\text { Russia/Soviet Union vis-à-vis Prussia/Germany }}$}

Closer to the Fatherland, Prussia/Germany posed a more immediate threat than the United States for much of this period. Between 1816 and 1878, Russia dominated Prussia/Germany, but Russia was in relative decline nearly the whole time. Germany dominated the bilateral relationship between 1879 and the end of the First World War. The 1920s once again brought Russia into the dominant position, but the first half of that decade presented a slowly declining Russia, and in 1923, 1924, and 1927 Russia declined more conspicuously relative to Germany. By the 1930s, Russia was in steady relative decline and was overtaken by Germany starting in 1939 and lasting until the end of the Second World War. Germany, of course, was divided after the end of World War II, and did not emerge again as a united political entity until 1990, at which time Russia dominated the newly united country. However, throughout the 1990s Russia was in relative decline vis-à-vis Germany. See figure 5.2 below. 
Figure 5.2

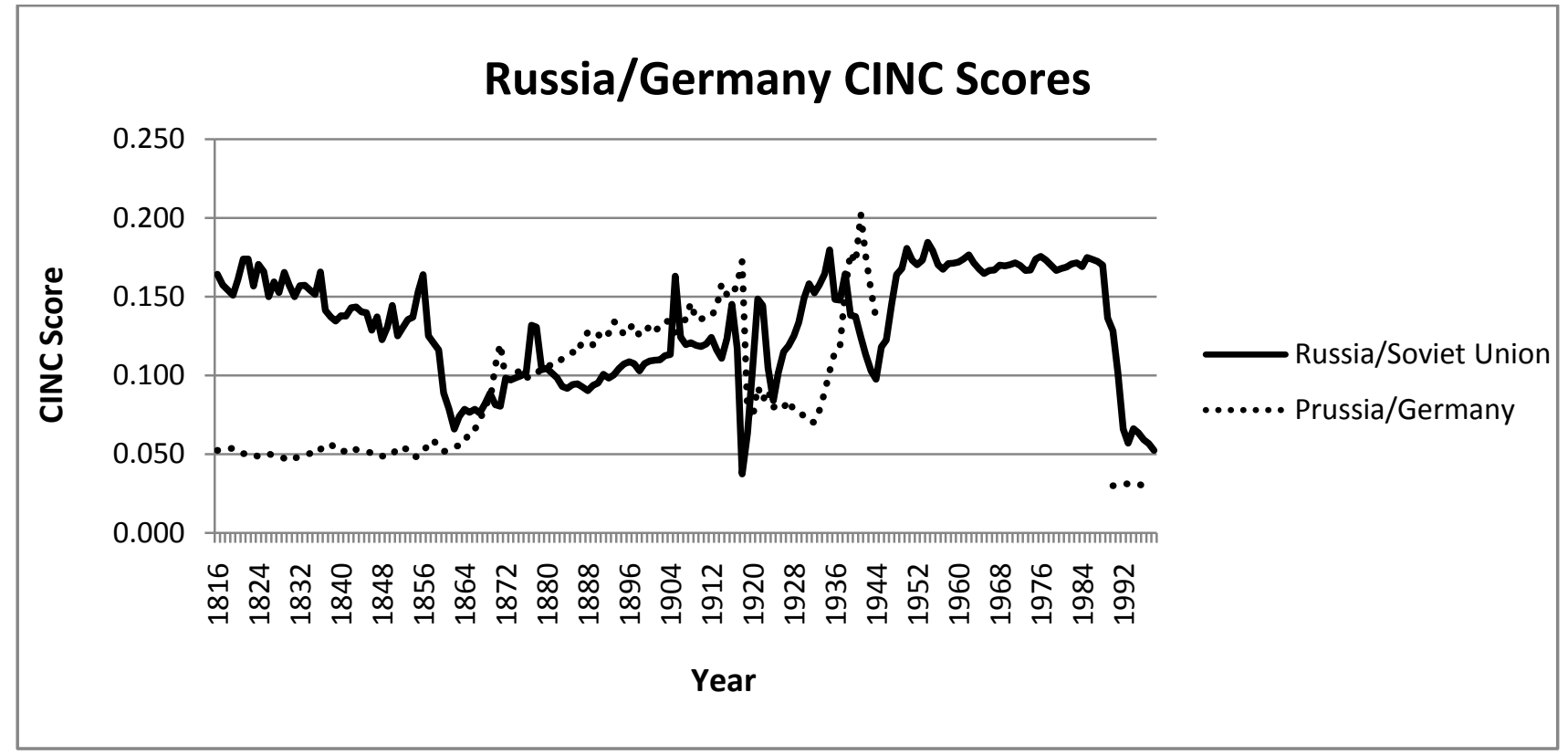

$\underline{\text { Russia/Soviet Union vis-à-vis Japan }}$

Russia’s power relationship with Japan has been complex. Russia dominated Japan from 1860 (the first year of data available for Japan) until 200 when Japan reached parity with Russia. Most of the fluctuations in relative power during the entire period 1860-1995 have more to do with the ups-and-downs of Russian/Soviet power than they do with an increase or decrease in Japanese power. However, the two periods, 1894-1945 and 1952-1973 were generally positive times for Japan in terms of power. See figure 5.3 below. 


\section{Figure 5.3}

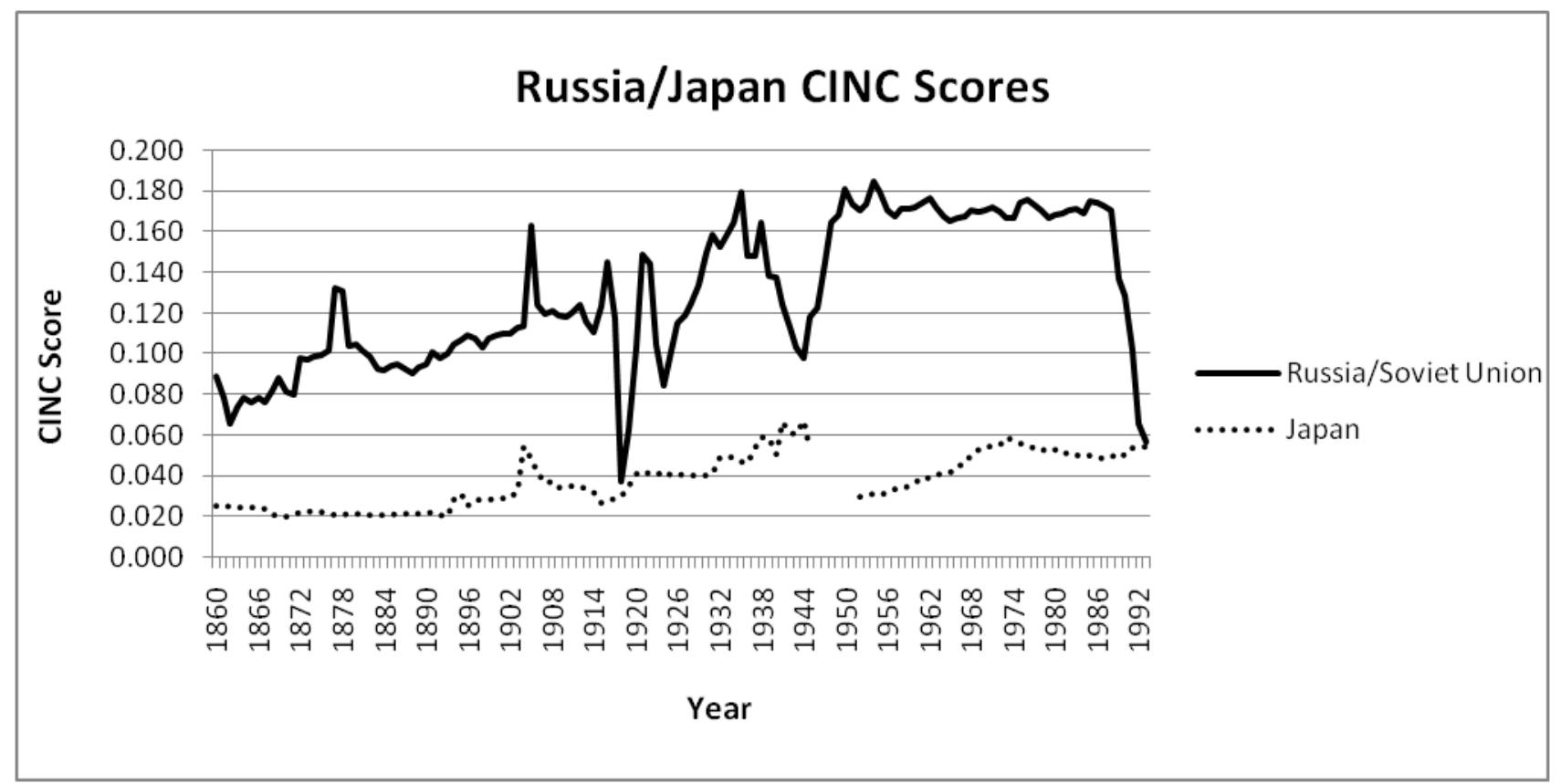

$\underline{\text { Russia/Soviet Union vis-à-vis the United Kingdom }}$

Britain lost its consistently dominant status vis-à-vis Russia shortly after the turn of the twentieth century. After 1905, Russia and then the Soviet Union was more often than not in a dominant position over Britain. By the 1920s, the Soviet Union was clearly dominant over the United Kingdom, and it never relinquished that dominance. Russia has maintained its dominance over Britain in the post Cold War period. Though the Soviet Union was dominant in the period 1936-1946, it was in relative decline vis-à-vis the U.K. during most of that time. The period 1972-1979 was another period of relative decline for the Soviet Union. 1984 to 1998 is the final period covered in this study in which the Soviet Union/Russia was dominant but in relative decline vis-à-vis the United Kingdom. See Figure 5.4 below. 


\section{Figure 5.4}

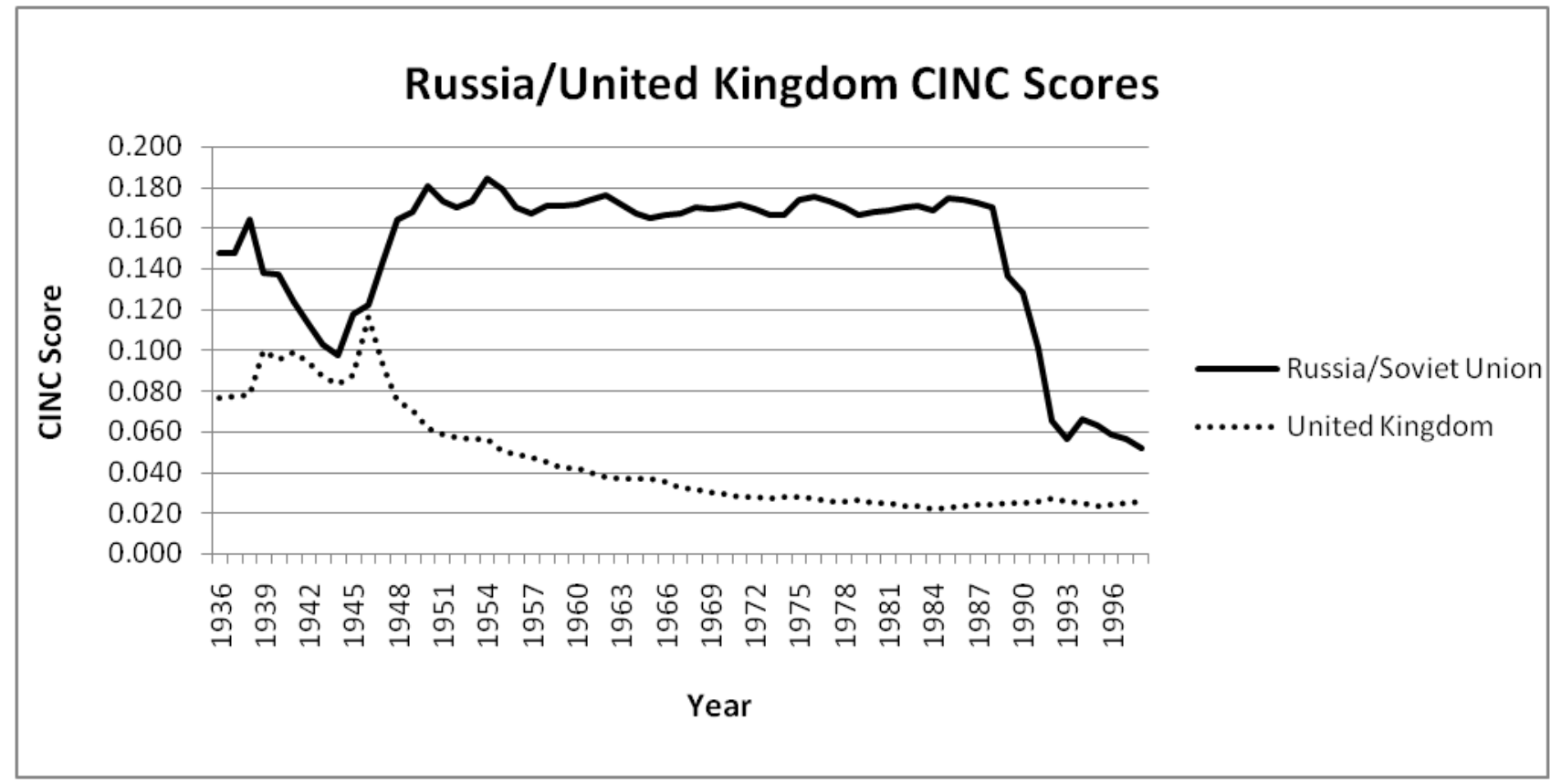

This chapter examines the following instances in which Russia/the Soviet Union was in a dominant but relatively declining position in relation to the challenger ${ }^{8}$ :

Russia/United States: 1816-18609

Russia/Germany: 1816-1878, 1932-1938, 1990-1998 ${ }^{10}$

Russia/Japan: 1860-1873, 1878-1888, 1892-1906, 1913-1918, 1936-1944, 1951-1967, 1977 $1979,1986-1993^{11}$

Russia/United Kingdom: 1936-1946, 1972-1979, 1984-1998 ${ }^{12}$

\footnotetext{
${ }^{8}$ For purposes of clarity, I may refer to the Soviet Union as simply Russia at certain points of this chapter.

${ }^{9}$ Obviously, the conditions did not exist during the Cold War for the Soviet Union to engage in preventive action against the United States since it was not in a dominant position over the U.S. I will, however, examine the possibility of preventive action on the part of the U.S. during this period in the next chapter.

${ }^{10}$ I will not be looking at Russian-German relations from 1990-1998. While it is true that Russia was in a dominant position vis-à-vis Germany during this period, and while it is true that Russia was in relative decline during this period (the two main criteria I require for my cases to be included in this study) the international system coming out of the Cold War simply would not have allowed the failing Soviet Union or the new Russia from engaging in preventive action against Germany. Germany, as part of NATO, still fell under the protection of that alliance; and it is difficult to see how Russia would contemplate preventive action, especially of a military nature, against Germany. Internally, Russia was preoccupied with holding together whatever parts of the former Soviet Union it could. Preventive action, therefore, during this period was simply not a viable option.

${ }^{11}$ Much like the German case, preventive action against Japan after World War II was not a real possibility due to the U.S.-Japanese alliance and later the internal problems of the Soviet Union/Russia.
} 
To simplify matters somewhat, the following time periods encapsulate the above scheme: 1816$1888,1892-1906,1913-1918,1932-1946$

\section{Nature of the Threat}

\section{Economic Challenges}

Russia's finances suffered heavily from the series of wars that occurred during the late eighteenth and early nineteenth centuries. The government printed paper money at a fantastic rate, increasing the number of rubles in circulation from 200,000,000 in 1801 to nearly $826,000,000$ in 1816 . As the number of rubles in circulation increased, their value decreased to the point that by 1816 , the value of the paper ruble was only a quarter of a silver ruble ( 25 silver kopeks). ${ }^{13}$ Despite attempts by Finance Ministers Count D. A. Guryev and Egor Kankrin, who had succeeded in bringing inflation under control and had laid a solid foundation for economic growth, the expensive and ultimately futile war in the Crimea had wreaked havoc on state finances. $^{14}$

The area of trade relations presented further challenges for the Russian state. Russia, like the rest of Europe, gravitated from free trade to protectionism in the second half of the $19^{\text {th }}$ century. Tariffs rose from their lows of the late 1850s and early 1860s—first to a 10 percent tariff in 1881, then 20 percent in 1885 , and finally to a prohibitive tariff of 33 percent in $1891 .^{15}$ Ministers of Finance Ivan Vyshnegradskii (1887-92) and Sergei Witte (1892-1903) imposed high

\footnotetext{
${ }^{12}$ Like Germany and Japan, the United Kingdom also fell under the protective umbrella of the United States in the post World War II era. Preventive action, especially of a military nature, was simply not a viable possibility for the Soviets.

${ }^{13}$ Hugh Seton-Watson, The Russian Empire 1801-1917, ed. Alan Bullock and F. W. D. Deakin, Oxford History of Modern Europe (Oxford: The Clarendon Press, 1967), 157.

${ }_{15}^{14}$ Ransel, "Pre-Reform Russia 1801-1855," 160-66.

${ }^{15}$ Gregory L. Freeze, "Reform and Counter Reform 1855-1890," in Russia: A History, ed. Gregory L. Freeze (New York: Oxford University Press, 2002), 185.
} 
protective tariffs that were designed to improve Russia's balance of trade and promote domestic industries.

Witte's domestic program was cautious and conservative. It postponed immediate gratification and saw economic development as the key to future increases of power. Witte's initial successes in the 1890s led to a rate of industrial growth for Russia never to recur until the 1930s. ${ }^{16}$ Industrial production increased at an average of 8 percent per year, higher even than that of the United States. As Reginald Zelnik notes, “Russia's presumptive but precarious position as a 'great power' provided an underlying motivation for the pursuit of economic development, industrial strength, and financial independence." ${ }^{\prime 17}$ Unfortunately, Witte's policies became increasingly difficult to maintain as Russia became ensnared in Asian affairs. Tariffs implemented during this time were not designed to stunt the growth of potential challengers, at least not overtly, but they were created to help Russia maintain its great power status. Prestige was continuing to be an important factor for the Russians.

By the early 1920s, years of warfare had once again ruined the national economy. In 1921, for example, the country was facing total economic collapse. In that year, gross industrial output fell to less than one-fifth of the level before World War I, and production in the textiles industry was a mere one-tenth. Similarly, agricultural production was severely reduced during this period. Famine and epidemics claiming millions of lives ensued when the 1921 harvest produced significantly less than half the pre-war average. By 1922, hyperinflation was once again rampant and had driven prices for agricultural products to astronomical heights. The Soviet

\footnotetext{
${ }^{16}$ Reginald E. Zelnik, "Revolutionary Russia 1890-1914," in Russia: A History, ed. Gregory L. Freeze (New York: Oxford University Press, 2002), 209.

${ }^{17}$ Ibid., 203-09.
} 
government responded with a tight-money policy that caused difficulties in wage payments at many factories thereby triggering strikes and disorders. ${ }^{18}$

Economics, not ideology, drove the Soviets to engage in economic agreements with the West in the aftermath of World War I. For example, the Russians signed a trade agreement with the British in March 1921. Germany and the Soviet Union also signed the German-Russian Agreement of 19 April 1922. One of the goals of the Treaty of Rapallo was to form closer economic ties between Germany and Russia. ${ }^{19}$ Clearly, economic necessity trumped ideological orthodoxy during this period.

Vladimir Lenin, recognizing the weakness of the Soviet economy, argued that military conflict between the capitalist and socialist camps was not necessarily inevitable. He suggested that they could both compete and cooperate with each other. According to his line of logic, socialist states could interact, especially economically, with the capitalist world because in any long-term competition socialism would ultimately prevail. This was a very pragmatic ideological shift given that the international proletarian revolution that was supposed to have occurred did not emerge, and therefore the Western assistance that was to have flowed to the new Soviet state did not materialize. Lenin and other Soviet leaders recognized that it was vital that the USSR end its diplomatic isolation and attract financial aid. This proved to be quite difficult, and as the decade opened not a single major industrial nation had yet given the revolutionaries diplomatic recognition. Nor were there any signs of significant foreign investment in the new state. ${ }^{20}$

Despite these setbacks, by 1924 the national economy began to recover. Restarting factories closed during the civil war caused a sharp rise in manufacturing output. As a result, the

\footnotetext{
${ }^{18}$ William B. Husband, "The New Economic Policy (Nep) and the Revolutionary Experiment 1921-1929," in Russia: A History, ed. Gregory L. Freeze (New York: Oxford University Press, 2002), 264-75.

${ }^{19}$ Ibid., 273-74.

${ }^{20}$ Ibid., 273.
} 
output of large-scale industry reached nearly half its pre-war scale in 1924 and 75 per cent a year later. Industrial exports rose to nine times what they had been at the beginning of the decade, even if still only a third of pre-war figures. By 1924, the cultivation of arable land approached 1913 levels, and marketable output in agriculture increased 64 percent between 1922 and $1925 .^{21}$

This, of course, was only a recovery of the pre-war base, not an expansion. Industry soon reached a point of diminishing returns. There had been virtually no investment in industrial capacity since before the First World War. What the Russian civil war had not destroyed was, by the mid-1920s, badly worn or outmoded. Restarts of old factories could increase output, but without significant new investment, these factories could never reach the pre-war standard. Meanwhile, trade and foreign investment, which increased significantly after 1921, still fell far short of financing a renewed industrial base. ${ }^{22}$

The Communists' answer to these shortcomings was the announcement of the 'Five-Year Plan for Industrialization and Socialist Construction'. Henceforth, the state would not only intervene in economic relations but would actually serve as the chief, even sole, manager of the economy. This ambitious plan aimed to dramatically increase investment, industrial production, electrical generation, and the size of the industrial labor force. Even with these grand goals, Stalin was unsatisfied and by the end of 1929 'Five in Four' - that is, the fulfillment of the Plan in four years - became official policy. The result of the increased expectations was a constant state of emergency, ubiquitous shortage, and near total chaos of the Soviet economy that sometimes spilled over into the larger Soviet society itself. ${ }^{23}$

\footnotetext{
${ }^{21}$ Ibid., 276.

${ }^{22}$ Ibid.

${ }^{23}$ Lewis Siegelbaum, "Building Stalinism 1929-1941," in Russia: A History, ed. Gregory L. Freeze (New York: Oxford University Press, 2002), 295-97.
} 
The Five Year Plan's record was mixed, but by 1932 Stalin could claim some real achievements. Gross industrial production and producers' goods surpassed the ambitious goals laid out in the Five Year Plan. During this period, the value of machinery more than quadrupled. Total employment in construction, transportation, and industry also exceeded the benchmarks set by the Plan. On the other hand, the production of consumer goods was less impressive, and there were significant shortfalls in the output of coal, electricity, and steel. ${ }^{24}$

Stalin recognized the shortcomings in the Soviet economy and remarked to a conference of economic officials during the First Five-Year Plan, "Do you want our socialist fatherland to be beaten and to lose its independence?" He further stated, "We are fifty or a hundred years behind the advanced countries. We must make good this distance in ten years. Either we do it, or we shall go under." The Soviet government thus set out to quickly industrialize the country. It was largely because of this forced-pace industrialization that the Soviets were victorious in the Great Patriotic War of 1941-1945. However, because of increased military expenditure, investment in the collective and state farm system remained woefully inadequate. Agriculture still lagged and a major crop failure in 1936 strained the state's reserves and distribution network. ${ }^{25}$

After the Second World War, the Fourth Five-Year Plan, which was adopted in March 1946, set the target of exceeding pre-war levels of production by the end of 1950. In fact, the Soviet Union fulfilled this plan in most significant sectors. By 1950, for example, gross industrial output exceeded that of 1940 by 40 percent. $^{26}$

\footnotetext{
${ }^{24}$ Ibid., 297.

${ }^{25}$ Ibid., 317-18.

${ }^{26}$ William C. Fuller, Jr., "The Great Fatherland War and Late Stalinism 1941-1953," in Russia: A History, ed. Gregory L. Freeze (New York: Oxford University Press, 2002), 336.
} 


\section{Military Threats}

The years from 1815 to 1914 marked a time of relative peace in Europe. During this period, there were no general wars between the great powers. The five Great Powers that had organized the Congress of Vienna continued to dominate Europe. The wars that did break out were short and limited in scope. ${ }^{27}$ For the forty years after Russia defeated Napoleon, Europeans regarded Russia as the most formidable power on the continent. However, Russia failed to progress at the same rate as competing nations in the areas of weapons development, logistical support, education, and industry. Russia, for example, was very late in developing a railroad system. This ultimately hindered its ability to supply troops in the Crimea. The sorry state of their military can be seen in the defeats they suffered at the hands of the Japanese (1904-1905), the Germans (1914-1918), and the Poles (1920). ${ }^{28}$

Russian foreign policy in the nineteenth century was a complex picture that promised further Russian advances. By 1814, Russia was the greatest continental power and took an interest in all European problems. Alexander I, who reigned as emperor from 1801 to 1825 , expected that Russia would play a leading part in all Continental affairs. He was in favor of establishing a new system of international order and peaceful cooperation with the other Continental powers. As a consequence of this newfound activism, Russia was involved in the settlement at the Congress of Vienna. ${ }^{29}$

Alexander I also worked outside the bounds of the Congress of Vienna to enhance Russia's involvement with the rest of the Continent. In September 1815, he drafted the Holy Alliance in which he, the Emperor of Austria, and the King of Prussia were 'to take for their sole

\footnotetext{
${ }^{27}$ Norman Davies, Europe: A History (New York: Harper Perennial, 1996), 866-67.

${ }^{28}$ Ransel, "Pre-Reform Russia 1801-1855," 167-68.

${ }^{29}$ Seton-Watson, The Russian Empire 1801-1917, 149-74.
} 
guide the precepts of the Christian religion'. The alliance became a symbol of the association of the three eastern monarchies. ${ }^{30}$

Similarly, the Quadruple Alliance of Russia, Prussia, Austria, and Britain, which had come into effect in 1814, opened the door for periodic meetings between the rulers of the four powers and their foreign ministers. ${ }^{31}$ The first of these meetings was held at Aachen from September to November 1818. Its main business was to arrange for the evacuation from France of the allied armies of occupation. ${ }^{32}$

By the time of the outbreak of war over the Crimea, Nicholas' army looked strong on paper but it was no match for the allies. Russia's army was widely disbursed to protect against possible border attacks. The lack of industrialization and the lack of railroads proved to be a serious detriment to the forces sent to the Crimea. These forces actually had to be supplied by ox cart. Russian weapons, which had not been upgraded since earlier wars, had far shorter effective range than the enemy's weapons. To make matters worse, sanitary conditions for Russian troops were appalling, and disease claimed far more men than did battle. Not surprisingly, the troops were demoralized and ultimately defeated. At the same time, Nicholas became ill and died of pneumonia in early February $1855 .^{33}$

By 1856, in the wake of the war in the Crimea, Russia underwent numerous internal reforms including the gradual elimination of serfdom, education reform, judicial reform, and finally reform of the military. The Russian military adopted Western models and improved military technology, reorganized military administration, and improved the professionalism of military schools. The Universal Military Training Act of 1874 established universal conscription

\footnotetext{
${ }^{30}$ Ibid., 175.

${ }^{31}$ Davies, Europe: A History, 762-63.

32 Seton-Watson, The Russian Empire 1801-1917, 175.

${ }^{33}$ Ransel, "Pre-Reform Russia 1801-1855," 167.
} 
regardless of class standing, a significant change over the old system in which the nobility was exempt from military service. Under the 1874 Act, terms of service were determined by level of education, not by social origin or rank. ${ }^{34}$

Forces drawing the Western Powers to Russia were also in play in the later $19^{\text {th }}$ century. When, in 1875, Bismarck threatened France with preventive war if it attempted to rearm, Russia and England saw this as overtly threatening and believed that the Germans were trying to start a war. In St. Petersburg and London, France found far more sympathy than Bismarck had expected. He had tried to turn European powers against France by presenting her as a state bent on domination through rearmament, but instead found that he was himself viewed as the rogue. This view was led by England and Russia, the two countries who were supposedly Germany's closest friends. Instead of criticizing France's rearmament or joining Germany's preventive war to stop the rearmament, Russia and England endorsed France's "very natural" rearmament program while denying the legitimacy of preventive war. ${ }^{35}$

Threats by Germany were not the only incentives driving the West into closer relations with Russia. In a poor state like Russia, which taxed its poorest citizens harshly, social and political revolution was seen as a real possibility. In reaction to this, and in the face of a rising Germany, the Western Powers worked to enhance their political ties with Russia. From 1890 to the outbreak of the First World War, France, Britain, and Belgium invested heavily in the giant to the east. Because of these investments, Russia's railways, industry, and foreign trade all increased dramatically. ${ }^{36}$

\footnotetext{
${ }^{34}$ Freeze, "Reform and Counter Reform 1855-1890," 170-80.

${ }^{35}$ Alfred Vagts, Defense and Diplomacy: The Soldier and the Conduct of Foreign Relations (New York: King's Crown Press, 1956), 287-90.

${ }^{36}$ Davies, Europe: A History, 765-66.
} 
Russia's power was also enhanced by an increasing population that nearly doubled between 1863 and 1913. However, the country was economically backward when compared with its European counterparts. For example, the only rail line in Russia in 1855 ran between Moscow and St. Petersburg. As a result, it was difficult to move key resources around the country and key markets remained isolated. Russia still imported 70 percent of all machinery and did not have upto-date technology. All of this began to change in the final years of the 1870 s, and by the mid 1880s railway lines had increased from 1484 miles in 1861 to 18,720 miles in 1887. At the same time, the industrial base grew substantially and industrial production roughly doubled during the period $1861-1886 .^{37}$

Between the 1830s and the 1870s, Russia consolidated its power in the territories that bordered it. Poland was systematically dismantled as an independent state with the abolition of the Polish governmental councils in 1867 , the reorganization of the area into ten Russian administrative provinces in 1868 , the conversion of Warsaw University into a Russian institution in 1869 , and the introduction of the Russian judicial system in 1876. Russia also used force in the Caucuses to put down a resistance movement there. The military campaign of 1857-62 achieved a semblance of control, but Russian power remained tentative and vulnerable. The 1860s and 1870s also marked the expansion of Russian rule into Central Asia. The motives for such a move came from two sources: an interest in its capacity for cotton production, and a desire to establish a firm and reliable border in the area. As a result, between 1864 and 1873 Russia gradually reduced Central Asia to a protectorate status with unmistakable Russian

\footnotetext{
${ }^{37}$ Freeze, "Reform and Counter Reform 1855-1890," 182-84.
} 
predominance. ${ }^{38}$ In the years just before 1914, the Russian Empire was advancing rapidly towards modernity. ${ }^{39}$

Late Imperial Russia seemed to contain within its borders inexhaustible stores of power and energy. It was the largest consolidated state in the world, it had the largest population in Europe, and it had the world's largest army. It produced more agricultural products than any other state in Europe and was the chief recipient of external investment thanks to its massive mineral resources. ${ }^{40}$

The leaders of Russia during this time wanted to prolong the European peace to provide continued stability in which Russia could continue its development. Russia was a leading proponent of peace conferences in the late $19^{\text {th }}$ and early $20^{\text {th }}$ centuries. Peace conferences at The Hague in 1899 and 1907 were largely held at the Tsar's urging. Disarmament, the arbitration of international disputes, and the rules of land warfare were the topics of discussion at these conferences. Out of these meetings emerged the International Court of Justice in 1900 and the Hague Convention in $1907 .^{41}$ Alas, peace was not meant to last indefinitely. The outbreak of the First World War and then internal revolution would immerse Russia into turbulence for years.

As the world slipped toward the First World War, alliances began to play a key role in European politics. The agreements between Russia and France obliged them to assist each other if attacked, but the third member of the Triple Entente, Great Britain, was not formally committed to come to their defense. In addition, there was no treaty in force between Russia and Serbia. Even the treaty of 1839, which committed Britain to uphold Belgian independence, predated the Triple Entente. Despite appearances, then, these countries were not locked into

\footnotetext{
${ }^{38}$ Ibid., 191.

${ }^{39}$ Davies, Europe: A History, 765.

${ }^{40}$ Ibid., 853-54.

${ }^{41}$ Ibid., 874-75.
} 
automatic responses to aggression. They actually had quite a bit of room to maneuver. The fact is that in 1914, they all chose war.

In St. Petersburg, Tsar Nicholas II had ordered full mobilization on 30 July. It seems that he did not consult the Minister of War before making his decision. News of Germany's declaration of war, which had occurred on 1 August, quickly reached St. Petersburg and on 2 August, Russia declared war on Germany. The Russians hoped that they would be able to mobilize fully their army in eighteen days and that they would 'be in Berlin before the Germans were in Paris. $^{, 42}$

February 1917 ushered in a revolution in which the tsar agreed to abdicate his throne. Amidst the crisis of war and social upheaval, the provisional government tried to rule and reform. Poland, which was under the occupation of the Central Powers, was granted virtual independence by the provisional government. Autonomy was also granted to Finland. In the wake of the Bolshevik Revolution, the Allies tried to intervene in the emerging Soviet Union, but their intervention had little military effect. ${ }^{43}$

The new Soviet state tried to further its rise to power through the New Economic Policy (NEP) of the 1920s. It was hoped that NEP would ignite revolution in Europe thus creating Soviet friendly governments and improving the standing of the Soviet Union in Europe. None of this came to pass. While Lenin had pursued 'peaceful coexistence' with the capitalist world, Stalin emphasized what he saw as the link between foreign threats and the internal mobilization of the Soviet populace and resources. For Stalin, it looked as if the capitalist powers wished to encircle the Soviet state. Soviet behavior, based on this belief of encirclement by hostile powers bent on the destruction of the USSR, only served further to estrange the USSR from the rest of

\footnotetext{
${ }^{42}$ Ibid., 894. The quote is from a British military attaché.

${ }^{43}$ Daniel Orlovsky, "Russia in War and Revolution 1914-1921," in Russia: A History, ed. Gregory L. Freeze (Oxford: Oxford University Press, 2002), 235-56.
} 
the international system. As a result of this behavior, the Soviet Union was widely distrusted by the end of the 1920s, and it did not have any reliable allies. The situation for the Soviet Union at the end of the decade was little better than it had been at the beginning of the decade. ${ }^{44}$

Despite its militaristic overtones, the Soviet government realized during the period of the New Economic Policy (NEP) that the country needed time to heal its wounds and strengthen itself militarily. Daniel Orlovsky suggests, "The army not only represented a military force but also provided the formative experience for the first generation of Bolsheviks." It is not surprising, therefore, that the Soviet Union developed as a military-administrative state. Military ideology and military thinking permeated government, economy, and society. ${ }^{45}$

During this period, the immediate focus of Soviet foreign policy was survival and state interest. $^{46}$ In pursuit of this goal, commissariat of Foreign Affairs (Narkomindel) called for total disarmament. This call, not surprisingly, evoked nothing but skepticism in European capitals. Nonetheless, the Soviet Union did succeed in normalizing relations with neighboring countries and establishing full diplomatic relations with the United States in $1933 .^{47}$

By the late 1930s, the Soviet Union had largely accomplished its goal of recovering from the trauma of its birth and was a thoroughly militarized state. Soviet defense outlays in 1941 amounted to over 43 percent of the country's GNP. This massive amount of defense spending, however, could not compensate for the loss of experienced military leaders purged by Stalin during the 1930s. ${ }^{48}$ Because of this perception of weakness and vulnerability at the highest levels of Soviet leadership and despite an ideological view that included the inevitability of war between the capitalist world and the communist world, the government remained on the

\footnotetext{
${ }^{44}$ Husband, "The New Economic Policy (Nep) and the Revolutionary Experiment 1921-1929," 274.

45 Orlovsky, "Russia in War and Revolution 1914-1921," 257.

${ }^{46}$ Husband, "The New Economic Policy (Nep) and the Revolutionary Experiment 1921-1929," 272.

47 Siegelbaum, "Building Stalinism 1929-1941," 316.

${ }^{48}$ Fuller, "The Great Fatherland War and Late Stalinism 1941-1953," 321-22.
} 
defensive, and continued to postpone the actual outbreak of the coming conflict until the Soviet Union was in a more advantageous position. ${ }^{49}$

With the triumph of the Nazis in Germany and the consolidation of a Japanese puppet state on the Soviet Union's eastern borders, the Communist International (Comintern) developed and implemented a strategy of Popular Fronts and an intensification of Soviet efforts to achieve collective security with the European democracies. These policies bore fruit in the form of mutual assistance pacts with France and Czechoslovakia in 1935, and the election of a Popular Front government in France in 1936. ${ }^{50}$

There was a limit, however, to the extent to which the European democracies were willing to cooperate with the Soviets. This limit was reached during the Spanish Civil War. Despite Soviet assistance to republican forces in Spain — or perhaps because the European democracies feared a communist Spain more than one ruled by Franco, the European democracies failed to prevent fascists from coming to power in Spain. The betrayal of Czechoslovakia at Munich in September 1938 confirmed Soviet suspicions that neither Britain nor France would come to the aid of the Soviet Union should Nazi Germany decide to expand eastward. $^{51}$

**Germany $(1816-1938) * *$

Between 1881 and 1887, Russia joined Germany and Austria in the Dreikaiserbund, and between 1887 and 1890, it signed two 'reinsurance' treaties with Russia. After Bismarck's

\footnotetext{
${ }^{49}$ Vagts, Defense and Diplomacy: The Soldier and the Conduct of Foreign Relations, 265.

${ }^{50}$ Siegelbaum, "Building Stalinism 1929-1941," 316.

${ }^{51}$ Ibid.
} 
dismissal, however, relations cooled between Russia and Germany. The Tsar then turned to France and Britain for diplomatic partners. ${ }^{52}$

By the time Vyshnegradskii left office and Witte took over, the Russian military-despite the misgivings of political conservatives and enemies of republicanism - had begun to see France as the most reliable ally for Russia and the best chance to balance against the rising power of Germany. By 1892, even a cautious Foreign Ministry, which was loathe to raise the ire of Germany, concluded its first, quite limited entente with Paris. By the end of the 1890s, both Russian economic and foreign policy were more oriented towards France than ever. This meant more potential conflict with Austria-Hungary, the Ottoman Empire, and ultimately with Germany itself. $^{53}$

In 1908, Vienna, at Russia's expense, unilaterally annexed the disputed Balkan provinces of Bosnia and Herzegovina and then reneged on a promised quid pro quo. This was embarrassing to Russia to say the least. Infighting between the army and the navy was depleting the budget and demoralizing the military. Plans for Russian domination of Mongolia and Manchuria no longer seemed plausible and were scaled back. There was also disagreement between key Russian decision makers regarding the issue of where to draw the line in terms of defending Russia against Germany and Austria. How far west should the line be drawn? ${ }^{54}$

Russian military planners, watching the Balkan Wars of 1912-13, committed to a "Western"-oriented strategy and planned for full rather than partial mobilization in the event of a major international crisis. ${ }^{55}$ As war became more likely in 1914 , the Russians wanted to avoid another humiliation in the Balkans. They also seemed to be losing their long quest to control the

\footnotetext{
${ }^{52}$ Davies, Europe: A History, 871.

${ }^{53}$ Zelnik, "Revolutionary Russia 1890-1914," 209.

${ }^{54}$ Ibid., 225-26.

55 Ibid., 226.
} 
Ottoman Empire and the Black Sea. Russia, as always, was also concerned with maintaining its great power status and did not want to be left behind. It also feared Germany's growing military and economic power. Its strategic and diplomatic ties to Britain and France further complicated matters and pulled Russia further into European politics and struggles. As Daniel Orlovsky puts it, "Like the other powers, Russia was unduly deferential towards strategic planning and the general staffs, the ideology of the offensive, and the illusion that war could be localized and won quickly." ${ }^{56}$

In the wake of the First World War, the Treaty of Rapallo opened the way for secret German-Soviet military co-operation. Germany would be able to conduct training and weapons testing (forbidden by the Treaty of Versailles) on Soviet soil. In return, the Russians would be able to increase its military prowess by learning from German military expertise. ${ }^{57}$

In the years leading up to the Second World War, the increasing likelihood of war in Europe prompted a radical shift in foreign policy away from seeking collective security with the Western democracies and towards an accommodation with Hitler. As mentioned earlier, after examining the democracies actions in Spain, the Soviets concluded that the West could not be relied upon to come to their assistance in the case of a Nazi attack. Therefore, Stalin signed the Soviet-German non-Aggression Pact of August 1939. Acting on a secret provision of that Pact, Soviet armed forces occupied eastern Poland, the three Baltic republics, and the Romanian province of Bessarabia. The Soviets also invaded Finland and eventually the Soviet army was victorious in the 'Winter War' of 1939-40. In the wake of these military adventures, the Soviet

\footnotetext{
${ }^{56}$ Orlovsky, "Russia in War and Revolution 1914-1921," 232.

${ }^{57}$ Husband, "The New Economic Policy (Nep) and the Revolutionary Experiment 1921-1929," 273-74.
} 
government fed its citizens a steady diet of Soviet patriotism accompanied by a massive build-up of the armed forces and defense industries. ${ }^{58}$

Unfortunately, the Soviet leadership failed to understand the nature of Nazi war doctrine. For example, the Soviet leadership believed that a war with Germany would most likely start after an extended period of crisis, which would give the Soviet army time to mobilize. ${ }^{59}$ This failure to grasp the concept of blitzkrieg, and the aggressive nature of Hitler and Nazism, doomed the Soviet Union to a disastrous beginning once hostilities actually broke out.

**United Kingdom (1936-1946)**

The Soviet Union's relationship with the United Kingdom during the 1930s was largely one of non-interaction. Though its industrial output had soared and probably overtaken that of Britain, the Soviet Union had turned inward and was trying to build "socialism in one country." The trend in the Soviet Union, as with many other countries at the time, was toward autarky. The Soviet Union was in diplomatic isolation and deeply suspicious of the western democracies. Furthermore, because of military weakness and the purges of the 1930s, Stalin felt that his country was passing through a "danger zone" and therefore diplomacy designed to give the Soviet Union time to heal was the order of the day. The Soviet Union had joined the League of Nations in 1934 in hopes of getting some collective security benefits. ${ }^{60}$

From the British side, the psychological scarring that occurred after the First World War created a sense of isolation and a desire to stay out of Continental affairs. On the other hand, as suggested in the previous chapter, Russia was seen as a threat to India. During the 1930s, the

\footnotetext{
${ }^{58}$ Siegelbaum, "Building Stalinism 1929-1941," 316.

${ }^{59}$ Fuller, "The Great Fatherland War and Late Stalinism 1941-1953," 322.

${ }^{60}$ Kennedy, The Rise and Fall of the Great Powers: Economic Change and Military Conflict from 1500 to 2000 , 283-326.
} 
British were becoming conscious that their defensive resources were stretched very thinly, and that only through diplomacy could they hope to keep their empire intact and free from military attack. However, British policymakers could not get past their dislike of communism. They, therefore, could not see the Soviet Union as a potential ally against the fascist threat. ${ }^{61}$

**United States $(1816-1860) * *$

Alexander I wanted to eliminate tensions between Russia and the United States. To this end, a treaty was signed between the two countries in 1824 that reduced Russia's claims to Alaska to the area north of $54^{\circ} 40^{\prime}$ latitude. Freedom of navigation in the Pacific for both nations was also recognized. ${ }^{62}$

By 1857 , Alaska was seen as more of a liability than an asset, and the Russians were willing to sell it to the United States. Its sale was put on hold during the American Civil War, in which the Russian government was "markedly friendly" to the North. ${ }^{63}$ Russia decided to withdraw from North America and sold Alaska to the US in $1867 .{ }^{64 *}$

**Japan $(1860-1944) * *$

Japan, which was totally closed to the outside world until 1855, quickly learned European ways and established an empire of its own, first in Korea and then in China. ${ }^{65}$ When the Japanese emerged on the world stage, they felt no inhibitions with regard to aggressive war. On the eve of the Chinese-Japanese War of 1894, the Japanese shocked Secretary of State Gresham by telling

\footnotetext{
${ }^{61}$ Ibid., 315-18.

${ }^{62}$ Seton-Watson, The Russian Empire 1801-1917, 178-79.

${ }^{63}$ Ibid., 444.

${ }^{64}$ Davies, Europe: A History, 869.

* Since the United States overtook Russia in terms of power in the 1860s, this period concludes our interest in this case for this chapter. The issue of the American response to Russia/Soviet power will be addressed in the next chapter.

${ }^{65}$ Ibid., 851.
} 
him, "our situation at home is critical and war with China would improve it by arousing the patriotic sentiment of our people and more strongly attach them to the Government." However, it did not surprise the German ambassador in London when his Japanese colleague Baron Hayashi informed him that there was a predominant view in Tokyo that war with Russia was inevitable. Hayashi added that many influential politicians were advocating preventive war against Russia and that a strike should come sooner rather than later. Japanese generals were confident that their armies could not be defeated during the next two years, and the admirals were certain that the Japanese fleet was superior to the Russian fleet. ${ }^{66}$

Russia's Asian policy had become increasingly expansionist and aggressive since before the turn of the century. Russia, overall, was in a dominant position over the Japanese, but the Russians were unprepared when the island nation struck in February 1904. The Japanese felt compelled to action by the daily strengthening of Russia's military position in the Far East. ${ }^{67}$ The 1904-1905 war resulted in national humiliation for Russia. ${ }^{68}$ However, even in the wake of this disastrous conflict, in which Japan gained southern Manchuria and Korea (which it fully annexed in 1910) Russia continued to strive for great power status. However, its military position was weaker than ever and the growth of an ever more troublesome deficit made the costs of rearmament difficult to overcome. ${ }^{69}$

During their war for the control of China in the early and mid 1930s, the Japanese could never quite agree on who their next or ultimate enemy would be. For the army, Russia was originally the chosen enemy. The army plan was to fight the Soviets, when the timing was right, and with little or no assistance from the navy. If the Japanese military clique "foresee an eventual

\footnotetext{
${ }^{66}$ Vagts, Defense and Diplomacy: The Soldier and the Conduct of Foreign Relations, 296.

${ }^{67}$ Ibid.

${ }_{68}^{68}$ Zelnik, "Revolutionary Russia 1890-1914," 212.

${ }^{69}$ Ibid., 221.
} 
clash as inevitable," Joseph Grew, American ambassador to Japan, reported in July 1933, "it is quite possible that they may intend to strike before Soviet Russia gets stronger - and the time element is all in favor of the latter." However, for reasons that are more imperialistic than strategic, Japanese aggression eventually settled on the United States. ${ }^{70}$ In the end, the Soviet Union concluded a neutrality pact with Japan in April 1941, and was not inclined to join the war against them until after the war against Germany had been concluded. ${ }^{71}$

\section{$\underline{\text { Analysis }}$}

In this section, I assess the performance of my Domestic Politics Model of Prevention in predicting the outcome of Russian/Soviet policy during the periods under consideration.

Following the method of structured, focused comparison, each of the eleven questions posed in chapter three are answered, and then an overview of the model's performance is outlined for each question. The typology for this model appears in table 5.1 while the flowcharts for the individual cases appear in Appendix A.

\footnotetext{
${ }^{70}$ Vagts, Defense and Diplomacy: The Soldier and the Conduct of Foreign Relations, 321.

${ }^{71}$ Peter Lowe, The Origins of the Korean War, ed. Harry Hearder, Origins of Modern Wars (New York: Longman, 1986), 9. For a copy of the text of the Neutrality Pact see http://www.yale.edu/lawweb/avalon/wwii/s1.htm
} 
Table 5.1: A Typology of Preventive Action

\section{Causal Mechanisms}

\begin{tabular}{|c|c|c|c|c|c|}
\hline & & $\begin{array}{l}\text { Systemic } \\
\text { Structure/ } \\
\text { Polarity }\end{array}$ & $\begin{array}{l}\text { Internal } \\
\text { Power } \\
\text { Constraints/ } \\
\text { Offense vs. } \\
\text { Defense } \\
\end{array}$ & $\begin{array}{l}\text { Domestic } \\
\text { Political } \\
\text { Constraints/ } \\
\text { Pressures }\end{array}$ & $\begin{array}{l}\text { Ruler Belief } \\
\text { Systems/ } \\
\text { Perception of } \\
\text { Threats }\end{array}$ \\
\hline \multirow{4}{*}{ 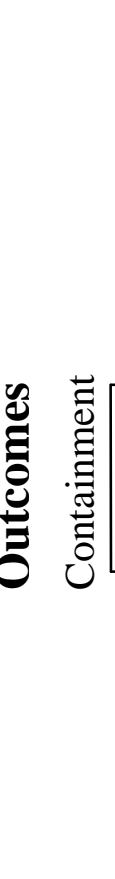 } & $\begin{array}{l}\text { Acquiescence/ } \\
\text { Do Nothing }\end{array}$ & $\begin{array}{l}\text { Bipolar/ } \\
\text { Balanced } \\
\text { Multipolar }\end{array}$ & $\begin{array}{l}\text { Severe/ } \\
\text { Defensive } \\
\text { Strategy }\end{array}$ & $\begin{array}{l}\text { Severe Political } \\
\text { Constraints/ } \\
\text { Pressure }\end{array}$ & $\begin{array}{l}\text { Moderate - } \\
\text { Acquiescent/ } \\
\text { Low - Non- } \\
\text { Militarized } \\
\end{array}$ \\
\hline & $\begin{array}{l}\text { Accommodation/ } \\
\text { Mix of Strategies/ } \\
\text { Carrot and Stick }\end{array}$ & $\begin{array}{l}\text { Bipolar/ } \\
\text { Balanced } \\
\text { Multipolar }\end{array}$ & $\begin{array}{l}\text { Moderate/ } \\
\text { Defensive- } \\
\text { Offensive } \\
\text { Strategy }\end{array}$ & $\begin{array}{l}\text { Moderate } \\
\text { Political } \\
\text { Constraints/ } \\
\text { Pressure }\end{array}$ & $\begin{array}{l}\text { Moderate - } \\
\text { Pragmatic/ } \\
\text { Moderate - } \\
\text { Non- } \\
\text { Militarized }\end{array}$ \\
\hline & \begin{tabular}{|l|} 
Initiate Sustained \\
Coercive/ \\
Confrontational \\
Diplomacy \\
\end{tabular} & $\begin{array}{l}\text { Bipolar/ } \\
\text { Unbalanced } \\
\text { Multipolar }\end{array}$ & $\begin{array}{l}\text { Moderate/ } \\
\text { Offensive- } \\
\text { Defensive } \\
\text { Strategy }\end{array}$ & $\begin{array}{l}\text { Moderate } \\
\text { Political } \\
\text { Constraints/ } \\
\text { Pressure } \\
\end{array}$ & $\begin{array}{l}\text { Pragmatic - } \\
\text { Militant/ } \\
\text { Moderate - } \\
\text { Militarized }\end{array}$ \\
\hline & $\begin{array}{l}\text { Initiate } \\
\text { Militarized } \\
\text { Preventive Action }\end{array}$ & $\begin{array}{l}\text { Unbalanced } \\
\text { Multipolar }\end{array}$ & $\begin{array}{l}\text { Minimal/ } \\
\text { Offensive } \\
\text { Strategy }\end{array}$ & $\begin{array}{l}\text { Minimal Political } \\
\text { Constraints/ } \\
\text { Pressure }\end{array}$ & $\begin{array}{l}\text { Militant - } \\
\text { Radical/ } \\
\text { High - } \\
\text { Militarized }\end{array}$ \\
\hline
\end{tabular}

1) To what extent is the internal power of the state constrained?

For much of Russia's history, it has taken an isolationist viewpoint. From the time of Alexander III, who abandoned direct intervention in Europe, to the leaders of the Soviet Union who wanted to wait until the time was right, Russia and then the Soviet Union was much less aggressive in foreign affairs than is often portrayed. ${ }^{72}$ For the first seventy years, the United States (1816-1860), Prussia/Germany (1816-1878), and Japan (1860-1873, 1878-1888) were the primary challengers to Russia. Though

\footnotetext{
${ }^{72}$ Davies, Europe: A History, 811.
} 
Russia was seen by other European powers as the most formidable power on the continent after the Napoleonic Wars, Russia seems to have always suffered from an inferiority complex. What we find throughout this period is a Russia that does not back down from an attack, but also does not go out of its way to get into trouble, particularly with the other great powers. Nonetheless, when Russia occupied territories of the Ottoman Empire in 1853, prompting Turkey to declare war on Russia, and then eventually forcing Britain and France to declare war on Russia, Russia fought for several years and then sought peace in 1856. This war showed some serious weaknesses of the Russian military. ${ }^{73}$ In the wake of the Crimean War, Russia underwent military and social reforms that prevented it from adopting an overtly offensive military doctrine.

From the 1890s, Russian leadership was bent on modernization. Heavy investment from the West helped increase industrialization dramatically. However, right up until the outbreak of the First World War, compared to other European powers, Russia continued to be economically backward. Russia's population also doubled between 1863 and 1913, but the economic backwardness of the country prevented many of these people from reaching their potential. The leadership in Russia, particularly after the Crimean War, seemed to be holding their breath hoping that the peace in Europe would last long enough for Russia to catch up with the other European powers. The war with Japan in 1904-1905, and Russia's humiliating defeat, did not help matters. Through all of this, then, we can conclude that the internal

\footnotetext{
${ }^{73}$ Dictionary of World History, (New York: Oxford University Press, 2000), 156-57.
} 
constraints on preventive action were quite strong up until the outbreak of the First World War. ${ }^{74}$

In terms of the above typology, I would argue that Russian and then Soviet leadership was severely to moderately limited in terms of internal power constraints and had a defensive or defensive-offensive strategy for most of this period. The typology, therefore predicts that Russia/Soviet Union would follow a policy of acquiescence or accommodation during these periods. In this category, the typology does a good job predicting actual Russian/Soviet behavior.

\section{2) To what extent are pro-preventive action elements constrained?}

Since the overwhelming outlook of Russia's leaders from 1816 up until the outbreak of the First World War was to maintain the peace between the major powers, pro-preventive action advocates were largely silent. Even those who were advocating an offensive military ideology were much more focused on preemption instead of prevention.

A similar mindset can be seen among the Soviet leadership after the First World War. Lenin and Stalin argued that what the Soviet Union needed was time to develop

\footnotetext{
74 Jack Snyder has argued that Russia, during the period leading up to the First World War maintained an offensive strategy because the Russian military leadership had such a high opinion of the German military that they felt the only way to turn the odds in their favor was by striking first. In looking closer at Snyder's study of Russian military planning during this period, however, it becomes clear that what Snyder is really talking about is preemption, not prevention. Offensive plans were in place, but they were predicated on the idea that Germany was about to strike France, with whom Russia had an alliance. It is also important to recognize that whatever offensive military posture the Russians may have had during this time, its posture was based on weakness rather than strength. The Russian military leadership was concerned that Germany would attack France and might rapidly defeat the inferior French forces, after which Germany would turn all of its attention on Russia. The Russian military leadership did not want to face the entire German army after a French defeat. In a sense, then, Russia's "offensive" strategy was really almost a defensive strategy. Russia was not going to mobilize because it thought it had something to gain by doing so, it was going to mobilize because it thought it had to before it lost whatever small advantage it might have. This, then, is a recipe for preemption, not prevention. See Jack Snyder, The Ideology of the Offensive: Military Decision Making and the Disasters of 1914, ed. Robert Jervis, Robert J. Art, and Stephen M. Walt, Cornell Studies in Security Affairs (Ithaca, New York: Cornell University Press, 1984), 157.
} 
its own resources and realize the potential of the vast country. Additionally, by putting off conflict with Western democracies, it would give the capitalist countries a chance to fight among themselves, thereby weakening themselves while the Soviet Union would be getting stronger. This would suggest that pro-prevention advocates would be largely silenced. This orientation toward avoiding conflict with the West should result in Russian and Soviet leadership that should be acquiescent and accommodating. Overall, again, the typology in figure 5.1 does a good job predicting Russian/Soviet behavior.

\section{3) What is the nature of the ruler belief system?}

From the time of Alexander I, Russian and then Soviet leaders tended to be pragmatists. Alexander helped create the European peace of 1816-1914, and his successors tended to follow suit. In the two major clashes Russia had with foreign powers between 1816 and 1913, Russia did not initiate military action. It did, however, take actions that prompted first Turkey and then Japan to declare war. Even these two moves: seizing the territory of a faltering Ottoman Empire in 1853 and reneging on its promise to withdraw troops from Manchuria in 1904-however can be seen as pragmatic moves given Russia's dominant power position. Of course, as we know, both moves ultimately turned out to be less than wise on the part of the Russian leadership.

William Husband notes:

In its foreign policy, a pragmatic internal logic governed Soviet behavior. Revolutionary Russia faced a hostile international community in 1921: the overthrow of tsarism by a mass movement had alarmed the ruling elites in the West, giving rise to the Red Scare. The Bolshevik state compounded such fears 
when it nationalized industry, including foreign-owned enterprises, and repudiated the pre-1917 national debt (much of which was held by foreign creditors). ${ }^{75}$

The period 1932-1946 seems quite similar to the previous periods, and for similar reasons. Communist ideology suggested that war amongst the capitalist countries was inevitable, and that if the Soviet Union just waited and built "socialism in one country," it would be the beneficiary of those wars. Lenin and Stalin both suggested that war between the Soviet Union and the capitalist countries was not inevitable, or at a minimum, should be put off as long as possible in order to build up the might of the Soviet state.

Similarly, Stalin from 1932 up until the Second World War took a pragmatic view of the international environment. He first attempted to achieve collective security by reaching out to France and Czechoslovakia in 1935, and then when the European democracies failed them in Spain, the Soviets turned to accommodation with Hitler. Stalin's primary goal was to give the Soviet Union time to build up its defenses. Whether relying on European democracies or by accommodating Hitler, his goal was to buy time.

Jack Snyder notes that the Soviets practiced what he calls "moderate expansionism" that reflected a dichotomy in Soviet strategic thought. Stalin, and other Soviet leaders, believed that the security of the Soviet Union required expansion and that real security for the country would only come when socialism replaced capitalism in the more advanced countries. Therefore, Soviet policy should promote the spread of socialism. However, the Soviet Union's early leaders also believed that

\footnotetext{
${ }^{75}$ Husband, "The New Economic Policy (Nep) and the Revolutionary Experiment 1921-1929," 273.
} 
if they exercised restraint in foreign policy, the capitalist countries would be more likely to focus their aggression on each other and leave the Soviet Union alone. ${ }^{76}$

Snyder notes further that while Stalin may have had a hostile image of the capitalist nations; Stalin was a pragmatist who saw few opportunities to strike first. Stalin, therefore, tried to avoid provoking the capitalist countries or getting involved in their squabbles. Instead, he attempted to build a military deterrent. Stalin himself, in 1925 , stated that if war comes "we shall have to take action, but we shall be the last to do so in order to throw the decisive weight into the scales." ${ }^{, 77}$ Furthermore, Snyder argues, "Stalin bent over backward to avoid provoking the Japanese and the Nazis.",78 For both Imperial Russia and the Soviet Union, then, the leadership was moderatepragmatic. This would suggest an accommodation strategy. If the conclusions reached here are accurate, the typology in figure 5.1 accurately predicts Russian/Soviet behavior.

\section{4) What is the nature of the threat (military, non-military)?}

Since both Imperial Russia and the Soviet Union were economically backwards and not reliant on global trade or distant colonies, most threats from other powers were seen as largely military in nature. Unlike Great Britain who had a widely spread empire and trading interests, Russia had relatively few economic ties to be threatened. For example, when Bismarck threatened France in 1875, Russia saw this as an attempt by Germany to start a war. Russia joined France and Britain in opposing the

\footnotetext{
${ }^{76}$ Jack Snyder, Myths of Empire: Domestic Politics and International Ambition, ed. Robert Jervis, Robert J. Art, and Stephen M. Walt, Cornell Studies in Security Affairs (Ithaca, New York: Cornell University Press, 1991 ), 212.

${ }^{77}$ Ibid., 213.

${ }^{78}$ Ibid., 219.
} 
German maneuver. This move by Russia, Britain, and France can be seen as a preventive action against Germany's attempts to start a preventive war. This is an interesting case of prevention to stymie prevention. Even the Russo-German tariff wars of the 1880 s cannot really be classified as preventive in nature. They were more protective than preventive.

In this case, then, military threats were the primary concern of Russian and Soviet leadership. Still, even with these perceived military threats, primarily from Prussia/Germany, they were seen as secondary threats since Germany was likely to attack towards the west before turning east. Russian military planners therefore faced what can be classified as a moderate-militarized threat. This would suggest that they would engage in sustained coercive or confrontational diplomacy. On this level, it seems that the typology in figure 5.1 does not do a particularly good job of predicting Russian/Soviet behavior. On the whole, between 1816 and the outbreak of World War II, accommodation seemed to be more the order of the times from the Russians.

\section{5) To what extent is conflict seen as likely or inevitable?}

We have seen that Alexander I was very involved in preserving peace in Europe and helped to establish the Concert of Europe. It does not appear that Russian leaders between 1816 and the outbreak of the First World War viewed conflict with any particular power as inevitable. On the contrary, Russian leadership wanted to avoid military conflict with the major powers whenever possible in order to allow Russia to develop its massive potential. 
The same can be said of the Soviet era up until the outbreak of World War II. Communist ideology dictated that eventually conflict would occur between the capitalist countries and the socialist countries, but Lenin thought that at least in the near future the two sides would be able to cohabitate. Stalin thought that by lying low, the Soviet Union might be able to sit out conflicts that were likely to occur among capitalist countries and that by doing so, the USSR would be in a powerful position should the day of reckoning come between the socialist and capitalist worlds. So, even in those quarters where conflict was seen as ultimately inevitable, it was thought to be advantageous to put it off as long as possible. The DPMP, therefore, would predict that preventive action would be unlikely and that if it did occur it would be non-militarized in nature. ${ }^{79}$ Under these conditions, our model predicts Russian/Soviet behavior fairly accurately.

\section{6) To what extent do domestic elements believe that a war would not be costly?}

The view that time was on their side prompted Russian military leaders to view war as more costly in the short term than it would be in the longer term when Russia would be in a stronger position. Russians in the imperial age and Soviets later respected Prussian/German military prowess and they went out of their way to avoid conflict with that nation. The same can be said of the Soviet Union's relations with Japan prior to the outbreak of the Second World War. It seems clear that these periods, Russian/Soviet leadership believed that general conflict was not worth the price. For these cases, the DPMP accurately predicts Russian/Soviet behavior.

\footnotetext{
${ }^{79}$ See Appendix A, especially Russia-US Threat, Soviet Union-United Kingdom Threat, and Russia-Japan 1913-
} 1944. 
Russia was less cautious towards Japan in 1904. It did not withdraw from Manchuria as it had previously agreed, and does not seem to have been overly concerned about war with Japan. It seems that conflict with Japan was seen as likely, but the Russian leadership felt they would be able to defeat the island nation at relatively little cost. Of course, we now know that Russia would pay a heavy price for its bungling. For this case, the DPMP predicts that Russia would have engaged in militarized preventive action. This did not occur since Japan attacked Russia. Our model fails in this case.

\section{7) To what extent is there the belief that a war now would be less costly than a war later?}

As already mentioned, quite the opposite is true. The Russian/Soviet leadership felt that the future was brighter for their country than the present and that a war now would be more costly than a war later. In the view of the leadership, Russia/the Soviet Union had immense resources; it just needed time in which it could develop those resources into military and economic power. On this level, the DPMP somewhat predicts Russian/Soviet behavior.

The DPMP predicts that the dominant power is likely to take non-militarized preventive action under these conditions. In some cases Russia/the Soviet Union engaged in this type of behavior, but more often than not it simply acquiesced or accommodated the challenger ${ }^{80}$ For example, in regards to Germany during the 1932-1938 period, the Soviets first tried to align themselves with the West against Germany, but failing that, they signed non-aggression pacts with both Germany and

\footnotetext{
${ }^{80}$ See Appendix A: Russia/Soviet Union-Prussia/Germany Threat.
} 
Japan. Therefore, we must conclude that the DPMP does not accurately predict Russian/Soviet behavior under these conditions.

8) To what extent is there the belief that the chances of winning a war now would be greater than the chances of winning a later war?

Again, the leadership of Russia/the Soviet Union was confident that over time, their power would grow, and therefore the longer they could put off a war, the better their chances would be to win the conflict. Similar to the last condition, our Domestic Politics Model of Prevention again predicts that Russia/the Soviet Union was likely to engage in non-militarized preventive action. This once again holds true in some instances, but not in others. See Appendix A: Russia/Soviet Union-Prussia/Germany Threat.

9) To what extent do domestic elements think the status quo will get worse for their state if the rising challenger is allowed to continue its ascendancy?

In all of the cases with the exception of the United States, Russian leadership felt that in the end, Russia would emerge as more powerful than its challengers. They were hopeful that the future belonged to them. When it came to the U.S., however, they almost seemed resigned to a power sharing agreement. The Russian withdrawal from North America and consolidation of power in Asia and Europe suggests that from an early date, Russian leadership was seeing the world in terms of a Russian sphere of influence and an American sphere of influence. 
I would argue, however, that though Russian leadership in the 1850s and 1860s did not see the future as particularly bright vis-à-vis the United States, this was of little concern to them. Their focus was on Asia and Europe, not on North America. In Appendix A: Russia-US Threat, therefore, I have answered "no" to the question "Will status quo continue to worsen if no action is taken?" From my research, there was not an overwhelming concern about the rise of the United States on the part of the Russian leadership.

As long as the Russian/Soviet leadership did not feel that the status quo was getting worse (or in the case of the US - they did not care if it would get worse), the DPMP predicts that preventive action was unlikely or that should there by preventive action it was likely to be non-militarized in nature. My model seems to do a good job of predicting Russian/Soviet behavior under these conditions.

\section{0) What is the nature (polarity) of the international system?}

John Mearsheimer suggests that the period 1816-1902 was characterized by balanced multipolarity (war somewhat likely), while the period 1903-1918 was characterized by unbalanced multipolarity (war most likely). 1919 to 1938 constituted a balanced multipolar system (war somewhat likely) while 1939 to 1945 was an unbalanced multipolar system (war most likely). According to his theory of offensive realism, war was therefore somewhat likely from 1816 to 1902 and again from 1919 to 1938 . War was most likely during the periods $1903-1918$ and 1939 to $1945 .{ }^{81}$ One question this theory does not answer is this: Why did war occur in 1914 and not, in

\footnotetext{
${ }^{81}$ See John J. Mearsheimer, The Tragedy of Great Power Politics (New York: W. W. Norton \& Company, 2001).
} 
say 1910 when the structure was the same? Mearsheimer's model comes up short in answering this puzzle.

The typology of preventive action developed in this study also incorporates Mearsheimer's concepts of polarity (see table 5.1 above). Within the typology, a "Balanced multipolar" system suggests that Russia should have acquiesced or have used a mixed strategy, which is at least partially correct. However, in the later "unbalanced multipolar" system, the typology predicts that Russia should have used coercive/confrontational diplomacy. On this point, the typology does not do a good job of accurately predicting the behavior of Russia/the Soviet Union.

\section{1) What type of government exists in each state, i.e., are either or both democracies? ${ }^{82}$}

Between 1816 and 1879, Russia is classified as an autocracy as is Prussia/Germany. During this period, Japan is classified as an anocracy. The United States was a full democracy during this period. Therefore, according to Schweller's model, Russia should have either formed a defensive alliance or initiated preventive war against Germany/Prussia, Japan, Russia, and the U.S. ${ }^{83}$

Russia was a key player in the Concert of Europe and was active in European affairs, particularly under the rule of Alexander I and Nicholas. Many of the agreements reached during this period could be viewed as defensive alliances, so

\footnotetext{
${ }^{82}$ See Ibid. See also Randall L. Schweller, "Domestic Structure and Preventive War: Are Democracies More Pacific?," World Politics 44, no. 2 (1992).

${ }^{83}$ All statements about the level of democracy are based on the Polity IV rating. If a state is rated 7 to 10 , then I consider it a full democracy. If it is rated a 1 to 6 it is an anocracy, and I treat it as a non-democracy. States receiving a zero or negative rating are considered autocracies by Polity IV. See Appendix C for selected Polity IV scores.
} 
Schweller's model seems to hold up during this time. However, Russia did not engage in preventive war, or preventive action of any kind during this entire period.

From 1880 to 1896, Russia and Germany were classified as autocracies. The UK is classified as a full democracy and Japan is classified as an anocracy. Therefore, Russia should have formed a defensive alliance or initiated preventive war against Germany, Japan, the UK and the United States. Russia continued to be involved in European affairs, but not in an overly aggressive way. Defensive agreements were made, but no real preventive action was taken.

From 1897 to 1902, Russia and Germany were still autocracies. Japan was still classified as an anocracy while the United States and the United Kingdom are classified as full democracies. ${ }^{84}$ Therefore, Russia should have formed a defensive alliance or initiated preventive war against Germany, Japan, the UK and the United States. Again, Schweller's model somewhat predicts what Russia did during this time. Russia did not engage in preventive war, but its agreements at the Hague and elsewhere could be seen as entering into defensive alliances with other powers.

During 1903 and 1904, Russia is classified as an autocracy while Japan is classified as an anocracy. Therefore, Russia should have formed a defensive alliance or initiated preventive war against Japan. In reality, Russia did neither. It attempted to continue its expansion in Asia, but Russia was humiliated when Japan launched a war against it in an attempt to put a halt to its expansionist dreams in Asia.

Until 1906, Russia was still an autocracy and Russia's rulers refused to recognize any law that could not be subordinated to or reversed by the autocrat. ${ }^{85}$ In 1906 , the

\footnotetext{
${ }^{84}$ Japan was undergoing an "adverse transition" from 1860 to 1867, and then it was an anocracy.

${ }^{85}$ Zelnik, "Revolutionary Russia 1890-1914," 201.
} 
government of Russia underwent a significant change. On 23 April 1906, Russia formerly acquired a constitution, though it was flawed in several ways. Despite its shortcomings, it did have at least the potential to put some restrictions on the tsar's ability to increase military budgets. This now had to be approved by the Duma. ${ }^{86}$

Between 1906 and 1918, Russia and Japan are classified as anocracies. Therefore, Russia should have formed a defensive alliance or initiated preventive war against Japan. What we really see, though, is a turning inward and westward by Russia during this time. With the Japanese in Manchuria and Korea, there was less incentive for Russia to continue attempted expansion in Asia. In any case, the events in Europe began to demand more attention than events in Asia.

Between 1932 and 1946, the Soviet Union is classified as an autocracy. Germany is classified as an anocracy in 1932, but then is classified as an autocracy between 1933 and 1944. Japan is classified as an anocracy between 1932 and 1944. The United Kingdom is classified as a democracy between 1932 and 1946. Therefore, Russia should have formed a defensive alliance or initiated preventive war against all of these powers. Of course, this did not happen. The Soviet Union did not engage in preventive action during this period, and several of the agreements that it entered into were not defensive against these powers. The Soviet-German non-Aggression Pact of August 1939 was not a defensive alliance against Germany, as would be predicted by the Schweller model. Schweller's model seems to fail spectacularly in predicting Russian Soviet behavior. All of these periods and predictions are summarized in table 5.2 .

${ }^{86}$ Ibid., 221. 
Table 5.2 Mearsheimer's and Schweller's Predicted Outcomes

Regime Type

Predicted Russian/Soviet Action

\begin{tabular}{|c|c|c|c|c|c|c|}
\hline \multirow[t]{2}{*}{ Time Period } & Power Distribution & \multirow{2}{*}{ Russia/Soviet Union } & \multirow{2}{*}{$\mathbf{U K}$} & \multirow{2}{*}{ Prussia/Germany } & \multirow{2}{*}{ Japan } & \multirow{2}{*}{ US } \\
\hline & Predicted Outcome & & & & & \\
\hline \multirow[t]{2}{*}{$1816-1879$} & Balanced Multipolar & \multirow[t]{2}{*}{ Autocracy } & & Autocracy & Anocracy & Democracy \\
\hline & War Somewhat Likely & & & $\begin{array}{c}\text { Defensive Alliance or } \\
\text { Preventive War }\end{array}$ & $\begin{array}{l}\text { Defensive Alliance } \\
\text { or Preventive War }\end{array}$ & $\begin{array}{l}\text { Defensive Alliance } \\
\text { or Preventive War }\end{array}$ \\
\hline \multirow[t]{2}{*}{$1880-1896$} & Balanced Multipolar & \multirow[t]{2}{*}{ Autocracy } & & & Anocracy & \\
\hline & War Somewhat Likely & & & & $\begin{array}{l}\text { Defensive Alliance } \\
\text { or Preventive War }\end{array}$ & \\
\hline \multirow[t]{2}{*}{$1897-1902$} & Balanced Multipolar & \multirow[t]{2}{*}{ Autocracy } & & & Anocracy & \\
\hline & War Somewhat Likely & & & & $\begin{array}{l}\text { Defensive Alliance } \\
\text { or Preventive War }\end{array}$ & \\
\hline \multirow[t]{2}{*}{ 1903-1904 } & Unbalanced Multipolar & \multirow[t]{2}{*}{ Autocracy } & & & Anocracy & \\
\hline & War most likely & & & & $\begin{array}{l}\text { Defensive Alliance } \\
\text { or Preventive War }\end{array}$ & \\
\hline \multirow[t]{2}{*}{$1905-1913$} & Unbalanced Multipolar & \multirow[t]{2}{*}{ Anocracy* } & & & Anocracy & \\
\hline & War most likely & & & & $\begin{array}{l}\text { Defensive Alliance } \\
\text { or Preventive War }\end{array}$ & \\
\hline \multirow[t]{2}{*}{ 1914-1918 } & Unbalanced Multipolar & \multirow[t]{2}{*}{ Anocracy } & & & Anocracy & \\
\hline & War most likely & & & & $\begin{array}{l}\text { Defensive Alliance } \\
\text { or Preventive War }\end{array}$ & \\
\hline \multirow[t]{2}{*}{$1932-1938$} & Balanced Multipolar & \multirow[t]{2}{*}{ Autocracy } & Democracy & Autocracy** & Anocracy & \\
\hline & War Somewhat Likely & & $\begin{array}{l}\text { Defensive Alliance } \\
\text { or Preventive War }\end{array}$ & $\begin{array}{c}\text { Defensive Alliance or } \\
\text { Preventive War }\end{array}$ & $\begin{array}{l}\text { Defensive Alliance } \\
\text { or Preventive War }\end{array}$ & \\
\hline \multirow[t]{2}{*}{ 1939-1945 } & Unbalanced Multipolar & \multirow[t]{2}{*}{ Autocracy } & Democracy & Autocracy & Anocracy & \\
\hline & War most likely & & $\begin{array}{l}\text { Defensive Alliance } \\
\text { or Preventive War }\end{array}$ & $\begin{array}{c}\text { Defensive Alliance or } \\
\text { Preventive War }\end{array}$ & $\begin{array}{l}\text { Defensive Alliance } \\
\text { or Preventive War }\end{array}$ & \\
\hline
\end{tabular}

* Russia was in turmoil in 1905 and therefore there is no Polity IV data for that year for Russia. Russia is classified as an anocracy starting in 1906.

**For 1932, Germany is actually classified as an anocracy, but then in 1933 its classification reverts to autocracy.

Blank boxes indicate that Russia/the Soviet Union was no longer in relative decline vis-à-vis the other power or the other power had surpassed Russia/the Soviet

Union. Either condition is outside the scope of this research. 


\section{Conclusion}

Russian and Soviet leadership had a largely optimistic view of the future for their state. Despite chronic economic and military weakness, both Imperial Russia and the Soviet Union saw themselves as great powers at least equivalent to the most powerful states in Europe, Asia, and North America. Moreover, their belief that time was on their side and that they would only continue to get stronger led to a belief that conflict with other great powers should be avoided whenever possible. This was taken to an extreme in communist ideology, which suggested that the capitalist nations would fight amongst themselves, and a neutral Soviet Union would be the true beneficiary of such a conflict.

This optimism about the future precluded a strong preventive school of thought from taking root in either Imperial Russia or the Soviet Union. Russia and the Soviet Union both largely accommodated rising powers, in much the same way that Britain had done, though for very different reasons. British leadership was largely resigned to a fate of declining power, while Russian and Soviet leadership were optimistic about their power potential.

In the case of Russia and the Soviet Union, the typology and model developed for this research project perform about as well as Mearsheimer's polarity model and better than Schweller's democracy model. Where the DPMP does fail (nature of threat, expected cost of war, perceived chances of winning a war), it does not fail completely. Unfortunately, because it is correct some of the time while missing the mark at other times, we must conclude that on these dimensions, it performs poorly as a predictor of Russian/Soviet behavior. 


\section{Chapter Six \\ The Decline of the United States}

This chapter examines the decline of the United States vis-à-vis several rising powers from the middle of the nineteenth century to the close of the twentieth century. The first section of this chapter is meant to serve as a very brief overview of America's rise to power and its foreign policy. The rest of the chapter will delve into particular aspects of America's relative decline, the specific threats to its dominance of the Western Hemisphere and the international system, and its reaction to those challenges.

\section{A Brief Overview of American Power and Foreign Policy}

The story of the United States' rise to prominence begins in 1783, but even as early as 1776; the rebellious colonies were showing signs of their future greatness. In that year, by some accounts, the Americans were producing more pig iron and bar iron than Great Britain. ${ }^{1}$ By the 1770s, New Englanders may have been the wealthiest people in the world with per capita incomes that were at least equal to that in Great Britain. New Englanders also had bigger farms, bigger families, and better educations than their counterparts living in the old country did. ${ }^{2}$ Furthermore, victory against Great Britain in the Revolutionary War (1775-83) ensured independence for the American colonists and began the long process of the breakup of the British Empire. ${ }^{3}$

The march forward for the new nation would not be without its challenges and pitfalls, however. After the Napoleonic Wars in Europe, Britain and the major powers in Europe reacted

\footnotetext{
${ }^{1}$ Paul Kennedy, The Rise and Fall of the Great Powers (New York: Vintage Books, 1987), 93-94.

${ }^{2}$ Niall Ferguson, Empire: The Rise and Demise of the British World Order and the Lessons for Global Power (New York: Basic Books, 2002), 70.

${ }^{3}$ Paul W. Schroeder, The Transformation of European Politics 1763 - 1848, ed. Lord Bullock and William Deakin, Oxford History of Modern Europe (New York: Oxford University Press, Inc., 1994), 11.
} 
negatively to liberal revolutionary movements. In Europe, there was a movement back toward monarchism. The "Holy Alliance"—made up of Russia, Austria, and Prussia—vowed to deal with countries whose governments had been changed by revolution. Americans were obviously concerned about this wave of anti-liberalism, but they were also absorbed in their own domestic affairs and a looming civil war. ${ }^{4}$

In the wake of its civil war, the United States emerged more powerful and influential than ever. By the end of the 1870 s, the U.S. ranked among the richest countries in the world. ${ }^{5}$ The historian John Lewis Gaddis notes that by the 1860s, it was already becoming clear to the rest of the world that the United States' industrial strength and military might was becoming formidable. He argues, however, that Americans were never very comfortable with the power they accumulated and they were not always confident of their ability to wield power wisely. The foreign policy of the U.S. was, he asserts, "curiously unassertive.",

By the mid-1890s, despite greatly increased power, the U.S. continued to show apprehension in wielding its new power. For example, even though it created a colony in the Philippines, the U.S. government almost immediately saw this as a mistake and began to prepare the Filipino people for independence. Furthermore, the U.S. refused to turn Cuba into a colonial possession. Even after the First World War, the United States dismantled its military and then rejected Woodrow Wilson's primary vehicle, the League of Nations, for exercising American power. ${ }^{7}$ It would take another global conflagration to convince Americans that their leadership in world matters could be beneficial.

\footnotetext{
${ }^{4}$ Robert Kagan, Dangerous Nation: America's Place in the World from Its Earliest Days to the Dawn of the Twentieth Century (New York: Alfred A. Knopf, 2006), 157-59.

${ }^{5}$ Ibid., 301.

${ }^{6}$ John Lewis Gaddis, The United States and the End of the Cold War: Implications, Reconsiderations, Provocations (New York: Oxford University Press, 1992), 5-6.

${ }^{7}$ Ibid.
} 
After the Second World War, the United States chose to be much more engaged in global affairs. In July 1944, at the Bretton Woods (New Hampshire) Conference, the United States took the lead in formulating a postwar monetary and economic system. ${ }^{8}$ It also oversaw the creation of the United Nations and other international mechanisms designed to prevent another global conflict. With the onset of the global struggle with the Soviet Union in the wake of the Second World War, American involvement on the world stage was entrenched. With the fall of the Soviet Union and the apparent triumph of democracy, the United States became the sole superpower and the undisputed leader of the international system.

Despite its dramatic rise to power, the United States did not go unchallenged. The Soviet Union confronted the United States at various times during the twentieth century. Prussia and then Germany posed concerns for the United States from the late 1840s through the end of the 1930s. Japan challenged the United States for supremacy in Asia and elsewhere periodically from the mid-1860s up through the early 1980s. The United Kingdom, though an ally of the United States, also grew in power relative to the U.S. at various times between 1930 and 1996. The rest of the chapter will examine these challenges to American dominance and how the U.S. responded to these challenges.

\section{$\underline{\text { Power Relations }}$}

\section{$\underline{\text { United States vis-à-vis Russia/Soviet Union }}$}

Between 1816 and 1860, Russia was in a dominant position over the United States. In 1861, the United States surpassed Russia and maintained that dominance, with only short breaks

\footnotetext{
${ }^{8}$ Warren I. Cohen, America in the Age of Soviet Power, 1945-1991, ed. Warren I. Cohen, vol. IV, The Cambridge History of American Foreign Relations (New York: Cambridge University Press, 1993), 4.

${ }^{9}$ As mentioned in previous chapters, in order to assess power shifts after 1816, I use the Composite Index of National Capability (CINC) score derived from the National Material Capabilities (v3.02) index. This is part of the Correlates of War (COW) project and can be accessed at http://www.correlatesofwar.org/.
} 
until the early 1970s. However, between 1863 and 1970, there were three periods in which the United States, while still dominant, was in relative decline to either Russia or the Soviet Union. These will be explored in detail in this chapter. See figure 6.1 below.

\section{Figure 6.1}

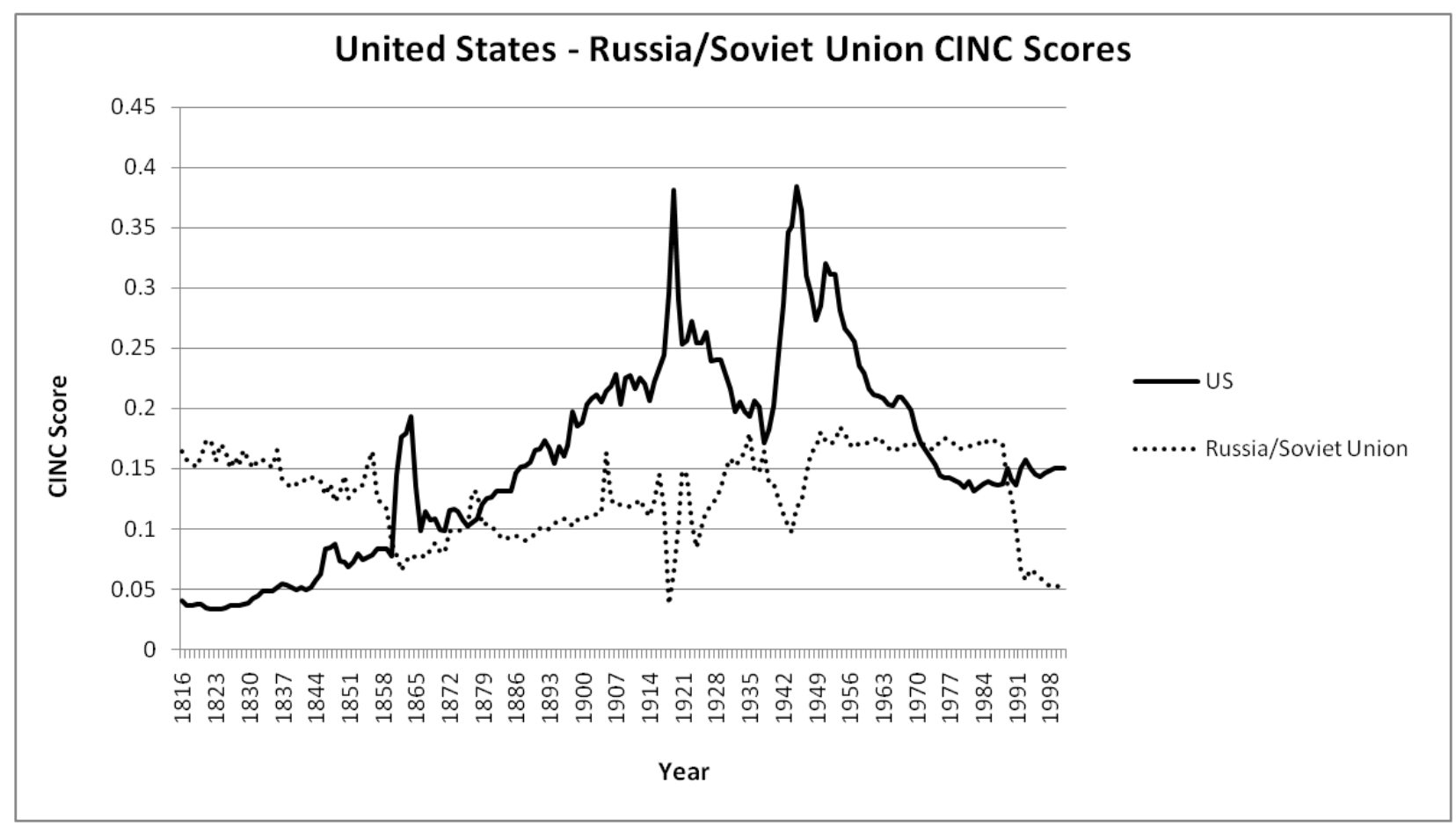

United States vis-à-vis the United Kingdom

In 1892, the United States reached parity with the United Kingdom. However, it was not until 1897 that the U.S. successfully took the lead for good. Still, as was the case with Russia, the U.S. was in relative decline vis-à-vis the UK at various times during the twentieth century. We will examine these periods of relative decline in this chapter. See Figure 6.2 below. 


\section{Figure 6.2}

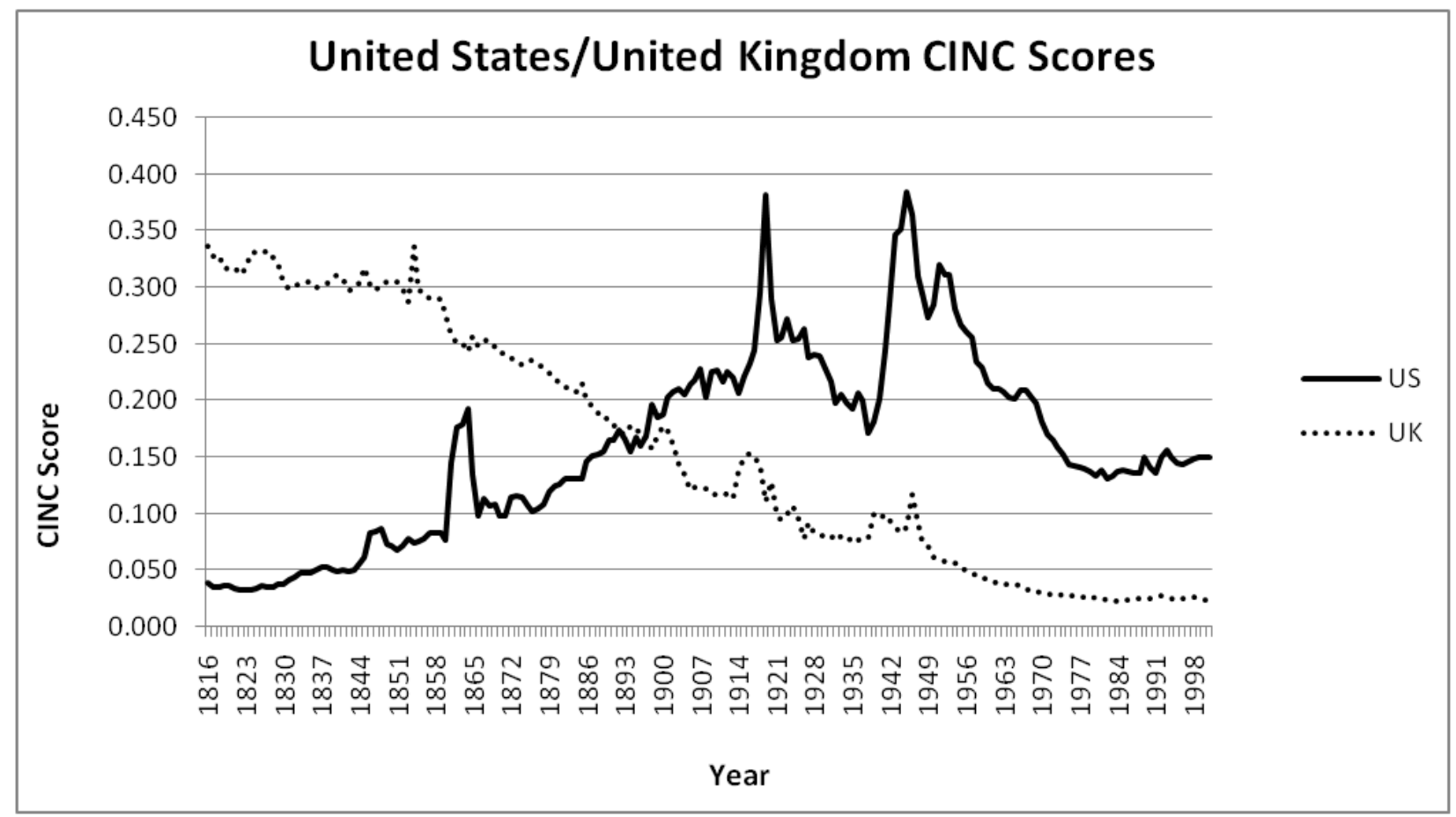

$\underline{\text { United States vis-à-vis Prussia/Germany }}$

In the year 1844, the United States matched the power of Prussia for the first time. For most of the next century and a half, the United States would maintain a dominant position over the Prussian and then the German state. There were three periods during the nineteenth and twentieth centuries, however, in which the U.S. did decline relative to Prussia and Russia. We will study these periods in this chapter. See Figure 6.3 below. 


\section{Figure 6.3}

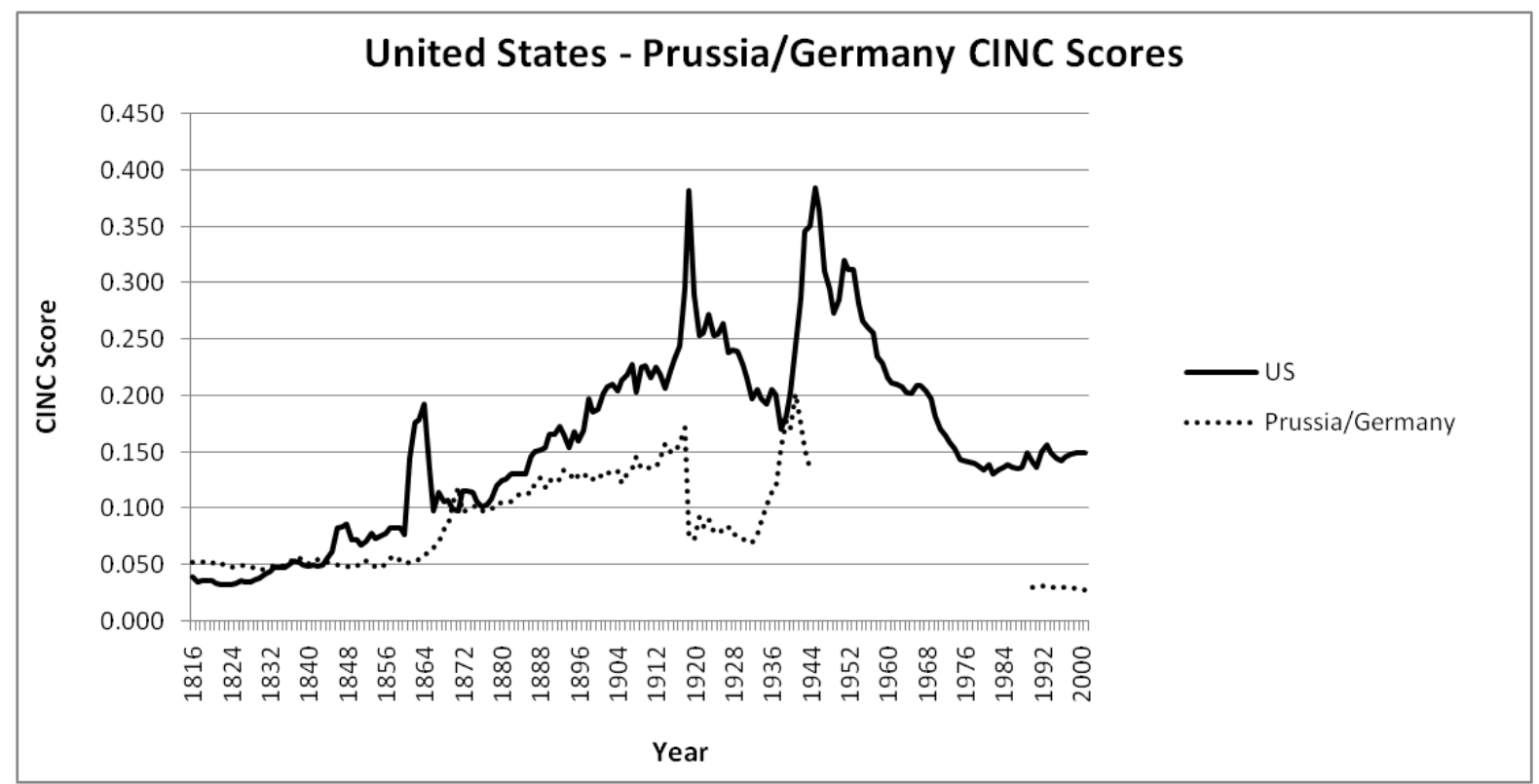

$\underline{\text { United States vis-à-vis Japan }}$

The United States has dominated the relationship with Japan since the island nation joined the modern international system in the 1860s. Like the other relationships outlined above, however, there were periods in the nineteenth and twentieth centuries in which the U.S. declined relative to Japan. These periods will be examined in this chapter. See Figure 6.4 below. 


\section{Figure 6.4}

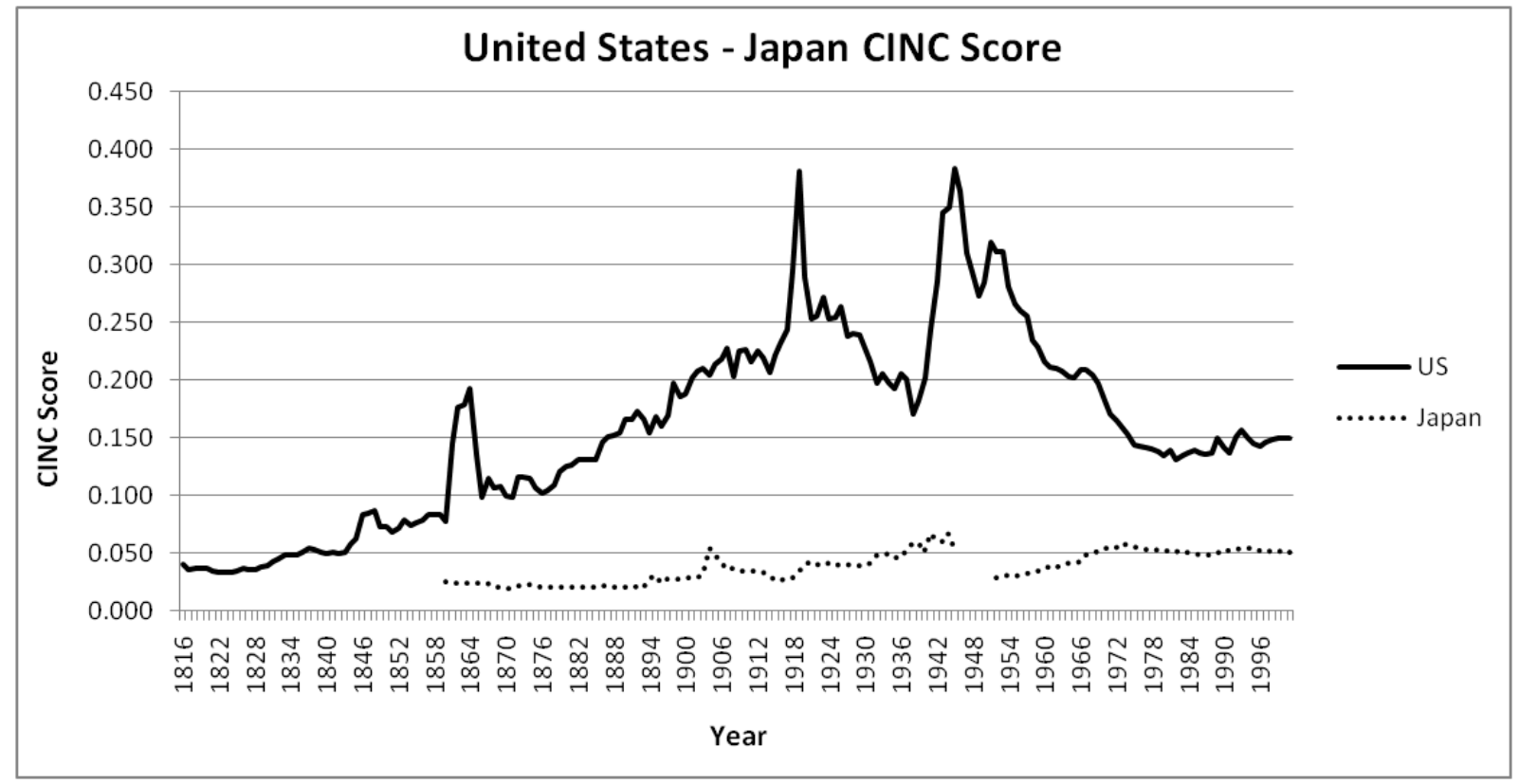

In summary, this chapter examines the following instances in which the United States

was in a dominant but relatively declining position in relation to the challenger:

United States - Russia/Soviet Union: 1863 - 1875, 1925 - 1938, 1946 - 1970

United States - Prussia/Germany: 1849 - 1858, 1873 - 1888, 1920 - 1939

United States - Japan: 1865 - 1876, 1930 - 1939, 1952 - 1982

United States - United Kingdom: 1930 - 1939, 1946 - 1996

\section{Nature of the Threat}

Robert Kagan argues that Americans in the nineteenth century did not view the world through the lens of power but instead "evaluated other nations and their relationship to the United States according to where they stood on the continuum of progress." Some nations were advancing on this continuum at a rapid pace, some were moving ahead more slowly, and others were not moving at all or perhaps even sliding backward. In the contemporary American view, the global achievement of Western liberal civilization was the ultimate goal, since Americans 
equated progress and civilization with peace and their own national security. They believed that the more advanced, liberal, and commercial a people were, the more attuned they would be to modern concepts of justice and morality and the less inclined to war and aggression. ${ }^{10}$

This view of the world as a continuum of progress and civilization helped Americans organize their international affairs. It created a moral compass by which countries could be judged "bad," "good," "improving," etc. The more backward and despotic a nation, the more dangerous it was considered. Russia was usually viewed in this light. Germany too was seen as backward and repressive as the expectation of budding liberalism faded. These countries were considered dangerous both because their concepts of justice and morality were less developed than liberal democracies, and because they retained the warlike spirit characteristic of societies in the "barbaric" stage.

Kagan notes that these moral judgments often blurred into strategic judgments. Since Russia was "bad," it needed to be constantly scrutinized and beaten back when necessary. Some Americans were also concerned that advanced liberal societies like the United States were in danger of losing the martial spirit necessary to defend themselves, and therefore civilizing the world's barbaric peoples was all the more urgent. The world had to be made safe for civilized peoples before they lost the will or the capacity to destroy the barbarians.

On a more positive side, many Americans saw “opening” other nations to commerce in the American interest not only because of the possibility of making money, but also because of a belief that over time commercial interaction would lead to the progress of backward peoples toward civilization. They would become more liberal, more commercial, and therefore less threatening to the United States and to the civilized world in general. The spread of

\footnotetext{
${ }^{10}$ Kagan, Dangerous Nation: America's Place in the World from Its Earliest Days to the Dawn of the Twentieth Century, 296.
} 
civilization would bring order worldwide through the spread of morality and the reinforcement of virtue. For example, Japan was often viewed as a good candidate for progress and on the path toward western style liberalism. It, therefore, could be allowed to expand at Russia's expense without causing much concern. ${ }^{11}$

\section{Economic Challenges}

In the late nineteenth century, the United States emerged as an economic powerhouse. Europeans warned of an "American invasion" of U.S.-made goods and U.S. based multinational corporations long before they worried about U.S. military, political, or cultural power. One example of this was that by 1914, Russia's largest integrated commercial enterprises were two American based multinational corporations: Singer Sewing Machine and International Harvester. ${ }^{12}$ During the twentieth century, this economic prowess would only grow, but there were challenges to this dominance.

\section{**Russia/Soviet Union**}

Russia and then the Soviet Union never presented much of an economic threat to the United States, with the exception of the mid 1880s, when Russia represented an economic challenge for the United States primarily in terms of oil. ${ }^{13}$

\footnotetext{
${ }^{11}$ Ibid., 296-97.

${ }^{12}$ Walter LaFeber, The American Search for Opportunity, 1865 - 1913, ed. Warren I. Cohen, vol. II, The Cambridge History of American Foreign Relations (New York: Cambridge University Press, 1993), 21-29.

${ }^{13}$ Ibid., 3. Unfortunately, this time period does not fall within the parameters being used for this study. The Soviet Union did, of course, present a major military and ideological challenge to the United States, and that is covered later in this chapter.
} 
**Prussia/Germany**

The primary period of German economic challenge to the United States (at least for the purposes of this study) was during the 1870s and1880s. During this period, German commercial interests were growing in Latin America. By the 1880s, Germany was second only to the British in Costa Rica's coffee export industry. The Germans were also becoming a dominant force in Guatemala, Nicaragua, and El Salvador. German commercial interests in the area also manifested other, perhaps more threatening, undertones. In the 1870s, Berlin sent a six-ship war fleet to Nicaragua to protect German investors and collect an indemnity. In the early 1880 s, the German minister to the region accused the United States of harboring imperial designs on the region. At the same time, Germany attempted to establish naval bases and colonies in the region. Secretary of State James G. Blaine responded to these challenges to U.S. leadership in Latin America by pushing for a Pan-American movement. The united response of the various American nations was so negative that German Chancellor Otto von Bismarck had to make a tactical retreat. ${ }^{14}$

$* * \operatorname{Japan} * *$

Early conflicts between the United States and Japan, though occurring during a period of relative American decline, are not at all clearly of a preventive nature. For example, Japan, still trying to close itself off from the West in 1864, apparently burned the U.S. legation. It then closed the Strait of Shimoneseki to all foreign shipping. Secretary of State William H. Seward reacted viscerally to any nation that tried to shut itself off from trade. He saw such moves as unnatural and immoral. Seward especially grew angry because the Japanese opposed the promotion and practicing of Christianity. Because of these indignities, the U.S.S. Wyoming

\footnotetext{
${ }^{14}$ Ibid., 72.
} 
joined British, French, and Dutch ships that blasted their way into the Strait of Shimoneseki and then, in 1866 , dictated trade treaties. ${ }^{15}$ It is difficult to characterize these actions as preventive. On the contrary, they seem to be actions designed to open Japan to the West and thus, at least in accordance with the thinking of the time, advance its development.

Beginning in 1868, Japan transformed its government and committed to modernize the country along Western industrial lines. The U.S. minister to Japan in the mid-1870s, Judge John A. Bingham, rewarded the Japanese by showing sympathy to Japanese demands for tariff autonomy. He also understood that U.S.-Japan cooperation could undercut the powerful British position in the Japanese market. ${ }^{16}$

Japan again challenged American economic dominance in the decades following the Second World War. In the early 1960s, Prime Minister Ikeda Hayato decided that Japan would adopt a policy of "low posture" on defense and would avoid international quarrels, concentrating instead on economic development. This was the beginning of the Ikeda "income-doubling" program that led ultimately to the Japanese "economic miracle." Still, it was not until the 1970s that Japanese automobiles, TV sets, and other electronic products began to make serious inroads into the American market. Once this did occur, however, it created problems for American companies. This in turn aroused strong congressional sentiment and heralded the era of "Japanbashing" in the late 1970s and early 1980s. This challenge had created economic, political, and philosophical conditions that were taxing the viability and strength of the U.S.-Japan alliance.

\footnotetext{
${ }^{15}$ Ibid., 18-19.

${ }^{16}$ Ibid., 95-96.
} 
Competition between the two nations was turning adversarial, so that rivalry rather than accommodation set the tone. ${ }^{17}$

Although the 1960s started out inauspiciously, the decade saw the beginning of the remarkable economic growth that was to bring Japan in a few years to the position of third greatest economic power in the world. The Korean War (1950-1953) provided a sharp spurt to Japan's economy, as American procurement for the war could be most economically accomplished in Japan. The period thereafter, especially the 1960s, became Japan's takeoff for economic growth, averaging in excess of 10 percent per year throughout the decade. In 1962, the Gross National Product (GNP) was already three times that of the prewar period 1934-1936. ${ }^{18}$

Until 1965, the United States exported more goods to Japan than it imported; but in that year, the balance turned the other way. By 1972, two-way trade amounted to $\$ 14$ billion, with a surplus for Japan of $\$ 4.9$ billion. By 1981, there was a trade deficit, on the American side of the ledger of $\$ 16$ billion. By 1982, total trade had climbed to $\$ 60$ billion, and the American deficit had amounted to $\$ 17$ billion. ${ }^{19}$

The relationship between the United States and Japan in the post World War II era, however, is a complex one. While many Americans railed against Japanese imports, the United States provided 80 percent of Japan's grain imports and 95 percent of its requirements for soybeans. Japan, in fact, was the leading customer for American farmers. Annually, American farmers supplied over $\$ 7$ billion worth of agricultural products to Japan. ${ }^{20}$

\footnotetext{
${ }^{17}$ John K. Emmerson and Harrison M. Holland, The Eagle and the Rising Sun: America and Japan in the Twentieth Century, ed. Miriam Miller, The Portable Stanford (Stanford, California: Stanford Alumni Association, 1987), 6-9. These issues would continue to imperil the Japanese-American relationship through the mid-1980s.

${ }^{18}$ Ibid., 61-62.

${ }^{19}$ Ibid., 67-68.

${ }^{20}$ Ibid., 26.
} 
This complicated relationship extended to Japanese investments in the U.S. where Japanese investment had generally been welcomed. However, starting in the late 1970s and early 1980s, there were the beginning signs of what some Japanese called "investment frictions." Even the appearance that Japan was freely buying up American properties with profits from an unfair trade system — whether true or not — could create an explosive political situation. However, even under these circumstances, Japanese investors could count on significant political allies in the United States. Besides businesses, their American partners included local populations and mayors, governors and members of Congress who saw jobs being created and economic activity being stimulated in their districts. State governments, in fact, competed with each other for Japanese investments. $^{21}$

**United Kingdom**

The United Kingdom never presented an economic threat to the United States (during the periods under consideration in this chapter). Therefore, we will now turn to various military threats to American supremacy.

\section{Military Threats}

**Russia/Soviet Union**

Despite the fact that Russia was rising relative to the United States during the American Civil War, most Union supporters viewed Russia favorably. They mistakenly believed that the tsar had intervened on the Union's side when the Russian fleet had entered New York harbor. ${ }^{22}$

\footnotetext{
${ }^{21}$ Ibid., 111-15.

${ }^{22}$ In reality, the Russians were simply looking for a place to hide from the British and French.
} 
Furthermore, Alexander II had endeared himself to Northern antislavery leaders when he freed the serfs in $1861 .^{23}$

This atmosphere of goodwill helped pave the way to the purchase of Alaska in 1867. A deal to buy Alaska from Russia had been in the works for decades since the Russians had long understood, at least since the 1830s, that they had lost control of Alaska's trade and even its food supply to New England traders who had been exploiting the region for decades. Nor, the Russians reasoned, could the territory be defended against a British attack from neighboring Canada, or against the Americans should they choose to settle in the territory. In the face of this no-win-situation, officials around Tsar Nicholas I wanted to divest Russia of Alaska. By the mid1850s, the tsar was ready to sell, but the American Civil War precluded any transaction. The afterglow of Russia's perceived support during the Civil War helped warm the political atmosphere. This, in turn, allowed Secretary of State William H. Seward to sign the treaty to purchase the territory. ${ }^{24}$ The sale of Alaska was significant because, by selling the territory to the U.S., Russia essentially abandoned the Western Hemisphere. By doing so, and for the next three decades, Russia posed little danger to perceived American interests. ${ }^{25}$

The goodwill between the two countries began to evaporate, however, even before the ink was dry on the Alaska purchase treaty. Starting in the 1860s, Alexander II began enforcing old anti-Semitic regulations. Tsarist authorities often did not bother to distinguish between Russian Jews and American Jews, abusing and sometimes arresting American Jews. In the late 1860s, and for the next three decades, this issue (and other human rights issues) came to

\footnotetext{
${ }^{23}$ Kagan, Dangerous Nation: America's Place in the World from Its Earliest Days to the Dawn of the Twentieth Century, 286.

${ }^{24}$ LaFeber, The American Search for Opportunity, 1865 - 1913, 12-14.

${ }^{25}$ Kagan, Dangerous Nation: America's Place in the World from Its Earliest Days to the Dawn of the Twentieth Century, 286.
} 
dominate Russian-American relations as many Americans came to despise the Russian government. $^{26}$

\section{Before the Cold War $^{27}$}

During the 1920s and up until 1933, the official policy of the United States government regarding the Soviet Union was "nonrecognition." This policy allowed the United States to make clear its dislike for what was happening in the Soviet Union without actually doing anything about it. While American officials would welcome the overthrow of Bolshevism, the American government was not prepared to take active measures—-beyond denying normal diplomatic relations - to bring that event about. Instead the government would rely upon the effects of isolation and the passage of time to produce the desired results. ${ }^{28}$

This policy ultimately backfired during the 1920s. By the mid 1920s, most of the world's nations had established diplomatic ties with Moscow. The Republican administrations of the 1920s also inadvertently helped to stabilize the Soviet regime through the Republican commitment to the ideals of limited government and free enterprise. According to these principles, the government had no authority to force private American individuals and

\footnotetext{
${ }^{26}$ Ibid., 286-87.

${ }^{27}$ Historian John Lewis Gaddis suggests that Woodrow Wilson's administration came closest to seeking the overthrow of the Soviet government as a deliberate objective. Wilson refused to extend diplomatic recognition to the new Soviet regime, he initiated an elaborate ideological campaign against it, and in the summer of 1918 actually authorized the use of American military forces - alongside that of its wartime allies - in Siberia and North Russia. See Gaddis, The United States and the End of the Cold War: Implications, Reconsiderations, Provocations, 20. Unfortunately for this study, these actions do not qualify as preventive action because they did not occur at a time when Russia was in relative ascendance vis-à-vis the U.S. Therefore, we cannot include these interventions in our study of preventive action. This also suggests a problem with my overall concept of preventive action. By limiting this study to periods only in which the dominant state is declining relative to the challenger, I might be missing important cases. This is something that I will have to examine in further studies of this topic.

${ }^{28}$ Ibid., 21-22.
} 
corporations into compliance with official policy. Therefore, American trade, investment, and famine relief, played a major role in stabilizing the new Soviet government. ${ }^{29}$

American diplomatic recognition for the Soviet regime finally came in $1933 .{ }^{30}$ Goodwill from the recognition, however, had largely dissipated by 1939. The Nazi-Soviet pact and the invasion of Finland caused whatever amity was left to disappear altogether. Still, President Franklin D. Roosevelt took the consistent position that Germany posed a greater threat to world order than did the Soviet Union. He resisted pressures to break diplomatic relations with Moscow following the pact with Germany and the attack on Finland. He shared intelligence with Stalin pointing to the likelihood of a German attack; and when that attack finally came, in June 1941, he immediately embraced the Russians as allies and within months made them eligible for Lend Lease. As Gaddis points out, "These were not the actions of a nation determined to exploit the vulnerabilities of another."31

Gaddis also suggests, "There is simply no evidence that the Roosevelt administration at any point contemplated taking advantage of what in retrospect was the most obvious opportunity since 1917 to eliminate the Soviet regime: alignment, whether openly or surreptitiously, with the geopolitical objectives of Adolf Hitler." While it is true that the United States was content to allow the Red Army to bear the main burden of ground fighting in Europe, it is not clear at all

\footnotetext{
${ }^{29}$ Ibid., 22.

${ }^{30}$ Akira Iriye, The Globalizing of America, 1913 - 1945, ed. Warren I. Cohen, vol. III, The Cambridge History of American Foreign Relations (New York: Cambridge University Press, 1993), 146. Iriye suggests that recognition was extended to the Soviet Union in large part to "please farmers, industrialist, and traders who were keen on expanding the Soviet markets." Gaddis meanwhile argues, "The strongest justification, in Roosevelt's mind, for normalizing relations with Moscow was the need to counter the rise of potentially aggressive regimes in Berlin and Tokyo. Roosevelt's conviction that Germany and Japan posed greater threats to American interests than did the Russians, and that, despite differences on other points, Moscow and Washington had a common interest in opposing those aggressors." See Gaddis, The United States and the End of the Cold War: Implications, Reconsiderations, Provocations, 35-36.

${ }^{31}$ Gaddis, The United States and the End of the Cold War: Implications, Reconsiderations, Provocations, 22.
} 
that the United States and Great Britain could have created a successful second front much earlier than they did. ${ }^{32}$

\section{The Cold War}

At the end of the Second World War, the Soviet Union was a crippled giant. It was in no condition to engage in any kind of protracted economic or military competition with its American rival. The United States, on the other hand, was at the height of its strength. It had suffered relatively few casualties and little civilian dislocation. Its industrial capacity was actually twice what it had been before the war. Perhaps most importantly, it possessed a monopoly over atomic weapons and the means to deliver them. ${ }^{33}$

While the United States government at no point committed itself to overthrowing the Soviet regime, after 1945 it did take the lead in containing the expansion of Moscow's influence in the postwar world. ${ }^{34}$ After the death of President Roosevelt, President Harry S Truman tilted to the side of the hard-liners in his government almost immediately after assuming the presidency. Many of the hard-liners stayed on as the new president's chief policy advisers, while former FDR intimates began to leave. The hardliners offered clear-cut advice that was consistent with the new president's general outlook. ${ }^{35}$ The new president had a dislike for communism and

\footnotetext{
${ }^{32}$ Ibid., 22-23. Some Soviet scholars suggested that this was a deliberate attempt to bleed the Soviet Union dry and perhaps even destroy Stalin's regime. Gaddis argues that there is simply no evidence of this.

${ }^{33}$ Ibid., 23.

${ }^{34}$ Ibid., 26.

${ }^{35}$ Michael H. Hunt, Crises in U.S. Foreign Policy (New Haven and London: Yale University Press, 1996), 119. There has been much speculation as to whether Truman used the atomic bombings of Hiroshima and Nagasaki as a demonstration of American military and technological prowess in order to frighten the Soviets into submission and to persuade them not to be too aggressive in Asia or Europe. Though there was real fear on the part of Americans that communism was on the move and would spread throughout the globe, the evidence suggesting that Truman used the atomic bombings of the Japanese cities as a tool to coerce the Soviets is not convincing. Truman's primary motivation was to end the war as quickly as possible with as few American casualties as possible and before the Soviet Union could occupy large areas of South East Asia. See also Peter Lowe, The Origins of the Korean War, ed. Harry Hearder, Origins of Modern Wars (New York: Longman, 1986), 13.
} 
was more critical of the Soviet Union than Roosevelt had been. ${ }^{36}$ Truman also hoped to demonstrate his toughness and decisiveness as a policymaker.

However, Truman also understood the importance of the wartime alliance. ${ }^{37}$ As a result, his get-tough attitude did not immediately translate into a clear shift in policy. ${ }^{38}$ Instead, there was a gradual change in tone toward the Soviets. This was, in part, due to a changing view about the role the U.S. should play in Korea after the war. ${ }^{39}$ Despite these new concerns about the Soviet Union, there was never any real attempt to engage them through militarized preventive action.

Not everyone in the Truman administration agreed that the United States should be taking a harder line with the Soviets. Henry Wallace, Truman's Secretary of Commerce, delivered a speech in September 1946 in which he argued that containment was not the appropriate approach to take regarding the Soviet Union. The president soon fired him. ${ }^{40}$

By 1946 and especially in 1947, the ascendant attitude in Washington found expression in a general policy of containment. The new policy was announced by Truman in March 1947 along with a request to Congress for support for embattled Greece and Turkey. The president took the occasion to articulate the fundamental principle behind the containment policy: the United States would support any free people threatened by communist aggression or subversion. In June 1947, Secretary of State George Marshall proposed a program of economic aid to ensure stability in the vital western European sector of the containment line. The next month, in a widely read essay, Director of the State Department's policy-planning staff, George F. Kennan

\footnotetext{
${ }^{36}$ Lowe, The Origins of the Korean War, 11-12.

${ }^{37}$ Ibid.

${ }^{38}$ Hunt, Crises in U.S. Foreign Policy, 119.

${ }^{39}$ Lowe, The Origins of the Korean War, 11-12.

${ }^{40}$ Hunt, Crises in U.S. Foreign Policy, 121.
} 
(disguised as "X"), published an article in Foreign Affairs in which he laid out the strategic and moral implications of the Truman administration's new course. ${ }^{41}$

Kennan argued that the task of American diplomacy should be to ensure that Moscow's attempts to widen its influence were unsuccessful, and to persuade Soviet leaders to moderate their hostility toward the outside world. In an attempt to accomplish these goals, Kennan wanted to build countervailing centers of power along the periphery of the Soviet Union, through mechanisms like the Marshall Plan. He also hoped that these countervailing centers of power would erode Moscow's control over its own satellites. He believed that given such a situation, Soviet leaders would be forced to moderate their suspicion of the outside world. ${ }^{42}$

Despite the increasingly belligerent tone coming from Washington, Stalin continued to remain hopeful through the first half of 1947 that the Soviet Union and the United States would be able to remain friendly in the post war environment. When Truman stated his doctrine, drawing an ideological line across the world, Stalin responded with a cool reaffirmation of the possibilities of cooperation. Nor did Stalin approve of the leftist resistance in Greece. In fact, as Hunt notes, he called on Yugoslavia, Albania, and Bulgaria to terminate their support of the movement. Moreover, Stalin did not immediately reject the Marshall Plan. Instead, he sent a delegation led by Foreign Minister Vyacheslav Molotov to Paris to explore the intentions behind the plan. ${ }^{43}$

When Molotov reported to Moscow, however, Stalin had to conclude finally that the United States was trying to use its economic power to tighten its grip on Western Europe and to dislodge the Soviet Union from its advanced position in Eastern Europe. Meanwhile, Soviet intelligence in London had sent word of Anglo-American consultations over how best to direct

\footnotetext{
${ }^{41}$ Ibid., 120-21.

${ }^{42}$ Gaddis, The United States and the End of the Cold War: Implications, Reconsiderations, Provocations, 28.

${ }^{43}$ Hunt, Crises in U.S. Foreign Policy, 124.
} 
the Marshall Plan against Soviet interests. At the same time, Molotov reported from his preliminary soundings in Paris that Britain and France were "now in dire straits," so that only submission to U.S. interference would enable them "to overcome their economic difficulties." Stalin decided to withdraw his delegation from the Paris meetings and forbade participation in the Marshall Plan by the eastern Europeans. ${ }^{44}$

As relations between the two countries began to cool, there was talk about initiating a preventive war against the Soviet Union, though few people took it seriously. ${ }^{45}$ However, there was a real question regarding how much military strength would be necessary to discourage a Soviet attack against the West. The United States wanted to have enough military power to deter the Soviet Union, but not so much that the Soviet Union was provoked. Kennan was convinced that the Russians had nothing to gain by starting a war. The Truman administration in 1947 and 1948, accepting this assessment and accepting the calculated risk that the Russians would not attack, concentrated on economic rather than military instruments of containment. However, provocations in Europe such as the coup in Czechoslovakia and the blockade of Berlin set off calls from Europeans themselves for American military guarantees. The Truman administration would ultimately respond by creating the North Atlantic Treaty Organization (NATO). ${ }^{46}$

The year1948 proved to be a watershed year in American-Soviet relations. In June, Stalin - in an attempt to disrupt the Anglo-American-French effort to unite their zones of occupation in Germany - placed a blockade on Berlin. Once it was clear that the blockade had failed, Stalin abandoned crude pressure and turned to diplomacy to achieve his foreign policy goals. As the United States moved toward the creation of NATO and toward West German

\footnotetext{
${ }^{44}$ Ibid.

${ }^{45}$ I analyze this in some depth later in the chapter.

${ }^{46}$ Gaddis, The United States and the End of the Cold War: Implications, Reconsiderations, Provocations, 52.
} 
membership in that military alliance, the Soviet leader proposed a united but demilitarized Germany. Washington was no longer interested in Soviet plans regarding Germany. ${ }^{47}$

The lines of the Cold War solidified when the Soviets tested their first nuclear weapon in 1949. It was also in 1949 that Communist forces achieved victory in China over U.S.-backed Nationalist forces. Despite this seemingly good fortune for the communist bloc, Stalin's worst fears were realized with the Creation of NATO in 1949, and the integration of West Germany into that military alliance. From the Soviet perspective, they now faced a capitalist line of encirclement stretching from Turkey to Norway. It was becoming increasingly clear that Western Europe was lost. In order to counter the new American policy of containment, Stalin began to look elsewhere for revolutionary allies, especially among national-liberation movements. Then, in 1950, American policymakers were shaken by the conclusion of a Sino-Soviet alliance. ${ }^{48}$ Policymakers had also been dazed by the development of the Soviet atomic bomb. This event opened the possibility of nuclear retaliation against the United States or its allies. It also set off a debate about whether the United States should respond by building a "super" or hydrogen bomb. Opponents of the H-bomb questioned whether the new weapon would add any measure of security not already provided by atomic bombs. They also wondered whether it would irreparably damage prospects for the eventual control of atomic weapons and whether it would provoke the Russians into developing H-bombs of their own. Furthermore, they questioned the wisdom of nuclear weapons as the principal deterrent to Soviet aggression in the first place. Proponents of the H-bomb argued that whatever the military value of the new weapon, it was necessary to build it because the Russians surely would. ${ }^{49}$

\footnotetext{
${ }^{47}$ Hunt, Crises in U.S. Foreign Policy, 125-26.

${ }^{48}$ Ibid., 126-27.

${ }^{49}$ Gaddis, The United States and the End of the Cold War: Implications, Reconsiderations, Provocations, 52-53.
} 
A related issue to the ongoing discussion about the H-bomb was the development of a new national security strategy in 1950 . In response to these and other developments, the National Security Council put forward a fresh appraisal of the global situation. This report, NSC-68, offered a stark, even cataclysmic picture of ideological struggle between the American-led West and the Soviet-dominated East. NSC-68 concluded with proposals for a major increase in the defense budget. Truman immediately approved the general outlines of NSC-68 but asked for more information on the costs of the programs recommended in its conclusion. With the outbreak of war in Korea, however, Truman fully embraced NSC-68 and authorized a tripling of defense spending. ${ }^{50}$

Like Kennan, the authors of NSC-68 foresaw the possibility of exploiting potential cracks and weaknesses within the international Communist movement. The assumptions and goals of containment suggested that though the Soviet Union held an expansionist ideology, it was up to the United States to maintain the balance of power. Furthermore, containment of the Soviet Union could be accomplished without war between the two powers, but if war should occur between the U.S. and a Soviet proxy, the war could be kept carefully limited. The policy of containment also suggested that while internal change within the Soviet Union itself was not a prerequisite for the success of containment, the success of containment might bring about internal change. Finally, if containment was successful in bringing about internal changes to the Soviet Union, the Soviet Union might then be assimilated into the established international order. Containment promised no immediate results and no one could predict how long it might take. It depended upon the ability of Soviet leaders to free themselves from their own self-generated illusions. 51

\footnotetext{
${ }^{50}$ Hunt, Crises in U.S. Foreign Policy, 126.

${ }^{51}$ Gaddis, The United States and the End of the Cold War: Implications, Reconsiderations, Provocations, 28-30.
} 


\section{$\underline{\text { Korea as an Early Theater }}$}

Containment started to manifest itself even before the end of the Second World War. General Marshall and his colleagues in the Joint Chiefs of Staff believed the U.S. should occupy at least part of Korea in order to increase American power in the postwar balance between the U.S. and the Soviet Union in the Far East. Still, it was only after the atomic bombing of Nagasaki on 9 August 1945 that the U.S. planning for the occupation of Korea began in earnest. While the U.S. did not want to see the Soviet Union take control of the entire peninsula, there was a lack of commitment from Washington to support a government in the south. In essence, Korea was not important enough to warrant a deep commitment, but was too important to allow it to fall to the communists. Because of this American desire to reduce its presence in Korea, and still minimize the risk of the entire peninsula becoming communist in the short term, the UN became heavily involved in Korean affairs. The priority for the United States was clearly the occupation of Japan, and preventing the Soviets from having any role in its occupation. The Soviets ultimately agreed to the $38^{\text {th }}$ parallel as the demarcation line in Korea. ${ }^{52}$

Despite the fact that the U.S. government at first did not see Korea as the cornerstone of the policy of containment, Korea was important to Truman for two main reasons. First, he did not want to open himself up to accusations of "losing" another country to communism. Second, he viewed a communist Korean peninsula as a threat to Japan, which was seen as a key element of American strategy in the Far East. ${ }^{53}$

\footnotetext{
${ }^{52}$ Lowe, The Origins of the Korean War, $\mathrm{x}-43$.

${ }^{53}$ Ibid., xi.
} 


\section{$\underline{\text { Post Korea Cold War }}$}

Despite the increasing competition between the East and West in the aftermath of the Korean War, by the mid-1950s President Dwight D. Eisenhower acknowledged that nuclear war with the Soviet Union was unwinnable by either side. About that same time, Moscow was also ready to concede that there could be no winner in a nuclear war with the West. ${ }^{54}$ Instead of an actual war with the Soviet Union, Eisenhower and his advisers foresaw a long-term competitive relationship with the Soviet Union. This conclusion was based on two developments that manifested themselves in the late 1940s and early 1950s. First, Moscow's progress in developing nuclear weapons and the means to deliver them meant that war could destroy the United States itself. Because of this fact, Eisenhower quietly ruled out direct military confrontation between the two superpowers. Second, Eisenhower believed that the strategy of building centers of resistance to the Russians in all parts of the world threatened by Soviet expansion ran the risk of bankrupting the United States and ultimately undermining its way of life. The president thus neither expected nor sought a quick end to Soviet-American competition. Instead, he concentrated on finding ways to allow the U.S. to sustain that rivalry over an extended period, and to do so while reducing the chances of war between the superpowers. ${ }^{55}$

President Eisenhower and Secretary of State John Foster Dulles did not see the SinoSoviet bloc as a unified monolith. Dulles, in fact, sought to implement strategies for driving a wedge between the Soviet Union and China. The public, however, knew nothing of this. Official rhetoric continued, well into the Kennedy and Johnson administrations, to portray a monolithic communist threat to the "free world." Gaddis suggests that this was done "for fear that the

\footnotetext{
${ }^{54}$ Hunt, Crises in U.S. Foreign Policy, 128.

${ }^{55}$ Gaddis, The United States and the End of the Cold War: Implications, Reconsiderations, Provocations, 31-32.
} 
domestic consensus in support of containment might crumble if the threat came to seem less awesome than in fact it appeared to be.",56

Eisenhower's preferred strategy was the so-called "New Look." This approach relied heavily upon the prospect of nuclear retaliation to deter Soviet expansionism while at the same time conserving limited American resources. Official strategists came to emphasize deterrence through the accumulation of overwhelming and instantly deliverable force. The strategy, however, did not depend wholly upon the deterrent effect of nuclear weapons. Eisenhower also endorsed negotiations as a way of reducing the danger of war while lowering the costs of confrontation. Gaddis argues, "Since surrender was unthinkable, military victory impossible, and the cost of long-term containment unacceptable," it seemed reasonable to find ways in which the Soviet-American rivalry — which was seen as inevitable — could be carried on within a mutually acceptable framework. Through such a framework, the two sides would be able to coexist indefinitely. This policy of competitive coexistence was continued by the Kennedy and Johnson administrations. ${ }^{57}$

John F. Kennedy had made much of the issue of a "missile gap" between the Soviet Union and the United States during the 1960 campaign. Even after he learned what Eisenhower had known all along - that the Soviet threat had been grossly overrated-Kennedy continued to carry out a massive missile-building program. This buildup probably set off the actual Soviet building program that would bring the Russians to the point of parity with the United States in missile launchers by the end of the decade. ${ }^{58}$

By the time President Lyndon Johnson left office, the conditions of competition had dramatically changed, and not to the advantage of the United States. The U.S.'s military exploits

\footnotetext{
${ }^{56}$ Ibid., 55-56.

${ }^{57}$ Ibid., 32-57.

${ }^{58}$ Ibid., 56.
} 
in Southeast Asia had severely weakened its standing, both at home and in the world at large. In the meantime, the Soviet Union had used the opportunity to strengthen its own military position, and with somewhat less success, to widen its influence in the rest of the world. Still, no one in Washington had explicitly repudiated the goal of competitive coexistence first articulated by President Eisenhower. ${ }^{59}$

The incoming Nixon administration, however, saw the Kennedy-Johnson strategy as a failure that had allowed the Soviet Union to approach military parity with the United States. The new administration was determined to reverse this trend. However, Nixon's critics argued that the new administration was simply accommodating itself to the unfavorable reality. Nixon's strategy, "cooperative coexistence" added yet another chapter to the strategy of containment. ${ }^{60}$

**Prussia/Germany**

Americans - at least Northerners, Republicans, and the U.S. government they controlled - supported Bismarck's Germany for a brief time during and just after the FrancoPrussian War of 1870-71. Prussia's pro-Union leanings during the American Civil War and German immigrants - an ethnic population that outnumbered French immigrants fifteen to onehad contributed to the northern cause and was also a crucial Republican voting bloc in several states. ${ }^{61}$ It also helped that Germany's opponent was France, a country that many northerners despised because of France's pro-southern sympathies during the U.S. Civil War and its imperial

\footnotetext{
${ }^{59}$ Ibid., 34-35.

${ }^{60}$ Ibid. Nixon's strategy of "cooperative coexistence" in the 1970s falls outside the scope of this study since by 1970 the Soviet Union was no longer a challenger to a superior United States, but was in fact dominant over the United States.

${ }^{61}$ Kagan, Dangerous Nation: America's Place in the World from Its Earliest Days to the Dawn of the Twentieth Century, 290-91.
} 
pretensions manifested in its attempt to implant a European monarch in Mexico. ${ }^{62}$ Furthermore, many Americans also convinced themselves that Bismarck's newly unified Germany would be a beacon of liberalism in Europe, while Napoleon III's France was seen as the exemplar of imperial despotism. ${ }^{63}$

Unfortunately for German-American relations, the high expectations many Americans held for a liberal Germany were severely disappointed over the coming decades. The reality of conservative rule under Bismarck and the Kaiser gradually dismantled the mistaken image of a liberal constitutional government in Germany. Trade battles between the two countries in the 1880s did not help matters, and by the 1890s many Americans hated and feared Germany as much as they hated and feared Russia. Americans tended to view both of these nations as somehow backward, hostile to progress, despotic, and therefore aggressive. ${ }^{64}$

\section{The Crisis over Samoa}

American perceptions of Germany as a backward, hostile, and aggressive power shaped American strategic judgment and provided an ideological backdrop for the confrontation between the United States and Germany over the tiny islands of Samoa in the 1880s. Given this ideological environment, it should not be surprising that Americans would react strongly to Germany's attempts to gain a foothold in the South Pacific. ${ }^{65}$

The Samoan islands stood across the path of transpacific travel and through much of the nineteenth century had been a port of call for American whalers. The tribes and foreign

\footnotetext{
${ }^{62}$ Bradford Perkins, The Creation of a Republican Empire, 1776-1865, ed. Waren I. Cohen, IV vols., vol. I, The Cambridge History of American Foreign Relations (New York: Cambridge University Press, 1995), 204.

${ }^{63}$ Kagan, Dangerous Nation: America's Place in the World from Its Earliest Days to the Dawn of the Twentieth Century, 290-91.

${ }^{64}$ Ibid., 292.

${ }^{65}$ Ibid.
} 
settlers who lived there had often engaged in internecine struggles. The various factions often looked to outside powers for help and offered their harbors as inducements. ${ }^{66}$ The Samoans, fearing British and German attention, were attempting to pit foreigner against foreigner.

Land speculators and American firms, arrived first to Samoa hoping the islands would serve as a strategic base that would help open trade to Asia and relieve the growing glut of U.S. goods. However, it was the 1872 treaty, signed by Navy Commander Richard W. Meade without advance authorization from the U.S. government, that for the first time truly involved the United States government in Samoan affairs. Mead was primarily interested in the fine, protected harbor of Pago Pago, for which he received a lease in return for a protectorate. The Senate accepted the harbor but rejected the responsibility of a protectorate. In a modified pact, the U.S. promised that it would mediate in any conflict between Samoa and foreign powers in exchange for rights to a naval station at Pago Pago. This proved more acceptable to the Senate. Later, the Samoans made similar agreements with both Germany and Great Britain. Though the Samoans attempted to play the foreigners off each other, in reality the U.S., British, and German consuls worked out a tripartite agreement for joint protection of the islands. The Americans were also encouraged by the appointment of the pro-American King Malietoa Laupepain. The tripartite arrangement existed for the next eight years, although not without growing conflict between U.S. and German claims. ${ }^{67}$

By the mid-1880s, German commercial interests were expanding in the South Pacific. As this expansion occurred, Germany began to demand greater control over the Samoan islands. In 1885, Secretary of State Thomas F. Bayard warned Berlin that he would "not allow any

\footnotetext{
${ }^{66}$ Ibid., 335-36.

${ }^{67}$ Ibid.
} 
one power to have a commercial preference." Powerful German business interests also began to support a rebel group who, if successful, vowed to overthrow King Malietoa Laupepain and install a more German-friendly king. ${ }^{68}$

Bismarck tried to reassure the Americans that German moves were not hostile to American interests. He announced, "We have no interest whatsoever in gaining a foothold anywhere in the Americas, and we acknowledge unequivocally that, with regard to the entire continent, the predominant influence of the United States is founded in the nature of things and corresponds most closely with our own interests." Such pronouncements from the Chancellor did little to ease American concerns. Neither President Grover Cleveland nor Secretary of State Bayard was prepared to back down in the face of what they regarded as German bullying. They wanted to uphold the independence and autonomy of the Samoan people free from "foreign interference.” In so doing, they hoped to prevent Germany from dominating Samoa. ${ }^{69}$

By 1887, the Germans, having grown impatient with the standoff with the United States over Samoa, dispatched four warships to the islands. The Germans demanded indemnities and apologies from King Malietoa for various alleged offenses. The Germans landed seven hundred marines, ravaged several villages, seized Malietoa, and recognized another chieftain as king. American officials were outraged by the German actions. The Samoan government appealed to the United States government for help. ${ }^{70}$

The three powers met at Washington in 1887 to sort out the imperial claims. Bayard beat down German plans for de facto control with the argument that in U.S. eyes, Samoan ports were a vital link in the system that connected the U.S. railroad network to Asia. Nothing came out of the conference, and in 1888 Germany moved more

\footnotetext{
${ }^{68}$ Ibid.

${ }^{69}$ Ibid., 302-37.

${ }^{70}$ Ibid., 338.
} 
directly to seize power. American opinion flared, led by business groups such as the San Francisco Chamber of Commerce, which ominously warned that if Samoa fell to the Germans, Hawaii would be next. As Washington prepared to respond, the Iron Chancellor wondered aloud why Americans were so concerned about these "remote, inconsiderable islands." In a note to Bayard, Second Assistant Secretary of State Alvey A. Adee outlined the geopolitics of a rising Pacific empire:

They may be remote and inconsiderable for Germany, but to us they are proximate and considerable, for in the hands of a naval Power they threaten our Pacific flank, and indeed they threaten all the Pacific Coast of South America too, and Hawaii besides. Samoa offsets Pearl Harbor, and Bismarck so intends it.

President Grover Cleveland adopted Adee's ideas and sent a ringing message to Congress upholding U.S. rights. Congress began to consider military appropriations.

While the press of both the Republican and Democratic parties condemned Germany's mistreatment of the islanders, Bayard was determined to avoid war with Germany. He assured the Samoans and the American people that he would do what he could "to secure a measure of justice and fair treatment to these innocent and unhappy islanders," but there was little he could do "without placing in useless jeopardy the vaster interests of our own countrymen." He warned that war with Germany would be a terrible thing. His concerns were confirmed by a senior naval officer who reported, "If we go to war with Germany there is an extreme probability that the German fleet may threaten to shell New York.... We have practically nothing with which to drive the enemy away, and it would take a long time to build anything suitable for that purpose." Bayard also declared that the United States had "no policy of annexation or protectorate whatsoever in Samoa or anywhere else." However, he and 
other Americans saw Germany as a bully and felt both sympathy and responsibility for the Samoans. $^{71}$

The year 1888 was also an election year, and the president was feeling political pressure to do something about the Germans. Most Americans did not have strong opinions about Samoa, but when the Kaiser raised a challenge, many Americans wanted their government to respond vigorously and curb German adventurism in the South Pacific. President Cleveland, under pressure at home and angry at German behavior, dispatched three warships to Samoa to "protect American interests" in the ongoing fighting. By early 1889, the port of Apia was crowded with foreign warships: three American, three German, and one British. It was not difficult to imagine conflict erupting through miscalculation or misunderstanding. Bismarck called for a conference in Berlin, but before it could convene, the three nations' warships were struck by a mighty typhoon. Only the British vessel escaped to open water and survived. Fifty American and ninety German sailors were lost. The sheer magnitude of the tragedy temporarily overshadowed the international confrontation. Thanks to the diplomatic breathing room created by the typhoon, a settlement was reached later that year temporarily restoring tripartite cooperation in Samoa. The United States received its main demand, its own protectorate over Pago Pago harbor. ${ }^{72}$

The Run-up to the Second World War

The American reaction to German provocation in the early and mid-1930s was understated, to say the least. In 1933, Adolph Hitler denounced the Geneva disarmament conference and withdrew Germany from the League of Nations. Two years later Britain entered

\footnotetext{
${ }^{71}$ Ibid., 339-40.

${ }^{72}$ LaFeber, The American Search for Opportunity, 1865 - 1913, 90-91.
} 
into a naval agreement with Germany that allowed the German navy to grow to 35 percent of Britain's naval strength. This was a significant increase for Germany over the levels established at the end of the First World War. Then in 1936, German troops marched into the Rhineland and reoccupied an area that had been termed a demilitarized zone at the end of World War I. The powers, including the United States, did largely nothing. ${ }^{73}$

In November 1936, President Franklin Roosevelt took a minor step to prevent German influence from expanding into the Americas. In that month, Roosevelt travelled to Buenos Aires, Argentina where he headed a conference designed to create an atmosphere of cooperation between the American nations and prevent outside interference. Curbing German influence in the Western Hemisphere was clearly the aim. At this and subsequent meetings, the American nations agreed to consult with each other regarding threats to the hemisphere. Also because of this conference, cultural exchanges flourished between the American nations. ${ }^{74}$

Akira Iriye suggests that the United States gradually took steps, starting with the Buenos Aires conference, to begin reengaging in foreign affairs. Some of these attempts were abortive, such as Roosevelt's attempt to reach across the Atlantic to British Prime Minister Neville Chamberlain. Roosevelt had hoped to meet with Chamberlain to discuss cooperation in international affairs between the two nations, but nothing came of the invitation. In October 1937, Roosevelt made a speech in Chicago where he called for international cooperation to isolate or "quarantine" aggressive states. While not much attention was paid to the speech at the time, in retrospect it shows that Roosevelt's thinking regarding the actions of Japan and Germany had begun to change. Immediately after the speech, Under Secretary of State Sumner Welles proposed a world conference to clarify fundamental principles of international relations.

\footnotetext{
${ }^{73}$ Iriye, The Globalizing of America, 1913 - 1945, 145.

${ }^{74}$ Ibid., 154-55.
} 
Nothing came of this proposal, but both Roosevelt and Secretary of State Cordell Hull supported the League of Nations when it called for a conference to discuss the Sino-Japanese War. The conference was boycotted by Japan and Germany, and not much, other than a condemnation of Japanese actions, came of the conference. Still, it is another example that the U.S. was beginning to take a more active role on the international stage. ${ }^{75}$

In March 1938, Germany annexed Austria—in what it called the Anschluss-and began preparing "Mitteleuropa" for German hegemony. The United States responded to the Anschluss by announcing that it would step up its rearmament program. This rearmament would go beyond the "treaty limits" imposed by earlier naval disarmament agreements that had been nullified since $1936 .^{76}$

Between 26 September and 28 September 1938, Roosevelt sent an appeal to all parties involved to resolve the Sudetenland crisis - the German invasion of Czechoslovakiapeacefully. When the Munich conference seemed to settle this dispute, Roosevelt expressed his approval. U.S. involvement on the international stage was again seen in November 1938, in the wake of Kristallnacht (the night of broken glass) in which Jewish businesses and synagogues were destroyed, and Jews killed or jailed by the Nazis. President Roosevelt was outraged and withdrew Hugh Wilson, chargé d'affaires in Berlin. William Dodd, the U.S. ambassador to Germany, had already resigned in late 1937 in disgust at Nazi race policies. Hitler responded by withdrawing the German ambassador from Washington. Both posts would remain empty for the remainder of the prewar period. ${ }^{77}$

After September 1938, there were increasing calls for some kind of action against Hitler's Germany. His aggression in September 1938 was so obvious and so revolting that Senator

\footnotetext{
${ }^{75}$ Ibid., 157-58.

${ }^{76}$ Ibid., 151-60.

${ }^{77}$ Ibid., 160-61.
} 
George Norris of Nebraska, a veteran isolationist and the only surviving member of Congress who had voted against America's entry into the First World War, publicly stated that, faced by such a situation, he would be among those who "would consider a preventive war against the Fascist nations. ${ }^{, 78}$

Other measures were considered at the conference of American states held in December 1938. In Lima, Peru, the American nations issued a resolution decrying Nazi race doctrines. Closer consultative ties were also adopted. At about the same time, Roosevelt decided to start selling military aircraft to Britain and France for a possible war against Germany. ${ }^{79}$

At the beginning of 1939, at the behest of President Roosevelt, the United States embarked on a rearmament campaign unparalleled in American history during peacetime. Fifteen percent of government outlays were going to be for defense. For fiscal year 1940, this would amount to $\$ 1.3$ billion out of a total $\$ 9$ billion budget. Total defense spending was actually even more than this since Congress granted the president additional appropriations for defense. ${ }^{80}$

Further steps were being taken that would involve the United States much more in global affairs, even at the risk of becoming involved in the emerging conflict in Europe. In November 1939, after the outbreak of war in Europe, Congress revised the neutrality laws to allow belligerents to purchase American arms on a cash-and-carry basis. ${ }^{81}$ This policy was clearly aimed at helping supply the British with war materials since the British controlled the seas.

Even before the United States entered World War II, members of the American General Staff proposed that the U.S. should "take immediate steps to acquire British and French possessions in the Atlantic," so as to deny the Germans their use. Plans for American measures

\footnotetext{
${ }^{78}$ Alfred Vagts, Defense and Diplomacy: The Soldier and the Conduct of Foreign Relations (New York: King's Crown Press, 1956), 313-14.

${ }^{79}$ Iriye, The Globalizing of America, 1913 - 1945, 161.

${ }^{80}$ Ibid., 164.

${ }^{81}$ Ibid., 165.
} 
“"to protect such [possessions] from falling into the hands of Germany by surrender or cession" were worked out promptly. Concerns about German moves in South America prompted plans for the United States "to anticipate action by the preventive occupation of airfields and ports" in the region. $^{82}$

Vagts argues that the intent of the "policy of the Roosevelt Administration in the prePearl Harbor period...was clearly preventive.” In fact, he suggests that the U.S. entered both world wars in an attempt to prevent a German victory in Europe. It was imperative, however, that the U.S. government avoid all appearance of having preventive war intentions, since the long democratic tradition against the waging of preventive war obviously persisted. The Roosevelt administration's preventive intention was first concretely expressed, Vagts continues, by aiding the peoples who were resisting Hitler, so that they would not be "knocked out of the war one by one before our turn came and that we would [not] ultimately be left to face the onslaught alone." Modern conditions of warfare, Roosevelt warned, would not permit the United States to wait until it was physically attacked. ${ }^{83}$

**Japan**

When Japan began its steady rise in the 1860s, there was a consensus in the United States that Japan was a progressive force in Asia. It was seen as making a determined effort to copy Western ways and institutions and Americans admired the Japanese peoples' eagerness to adopt new ideas. In short, Americans believed that Japan was becoming more like America. At the same time, Americans also recognized that as a rising power destined to be a force in East Asia - where the United States also hoped someday to be an important player-Japanese and

\footnotetext{
${ }^{82}$ Vagts, Defense and Diplomacy: The Soldier and the Conduct of Foreign Relations, 322.

${ }^{83}$ Ibid., 266-323.
} 
American interests were likely to clash. Nonetheless, Americans rooted for Japan in the Sino-

Japanese War of 1894-95 because Japan was viewed as strong and progressive and China was seen as backward and pitiful. When Japan attacked and sank the Russian fleet at Port Arthur ten years later, Americans applauded again. ${ }^{84}$

\section{The Run-up to the Second World War}

In January 1930, Great Britain, the United States, and Japan held a naval disarmament conference in London where the three countries agreed to limitations on naval armaments. This would be the last agreement between the three countries for years. Even though the Japanese delegation to London accepted the limitations on Japanese naval armaments, Japanese naval leaders were not happy and argued that the civilian leadership had sold out to the British and Americans. This criticism of the civilian leadership helped weaken the Japanese government and made it vulnerable for a military takeover. ${ }^{85}$ Prime Minister Hamaguchi Osachi was assassinated shortly after accepting these naval limitations. ${ }^{86}$

The power of the military was enhanced when, in September 1931, the Japanese army stationed in Manchuria began a campaign against the Chinese that resulted in a nearly complete Japanese victory. The United States and other powers worked through the League of Nations to bring about a diplomatic resolution to the crisis, but this never really had any effect on the

\footnotetext{
${ }^{84}$ Kagan, Dangerous Nation: America's Place in the World from Its Earliest Days to the Dawn of the Twentieth Century, 293-94. Despite the feelings of goodwill towards Japan, some Americans began to feel a tinge of concern that Japan might turn out to be too powerful, too modern, and therefore a threat to American interests in the Pacific. These fears, however, were generally overwhelmed by the perception that Japan stood for progress and by the pervasive American conviction that progress was always in the interests of the United States. Unfortunately, once again, both the Sino-Japanese War and the sinking of the Russian fleet cannot be included in my formal analysis because they did not occur during years in which the United States was declining relative to Japan.

${ }^{85}$ Iriye, The Globalizing of America, 1913 - 1945, 122-23.

${ }^{86}$ Hunt, Crises in U.S. Foreign Policy, 61.
} 
actions in Manchuria, and Japan ultimately withdrew from the League of Nations. ${ }^{87}$ Henry L. Stimson, Herbert Hoover's secretary of state, argued that the United States had an obligation to uphold basic standards of decency and international law and should rally the support of the international community against the Japanese aggression. President Hoover, however, did not want to risk war and felt that his focus should be on the moribund American economy. ${ }^{88}$

As the Great Depression deepened during the 1930s, American foreign policy faltered. Americans were increasingly preoccupied by what was going on within their own country and wanted to focus on repairing the ills of the economy at home. They were less interested in what was happening abroad. Despite the U.S.'s new tendency to pay less attention to foreign affairs, Americans were not happy with the announcement in 1934 by the Japanese Foreign Ministry that the Japanese government would not look favorably on countries who chose to deal directly with China without consulting Japan first. In response to these Japanese moves, Roosevelt chose not to recognize the puppet state of Manchukuo, which the Japanese had set up in Manchuria. The Roosevelt administration would not reward Japanese aggression, but neither would it take any significant action to roll the Japanese back. ${ }^{89}$

This sense of the U.S. abandoning its leadership position in the world was exemplified by the Neutrality Act of 1935 in which the U.S. Government outlawed the sales of arms to belligerents in a war. This went against the traditional American ideals of neutrality in which a neutral country could sell arms to all belligerents. Americans, by 1935, wanted to focus on developing the domestic economy, and they did not want to get involved in foreign conflicts. ${ }^{90}$

\footnotetext{
${ }^{87}$ Iriye, The Globalizing of America, 1913 - 1945, 124-27.

${ }^{88}$ Hunt, Crises in U.S. Foreign Policy, 62.

${ }^{89}$ Iriye, The Globalizing of America, 1913 - 1945, 128-44.

${ }^{90}$ Ibid., 128-40.
} 
When the London naval armament agreements expired in 1936, there was no new agreement reached between Japan, the U.S., and Great Britain. Japan began to build a powerful navy to first catch up to and then surpass the United States in the Pacific. Also of significance in 1936, Japan, Germany, and Italy signed the anti-Comintern pact in which each country secretly agreed to come to the aid of the others should any one of them become involved in a war with the Soviet Union. ${ }^{91}$

Another step towards global conflict came in the form of renewed fighting between China and Japan, which broke out in July 1937. Also, at the end of 1937, the Panay incident—in which Japanese military aircraft sank an American gunboat on the Yangtze - proved to be another step toward renewed American internationalism. The gunboat had been evacuating American personnel from Japanese occupied Nanking when it was attacked. The Japanese offered an immediate apology and paid an indemnity, but Roosevelt was clearly alarmed by the action. He sent Captain Royal Ingersoll—chief of the U.S. Navy's intelligence division - to London to open secret talks with his British counterpart about possible joint action against Japan should such provocation continue. These were the first of what would be ongoing talks regarding bilateral military cooperation between the two nations. ${ }^{92}$

Despite the rising tensions with Japan, the United States continued to sell armaments to the island nation. In 1938, American arms shipments to Japan amounted to \$9.1 million. Increasing public outcry over the Japanese aggression regarding China put mounting pressure on the U.S. government to halt these sales. In July 1938, the State Department announced a moral

\footnotetext{
${ }^{91}$ Ibid., 143-63.

${ }^{92}$ Ibid., 149-63.
} 
embargo of airplanes to Japan. This was not legally binding, but sent a message to Japan that they might not be able to rely on American suppliers of armaments in their war against China. ${ }^{93}$

In November 1938, after conquering much of China but still not being able to defeat completely the Chinese, the Japanese called for a "new order" in Asia based on Asian ideals and principles, not on Western concepts that had dominated the region for centuries. This clearly presented a challenge to the Western nations, including the United States. Secretary of State Cordell Hull immediately denounced the Japanese's "new order," arguing that Japan had no right to create a new order unilaterally. He stated that the United States would oppose Japanese unilateralism and would not recognize any modification in the regional status quo except through consultation and cooperation. ${ }^{94}$ Because of this and other provocations, the U.S. began rebuilding the U.S. Navy in both the Atlantic and Pacific. ${ }^{95}$

To drive the point home, in December 1938 the United States issued a loan of \$25 million to the Chinese to use in any way they chose. In 1939, the United States withdrew from the treaty of commerce it had with Japan, creating a situation where Japanese shippers, merchants, and bankers were no longer protected by treaty rights, thus Japan was more at the mercy of American goodwill. ${ }^{96}$ It was becoming clear to both the Chinese and the Japanese where the U.S. stood in the Sino-Japanese War. ${ }^{97}$

By 1939, war had spread in China and anti-Japanese feeling was on the rise in the United States. When the U.S. government announced it was going to terminate the commercial treaty with Japan, the American public overwhelmingly approved. Joseph C. Grew, the American

\footnotetext{
${ }^{93}$ Ibid., 162-63.

${ }^{94}$ Ibid., 149-63.

${ }^{95}$ Hunt, Crises in U.S. Foreign Policy, 66-67.

${ }^{96}$ Ibid., 67. In 1940 and 1941, this goodwill would run out and the United States would ultimately embargo war material like iron, steel, and eventually even oil.

${ }^{97}$ Iriye, The Globalizing of America, 1913 - 1945, 163.
} 
ambassador in Japan from 1932 to 1941, was home on leave when the announcement was made, and he was astonished at the public support for a trade embargo. He warned the State Department and the public that a policy of sanctions could lead to war. ${ }^{98}$

\section{$\underline{\text { Post World War II }}$}

On 8 September 1951, the U.S. and Japan signed a peace treaty and endorsed a mutual security treaty that would guarantee Japan's security and provide for the stationing of American military forces in Japan. From this point onward, the United States assumed responsibility for the security of Japan, especially from nuclear attack. The treaty created a security environment in Japan of dependence on the United States. ${ }^{99}$ As the decades wore on, however, there would become increasing tensions between the two nations.

By the 1960s, Japan began to enjoy remarkable economic growth that would bring, within a few years, Japan to the position of third greatest economic power in the world. Prime Minister Ikeda Hayato embarked on his policy of the "low posture" (teishisei), meaning that Japan would concentrate on its economic development and avoid international quarrels. By 1962, the Gross National Product (GNP) was already three times that of the prewar period 1934$1936 . .^{100}$

The Japanese have used their constitution as a shield against remilitarization and as an avenue for the "low posture" of Japanese defense spending. Article 9 of the Japanese constitution categorically states that the Japanese people "forever renounce war as a sovereign right" as well as the "threat or use of force as a means of settling international disputes." Japanese leaders have interpreted this article to mean that Japan is prohibited from establishing military forces and from

\footnotetext{
${ }^{98}$ Emmerson and Holland, The Eagle and the Rising Sun: America and Japan in the Twentieth Century, 50.

${ }^{99}$ Ibid., 61-123.

${ }^{100}$ Ibid., 61-62.
} 
developing war potential. During the 1970s, they also instituted a policy of banning any sales of weapons or defense technology to any nation without exception. Many Americans regarded the Mutual Security Treaty and the long history of American-generated military aid and sales programs as justification for a relaxation of the ban in the case of the United States. The issue in Japan was contentious since there was a fear that any change in the interpretation of laws regarding security matters could open Pandora's Box leading to the remilitarization of Japan. Also of significance, by the early 1980s, the U.S. wanted Japan to build up its military, thus relieving some of the burden from the United States. Ultimately, Prime Minister Nakasone Yasuhiro yielded to American pressure - and his own concepts of a reasonable defense force for Japan - and agreed to the sale of Japanese weapon technology to the United States in January $1983 .^{101}$

**United Kingdom**

Great Britain and the United States often had strained relations during the eighteenth and nineteenth centuries, but by the twentieth century, most of the issues that divided the two countries had been resolved. The status of Canada had been settled and British ambitions in Latin America had been quelled. ${ }^{102}$ During the periods under investigation in this study, there was little or no military animosity between the United States and Britain.

The one minor exception to this might be the Suez Crisis of 1956, in which Gamal Abdul Nasser, the president of Egypt, nationalized the Suez Canal. For the British, the canal was a vital link between Western Europe and Persian Gulf oil. After attempting negotiation at the behest of the Americans, British Prime Minister Anthony Eden, with cooperation from the French and the

\footnotetext{
${ }^{101}$ Ibid., 71-121.

${ }^{102}$ Perkins, The Creation of a Republican Empire, 1776-1865, 205.
} 
Israelis, embarked on military action to prevent Nasser's nationalization of the canal. President Dwight D. Eisenhower was surprised by the invasion and he was furious. He stated, "How could we possibly support Britain and France if in doing so we lose the whole Arab world?"103 The United States went on to sponsor resolutions in the United Nations Security Council to end British, French, and Israeli military action. The U.S. did this, in part, to prevent Soviet intervention in the crisis. Under American pressure, the British, French, and Israelis withdrew their forces from Egypt. ${ }^{104}$

\footnotetext{
${ }^{103}$ John Lewis Gaddis, The Cold War: A New History (New York: The Penguin Press, 2005), 127-28.

${ }^{104}$ Warren I. Cohen, America in the Age of Soviet Power, 1945 - 1991, ed. Warren I. Cohen, vol. IV, The Cambridge History of American Foreign Relations (New York: Cambridge University Press, 1993), 109-14. I do not explore this in more detail because it does not appear to be preventive in nature.
} 


\section{$\underline{\text { Analysis }}$}

In this section, I assess the performance of the Domestic Politics Model of Prevention in predicting the outcome of American foreign policy during the periods under consideration.

Following the method of structured, focused comparison, each of the eleven questions posed in the previous chapters are answered, and then an overview of the model's performance is outlined for each question. The typology for this model appears in table 6.1 while the flowcharts for the individual cases appear in Appendix A.

Table 6.1: A Typology of Preventive Action

\section{Causal Mechanisms}

\begin{tabular}{|c|c|c|c|c|c|}
\hline & & $\begin{array}{l}\text { Systemic } \\
\text { Structure/ } \\
\text { Polarity }\end{array}$ & $\begin{array}{l}\text { Internal } \\
\text { Power } \\
\text { Constraints/ } \\
\text { Offense vs. } \\
\text { Defense }\end{array}$ & $\begin{array}{l}\text { Domestic } \\
\text { Political } \\
\text { Constraints/ } \\
\text { Pressures }\end{array}$ & $\begin{array}{l}\text { Ruler Belief } \\
\text { Systems/ } \\
\text { Perception of } \\
\text { Threats }\end{array}$ \\
\hline & $\begin{array}{l}\text { Acquiescence/ } \\
\text { Do Nothing }\end{array}$ & $\begin{array}{l}\text { Bipolar/ } \\
\text { Balanced } \\
\text { Multipolar }\end{array}$ & $\begin{array}{l}\text { Severe/ } \\
\text { Defensive } \\
\text { Strategy }\end{array}$ & $\begin{array}{l}\text { Severe Political } \\
\text { Constraints/ } \\
\text { Pressure }\end{array}$ & $\begin{array}{l}\text { Moderate - } \\
\text { Acquiescent/ } \\
\text { Low - Non- } \\
\text { Militarized }\end{array}$ \\
\hline$\vec{\Xi}$ & $\begin{array}{l}\text { Accommodation/ } \\
\text { Mix of Strategies/ } \\
\text { Carrot and Stick }\end{array}$ & $\begin{array}{l}\text { Bipolar/ } \\
\text { Balanced } \\
\text { Multipolar }\end{array}$ & $\begin{array}{l}\text { Moderate/ } \\
\text { Defensive- } \\
\text { Offensive } \\
\text { Strategy }\end{array}$ & $\begin{array}{l}\text { Moderate } \\
\text { Political } \\
\text { Constraints/ } \\
\text { Pressure }\end{array}$ & $\begin{array}{l}\text { Moderate - } \\
\text { Pragmatic/ } \\
\text { Moderate - } \\
\text { Non- } \\
\text { Militarized }\end{array}$ \\
\hline$\stackrel{\tilde{J}}{0}$ & $\begin{array}{l}\text { Initiate Sustained } \\
\text { Coercive/ } \\
\text { Confrontational } \\
\text { Diplomacy }\end{array}$ & $\begin{array}{l}\text { Bipolar/ } \\
\text { Unbalanced } \\
\text { Multipolar }\end{array}$ & $\begin{array}{l}\text { Moderate/ } \\
\text { Offensive- } \\
\text { Defensive } \\
\text { Strategy }\end{array}$ & $\begin{array}{l}\text { Moderate } \\
\text { Political } \\
\text { Constraints/ } \\
\text { Pressure }\end{array}$ & $\begin{array}{l}\text { Pragmatic - } \\
\text { Militant/ } \\
\text { Moderate - } \\
\text { Militarized }\end{array}$ \\
\hline & $\begin{array}{l}\text { Initiate } \\
\text { Militarized } \\
\text { Preventive Action }\end{array}$ & $\begin{array}{l}\text { Unbalanced } \\
\text { Multipolar }\end{array}$ & $\begin{array}{l}\text { Minimal/ } \\
\text { Offensive } \\
\text { Strategy }\end{array}$ & $\begin{array}{l}\text { Minimal Political } \\
\text { Constraints/ } \\
\text { Pressure }\end{array}$ & $\begin{array}{l}\text { Militant - } \\
\text { Radical/ } \\
\text { High - } \\
\text { Militarized }\end{array}$ \\
\hline
\end{tabular}




\section{1) To what extent is the internal power of the state constrained?}

Prior to its civil war, the United States was very constrained in its foreign policy relating to other major powers. It was extremely weak in terms of offensive military power. After the Civil War, the United States emerged more powerful and influential in world affairs, though still militarily weak vis-à-vis other major powers. Gaddis has argued that Americans were not always confident in their ability to wield their power wisely, and this military weakness might provide at least a part of the explanation for that timidity. This lack of confidence seems to dominate American foreign policy—at least in relation to other major powers - until the early to mid-1930s. It is really only broken by American successes and ultimate victory during the Second World War.

After the war, it is clear that the United States took on a real leadership role on the international scene. This leadership role and active foreign policy has continued to the present day. Obviously, in the post World War II era, particularly with the implementation of NSC-68 and other Cold War policy prescriptions, the internal power of the United States has been much less constrained than it was during previous periods. The United States has had considerable offensive military power, especially in terms of nuclear weapons, during this latter period. However, the strategy of the United States continued to be mostly defensive in the twentieth century. This section analyzes American foreign policy vis-à-vis the other powers in this study. 


\section{$\underline{\text { Russia/Soviet Union }}$}

Russia really removed itself as a threat to the United States in the nineteenth century with the sale of Alaska in 1867. There were, of course, other issues between the two countries - including the mistreatment of American Jews in Russia-but these issues never really translated into foreign policy. With the emergence of the Soviet Union, there was an ideological and then a military challenge to the United States. The U.S. reacted first with non-recognition and then eventually with cooperation during the Second World War. After the war, of course, the U.S. and the USSR slid into animosity towards each other.

After the war, there were minimal internal power constraints placed on the American leadership, at least in terms of pure military capability. Demobilization after the Second World War somewhat reduced American offensive potential, however. More significantly, we see other kinds of restraints placed on the American leadership. The policy of containment, by its very nature, tended to be a defensive doctrine. While some leaders and commentators advocated rolling back communism, the overall goal of containment came to be interpreted as holding the line until communism was forced to change or collapse from within.

It is clear that this defensive strategy placed constraints on internal power. It is difficult, however, to determine exactly where American internal power should be placed on the above typology. It is conceivable that these constraints were moderate since there was clearly capability, particularly in the early years of the Cold War, but the policy of containment acted as a constraint on the exercise of that capability. Given this, the typology would suggest a defensive-offensive or offensive-defensive 
strategy vis-à-vis the Soviet Union during this period. The typology, then, seems to do a good job of predicting actual American behavior in relation to the Soviet Union. During the Cold War, the United States used different strategies at different times to include coercion and incentives as well as confrontational diplomacy.

\section{Germany}

Despite serious internal constraints on power, the United States was able to force the tactical retreat of Bismarck from Latin America in the 1880s. Still, this was done more through diplomacy and cooperation with the Latin American countries than through threats or use of military force against Germany. In this case, Germany chose to back down rather than face the U.S. and its Latin American associates.

Such was not the case in the Samoan crisis. Here, the U.S and Germany nearly came to blows over the islands. There was, of course, a tripartite agreement between Germany, Britain, and the United States, but this ultimately broke down. This was followed by more negotiations, and then the deployment of warships by all three nations to the islands. Had it not been for the intervention of nature in the form of a typhoon that destroyed most of the warships harbored in Samoa, it is possible that militarized conflict could have erupted. This did not occur, however, and the three nations ultimately came to an agreement regarding the administration of the islands.

German-American relations were again strained with the increased militarization of Germany in the 1930s and then the outbreak of war in Europe. To counter the spread of German influence in Latin America, Franklin Roosevelt took a page out of the history books and developed closer relations between the United States and its 
Latin American neighbors. Roosevelt also moved in the direction of "quarantining" aggressive states.

With the Anschluss of 1938, the United States announced a rearmament program clearly aimed at Germany. Despite this new more confrontational stance, the United States did little during the Sudetenland crisis. After Kristallnacht, however, the U.S. did signal its displeasure by withdrawing Hugh Wilson from Berlin. At the end of 1938, Roosevelt took the step of selling military aircraft to Britain and France for a possible war against Germany. Finally, in early 1939, Roosevelt announced that the U.S. would embark on a massive military buildup in anticipation of the coming conflict. After the outbreak of war, the U.S. Congress revised the neutrality laws to help supply war materials to the British.

In terms of the above typology, we can see that, up until the eve of the Second World War, American leadership was severely constrained in terms of internal power-largely because of a relatively weak military and a defensive strategy. The typology suggests that in this case, the United States should have acted defensively and acquiesced in the face of German aggression. While the U.S. did act defensively for the most part, it did not acquiesce to German demands. It took action in Latin America (twice) to prevent German interests from developing there. It also confronted Bismarck's Germany with a show of military force in the Samoan islands. The United States' record seems weaker in the run-up to the Second World War, but even here it did not acquiesce in the face of German aggression, but instead took less direct measures to check German power. Therefore, the typology—which predicts 
acquiescence - does not seem to perform well, at least on this variable, in the case of Germany in the nineteenth and first half of the twentieth centuries.

$\underline{\text { Japan }}$

American relations with Japan prior to the Second World War are complex. When the U.S. "opened" Japan in the mid 1860s, its military actions were not of a preventive nature. On the contrary, the emergence of Japan on the international stage and favorable tariff policies would ultimately help the Japanese increase their power. At the same time, the majority of Americans saw the Japanese as becoming more liberal and modern and therefore less threatening to the United States.

In 1930, the Japanese, Americans, and British agreed on limitations of naval armaments. This was the last agreement between the three until after the end of the Second World War. American reaction to the Japanese invasion of Manchuria was weak. Its attempt to stop Japan by working through the League of Nations was ineffective, and the U.S. largely withdrew from the ongoing conflict in Asia with the passage of the Neutrality Act of 1935. While the United States would not recognize the Japanese puppet state of Manchukuo, and it denounced Japan's attempts to establish a "new order" in Asia; the American leadership failed to take any real action against Japan. It was only after the Panay incident in 1937 that Roosevelt began to coordinate with the British with an eye to eventual confrontation with Japan. By 1938, the U.S. was engaged in rebuilding its navy. Still, the U.S. continued to sell armaments to Japan through 1938. Finally, in 1939, the U.S. withdrew from its 
commerce treaty with Japan. Nonetheless, this was still a mild response to Japanese aggression in China.

In terms of the above typology, I would argue that the United States leadership was severely constrained in terms of internal power largely because of a relatively weak military and a defensive strategy for the period up until the eve of the Second World War. This defensive strategy did not lend itself to engaging in strong diplomatic or military coercion of Japan. In this case, the typology accurately predicts that the United States was likely to acquiesce or do nothing regarding Japan's aggression against China.

American-Japanese relations in the post World War II era are also complex, but the challenge from Japan — particularly in the 1970s and 1980s — was of an economic nature, not a military one. The military alliance made any use of American military power against Japan nearly impossible to fathom. Even economic coercion or retaliation against Japan for perceived injustices was difficult to implement. While "Japan-bashing" became a favorite activity for a brief time for some Americans, there seems to have been no real discussion of ending the special relationship between the two countries.

In this case, in contrast to minimal internal power constraints in terms of sheer military power, there were significant internal constraints due to treaties and the special relationship between the two countries. Aggressive action by the United States against Japan in the post World War II era has been largely unthinkable. Japan has been an important ally and trading partner. In this case, the measurement of offensive/defensive military strategy does not seem to apply. In fact, the American 
desire in the early 1980s to see Japan rebuild its military really runs counter to my preventive action theory. However, since Japan represented an economic challenge, not a military one, this may not be as bad for preventive action theory as it appears on first examination.

\section{$\underline{\text { United Kingdom }}$}

Similar to the situation with Japan in the post World War II environment, war between the United States and the United Kingdom during the entire twentieth century was highly unlikely. After 1930, their relationship actually became friendlier as Germany posed an increasing threat. After the war, Britain and the U.S. were closer than ever and faced the Soviet Union together. With the possible exception of the Suez Crisis, there has been little friction between the two nations. In the post Cold War environment, Britain has remained one of the United States' closest allies. The variable of internal power constraints does not seem applicable in this case.

\section{2) To what extent are pro-preventive action elements constrained?}

\section{$\underline{\text { Russia/Soviet Union }}$}

One of the big questions this study should answer is the following: So why did the United States not exploit the advantages it held in the years after the Second World War to eliminate, or at least neutralize, its most likely competitor in the postwar world? Prominent individuals — both within and outside the government — urged preventive war against the Soviet Union before it had had time to recover its 
strength. ${ }^{105}$ According to the Socialist Norman Thomas, in 1944-45 Washington already "buzzed with gossip that war with Russia was a paramount subject of discussion in the armed forces, with some officers, especially in the Navy, believing that since war is so likely we had better have it soon while we, rather than the Russians, are at the top of our strength."

Some Americans, eyeing the American monopoly of the atomic bomb, and frustrated over the spread of Moscow-centered communism, advocated using this ultimate weapon for fighting a preventive war against Russia. Robert M. Hutchins, Chancellor of the University of Chicago, told a Senate Committee, "We ought to start [a war] right now because we are in the best position to win it. The assumption that there is going to be a war would lead to the conclusion that we had better start the war this morning, because only this morning can we be sure of having supremacy in atomic bombs."107

There were, of course, opponents to this way of thinking. Vagts notes that in November 1945, ex-Ambassador to Moscow Joseph E. Davies denounced "a few militarists - not among the great war leaders - in this and other countries who advocate war with Russia and now rather than later." Davies called such talk "insanity" and equated it to "throwing dynamite around." 108

Similarly, Henry Wallace, relegated to the position of secretary of commerce, protested that "a school of military thinking" was advocating "a preventive war, an attack on Russia now before Russia has atomic bombs." To Wallace, such thoughts

\footnotetext{
${ }^{105}$ Gaddis, The United States and the End of the Cold War: Implications, Reconsiderations, Provocations, 23.

${ }^{106}$ Vagts, Defense and Diplomacy: The Soldier and the Conduct of Foreign Relations, 329.

${ }^{107}$ Ibid., 330.

${ }^{108}$ Ibid.
} 
seemed "not only immoral but stupid." Unfortunately for Wallace, since he gave no names of any advocates of preventive war, he made it easy for the Secretary of War and the Secretary of the Navy to deny that there was any basis for his accusations. They knew, they said, of no responsible Army or Navy officer "who has ever advocated or even suggested a policy or plan of attacking Russia. There is no such military thinking in the War and Navy Departments."109

Wallace may have had in mind statements like those of General H. H. Arnold. The general argued that there was only one defense against the atomic bomb, "hit it before it starts.... This country should capitalize on the atomic bomb, if necessary to assure world peace.” Another officer of the Air Force, Lt. General Ira C. Eaker, Deputy Commander of the Army Air Force, predicted, "The next war would be a short war of unparalleled destruction, that the first blows would be struck through the air, and that to prevent destruction of this country in event of such an attack we must strike the enemy first." He went on to argue, "If we are to prevent the launching of atom bombs, guided missiles, or super-rockets against our industrial establishments, we must have a force ready to destroy these weapons at their source before they are launched." Eaker concluded by stating, "The only such weapon we have in the United States today is our long-range bomber force." Some of this, of course, could have been hyperbole and posturing in an attempt to secure more Congressional funding for the Air Force, but some strategists went even further. Colonel Louis E. Coira of the Air Force Operations Division, emphasizing the need for secrecy and speed in the

${ }^{109}$ Ibid. 
opening of a preventive nuclear war, concluded that the president "must be prepared to accept the responsibility for issuing the order [for a] preventive war."110

Military officers were not the only ones advocating preventive war against the Soviet Union. The United States had suggested, in the Baruch Plan, that international control of all atomic weapons programs be turned over to the United Nations. As a science writer who had done much to popularize the atomic bomb, William L. Laurence proposed that the United States initiate a new approach to the issue if the Soviet Union would not agree to the Baruch Plan. He argued that any nation refusing to renounce its sovereign right to manufacture nuclear bombs would be making itself an aggressor nation subject to UN Charter sanctions. He advocated that in the circumstances of such aggression, Congress should authorize the President "to take whatever action is necessary to meet the challenge of the aggressor." The aggressor, in his view, was to be prevented from continuing the production of nuclear weapons. He argued that the Kremlin should be told, in effect, that the U.S. would be compelled to "destroy your atomic plants before they are ready to operate.... If that means war, it will be a war you will force on us by your insistence on an atomic armaments race which must inevitably lead to war anyway.... Under the circumstances it would be to our advantage to have it while we are still the sole possessors of the atomic bomb."

Former Secretary of War Henry L. Stimson, like Ambassador Davies and Secretary Wallace, viewed preventive war with much skepticism. Stimson called preventive war proposals "worse than nonsense." He argued that preventive war ideas

\footnotetext{
${ }^{110}$ Ibid., 331.
}

${ }^{111}$ Ibid., 331-32. 
result "from a cynical incomprehension of what the people of the world will tolerate from any nation.... We could not possibly take that opportunity without deserting our inheritance. Americans as conquerors would be tragically miscast.” John Foster Dulles seemed to agree with Stimson by suggesting that it was unthinkable that the United States would start a preventive war. Perhaps alluding to the comments made by members of the military, he argued, "military factors were not to be ignored, but in accordance with American tradition, let the military be an instrument of national policy, and not in itself the maker of that policy."

Secretary of Defense Louis Johnson, in private talks, and Secretary of the Navy Francis P. Mathews, in a speech at the Boston Navy Yard, suggested that the United States should be willing to pay "even the price of instituting a war to compel cooperation for peace." This was generally understood as a proposal to launch a preventive war against the Soviet Union. The State Department hastened to repudiate the idea as not representing official American foreign policy. ${ }^{113}$

Some American military leaders, concerned with the direct competition between the United States and the USSR in the production of atomic bombs, advocated the preventive use of nuclear weapons against the Soviet Union before it had produced a substantial number of bombs. Major General Orvil A. Anderson, commandant of the Air War College, assuming that Russia would use its nuclear weapons when it had the appropriate capability, expounded in classes and publicly on how a preventive war through the use of strategic bombing could and should be carried out. Anderson was taking the "cold war" metaphor literally. In his view, he was not advocating

${ }^{112}$ Ibid., 332. 
preventive war since the United States and the Soviet Union were already at war, but simply suggesting preventive moves within an already existing state of war. He thus argued:

Since we're at war, damn it, I don't advocate preventive war, I advocate the shedding of illusions. I advocate saying to Stalin: 'Joe, you're not kidding anybody. You are saying you're going to destroy us?' And if he says 'yes'—and he has been saying 'yes' all the time-we must conclude civilization demands that we act. Give me the order to do it and I can break up Russia's five A-bomb nests in a week.

For these remarks, Anderson's superiors suspended him from his office and later dispensed with his services altogether, explaining that the Air Force's primary purpose was "the prevention of war" and not the execution of a preventive war. ${ }^{114}$

With a show of righteousness, the Soviets protested that the warlike statements of some Americans violated a UN General Assembly resolution against war propaganda. Soviet Deputy Foreign Minister Andrey Vyshinksy attacked the Western Powers as "war-mongers" and preparers of a "Pearl Harbor for the USSR." He mentioned by name a long list of enemies of the peace and of the Soviet Union, including Winston Churchill, William Laurence and General George C. Kenney, former chief of the U.S. Strategic Air Command. ${ }^{115}$

The authoritative military answer to preventive war proposals in the United States was given by the Chairman of the Joint Chiefs of Staff, General Omar Bradley, whom Vyshinksy had included in his list of warmongers. Bradley assured a congressional committee in October 1949 that "we are never going to start a war," and that his and his colleagues' strategy was therefore based on the assumption that the United States would wait to be attacked. This was something that sober-minded military men had

\footnotetext{
${ }^{114}$ Ibid.

${ }^{115}$ Ibid., 332.
} 
told the public before. But, he added, after allowing the enemy to strike first, "we will have to carry the war back to the enemy by all means at our disposal." 116

As can be gleaned from some of the statements above, the Truman Administration had to contend with an influential school of military members who were becoming increasingly political. These politicized military leaders were less respectful of the boundaries of the policymaking domain usually reserved for civilian control. These men were ready to discard the American tradition against aggressive or preventive war as outdated. President Truman answered these calls for preventive war by reiterating the traditional American view that preventive wars were "the weapons of dictators, not of free democratic countries like the United States, arming only for defense against aggression."117 The Truman administration never seriously considered taking advantage of Soviet vulnerabilities in so cold-blooded a way.

Gaddis argues that there were several reasons for this lack of preventive action on the part of the U.S.:

First, however things may have appeared in retrospect, it was not all that clear at the time that the United States enjoyed so decisive a military edge over the Soviet Union. Second, moral considerations - and their very realistic political implications - also discouraged any serious thought of initiating military action against the Soviet Union. Third, there was the growing realization that the total elimination of adversaries can cause more problems than it solves. ${ }^{118}$

There was also a sense that the Soviet government — unlike the adversaries of World War II-was redeemable. Gaddis points out, "It is significant that this

\footnotetext{
${ }^{116}$ Ibid., 333.

${ }^{117}$ Ibid., 333-34.

${ }^{118}$ Gaddis, The United States and the End of the Cold War: Implications, Reconsiderations, Provocations, 24.
} 
viewpoint existed prior to the Soviet Union's acquisition of atomic weapons and of a retaliatory capacity that could be used directly against the United States.",119

Men who prided themselves for holding to the best traditions of democracy echoed the conviction that no preventive war should be undertaken, even as part of the so-called "cold war." A barrage of speakers, civilian and military, had to offset statements by American politicos—-both in and out of uniform — who favored preventive war against the Soviet Union. General Omar Bradley assured the American people and armed forces alike that "we will not provoke a war against anybody. And we will not wage a preventive war against an archenemy." In May 1951, while testifying before Congress, Senator Harry P. Cain of Washington asked General Bradley “May I ask if you believe in a preventive war?” General Bradley responded, "I do not, because I do not believe that is a solution.",120

Furthermore, Secretary of State Dean Acheson declared that proposals in favor of a preventive war were "self-defeating. It is only among those who have lost their sense of proportion about the purpose for which we need to build our military strength that talk of preventive war is possible. Only among those who have lost sight of our goals can there be wisdom in self-destructive hysteria."121

In the final analysis, then, while there were certainly Americans advocating the use of preventive action, and specifically preventive war against the Soviet Union, there were also serious constraints on these individuals. Whether it was a concern at the highest levels about American capability or moral restraint, from the above

\footnotetext{
${ }^{119}$ Ibid., 24-25.

${ }^{120}$ Vagts, Defense and Diplomacy: The Soldier and the Conduct of Foreign Relations, 333-34. See also Christopher M. Gacek, The Logic of Force: The Dilemma of Limited War in American Foreign Policy (New York: Columbia University Press, 1994), 66-67.

${ }^{121}$ Vagts, Defense and Diplomacy: The Soldier and the Conduct of Foreign Relations, 333-34.
} 
evidence it seems that the civilian leadership did not consider preventive war a viable option against the Soviet Union. Instead, the policy of containment was seen as more pragmatic. Containment is, of course, a form of preventive action in and of itself, however.

We must conclude that had there been severe political constraints on Americans who advocated preventive action, and specifically preventive war, there would have been far fewer advocates and far fewer willing to express their views publicly. Since we have multiple examples of fairly prominent individuals advocating preventive action, an argument can be made that the political constraints were moderate. Given this reasoning, the typology once again performs well, predicting a mix of strategies: the use of incentives, coercion, and confrontational diplomacy.

\section{Germany}

In the case of Germany, there seems to have been much less talk about prevention, both in the last half of the nineteenth century and the first half of the twentieth century. Part of this is undoubtedly due to a rather militarily weak United States during this period. Secretary Bayard's statement that the U.S. would not allow any single country to gain a commercial monopoly in the Samoan islands is rather vague. Despite the general lack of discussion regarding prevention, the U.S. did act forcefully in the Samoan affair. Had it not been for a typhoon, it is possible that military confrontation could have arisen between the U.S. and Germany. In this instance, the typology does not seem to perform well. There seems to be severe 
political constraints and yet the United States engaged in confrontational diplomacy and even a show of military force.

In the run-up to the Second World War, the United States at first did nothing. Then during and after 1938, the United States started more openly supporting France and Britain, and shoring up support in Latin America. Senator Norris' remarks regarding preventive war and the recommendations of the American General Staff suggest that the ideas of prevention were on the minds of some American decision makers. Because there were at least some discussions of preventive measures, we can conclude that there were moderate political constraints. In this case, the typology performs somewhat well. While no incentives were really offered to Hitler, coercion and confrontational diplomacy were eventually initiated by the United States.

$\underline{\text { Japan }}$

As mentioned earlier, the rise of Japan in the 1860 s and 1870s was not viewed by most Americans as threatening, and therefore did not lend itself to thoughts of preventive action. The rise of Japanese power in the 1930s, however, was seen as a threat to American interests in Asia, but the United States was largely on a defensive military footing and was unable or unwilling to take substantial economic and diplomatic steps to curb Japanese ambition. There was, in fact, little discussion of preventive action aimed at Japan before the late 1930s. It was only with the ending of the commerce treaty and then later with the economic embargo of oil that the U.S. became serious about preventing the further rise of Japan. This later event, unfortunately, is outside the scope of this study. For the time period being examined 
here, American political constraints regarding preventive action against Japan seem to have been rather severe. With the Neutrality Act of 1935, the United States really turned its back on Asia. The typology is correct in predicting that under such circumstances, the United States would do nothing to stop the rise of Japan.

In the post World War II environment, of course, the relationship between Japan and the U.S. was quite different. During this period, the competition between the two countries was purely economic. While there was some discussion of economic retaliation against Japan during this period, it was not so much of a preventive nature as a punishment for Japanese trading policy and an inducement to have those policies changed. Again, in this case, my typology either fails or is not really applicable in the first place.

\section{United Kingdom}

Again, the DPMP does not seem applicable in the relationship between Britain and the United States. If it were applied, we would have to conclude that there have been severe political constraints regarding any discussion of preventive action against the United Kingdom. Therefore, as predicted by the typology, the U.S. did nothing to stop the relative increase in British power either before or after World War II.

\section{3) What is the nature of the ruler belief system?}

$\underline{\text { Russia/Soviet Union }}$

American leadership during the nineteenth century in regards to Russia can be described as moderate-pragmatic or even moderate-acquiescent after the sale of 
Alaska. Despite relatively minor issues of oil and human rights, Russia was much less on the minds of American policymakers than were some of the other major powers. The typology predicts that the American government should largely do nothing or accommodate the Russians. In this instance, the typology seems to be correct.

The leadership of the Roosevelt administration during the 1930s also fits the moderate-pragmatic mold. Roosevelt seemed willing to accommodate the Soviets and even offer them incentives even when the Soviets seemed to move closer to Nazi Germany. This behavior is accurately predicted by my typology, though not the specifics of that behavior.

American-Soviet relations in the post World War II era also seem to fit well with the typological predictions. President Truman and his advisors clearly were either moderate-pragmatic or perhaps even pragmatic-militant in orientation. The policy of containment, in its different variations, continued to cast this hardnosed shadow across the rest of the Cold War. Successive administrations continued to straddle this moderate-pragmatic/pragmatic-militant line. With these tendencies in mind, the typology seems to predict accurately the form American foreign policy would take during much of the Cold War.

\section{Germany}

While the ruler belief system was not significantly different in terms of its orientation toward Germany than it was toward Russia in the nineteenth century- the U.S. leadership took a pragmatic-militant approach—its view of the threat posed by Germany was quite different. This had a significant impact on the foreign policy of 
the United States during this period. Because of the American perception that Germany posed a threat to U.S. interests, the typology does not do a good job of predicting the outcome of American foreign policy. I will address the issue of threat in the next section.

It can be argued that the American leadership was moderate and pragmatic during the run-up to World War II. The typology does a reasonable job in predicting American foreign policy during this time. The U.S. did, in fact, accommodate the rise of Nazi Germany, especially in the early years of the Third Reich. It then slowly started to shift toward more of a carrot and stick diplomacy by arming the British and the French.

$\underline{\text { Japan }}$

The ruler belief systems of the American leadership towards Japan in the midnineteenth century would have to be classified as moderate-acquiescent to moderatepragmatic. It also helped that the Japanese, during this period, were seen as becoming more like the United States in terms of ideology and development. The typology accurately predicts that American leaders should acquiesce or accommodate the rise of Japan during this period.

During the 1930s, because of the United States' own military weakness, the Roosevelt administration maintained a moderate-pragmatic stance. The U.S. tended to accommodate the ever more aggressive Japanese, especially until about 1938. Under these circumstances, the typology predicts everything from accommodation to rewards and penalties. After 1938, the Roosevelt administration began to shift to a 
more pragmatic-militant orientation. The typology does seem to predict fairly accurately American foreign policy in the run-up to World War II, especially in the later years of the 1930s when the United States started to take a more aggressive stance in regards to Japanese maneuvers in Asia.

American leadership in the 1960s, 1970s, and 1980s was largely moderateacquiescent to moderate pragmatic. The typology would suggest that the United States should do nothing to stop the rise of Japan, or should at the most use a mixed strategy of incentives and coercion in its relations with Japan. This is, in fact, what we see when looking at the foreign policy of the United States. Even in the late 1970s and early 1980s at the height of economic tensions between the two countries, talk of economic retaliation against Japan was relatively mild.

\section{United Kingdom}

In both the decade before World War II, and the decades since, American leadership regarding Britain has been moderate-acquiescent to moderate-pragmatic. The typology has accurately predicted that the United States would either acquiesce in the face of British growth or would accommodate the UK.

\section{4) What is the nature of the threat (military, non-military)?}

\section{$\underline{\text { Russia/Soviet Union }}$}

Russia (at least since removing itself from the North American continent with the sale of Alaska) and the Soviet Union have never posed an economic threat to the United States. As mentioned earlier, with the sale of Alaska, the Russian threat to the 
United States was minimized for the remainder of the nineteenth century. Nor did the Soviet Union really pose a military threat to the United States prior to the Second World War. However, because the early Soviet Union was not seen as a military threat, but an ideological one, my typology may be seen as accurately predicting that the U.S. would accommodate the Soviet Union. ${ }^{122}$ Diplomatic recognition and cooperation during World War II would seem to be in line with this prediction.

The Soviet Union, on the other hand, did pose a militarized threat to the United States after the Second World War. However, it is clear from the thinking of George Kennan and the authors of NSC-68 that the Soviet leadership was considered a rational actor that would not be willing to take unreasonable military risks. They believed that the Soviet Union could be contained and waited out. The Soviet Union, then, was seen by the majority of American decision makers as a moderatemilitarized threat. This, as predicted by the typology in figure 6.1, resulted in sustained coercive and confrontational diplomacy in the form of the containment policy during the Cold War period.

\section{Germany}

During Bismarck's attempted incursion into Latin America and later during the Samoan Crisis, Germany posed both a militarized and economic threat. The threat, however, on both accounts was fairly moderate. Given this view of the threat, the typology accurately predicts the use of confrontational diplomacy and a show of force (in the case of Samoa).

\footnotetext{
${ }^{122}$ This element of an ideological challenge is one that is not captured in my model. This may be a further
} refinement that needs to be added in further iterations of this research. 
German remilitarization in the 1930s also presented a challenge to the United States. This combined with the ideological differences between the two countries and the human rights violations of the Third Reich created a tense atmosphere. The rearming of Germany was clearly seen as a threat to American allies in Europe, particularly Britain and France. President Roosevelt took steps to supply them with arms in preparation for any conflict that might arise with Germany. He also consolidated support in Latin America as a shield against possible German attempts to gain a foothold in the Western Hemisphere. In this case, the typology does not seem to fail completely, but there are clearly nuances in American foreign policy that are not being captured by the typology.

$\underline{\text { Japan }}$

During the 1860s and 1870s, Japan was seen as a possible competitor in Asia. However, this was tempered by the general view that Japan was becoming ideologically similar to the United States, and therefore any future conflicts were seen as solvable through normal diplomatic and economic channels. Therefore, the threat was low and non-militarized. The typology accurately predicts that the United States would largely do nothing as Japan gained power.

The situation was different in the 1930s. As the decade progressed, Japan was seen as more of a military threat to U.S. interests in Asia and a challenge to the international order. As the 1930s wore on, American leaders came to see Japan as first a moderate militarized threat, then perhaps even a high militarized threat. In this case, the typology suggests that the U.S. should have taken more aggressive measures 
earlier than it did vis-à-vis Japan. Part of the reason for this discrepancy, as indicated earlier, is that the U.S. was not in a strong military position to act more forcefully.

In the post World War II era, Japan presented a low to moderate non-militarized threat to the United States. The challenge from Japan during this period was economic. Therefore, the typology does a good job predicting the behavior of American foreign policy during this time.

\section{$\underline{\text { United Kingdom }}$}

The threat from the UK in the 1930s and after World War II, if there was any threat at all, would have to be classified as low non-militarized. The typology accurately predicts that American foreign policy should be acquiescent in these circumstances. It is not surprising that the American government did nothing (or very little) to prevent the relative rise in power of the United Kingdom.

\section{5) To what extent is conflict seen as likely or inevitable?}

\section{$\underline{\text { Russia/Soviet Union }}$}

It is clear that conflict with Russia in the nineteenth century was perceived as being unlikely. This would lead the DPMP to predict that non-militarized preventive action would be unlikely. In this instance, our model is correct; no preventive action was taken by the United States against Russia during this period.

In the years 1925 to 1933 , it seems that the U.S. government did not view conflict with the Soviet Union as likely. On the contrary, the policy of non-recognition would suggest that the U.S. was willing to wait for isolation and time to take its toll on the 
Soviet regime. Between 1933 and 1938, however, we see a warming of relations between the two countries, though strains were placed on the relationship because of Stalin's overtures toward Hitler. Nonetheless, during this period, conflict between the United States and the Soviet Union was not seen as likely. In this instance, the DPMP is correct; no preventive action was taken by the United States against Russia during this period.

Finally, during the Cold War, it is clear that some Americans felt that conflict with the Soviet Union was inevitable and pushed for preventive action. This view, however, did not dominate the American foreign policy establishment. Instead, containment suggested that if the U.S. were able to stop the spread of communism, its internal contradictions would ultimately force the Soviet regime itself to change. War was seen as possible, but not at all inevitable. I would classify the perceived likelihood of war - at least for the key decision makers - as low. Given this (and other factors mentioned below such as status quo and cost of militarized action), the DPMP accurately predicts that preventive action was likely, but that non-militarized preventive action might be preferred. Containment is a form of non-militarized preventive action and was the preferred method of dealing with the Soviet Union after World War II.

\section{Germany}

Germany in the nineteenth century actually presented both a militarized and nonmilitarized threat to the United States. While it is difficult, from the research done in this project, to determine how the American leadership felt about the possibility of 
conflict with Germany, it seems reasonable, given German incursions into Latin America and Samoa — and their relatively close proximity to the United States — that some Americans would see conflict with Germany as at least somewhat likely. I would rate this as high on the DPMP. However, given other factors such as cost which will be discussed below, non-militarized preventive action may have seemed the more prudent course as predicted by the model. For the most part, this is correct, though militarized preventive action was certainly possible after the U.S. and Germany sent warships to Samoa. Thanks to the typhoon, however, we will never know if militarized conflict was in the cards.

Conflict with Germany from 1920 to 1933 was probably not a real possibility.

The Weimar Republic was not seen as a threat by the United States despite it growth. After 1933, however, and the remilitarization of Germany under the Nazis, Germany was increasingly seen as a militarized threat to America's allies. As the 1930s wore on and Germany appeared increasingly aggressive, the likelihood of conflict also increased. However, due to the likely cost of militarized action, non-militarized preventive action may have been preferred. This is predicted by the DPMP.

$\underline{\text { Japan }}$

Japan in the nineteenth century, as mentioned earlier, was not seen as a threat by either the American public or the American leadership, though it was viewed as a potential competitor. Japan in the 1930s, however, was increasingly perceived as a militarized threat. Conflict was seen as increasingly likely as the 1930s wore on. However, once again, because of the anticipated costs of such action, non-militarized 
preventive action was chosen as the more prudent course of action, as predicted by the DPMP.

Japan in the post World War II era has presented an economic challenge to the United States. As predicted by our model, non-militarized preventive action would be the preferred method to deal with such a circumstance. However, given that the likelihood of conflict would have been low and that the general feeling in the U.S., particularly in the late 1970s and early 1980s, was that the status quo was getting worse for the United States, non-militarized preventive action should have been seen as a possibility. The wave of "Japan bashing" and discussion in the halls of Congress would suggest that economic retaliation was indeed considered. However, the DPMP also suggests that if the cost of non-militarized preventive action is high, then preventive action is unlikely. This seems to have played out in American foreign policy. A trade war with Japan would have certainly been expensive. As a result, we see very little action taken by the U.S. government during the late 1970s and early 1980s.

\section{$\underline{\text { United Kingdom }}$}

As mentioned earlier, conflict was not seen as likely between the United States and the United Kingdom during the periods under consideration. Therefore, the DPMP, as far as it can be applied, accurately predicts American foreign policy. 


\section{6) To what extent do domestic elements believe that a war would not be costly?}

\section{$\underline{\text { Russia/Soviet Union }}$}

The cost of war does not seem to be a factor in determining American policy towards Russia in the nineteenth century or the period 1925-1938. Since it was such a remote possibility, there seems to have been very little emphasis placed on such calculations. After World War II, however, there were many cost calculations, and the costs were almost always considered very high, particularly after the Soviets developed their own atomic weapons. However, it was also felt by many people, particularly in the late 1940s and early 1950s that the cost of militarized conflict, while high, would only increase as time went on and the Soviets increased their military capability. Because of these two factors, the DPMP predicts that preventive action is likely, and that non-militarized preventive action might be preferred. This seems to be the thinking of the foreign policy establishment in the U.S. at the time.

\section{Germany}

War with Germany has always been viewed by the United States as being costly. As early as 1885 , Secretary of State Bayard warned that war with Germany would be a terrible thing and that the Germans could possibly shell New York City. This would have been as true in 1935 as it was in 1885 . Given that militarized preventive action in regards to Germany has always been seen as costly, it is not surprising that the United States chose to use non-militarized means to prevent the growth of German power. 
The DPMP does a decent job of predicting American foreign policy vis-à-vis Germany, with the possible exception of the show of force in Samoa. Still, a show of force is less than militarized preventive action. Had the Samoan Crisis evolved into a militarized conflict, however, our model would have incorrectly predicted the outcome.

$\underline{\text { Japan }}$

War with Japan in the 1930s was seen as costly, especially given the weakness of American military power at the time. This fact lent itself to non-militarized preventive action, if any action was going to be taken at all. This is, in fact, what occurred in American foreign policy during the period, and it is what is predicted by the DPMP.

As mentioned earlier, war with Japan in the post Second World War environment has not been presented as a viable option by any American administration. Japan has been a close American ally for the past sixty years. However, should war occur between the two countries, it would be unbelievably expensive since Japan is one of the United States' main trading partners.

\section{United Kingdom}

As was the case with postwar Japan, war with the UK during the entire twentieth century has been all but unthinkable from a U.S. perspective. The close alliance between the two countries precludes any such calculations. The DPMP simply does not apply to this case for this variable. 


\section{7) To what extent is there the belief that a war now would be less costly than a war later?}

\section{$\underline{\text { Russia/Soviet Union }}$}

Since war was really only an option after the Second World War, I will not discuss the other periods here. As seen earlier, there were Americans, particularly some military officers, who felt that war with the Soviet Union would only become more costly as time went on and the Soviets rebuilt their military. This calculation probably permeated to the top of the American government, but the most powerful decision makers clearly felt that the U.S. could not engage in preventive war for moral and ideological reasons. The DPMP does not take into account moral and ideological elements of decision making, but the fact that military action against the Soviet Union was seen as costly suggests that the United States should have looked to non-militarized means of dealing with the Soviet Union. This is predicted by the model and it reflects reality very well.

\section{Germany}

From the evidence gathered in this research, there is no clear indicator of how the American leadership felt about the cost of future war with Germany either in the nineteenth century or in the run-up to World War II. It is clear, however, that war with Germany was always seen as costly, and this was enough to preclude militarized preventive action. The DPMP predicts that if any preventive action is to be taken, it will be of a non-militarized nature. This is, in fact, how American foreign policy proceeded in regards to Germany during the periods under investigation. 
$\underline{\text { Japan }}$

There is evidence to suggest that by the late 1930s, American leadership felt that the longer they could delay conflict with Japan, the better the chances for the United States. It was only in 1938 that the U.S. began to earnestly rearm and to begin rebuilding the U.S. Navy. Therefore, it is reasonable to assume that American leadership wished to postpone any war with Japan for as long as possible to give these rearmament programs a chance to bear fruit. Therefore, since militarized preventive action would be seen as more costly in the short term than it would be in the longer term, the DPMP predicts that non-militarized preventive action, if any, might be preferred. This seems to be reflected in American policy toward Japan in the 1930s.

\section{$\underline{\text { United Kingdom }}$}

Since war was not a real possibility between the UK and the U.S., I will not address this issue here.

\section{8) To what extent is there the belief that the chances of winning a war now would be greater than the chances of winning a later war?}

\section{$\underline{\text { Russia/Soviet Union }}$}

Similar to calculations of the costs of war, for American policymakers after World War II, it seemed that the odds of winning a war would decrease as the Soviets rebuilt their military machine. However, as discussed earlier, the costs of war in the 
first place precluded most high-level discussions of preventive war against the Soviet Union. This is accurately predicted by the DPMP.

\section{Germany}

There is no real evidence, other than the comments of Secretary of State Bayard, that suggest the thinking of the American leadership regarding the probability of winning a war with Germany. The costs seem to have been seen as prohibitive, so no real discussion of a now-versus-later type took place. Nonetheless, because of the perceived costs, according to the DPMP, non-militarized options would have been preferred. This is reflected in reality.

$\underline{\text { Japan }}$

As stated earlier, it is conceivable that by the late 1930s, American leadership felt that the longer they could delay conflict with Japan, the better the chances for the United States. Because of the relative late start in rearming, it is reasonable to assume that American leadership wished to postpone any war with Japan for as long as possible to give these rearmament programs a chance to bear fruit. Therefore, since militarized preventive action in the short term would be seen as less likely to succeed than it would in the longer term, the DPMP predicts that non-militarized preventive action, if any, might be preferred, at least until the United States had sufficiently built up its military power. This seems to be reflected in American policy toward Japan in the 1930s. 


\section{$\underline{\text { United Kingdom }}$}

Since war was not a real possibility between the UK and the U.S., I will not address this issue here.

\section{9) To what extent do domestic elements think the status quo will get worse for their state if the rising challenger is allowed to continue its ascendancy?}

\section{Russia/Soviet Union}

In regards to Russia and then the Soviet Union, there does not seem to have been a concern about the status quo prior to World War II. However, after the war, there does seem to be this pervasive feeling that the status quo would get worse for the United States vis-à-vis the Soviet Union. The Soviet development of the atomic bomb, communist gains in China, and then the outbreak of the war in Korea only reinforced these concerns. However, given the cost of militarized conflict, the DPMP accurately predicts that the U.S. would engage in non-militarized preventive action during the Cold War.

\section{Germany}

It is difficult to extract American thoughts regarding the status quo vis-à-vis Germany in the 1870 s and 1880 s. Germany was a rising power to be sure, but so was the United States. The overall lack of discussion regarding the future of the status quo would lead us to assume that this was not a major concern of American decision makers. If this were correct, then the DPMP would assume that any preventive action taken on the part of the United States would be of a non-militarized nature. This 
would be correct, with the possible exception of the potential outbreak of hostilities over Samoa had nature not intervened.

Germany in the 1920s, as mentioned above, was not of particular concern to the American foreign policy establishment. However, upon the ascendance of Adolf Hitler and the remilitarization of Germany, there was increasing unease about the rising power in Europe. Still, there does not seem to have been a lot of discussion about a deteriorating status quo. Americans were more concerned about their crippled economy than what was happening across the Atlantic Ocean. There does not seem to be a perception that the status quo is worsening for the United States. If this is accurate, then the DPMP correctly predicts that the United States, if it were going to do anything, would engage in non-militarized preventive action.

\section{$\underline{\text { Japan }}$}

The status quo was clearly deteriorating in relation to a rising Japan during the 1930s, but this did not seem to be a major concern of American leadership for most of the decade. Americans, as mentioned before, were focused largely on the domestic economy and were trying to avoid getting involved in international conflicts. The American concern, at least until 1937, seems to have been more about fair access to China than with the rise of Japanese power and Japanese militancy. Therefore, while the status quo was objectively deteriorating, the American leadership and American public do not seem to have noticed or cared until around 1938. Given this, we have to answer "no" to the question "Will the status quo continue to worsen if no action is taken?" It seems this is the way the American leadership would have answered the 
question at the time, had they asked it. Given this, the DPMP predicts that, at least until 1938, preventive action of any kind was unlikely.

After 1938, the awareness of the deteriorating situation seems to have been more clearly defined in the minds of American decision makers. However, there is little direct evidence from the research here to suggest that the leadership was framing it in terms of a deteriorating status quo projected into the future. This is problematic for our model, since if we answer "yes" to this question, the DPMP accurately predicts U.S. foreign policy after 1938. If we answer "no" to this question, our model continues to predict no preventive action, which is incorrect. We must conclude, therefore, that on this question, we simply do not have adequate information to determine definitively the success or failure of the DPMP.

American leaders and the American public during the 1970s and early 1980s certainly saw Japan as an economic challenge and did see the status quo as continuing to worsen. This lead to "Japan bashing," but little else. Our model predicts that, because non-militarized preventive action would have been costly given the important trade that occurred with Japan, the U.S. should not take any preventive action. This, in fact, is what occurred during the period under consideration.

\section{$\underline{\text { United Kingdom }}$}

There is no discussion of the status quo vis-à-vis the United Kingdom during this period. Furthermore, it seems unlikely that had the status quo been seen as deteriorating, this would have made any difference in British-American relations 
during the periods being examined here. The United States has shown a tendency to accommodate rising powers with which it has good relations.

\section{0) What is the nature (polarity) of the international system?}

John Mearsheimer suggests that the period 1816-1902 was characterized by balanced multipolarity (war somewhat likely), while the period 1903-1918 was characterized by unbalanced multipolarity (war most likely). The period 1919 to 1938 constituted a balanced multipolar system (war somewhat likely) while 1939 to 1945 was an unbalanced multipolar system (war most likely). Finally, the period 1947 to 1990 was bipolar (war most unlikely). According to his theory of offensive realism, war was therefore somewhat likely from 1816 to 1902 and again from 1919 to 1938. War was most likely during the periods $1903-1918$ and 1939 to $1945 .{ }^{123}$ One question this theory does not answer is this: Why did war occur in 1914 and not, in say 1910 when the structure was the same? Mearsheimer's model comes up short in answering this puzzle.

The typology of preventive action developed in this study also incorporates Mearsheimer's concepts of polarity (see table 6.1 above). Within the typology, a "balanced multipolar" system suggests that the United States should have acquiesced or have used a mixed strategy, which is at least partially correct. In the case of Russia and then the Soviet Union, up until 1938, the typology accurately predicts American foreign policy. It also accurately predicts American reaction to the increasing power of the UK during the 1930s. In relation to Japan in the 1860s and 1870s, the U.S. certainly acquiesced to its rise. In the 1930s, the U.S. acquiesced or accommodated

${ }^{123}$ See John J. Mearsheimer, The Tragedy of Great Power Politics (New York: W. W. Norton \& Company, 2001). 
Japan, again in keeping with our typology. The U.S. response to Germany in the 1870 s and 1880s, as noted however, was more forceful. In the case of Germany, our typology does not perform well on this variable. In the 1920s and 1930s, the U.S. largely did nothing as Germany rose, again suggesting our typology is correct. However, this begins to break down after 1938 when the U.S. began to supply arms to Britain and France. However, as Mearsheimer suggests, in 1939 the world became an unbalanced multipolar system in which these actions would be completely appropriate. Similarly, after 1938 the U.S. started to take a tougher stance against Japan, again in conjunction with the shift toward an unbalanced multipolar system. Our typology seems to hold up fairly well in all of these cases except Germany in the 1870 s and 1880s.

The classification of a bipolar system in the post World War II era is less helpful. Our typology predicts everything from acquiescence to accommodation to confrontational diplomacy. It is no surprise, then that American foreign policy during this time can fit into one of these three categories vis-à-vis the Soviet Union, Japan, and the United Kingdom. While accurate, the typology is not very instructive for these cases during this period.

\section{1) What type of government exists in each state, i.e., are either or both} democracies? $^{124}$

Between 1863 and 1867, the United States is classified as a democracy (it is actually classified as a democracy for the entire period under investigation) while

\footnotetext{
${ }^{124}$ See Ibid. See also Randall L. Schweller, "Domestic Structure and Preventive War: Are Democracies More Pacific?," World Politics 44, no. 2 (1992).
} 
Japan and Russia are both classified as autocracies. Therefore, according to Schweller's model, the U.S. should have formed a defensive alliance against both. In this case, Schweller's model does a poor job of predicting American foreign policy. The United States actually tended to favor Japan during this period, and AmericanRussian relations were quite friendly during this period.

From 1868 to 1877, Prussia/Germany and Russia are classified as autocracies. At the same time, Japan is classified as an anocracy. According to Schweller's model, the United States should have formed a defensive alliance against all three. In this instance, Schweller's model does better in predicting America's foreign policy behavior against Germany. American-Russian relations also cooled during this period, but not to the point where the United States was seeking alliances against Russia. Japan continued to enjoy good relations with the United States during this period, counter to the predictions of Schweller's model.

For the period 1878-1888, both Germany and Japan are classified as anocracies and Russia is still classified as an autocracy. Schweller's model predicts that the United States should form a defensive alliance against all three. Schweller's model again does a decent job of capturing an overall negative relationship between the United States and Germany, but it does less well in its prediction of RussianAmerican and Japanese-American relations.

Between 1920 and 1932, Germany and Japan continue to be classified as anocracies and the Soviet Union is classified as an autocracy. The United Kingdom emerged on the scene in 1930 as a new challenger to the United States, but it is classified as a democracy. Schweller's model predicts that the United States should 
form a defensive alliance against Germany, Japan, and Russia; but it should accommodate the rise of the UK. Schweller's model accurately predicts American behavior to the relative rise in power of the United Kingdom. It does less well in its prediction in regards to the other three.

From 1933 to 1939, the Soviet Union and Germany are classified as autocracies, Japan is classified as an anocracy, and the United Kingdom is classified as a democracy. Therefore, according to Schweller's model, the United States should have formed a defensive alliance against the Soviet Union, Germany, and Japan; and should have accommodated the rise of the UK. Again, Schweller's model accurately predicts American foreign policy behavior regarding the UK. His model also captures the emerging alliance against Germany and Japan. However, there is no similar alliance forming against the Soviet Union.

For the period 1946 to 1951, the Soviet Union is classified as an autocracy and the United Kingdom is classified as a democracy. Schweller's model predicts that the U.S. should form a defensive alliance against the Soviet Union, but it should accommodate the rise of the UK. In this case, Schweller's model is completely accurate.

Between 1953 and 1970, both the United Kingdom and Japan are classified as democracies, while the Soviet Union continues to be classified as an autocracy. Schweller's model predicts that the U.S. would accommodate the rise of both Japan and the UK, but that it would form a defensive alliance against the Soviet Union. Schweller's model is completely accurate for this period. 
From 1971 to 1982, both the United Kingdom and Japan are classified as democracies. Therefore, Schweller's model predicts that the United States would accommodate their rise in power. Schweller's model is completely accurate for this period.

Finally, from 1983 to 1996, the UK is classified as a democracy. Once again, Schweller's model predicts that the U.S. would accommodate the UK's ascendance. Schweller's model is completely accurate for this period. 


\begin{tabular}{|c|c|c|c|c|c|c|}
\hline $\begin{array}{c}\text { Time } \\
\text { Period }\end{array}$ & Power Distribution & $\begin{array}{l}\text { United } \\
\text { States }\end{array}$ & United Kingdom & Prussia/Germany & Japan & $\begin{array}{c}\text { Russia/ } \\
\text { Soviet Union }\end{array}$ \\
\hline \multirow[t]{2}{*}{$1863-1867$} & Balanced Multipolar & \multirow[t]{2}{*}{ Democracy } & & & Autocracy & Autocracy \\
\hline & War Somewhat Likely & & & & Defensive Alliance & Defensive Alliance \\
\hline \multirow[t]{2}{*}{$1868-1877$} & Balanced Multipolar & \multirow[t]{2}{*}{ Democracy } & & Autocracy & Anocracy & Autocracy \\
\hline & War Somewhat Likely & & & Defensive Alliance & Defensive Alliance & Defensive Alliance \\
\hline \multirow[t]{2}{*}{$1878-1888$} & Balanced Multipolar & \multirow[t]{2}{*}{ Democracy } & & Anocracy & Anocracy & Autocracy \\
\hline & War Somewhat Likely & & & Defensive Alliance & Defensive Alliance & Defensive Alliance \\
\hline \multirow[t]{2}{*}{$1920-1932$} & Balanced Multipolar & \multirow[t]{2}{*}{ Democracy } & Democracy* & Anocracy & Anocracy & Autocracy** \\
\hline & War Somewhat Likely & & Accommodation & Defensive Alliance & Defensive Alliance & Defensive Alliance \\
\hline \multirow[t]{2}{*}{$1933-1938$} & Balanced Multipolar & \multirow[t]{2}{*}{ Democracy } & Democracy & Autocracy & Anocracy & Autocracy \\
\hline & War Somewhat Likely & & Accommodation & Defensive Alliance & Defensive Alliance & Defensive Alliance \\
\hline \multirow[t]{2}{*}{1939} & Unbalanced Multipolar & \multirow[t]{2}{*}{ Democracy } & Democracy & Autocracy & Anocracy & Autocracy \\
\hline & War most likely & & Accommodation & Defensive Alliance & Defensive Alliance & Defensive Alliance \\
\hline \multirow[t]{2}{*}{ 1946-1951 } & Bipolar & \multirow[t]{2}{*}{ Democracy } & Democracy & & & Autocracy \\
\hline & War Most Unlikely & & Accommodation & & & Defensive Alliance \\
\hline \multirow[t]{2}{*}{$1952-1970$} & Bipolar & \multirow[t]{2}{*}{ Democracy } & Democracy & & Democracy & Autocracy \\
\hline & War Most Unlikely & & Accommodation & & Accommodation & Defensive Alliance \\
\hline \multirow{2}{*}{ 1971-1982 } & Bipolar & \multirow[t]{2}{*}{ Democracy } & Democracy & & Democracy & \\
\hline & War Most Unlikely & & Accommodation & & Accommodation & \\
\hline \multirow[t]{2}{*}{ 1983-1996 } & Bipolar & \multirow[t]{2}{*}{ Democracy } & Democracy & & & \\
\hline & War Most Unlikely & & Accommodation & & & \\
\hline
\end{tabular}

* The UK began to ascend vis-à-vis the United States in 1930 and that rise continued until 1939.

** The Soviet Union began to rise vis-à-vis the United States in 1925 and that ascendance continued until 1938.

Blank boxes indicate that the United States was no longer in relative decline vis-à-vis the other power or the other power had surpassed the U.S. Either condition is outside the scope of this research. 


\section{Conclusion}

American foreign policy is quite complex during the time periods under consideration in this chapter. Two major questions should be asked in deciding whether the Domestic Politics Model of Prevention is valid and worth further consideration: "How well does it predict actual American foreign policy?" and "Does it do a better job at predicting American foreign policy than other models?" I will attempt to answer these questions in this section.

\section{$\underline{\text { Russia/Soviet Union }}$}

In the case of Russia and the early Soviet Union, the DPMP performs very well. For the period of the nineteenth century, the model accurately predicts that the American government should largely do nothing or accommodate the Russians during the 1860s and 1870s. In addition, during the 1920s and 1930s, the DPMP is correct; no preventive action was taken by the United States against Russia during this period.

The behavior of the Roosevelt administration vis-à-vis the Soviet Union during the 1930s is accurately predicted by my typology, though not the specifics of that behavior. Because the Soviet Union prior to the Second World War was not seen as a military threat, but an ideological threat, my typology may be seen as accurately predicting that the U.S. would accommodate the Soviet Union.

The DPMP does a good job of predicting actual American behavior in relation to the Soviet Union during the Cold War. During this period, political constraints were moderate for American leaders. Given this condition, the typology once again performs well: predicting a mix of strategies including the use of incentives, coercion, and confrontational diplomacy. The model accurately predicts that preventive action was likely, but that non-militarized preventive action 
might be preferred. Containment is a form of non-militarized preventive action and was the preferred method of dealing with the Soviet Union after World War II. This, as predicted by the DPMP, resulted in sustained coercive and confrontational diplomacy during the Cold War period.

\section{$\underline{\text { Prussia/Germany }}$}

The DPMP struggles with American-German relations in the 1870 s and 1880s. In this case, the model seems to have a split personality. On the one hand, there seems to be severe political constraints, and therefore the typology suggests that in this case, the United States should have acted defensively and acquiesced in the face of German aggression. Yet the United States engaged in confrontational diplomacy and even a show of military force. While the U.S. did act defensively for the most part, it did not acquiesce to German demands. In this case, the DPMP also does not perform well on the variable of polarity of the international system. On the other hand, because of the American perception that Germany posed a threat to U.S. interests during the 1870 s and 1880 s, the typology accurately predicts the use of confrontational diplomacy and a show of force (in the case of Samoa) during the 1870s and 1880s.

The model is redeemed somewhat, though, regarding American-German relations on the eve of the Second World War. In the decade before the Second World War, the typology does not fail completely, but there are clearly nuances in American foreign policy that are not being captured by the typology. During and after 1938, the typology performs reasonably well. While no incentives were offered to Hitler, coercion and confrontational diplomacy were initiated by the United States. 
$\underline{\text { Japan }}$

As mentioned earlier, the rise of Japan in the 1860s and 1870s was not viewed by most Americans as threatening, and therefore did not lend itself to thoughts of preventive action. The typology accurately predicts that American leaders would acquiesce or accommodate the rise of Japan during the 1860 s and 1870 s.

Unfortunately, the DPMP does not perform as well in all instances. One variable, the perception of a deteriorating status quo vis-à-vis Japan prior to the outbreak of World War II, provides a real challenge for our model. On this variable, we simply have insufficient evidence to draw a definitive conclusion.

However, the DPMP does seem to predict accurately American foreign policy vis-à-vis Japan in the run-up to World War II. This is especially true for the later years of the 1930s when the United States started to take a more aggressive stance in regards to Japanese maneuvers in Asia. However, the model does suggest that the U.S. should have taken more aggressive measures earlier than it did vis-à-vis Japan. Part of the reason for this discrepancy, as indicated earlier, is that the U.S. was not in a strong military position to act more forcefully.

In terms of the nature of the threat from Japan in the post World War II era, the DPMP does an overall good job predicting the behavior of American foreign policy during this time. However, some variables for this period cause trouble for our model. The measurement of offensive/defensive military strategy does not seem to apply to Japan during this period given that Japan was an important ally and trading partner to the United States. In fact, the American desire in the early 1980 s to see Japan rebuild its military runs counter to my preventive action theory. The one redeeming feature in this instance, however, is that since Japan-during this period-represented an economic challenge not a military one, the U.S. had little to fear from a 
rebuilding of Japan's military capacity. In addition, some of the variables in the DPMP simply do not seem particularly applicable in this instance. For example, in looking at the cost of war or the chances of being successful in a war, the American-Japanese relationship in the post World War II era does not lend itself to this analysis.

\section{$\underline{\text { United Kingdom }}$}

The American-British relationship also poses problems for the DPMP on some variables such as internal power constraints, political constraints, the cost of war, and the chances of being successful in a war. They simply do not seem to be particularly applicable to US-UK relations. Nonetheless, the model does accurately predict American foreign policy vis-à-vis the United Kingdom on some of the other variables. Fore instance, in both the decade before World War II, and the decades since, American leadership regarding Britain has been moderate-acquiescent to moderate-pragmatic. The DPMP has accurately predicted that the United States either would acquiesce in the face of British growth or would accommodate the UK. Similarly, the threat from the UK in the 1930s and after World War II, if there was any threat at all, would have to be classified as low non-militarized. The typology accurately predicts that American foreign policy should be acquiescent in these circumstances.

\section{$\underline{\text { Alternative Models }}$}

Mearsheimer's classification of international polarity, as mentioned above, failed to predict American-German relations during the 1870s and 1880s. The classification of a bipolar system in the post World War II era is also problematic. It predicts everything from acquiescence to accommodation to confrontational diplomacy. It is no surprise, then that American foreign 
policy during this time can fit into one of these three categories vis-à-vis the Soviet Union, Japan, and the United Kingdom. While accurate, the polarity of the international system is not very instructive for some these cases.

Schweller's model also has a mixed record in its performance for these cases. For the period 1863 to 1867, Schweller's model does a poor job of predicting American foreign policy. Schweller's model also performs only moderately well when looking at Prussia/Germany, Russia, and Japan between 1866 and 1877. His model accurately predicts American behavior toward Prussia/Germany, but it misses the mark in terms of American foreign policy towards Russia and Japan. It has similar problems in the period 1878-1888. However, Schweller's model does a good job in predicting American reaction to the relative rise of the UK during the 1930s. His model also does a good job predicting an American defensive alliance against Germany and Japan, but it does not predict an alliance with the Soviet Union during the Second World War. On the upside, Schweller's model is completely accurate in its predictions for the Cold War period.

\section{Final Thoughts}

None of the models - the Domestic Politics Model of Prevention, Mearsheimer's model of offensive realism, or Schweller's democratic peace model—accurately predict American foreign policy in every instance examined in this chapter. However, it is clear that my model performs at least as well as Mearsheimer's model, and considerably better than Schweller's model for all instances except the Cold War. This would suggest that the DPMP has some value in the study of international relations. 


\section{Chapter Seven \\ Conclusion}

This dissertation has sought to answer the basic question of why dominant declining states act the way they do regarding rising challengers. In chapter one, two basic goals were established concerning the overall framework of this study: 1) broadening the concept of preventive action to include non-militarized events, and 2) a focus on leaders' perceptions of the rising challenger and the workings of domestic politics. The purpose of this approach was to capture more subtle instances of preventive action - moving beyond the traditional view of a dichotomous relationship of war-nowar-and to help us understand the domestic inputs that go into preventive action decisions.

In order to determine what causal mechanisms or variables might have a dominant influence on the process, a model was developed that captured some important factors in this decision making process. The Domestic Politics Model of Prevention, presented in chapter three, incorporates aspects of prospect theory and includes the basic causal mechanisms of internal power constraints, domestic political constraints, and ruler belief systems. The performance of this model is then compared to the performance of two well-established structural models: offensive realism and Schweller's democratic peace model.

In order to test the DPMP against the other two models, this dissertation utilizes three case studies: the decline of the United Kingdom (chapter four), the decline of Russia and the Soviet Union (chapter five), and the decline of the United States (chapter six). Within each case study, a standardized set of questions are asked of each case-in 
accordance with the method of process tracing - to determine the importance of each causal mechanism as well as the importance of the structure of the international system. As was stated at the outset, the idea was to see how my model, based largely on domestic factors, would perform in relation to the more established structural models. The hope, of course, was that the DPMP would outperform the other two models in predicting the behavior of dominant but declining states.

The purpose of this last chapter is to answer this grand question: which of these competing models does the best job of explaining how dominant declining states actually behave vis-à-vis a rising challenger? In looking at this question, several possibilities must be considered. First, it could be that only one of these models presents the best explanation for the behavior of dominants states when faced with decline and a rising challenger. Second, it could be that two of the models, when combined, provide the best explanation for this behavior. Third, it is possible that all three models provide equally adequate explanations of why dominant declining states respond to challengers the way they do.

The goal of this chapter is to tie together all the loose ends of the preceding chapters and provide an overall look at how the models performed. In order to accomplish this, each model will be reviewed in the context of each case, and their conclusions will be briefly presented again. Then, the empirical merits of these findings and their relevance to dominant declining state behavior will be discussed. Finally, it will be determined which model—or models — most convincingly explains the behavior of these dominant declining states. Finally, the implications will be mentioned and the study concluded. 


\section{The Models: Reviews and Evaluations}

In this section, I once again go through the cases in the context of each model. In order to refresh the reader's memory regarding each case, this section recaps the findings from the previous three chapters. All of these findings are summarized in Table 7.1 in the following section.

\section{Alternative Model 1: John Mearsheimer's Offensive Realism Model}

John Mearsheimer, with his theory of offensive realism, suggests that major variations of balance in the international system can affect a nation's calculations regarding the efficacy of war. Mearsheimer proposes a variety of systemic possibilities ranging from balanced bipolar systems to unbalanced multipolar systems. ${ }^{1}$ He suggests that war is most likely to occur in a system in which a potential hegemon is emerging, what he calls an unbalanced multipolarity. On the other hand, war is least likely in a bipolar system in which two powers have roughly equal amounts of power. In between these two extremes is what he calls balanced multipolarity in which several states have roughly equal power, and there is no superior state. He suggests that in such a case, war is more likely than in a bipolar system, but less likely than in an unbalanced multipolar system. $^{2}$ Mearsheimer lists the polarity of the system as follows:

1) Napoleonic era I, 1792-93 (1 year), balanced multipolarity

2) Napoleonic era II, 1793-1815 (22 years), unbalanced multipolarity

3) Nineteenth century, 1815-1902 (88 years), balanced multipolarity

4) Kaiserreich era, 1903-18 (16 years), unbalanced multipolarity

5) Interwar years, 1919-38 (20 years), balanced multipolarity

\footnotetext{
${ }^{1}$ Kenneth Waltz points out that stability and peace do not necessarily go hand-in-hand. See Kenneth N. Waltz, "The Emerging Structure of International Politics," International Security 18, no. 2 (1993).

2 John J. Mearsheimer, The Tragedy of Great Power Politics (New York: W. W. Norton \& Company, 2001), 42-46.
} 
6) Nazi era, 1939-45 (6 years), unbalanced multipolarity

7) Cold War, 1945-1990 (46 years), bipolarity ${ }^{3}$

One of the shortcomings of the offensive realism model is its tendency to categorize relations between states only as peaceful or not peaceful. In order to overcome this problem, I have modified the predictions of this model as such: if preventive actions are initiated at a higher rate during periods of unbalanced multipolarity, less so during balanced multipolarity, and still less during bipolarity, the offensive realism model will be strengthened. This modification is in keeping with Mearsheimer's original intent. If the offensive realism model is able to predict accurately whether preventive action occurs, the importance of the DPMP will be weakened. On the other hand, if the offensive realism model proves inadequate in its predictions, and the DPMP proves more accurate, my ideas should be given more importance.

\section{$* * *$ United Kingdom***}

John Mearsheimer suggests that the period 1816-1902 was characterized by balanced multipolarity, while the period 1903-1918 was characterized by unbalanced multipolarity. According to his theory of offensive realism, war was therefore somewhat likely from 1816 to 1902 and most likely during the period 1903-1918. ${ }^{4}$

According to this model, a "balanced multipolar" system suggests that Britain should have acquiesced, which is largely correct. However, in the later "unbalanced

\footnotetext{
3 Ibid. (New York and London), 348. Dale Copeland also suggests that the polarity of the system and the relationship of the declining state's military power in comparison to its economic and potential power largely determine the extent to which decline leads to war. See Dale C. Copeland, The Origins of Major War, ed. Robert J. Art, Robert Jervis, and Stephen M. Walt, Cornell Studies in Security Affairs (Ithaca, New York: Cornell University Press, 2000), 21.

${ }^{4}$ See Mearsheimer, The Tragedy of Great Power Politics.
} 
multipolar" system, the typology predicts that Britain should have used coercive/confrontational diplomacy. On this point, offensive realism does not do a good job of accurately predicting the outcome of its foreign policy decision vis-à-vis rising powers. As we have seen, British foreign policy vis-à-vis rising states from 1816 to the second decade of the twentieth century was largely acquiescent and accommodating. In essence, the UK allowed the United States, Germany, Japan, and Russia to rise relative to it, and in some cases to surpass it, with little or no effort to check their ascendance.

***Russia/Soviet Union***

John Mearsheimer suggests that the period 1816-1902 was characterized by balanced multipolarity (war somewhat likely), while the period 1903-1918 was characterized by unbalanced multipolarity (war most likely). 1919 to 1938 constituted a balanced multipolar system (war somewhat likely) while 1939 to 1945 was an unbalanced multipolar system (war most likely). According to his theory of offensive realism, war was therefore somewhat likely from 1816 to 1902 and again from 1919 to 1938. War was most likely during the periods $1903-1918$ and 1939 to $1945 .^{5}$

A "balanced multipolar" system suggests that Russia should have acquiesced or have used a mixed strategy, which is at least partially correct. However, in the later "unbalanced multipolar" system, the offensive realism model predicts that Russia should have used coercive/confrontational diplomacy, which it did not. The Soviet belief that time was on their side and that they would only continue to get stronger led to a conviction that conflict with other great powers should be avoided whenever possible.

\footnotetext{
${ }^{5}$ Ibid.
} 
The model, therefore, does not do a good job of accurately predicting the behavior of Russia/the Soviet Union in this later instance.

***United States***

Mearsheimer's classification of international polarity failed to predict AmericanGerman relations during the 1870 s and 1880 s. The classification of a bipolar system in the post World War II era is also problematic. It predicts everything from acquiescence to accommodation to confrontational diplomacy. It is no surprise, then that American foreign policy during this time can fit into one of these three categories vis-à-vis the Soviet Union, Japan, and the United Kingdom. While accurate, the polarity of the international system is not very instructive in this instance.

\section{Alternative Model 2: Schweller's Democratic Peace as a Model of Preventive}

\section{War/Action}

The second alternative model I use to test the DPMP is based on Schweller's predictions about the domestic structure of states and proclivity to initiate preventive war. Schweller argues that it is the internal domestic structure - whether democratic or notthat determines how a declining dominant power responds to a rising challenger. $\mathrm{He}$ concludes that when faced with a democratic rising challenger, democracies do not initiate preventive war, but instead accommodate the challenger. When it comes to nondemocratic challengers, however, democratic states attempt to form defensive alliance systems. Also of interest, though, is that he leaves open the possibility that a democracy may initiate preventive war against a non-democratic challenger if the dominant 
democratic state believes that such a war would not be long or costly. Meanwhile, nondemocratic states, when faced with a challenger (whether democratic or not), will either form a defensive alliance or will initiate preventive war. Accommodation is not in their nature. In all, Schweller suggests that there are four possible responses by a dominant state facing a challenger: 1) accommodation, 2) internal balancing, 3) alliance formation, and 4) preventive war. ${ }^{6}$ If Schweller's model accurately predicts the behavior of states in my cases, the importance of the DPMP will be weakened. I predict, however, that my model will outperform both Schweller's model and the offensive realism model.

***United Kingdom***

The most striking aspect of British foreign policy vis-à-vis rising states from 1816 to the second decade of the twentieth century is its acquiescence and accommodation. In essence, it allowed the United States, Germany, Japan, and Russia to rise relative to it, and in some cases to surpass it, with little or no effort to check their ascendance. The periphery was increasingly left to powerful, but for the moment at least, friendly nations. Whether the threat was economic or financial, as in the case of the United States and Germany, or primarily military — as in the case of Russia, Japan, and Germany — the United Kingdom did little to stop the rise of the threatening power. British public officials came to accept a geographically constrained form of naval superiority in which England could maintain its two-power standard only in European waters. This strategy implied coming to some accommodation with the peripheral powers and perhaps, as the European states increased their naval strength, with one or more of them as well.

\footnotetext{
${ }^{6}$ Randall L. Schweller, "Domestic Structure and Preventive War: Are Democracies More Pacific?," World Politics 44, no. 2 (1992).
} 
Between 1816 and 1879, the United Kingdom was an anocracy. During this period, Prussia/Germany and Russia are classified as autocracies and Japan as an anocracy. The United States was a full democracy during this period. Therefore, according to Schweller's model, the United Kingdom should have either formed a defensive alliance or initiated preventive war against Germany/Prussia, Japan, Russia, and the U.S. ${ }^{7}$ Of course, what we have seen is that Britain was moving toward a defensive alliance with Japan and acquiesced to American demands in the Western Hemisphere. Schweller's model does not provide an adequate explanation for this.

From 1880 to 1896, the UK was a full democracy. Germany and Russia were autocracies, Japan is classified as an anocracy, and the U.S. was a full democracy. Schweller's model predicts that the UK should have formed a defensive alliance against Germany, Russia, and Japan and should have accommodated the rise of the United States. While the UK did accommodate the rise of the U.S., it did not form a defensive alliance against Japan, but instead moved still closer to accommodation with Japan.

From 1897 to 1902, the UK was a full democracy. Germany and Russia, on the other hand, were autocracies during this period and Japan is classified as an anocracy. ${ }^{8}$ Therefore, according to Schweller's model, the UK should have formed a defensive alliance against Germany, Russia, and Japan. Contrary to this model, however, in 1902 Britain and Japan formally signed a defensive alliance. This is not explained by Schweller's model.

\footnotetext{
${ }^{7}$ All statements about the level of democracy are based on the Polity IV rating. If a state is rated 7 to 10 , then I consider it a full democracy. If it is rated a 1 to 6 it is an anocracy, and I treat it as a non-democracy. States receiving a zero or negative rating are considered autocracies by Polity IV. See Appendix C for selected Polity IV scores.

${ }^{8}$ Japan was undergoing an "adverse transition" from 1860 to 1867, and then it was an anocracy.
} 
During 1903 and 1904, the United Kingdom was a full democracy. Germany and Japan were anocracies and Russia was an autocracy during this period. Schweller's model predicts that the United Kingdom should have sought a defensive alliance against Germany, Russia, and Japan during this period. Instead, Britain and Japan were allied. Germany and Russia, however, were still seen as adversaries by British political leaders.

Between 1905 and 1913, the United Kingdom was a full democracy. Japan, on the other hand, was an anocracy during this period. Therefore, according to Schweller, the United Kingdom should have sought a defensive alliance against Japan during this period. Finally, from 1914 to 1918, the United Kingdom was a full democracy while Russia and Japan were anocracies. Therefore, according to Schweller, the United Kingdom should have sought a defensive alliance against Russia and Japan during this period. Of course, as has been seen above, this did not occur. Furthermore, it does not explain why Britain was willing to enter into a defensive alliance with Japan but not with the anocratic Germany (after 1903).

Clearly, Schweller's model has some problems when examining the case of British decline. Repeatedly, the model fails to predict accurately the United Kingdom's response to rising challengers. This casts real doubt on its usefulness as a comprehensive model in regards to preventive action.

\footnotetext{
***Russia/Soviet Union***
}

Russian and Soviet leadership had a largely optimistic view of the future for their state. Despite chronic economic and military weakness, leaders of both Imperial Russia and the Soviet Union saw their state as a great power at least equivalent to the most 
powerful states in Europe, Asia, and North America. Moreover, their belief that time was on their side and that they would only continue to get stronger led them to conclude that conflict with other great powers should be avoided whenever possible. This was taken to an extreme in communist ideology, which suggested that the capitalist nations would fight amongst themselves, and a neutral Soviet Union would be the true beneficiary of such a conflict.

This optimism about the future precluded a strong preventive school of thought from taking root in either Imperial Russia or the Soviet Union. Russia and the Soviet Union both largely accommodated rising powers, in much the same way that Britain had done, though for very different reasons. British leadership was largely resigned to a fate of declining power, while Russian and Soviet leadership were optimistic about their power potential.

Between 1816 and 1879, Russia is classified as an autocracy as is Prussia/Germany. During this period, Japan is classified as an anocracy. The United States was a full democracy during this period. Therefore, according to Schweller's model, Russia should have either formed a defensive alliance or initiated preventive war against Germany/Prussia, Japan, Russia, and the U.S. ${ }^{9}$ Many of the agreements reached during this period could be viewed as defensive alliances, so Schweller's model seems to hold up during this time. However, Russia did not engage in preventive war, or militarized preventive action of any kind during this entire period. Schweller's model seems to be at least partially correct during this period.

\footnotetext{
${ }^{9}$ All statements about the level of democracy are based on the Polity IV rating. If a state is rated 7 to 10 , then I consider it a full democracy. If it is rated a 1 to 6 it is an anocracy, and I treat it as a non-democracy. States receiving a zero or negative rating are considered autocracies by Polity IV. See Appendix C for selected Polity IV scores.
} 
From 1880 to 1896, Russia and Germany were classified as autocracies. The UK is classified as a full democracy and Japan is classified as an anocracy. Therefore, Russia should have, according to Schweller's model, formed a defensive alliance or initiated preventive war against Germany, Japan, the UK and the United States. Russia continued to be involved in European affairs, but not in an overly aggressive way. Defensive agreements were made, but no real preventive action was taken. Therefore, we must conclude that Schweller's model does not perform well in this instance.

From 1897 to 1902, Russia and Germany were still autocracies. Japan was still classified as an anocracy while the United States and the United Kingdom are classified as full democracies. ${ }^{10}$ Therefore, according to Schweller's model, Russia should have formed a defensive alliance or initiated preventive war against Germany, Japan, the UK and the United States. Again, Schweller's model somewhat predicts what Russia did during this time. Russia did not engage in preventive war, but its agreements at The Hague and elsewhere could be seen as entering into defensive alliances with other powers.

During 1903 and 1904, Russia is classified as an autocracy while Japan is classified as an anocracy. Therefore, according to Schweller's model, Russia should have formed a defensive alliance or initiated preventive war against Japan. In reality, Russia did neither. It attempted to continue its expansion in Asia, but Russia was humiliated when Japan launched a war against it in an attempt to put a halt to its expansionist dreams in Asia.

Between 1906 and 1918, Russia and Japan are classified as anocracies. Therefore, Russia should have formed a defensive alliance or initiated preventive war against Japan.

${ }^{10}$ Japan was undergoing an "adverse transition" from 1860 to 1867 , and then it was an anocracy. 
What we really see, though, is a turning inward and westward by Russia during this time. With the Japanese in Manchuria and Korea, there was less incentive for Russia to continue attempted expansion in Asia. In any case, the events in Europe began to demand more attention than events in Asia.

Between 1932 and 1946, the Soviet Union is classified as an autocracy. Germany is classified as an anocracy in 1932, but then is classified as an autocracy between 1933 and 1944. Japan is classified as an anocracy between 1932 and 1944. The United Kingdom is classified as a democracy between 1932 and 1946. Therefore, Russia should have formed a defensive alliance or initiated preventive war against all of these powers. Of course, this did not happen. The Soviet Union did not engage in preventive action during this period, and several of the agreements that it entered into were not defensive against these powers. The Soviet-German non-Aggression Pact of August 1939 was not a defensive alliance against Germany, as would be predicted by the Schweller model.

Overall, Schweller's model seems to fail at predicting Russian Soviet behavior. Despite being autocratic for most of past 190 years, Russian and Soviet strategy has largely been defensive. Only rarely has it engaged in preventive action, despite the prediction by Schweller that autocracies should be the most bellicose form of government.

$* * *$ United States***

Between 1863 and 1867, the United States is classified as a democracy (it is actually classified as a democracy for the entire period under investigation) while Japan and Russia are both classified as autocracies. Therefore, according to Schweller's model, 
the U.S. should have formed a defensive alliance against both. In this case, Schweller's model does a poor job of predicting American foreign policy. The United States actually tended to favor Japan during this period, and American-Russian relations were quite friendly during this period.

From 1868 to 1877 , Prussia/Germany and Russia are classified as autocracies. At the same time, Japan is classified as an anocracy. According to Schweller's model, the United States should have formed a defensive alliance against all three. In this instance, Schweller's model does better in predicting America's foreign policy behavior against Germany. American-Russian relations also cooled during this period, but not to the point where the United States was seeking alliances against Russia. Japan continued to enjoy good relations with the United States during this period, counter to the predictions of Schweller's model.

For the period 1878-1888, both Germany and Japan are classified as anocracies and Russia is still classified as an autocracy. Schweller's model predicts that the United States should form a defensive alliance against all three. Schweller's model again does a decent job of capturing an overall negative relationship between the United States and Germany, but it does less well in its prediction of Russian-American and JapaneseAmerican relations.

Between 1920 and 1932, Germany and Japan continue to be classified as anocracies and the Soviet Union is classified as an autocracy. The United Kingdom emerged on the scene in 1930 as a new challenger to the United States, but it is classified as a democracy. Schweller's model predicts that the United States should form a defensive alliance against Germany, Japan, and Russia; but it should accommodate the 
rise of the UK. Schweller's model accurately predicts American behavior to the relative rise in power of the United Kingdom. It does less well in its prediction in regards to the other three.

From 1933 to 1939, the Soviet Union and Germany are classified as autocracies, Japan is classified as an anocracy, and the United Kingdom is classified as a democracy. Therefore, according to Schweller's model, the United States should have formed a defensive alliance against the Soviet Union, Germany, and Japan; and should have accommodated the rise of the UK. Again, Schweller's model accurately predicts American foreign policy behavior regarding the UK. His model also captures the emerging alliance against Germany and Japan. However, there is no similar alliance forming against the Soviet Union.

For the period 1946 to 1951, the Soviet Union is classified as an autocracy and the United Kingdom is classified as a democracy. Schweller's model predicts that the U.S. should form a defensive alliance against the Soviet Union, but it should accommodate the rise of the UK. In this case, Schweller's model is completely accurate.

Between 1953 and 1970, both the United Kingdom and Japan are classified as democracies, while the Soviet Union continues to be classified as an autocracy. Schweller's model predicts that the U.S. would accommodate the rise of both Japan and the UK, but that it would form a defensive alliance against the Soviet Union. Schweller's model is completely accurate for this period.

From 1971 to 1982, both the United Kingdom and Japan are classified as democracies. Therefore, Schweller's model predicts that the United States would 
accommodate their rise in power. Schweller's model is completely accurate for this period.

Finally, from 1983 to 1996, the UK is classified as a democracy. Once again, Schweller's model predicts that the U.S. would accommodate the UK's ascendance. Schweller's model is completely accurate for this period.

\section{$\underline{\text { The Domestic Politics Model of Prevention }}$}

This dissertation suggests that a model based largely on domestic factors will yield better predictions than models based on systemic mechanisms. Causal mechanisms such as internal power constraints, domestic political constraints, and ruler belief systems will allow us to predict not only whether preventive action is likely to occur, but also what form that preventive action is likely to take. In determining the reliability of the DPMP, I examine the same cases and ask the same questions addressed in the previous two models.

***United Kingdom***

On some dimensions such as internal power constraints and ruler belief systems, the DPMP performed very well in this case study. On other dimensions such as perceived likelihood of conflict, the model failed to predict accurately British behavior. This suggests that while the DPMP is far from perfect, with some modifications it may become a valuable tool in predicting the likelihood of different forms of preventive action. 
****Russia/Soviet Union***

Overall, the DPMP performs well regarding the case of Russia and the Soviet Union. Where the model does fall short (nature of threat, expected cost of war, perceived chances of winning a war), it does not fail completely. Unfortunately, because it is correct some of the time while missing the mark at other times, we must conclude that on these dimensions, it performs poorly as a predictor of Russian/Soviet behavior. Nonetheless, when compared against the other two models, the DPMP continues to perform admirably.

$* * *$ United States***

Prussia/Germany

The DPMP struggles with American-German relations in the 1870s and 1880s. In this case, the model seems to have a split personality. On the one hand, there seems to be severe political constraints, and therefore the typology suggests that in this case, the United States should have acted defensively and acquiesced in the face of German aggression. Yet the United States engaged in confrontational diplomacy and even a show of military force. While the U.S. did act defensively for the most part, it did not acquiesce to German demands. On the other hand, because of the American perception that Germany posed a threat to U.S. interests during the 1870s and 1880s, the DPMP accurately predicts the use of confrontational diplomacy and a show of force (in the case of Samoa) during the 1870 s and 1880 s.

The DPMP performs even better regarding American-German relations on the eve of the Second World War. Though the model fails to capture all of the nuances in 
American foreign policy in the decade prior to World War II, it does a good job of predicting overall American strategy; and during and after 1938, the DPMP performs very well.

$\underline{\text { Japan }}$

As mentioned earlier, the rise of Japan in the 1860s and 1870s was not viewed by most Americans as threatening, and therefore did not lend itself to thoughts of preventive action. The DPMP accurately predicts that American leaders would acquiesce or accommodate the rise of Japan during the 1860s and 1870s.

Unfortunately, the DPMP does not perform as well in all instances. One variable, the perception of a deteriorating status quo vis-à-vis Japan prior to the outbreak of World War II, provides a challenge for our model. On this variable, we simply have insufficient evidence to draw a definitive conclusion.

However, the model does seem to predict accurately American foreign policy visà-vis Japan in the run-up to World War II. This is especially true for the later years of the 1930s when the United States started to take a more aggressive stance in regards to Japanese maneuvers in Asia. However, the DPMP does suggest that the U.S. should have taken more aggressive measures earlier than it did vis-à-vis Japan. Part of the reason for this discrepancy, as indicated earlier, is that the U.S. was not in a strong military position to act more forcefully.

In terms of the nature of the threat from Japan in the post World War II era, the DPMP does an overall good job predicting the behavior of American foreign policy during this time. However, some variables for this period cause trouble for our model. 
The measurement of offensive/defensive military strategy does not seem to apply to Japan during this period given that Japan was an important ally and trading partner to the United States. In fact, the American desire in the early 1980s to see Japan rebuild its military runs counter to the preventive action theory. The one redeeming feature in this instance, however, is that since Japan—during this period—represented an economic challenge not a military one, the U.S. had little to fear from a rebuilding of Japan's military capacity. In addition, some of the variables in the DPMP simply do not seem particularly applicable in this instance. For example, in looking at the cost of war or the chances of being successful in a war, the American-Japanese relationship in the post World War II era does not lend itself to this analysis.

\section{United Kingdom}

The American-British relationship poses problems for the DPMP on some variables such as internal power constraints, political constraints, the cost of war, and the chances of being successful in a war. They simply do not seem to be particularly applicable to U.S.-UK relations. Nonetheless, the model does accurately predict American foreign policy vis-à-vis the United Kingdom on some of the other variables. For instance, in both the decade before World War II, and the decades since, American leadership regarding Britain has been moderate-acquiescent to moderate-pragmatic. The DPMP has accurately predicted that the United States either would acquiesce in the face of British growth or would accommodate the UK. Similarly, the threat from the UK in the 1930s and after World War II, if there was any threat at all, would have to be 
classified as low non-militarized. The typology accurately predicts that American foreign policy should be acquiescent in these circumstances.

\section{$\underline{\text { Russia/Soviet Union }}$}

In the case of Russia and the early Soviet Union, the DPMP performs very well. For the period of the nineteenth century, the model accurately predicts that the American government should largely do nothing or accommodate the Russians during the 1860s and 1870s. In addition, during the 1920s and 1930s, our model is correct; no preventive action was taken by the United States against Russia during this period.

The behavior of the Roosevelt administration vis-à-vis the Soviet Union during the 1930s is accurately predicted by the DPMP, though not the specifics of that behavior. Because the Soviet Union prior to the Second World War was not seen as a military threat, but an ideological threat, my model may be seen as accurately predicting that the U.S. would accommodate the Soviet Union.

The DPMP also does a good job of predicting actual American behavior in relation to the Soviet Union during the Cold War. During this period, political constraints were moderate for American leaders. Given this condition, the model once again performs well: predicting a mix of strategies including the use of incentives, coercion, and confrontational diplomacy. The DPMP accurately predicts that preventive action was likely, but that non-militarized preventive action might be preferred. Containment, as a form of non-militarized preventive action, was the preferred method of dealing with the Soviet Union after World War II. This, as predicted by the model, resulted in sustained coercive and confrontational diplomacy during the Cold War period. 


\section{Which Model_or Models_-Works Best?}

This is a difficult question to answer. In this chapter, the three models were briefly reviewed in an effort to sort out the merits of each. All three models attempt to present information that can be useful in trying to answer the grand question of when preventive action is likely to occur, and what form it is likely to take.

This dissertation has considered the decline of three major powers and their responses to rising challengers. None of the models - the Domestic Politics Model of Prevention, Mearsheimer's model of offensive realism, or Schweller's democratic peace model — accurately predict the three states' foreign policy in every instance examined in this dissertation. However, as shown in Table 7.1, the DPMP performs considerably better than the other two models. The offensive realism model, Schweller's model, and my model accurately predict the form preventive action is likely to take, one-third of the time, one-half of the time, and three-quarters of the time, respectively. In all fairness, the two alternative models used here were not originally designed for this type of prediction, and this may account for their relatively poor showing. Nonetheless, the high rate of accurate prediction of the DPMP suggests that domestic factors play a large part in determining what if any preventive action a state is likely to take. 
Table 7.1 Summation of Model Performance

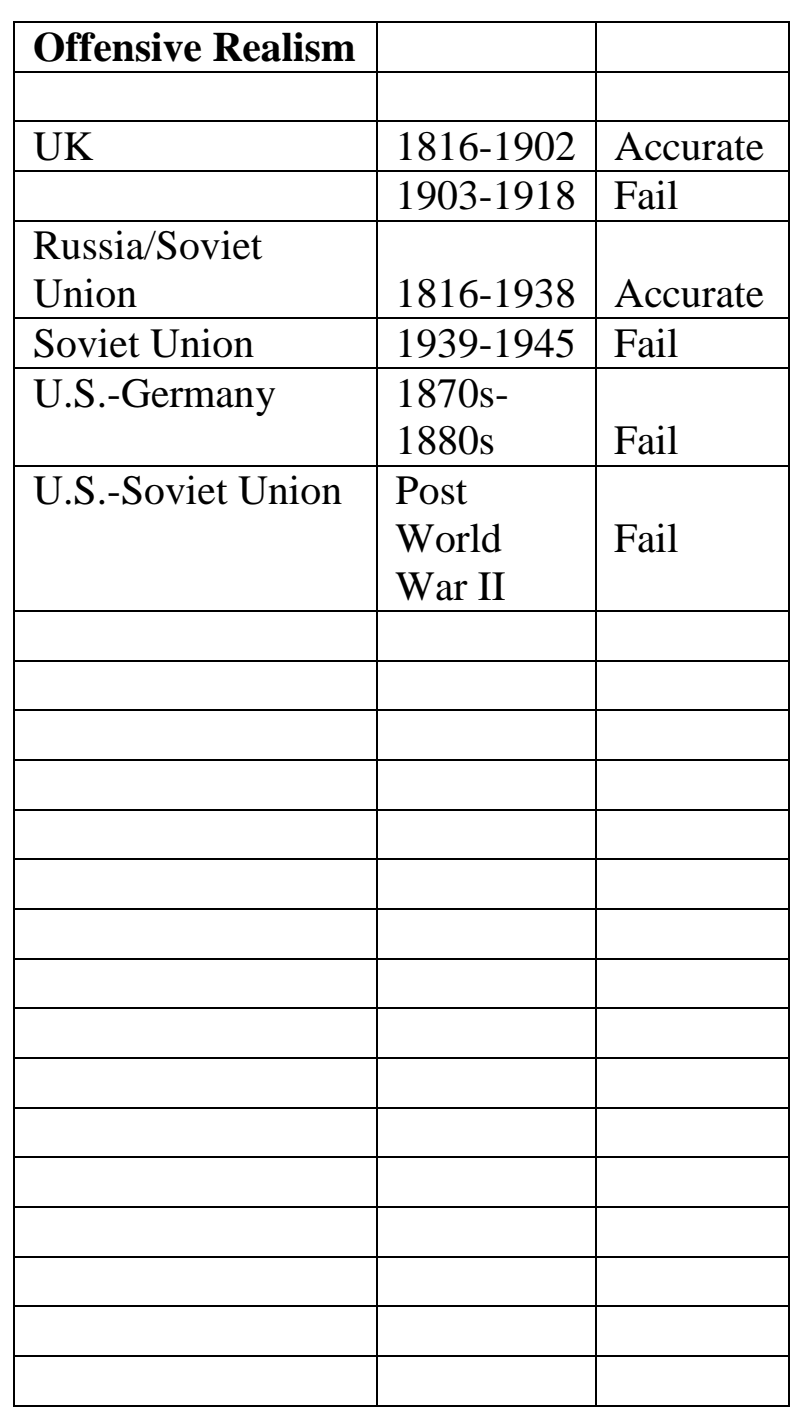

\begin{tabular}{|l|l|l|}
\hline $\begin{array}{l}\text { Democratic } \\
\text { Peace }\end{array}$ & & \\
\hline & & \\
\hline UK & $1816-1879$ & Fail \\
\hline UK-Japan & $1860-1904$ & Fail \\
\hline UK-U.S. & $1880-1906$ & Accurate \\
\hline UK-Germany & $1897-1904$ & Accurate \\
\hline UK-Russia & $1897-1904$ & Accurate \\
\hline Russia & $1816-1879$ & Accurate \\
\hline & $1880-1896$ & Fail \\
\hline & $1897-1902$ & Accurate \\
\hline Russia-Japan & $1903-1904$ & Fail \\
\hline $\begin{array}{l}\text { Russia/Soviet } \\
\text { Union-Japan }\end{array}$ & $1906-1918$ & Fail \\
\hline Soviet Union & $1932-1946$ & Fail \\
\hline U.S.-Japan & $1863-1867$ & Fail \\
\hline U.S.-Russia & $1863-1867$ & Fail \\
\hline U.S.-Germany & $1868-1877$ & Fail \\
\hline U.S.-Japan & $1868-1877$ & Accurate \\
\hline U.S.-Russia & $1868-1888$ & Fail \\
\hline U.S.-Germany & $1878-1888$ & Accurate \\
\hline U.S.-Japan & $1878-1888$ & Fail \\
\hline U.S.-UK & $1920-1932$ & Accurate \\
\hline U.S.-Germany & $1920-1932$ & Fail \\
\hline U.S.-Japan & $1920-1932$ & Fail \\
\hline $\begin{array}{l}\text { U.S.-Soviet } \\
\text { Union }\end{array}$ & $1920-1932$ & Fail \\
\hline U.S.-Germany & $1933-1939$ & Accurate \\
\hline
\end{tabular}

\begin{tabular}{|c|c|c|}
\hline $\begin{array}{l}\text { Democratic } \\
\text { Peace }\end{array}$ & & \\
\hline U.S.-Japan & 1933-1939 & Accurate \\
\hline $\begin{array}{l}\text { U.S.-Soviet } \\
\text { Union }\end{array}$ & 1933-1939 & Fail \\
\hline U.S.-UK & 1933-1939 & Accurate \\
\hline U.S. & 1946-1951 & Accurate \\
\hline U.S. & 1953-1970 & Accurate \\
\hline U.S. & 1971-1996 & Accurate \\
\hline & & \\
\hline & & \\
\hline & & \\
\hline & & \\
\hline & & \\
\hline & & \\
\hline & & \\
\hline & & \\
\hline & & \\
\hline & & \\
\hline & & \\
\hline & & \\
\hline & & \\
\hline & & \\
\hline & & \\
\hline
\end{tabular}




\begin{tabular}{|l|l|l|}
\hline $\begin{array}{l}\text { Domestic } \\
\text { Factors }\end{array}$ & & \\
\hline $\begin{array}{l}\text { UK (Power } \\
\text { Constraints) }\end{array}$ & $1895-1905$ & Accurate \\
\hline $\begin{array}{l}\text { UK (PA } \\
\text { Elements) }\end{array}$ & $1895-1905$ & Accurate \\
\hline $\begin{array}{l}\text { UK (Ruler } \\
\text { Beliefs) }\end{array}$ & $1895-1905$ & Accurate \\
\hline $\begin{array}{l}\text { UK (Nature of } \\
\text { Threat) }\end{array}$ & $1895-1905$ & Fail \\
\hline $\begin{array}{l}\text { UK } \\
\text { (Likelihood of } \\
\text { Conflict) }\end{array}$ & $1895-1905$ & Fail \\
\hline $\begin{array}{l}\text { UK (Cost of } \\
\text { War) }\end{array}$ & $1895-1905$ & Accurate \\
\hline $\begin{array}{l}\text { UK (Expected } \\
\text { Cost of Future } \\
\text { War) }\end{array}$ & $1895-1905$ & Accurate \\
\hline $\begin{array}{l}\text { UK (Chance } \\
\text { of Winning } \\
\text { War) }\end{array}$ & $1895-1905$ & Accurate \\
\hline $\begin{array}{l}\text { UK (Status } \\
\text { Quo) }\end{array}$ & $1895-1905$ & Fail \\
\hline $\begin{array}{l}\text { Russia/Soviet } \\
\text { Union (Power } \\
\text { Constraints) }\end{array}$ & $1816-1914$ & Accurate \\
\hline $\begin{array}{l}\text { Russia/Soviet } \\
\text { Union (PA } \\
\text { Elements) }\end{array}$ & $1816-195$ & Accurate \\
\hline
\end{tabular}

\begin{tabular}{|l|l|l|}
\hline $\begin{array}{l}\text { Domestic } \\
\text { Factors }\end{array}$ & & \\
\hline & & \\
\hline $\begin{array}{l}\text { Russia/Soviet } \\
\text { Union (Ruler } \\
\text { Beliefs) }\end{array}$ & $1816-1946$ & Accurate \\
\hline $\begin{array}{l}\text { Russia/Soviet } \\
\text { Union (Nature } \\
\text { of Threat) }\end{array}$ & $1816-1938$ & Fail \\
\hline $\begin{array}{l}\text { Russia/Soviet } \\
\text { Union } \\
\text { (Likelihood of } \\
\text { Conflict) }\end{array}$ & $1816-1938$ & Accurate \\
\hline $\begin{array}{l}\text { Russia/Soviet } \\
\text { Union (Cost of } \\
\text { War) }\end{array}$ & $1816-1938$ & Accurate \\
\hline $\begin{array}{l}\text { Russia/Soviet } \\
\text { Union-Japan } \\
\text { (Cost of War) }\end{array}$ & 1904 & Fail \\
\hline $\begin{array}{l}\text { Russia/Soviet } \\
\text { Union } \\
\text { (Expected Cost } \\
\text { of Future War) }\end{array}$ & $1816-1938$ & Fail \\
\hline $\begin{array}{l}\text { Russia/Soviet } \\
\text { Union (Chance } \\
\text { of Winning } \\
\text { War) }\end{array}$ & & \\
\hline
\end{tabular}

\begin{tabular}{|l|l|l|}
\hline $\begin{array}{l}\text { Domestic } \\
\text { Factors }\end{array}$ & & \\
\hline & & \\
\hline $\begin{array}{l}\text { Russia/Soviet } \\
\text { Union (Status } \\
\text { Quo) }\end{array}$ & $1816-1938$ & Accurate \\
\hline $\begin{array}{l}\text { U.S.- } \\
\text { Russia/Soviet } \\
\text { Union (Power } \\
\text { Constraints) }\end{array}$ & $1863-1970$ & Accurate \\
\hline $\begin{array}{l}\text { U.S.-Germany } \\
\text { (Power } \\
\text { Constraints) }\end{array}$ & $1870 s-$ & \\
\hline $\begin{array}{l}\text { U.S.-Japan } \\
\text { (Power }\end{array}$ & $1930 \mathrm{~s}$ & Fail \\
Constraints) & $1865-1939$ & Accurate \\
\hline $\begin{array}{l}\text { U.S.-Japan } \\
\text { (Power }\end{array}$ & & \\
Constraints) & $1952-1982$ & N/A \\
\hline $\begin{array}{l}\text { U.S.-UK } \\
\text { (Power }\end{array}$ & & \\
Constraints) & $1946-1996$ & N/A \\
\hline $\begin{array}{l}\text { U.S.- } \\
\text { Russia/Soviet } \\
\text { Union (PA } \\
\text { Elements) }\end{array}$ & & \\
\hline $\begin{array}{l}\text { U.S.-Germany } \\
\text { (PA Elements) }\end{array}$ & 1870 s- & Fail \\
\hline
\end{tabular}




\begin{tabular}{|c|c|c|}
\hline $\begin{array}{l}\text { Domestic } \\
\text { Factors }\end{array}$ & & \\
\hline $\begin{array}{l}\text { U.S.-Germany } \\
\text { (PA Elements) }\end{array}$ & 1933-1939 & Accurate \\
\hline $\begin{array}{l}\text { U.S.-Japan (PA } \\
\text { Elements) }\end{array}$ & 1930-1939 & Accurate \\
\hline $\begin{array}{l}\text { U.S.-Japan (PA } \\
\text { Elements) }\end{array}$ & 1952-1982 & Fail-N/A \\
\hline $\begin{array}{l}\text { U.S.-UK (PA } \\
\text { Elements) }\end{array}$ & 1946-1996 & $\begin{array}{l}\text { Accurate } \\
\text { N/A }\end{array}$ \\
\hline $\begin{array}{l}\text { U.S.-Russia } \\
\text { (Ruler Beliefs) }\end{array}$ & $\begin{array}{l}1860 \mathrm{~s}- \\
1870 \mathrm{~s} \\
\end{array}$ & Accurate \\
\hline $\begin{array}{l}\text { U.S.-Soviet } \\
\text { Union (Ruler } \\
\text { Beliefs) }\end{array}$ & $1925-1938$ & Accurate \\
\hline $\begin{array}{l}\text { U.S.-Soviet } \\
\text { Union (Ruler } \\
\text { Beliefs) }\end{array}$ & 1946-1970 & Accurate \\
\hline $\begin{array}{l}\text { U.S.-Germany } \\
\text { (Ruler Beliefs) }\end{array}$ & $\begin{array}{l}\text { 1870s- } \\
1880 \mathrm{~s}\end{array}$ & Fail \\
\hline $\begin{array}{l}\text { U.S.-Germany } \\
\text { (Ruler Beliefs) }\end{array}$ & 1920-1939 & Accurate \\
\hline $\begin{array}{l}\text { U.S.-Japan } \\
\text { (Ruler Beliefs) }\end{array}$ & $1865-1876$ & Accurate \\
\hline $\begin{array}{l}\text { U.S.-Japan } \\
\text { (Ruler Beliefs) }\end{array}$ & 1930-1939 & Accurate \\
\hline $\begin{array}{l}\text { U.S.-Japan } \\
\text { (Ruler Beliefs) }\end{array}$ & 1952-1982 & Accurate \\
\hline
\end{tabular}

\begin{tabular}{|l|l|l|}
\hline $\begin{array}{l}\text { Domestic } \\
\text { Factors }\end{array}$ & & \\
\hline & & \\
\hline $\begin{array}{l}\text { U.S.-Soviet } \\
\text { Union (Nature of } \\
\text { Threat) }\end{array}$ & $1925-1938$ & Accurate \\
\hline $\begin{array}{l}\text { U.S.-Soviet } \\
\text { Union (Nature of } \\
\text { Threat) }\end{array}$ & $1946-1970$ & Accurate \\
\hline $\begin{array}{l}\text { U.S.-Germany } \\
\text { (Nature of } \\
\text { Threat) }\end{array}$ & 1870 s- & \\
\hline $\begin{array}{l}\text { U.S.-Germany } \\
\text { (Nature of } \\
\text { Threat) }\end{array}$ & $1880 \mathrm{~s}$ & Accurate \\
\hline $\begin{array}{l}\text { U.S.-Japan } \\
\text { (Nature of } \\
\text { Threat) }\end{array}$ & $1860 s-$ & Accurate \\
\hline $\begin{array}{l}\text { U.S.-Japan } \\
\text { (Nature of } \\
\text { Threat) }\end{array}$ & 1870 s & Accurate \\
\hline $\begin{array}{l}\text { U.S.-Japan } \\
\text { (Nature of } \\
\text { Threat) }\end{array}$ & $1930-1939$ & Fail \\
\hline $\begin{array}{l}\text { U.S.-UK (Nature } \\
\text { of Threat) }\end{array}$ & $1930-1939$ & Accurate \\
\hline $\begin{array}{l}\text { U.S.-Russia } \\
\text { (Likelihood of } \\
\text { Conflict) }\end{array}$ & $1946-1996$ & Accurate \\
\hline
\end{tabular}




\begin{tabular}{|l|l|l|}
\hline $\begin{array}{l}\text { Domestic } \\
\text { Factors }\end{array}$ & & \\
\hline & & \\
\hline $\begin{array}{l}\text { U.S.-Soviet } \\
\text { Union } \\
\text { (Likelihood of } \\
\text { Conflict) }\end{array}$ & $1925-1938$ & Accurate \\
\hline $\begin{array}{l}\text { U.S.-Soviet } \\
\text { Union } \\
\text { (Likelihood of } \\
\text { Conflict) }\end{array}$ & $1946-1970$ & Accurate \\
\hline $\begin{array}{l}\text { U.S.-Germany } \\
\text { (Likelihood of } \\
\text { Conflict) }\end{array}$ & 1870 s- & \\
\hline $\begin{array}{l}\text { U.S.-Germany } \\
\text { (Likelihood of } \\
\text { Conflict) }\end{array}$ & 1880 s & Accurate \\
\hline $\begin{array}{l}\text { U.S.-Japan } \\
\text { (Likelihood of } \\
\text { Conflict) }\end{array}$ & $1933-1939$ & Accurate \\
\hline $\begin{array}{l}\text { U.S.-UK } \\
\text { (Likelihood of } \\
\text { Conflict) }\end{array}$ & $1930-1939$ & \\
\hline $\begin{array}{l}\text { U.S.-Soviet } \\
\text { Union (Cost of } \\
\text { War) }\end{array}$ & $1946-1939$ & Accurate \\
\hline $\begin{array}{l}\text { U.S.-Germany } \\
\text { (Cost of War) }\end{array}$ & $1973-1988-1989$ & Accurate \\
\hline $\begin{array}{l}\text { U.S.-Japan (Cost } \\
\text { of War) }\end{array}$ & $1930-1939$ & Accurate \\
\hline
\end{tabular}

The following shows the ratio of accurate predictions for each model:

Offensive Realism: .33 (2/6)

Schweller's Democratic Peace Model: .48 (14/29)

Domestic Factors Model: .78 (51/65)

\begin{tabular}{|c|c|c|}
\hline $\begin{array}{l}\text { Domestic } \\
\text { Factors }\end{array}$ & & \\
\hline $\begin{array}{l}\text { U.S.-UK (Cost } \\
\text { of War) }\end{array}$ & $\begin{array}{l}1930-1939 \\
1946-1996 \\
\end{array}$ & N/A \\
\hline $\begin{array}{l}\text { U.S.-Soviet } \\
\text { Union (Expected } \\
\text { Cost of Future } \\
\text { War) }\end{array}$ & 1946-1970 & Accurate \\
\hline $\begin{array}{l}\text { U.S.-Germany } \\
\text { (Expected Cost } \\
\text { of Future War) }\end{array}$ & $\begin{array}{l}1873-1888 \\
1933-1939 \\
\end{array}$ & Accurate \\
\hline $\begin{array}{l}\text { U.S.-Japan } \\
\text { (Expected Cost } \\
\text { of Future War) }\end{array}$ & 1930-1939 & Accurate \\
\hline $\begin{array}{l}\text { U.S.-Soviet } \\
\text { Union (Chance } \\
\text { of Winning War) }\end{array}$ & 1946-1970 & Accurate \\
\hline $\begin{array}{l}\text { U.S.-Germany } \\
\text { (Chance of } \\
\text { Winning War) }\end{array}$ & 1873-1888 & Accurate \\
\hline $\begin{array}{l}\text { U.S.Japan } \\
\text { (Chance of } \\
\text { Winning War) }\end{array}$ & 1930-1939 & Accurate \\
\hline $\begin{array}{l}\text { U.S.-Soviet } \\
\text { Union (Status } \\
\text { Quo) }\end{array}$ & 1946-1970 & Accurate \\
\hline $\begin{array}{l}\text { U.S.-Germany } \\
\text { (Status Quo) }\end{array}$ & $\begin{array}{l}1873-1888 \\
1933-1939 \\
\end{array}$ & Accurate \\
\hline $\begin{array}{l}\text { U.S.-Japan } \\
\text { (Status Quo) }\end{array}$ & $1930-1938$ & Accurate \\
\hline $\begin{array}{l}\text { U.S.-Japan } \\
\text { (Status Quo) }\end{array}$ & 1939 & Fail \\
\hline
\end{tabular}




\section{$\underline{\text { Implications }}$}

What does this imply for the future of the study of preventive action? First, it indicates the importance of further study, and the disaggregating of causal mechanisms and key variables that drive preventive action decisions. Determining when states are likely to engage in preventive action is difficult enough, but predicting what form that preventive action is likely to take further complicates the issue. The DPMP developed here is a good start.

This study also revealed the importance of looking inside the black box of the state and understanding the preventive motivation of various actors and decision makers within the state. Understanding the perception of key decision makers is essential in successfully determining the direction of national strategy. Decision makers' perceptions about the nature of the threat posed by a rising challenger, and the concern about a worsening status quo seem particularly significant. Also of importance in understanding the calculations that go into preventive action decisions is the concern about the cost of war now versus the cost of war in the future. Much of this, of course, hinges on the perceived likelihood of conflict.

Finally, this study reveals that these different variables are very difficult to separate. They are intertwined, especially variables such as the costs of future wars and the likelihood of winning future wars. George and Bennett suggest that the case study method is particularly useful in specifying and measuring complex qualitative variables. Complex causal relations involve interacting causal variables that are not independent of each other. This is important in explaining instances when preventive action does not occur, even though some criteria suggests a particular form of preventive action is likely. 
For example, in any given case, the military status quo might be deteriorating-which would suggest some form of militarized preventive action is likely. However, if the costs of militarized preventive action are already high, the country might shy away from militarized preventive action and towards non-militarized preventive action. Because of the complexity of these causal mechanisms, this study is necessarily concerned with the probability of a given form of preventive action. It might be possible, in future iterations of this research, to combine some of these variables and to dissect others. Nonetheless, this dissertation has shown a path to future research of preventive action.

\section{Conclusion}

This dissertation has sought to answer the basic question, "When is preventive action likely to occur, and what form is it likely to take?" In the examinations of internal power constraints, domestic political constraints, and ruler belief systems, it has become apparent that perceptions and domestic politics are very influential in determining the

probability of preventive action. This is an important finding since it provides the crucial variables and causal mechanisms that go into the preventive action decision-making process.

Also of interest in this research are its implications regarding tangential fields of study. For example, prospect theory suggests that states are risk acceptant when it comes to possible losses - whether those losses are something tangible such as territory or whether they are less tangible such as international ranking or prestige—and states will likely engage in preventive action to avert those losses. What this research shows is that leaders make calculations based on a variety of variables, and quite often nations decide 
they are better off not taking any action at all; the United Kingdom and the Soviet Union provide clear examples. While not disproving prospect theory, findings like these suggest that prospect theory needs to be examined more closely.

This research has also called into question one of the issues raised earlier in this dissertation. Charles Kupchan has suggested that relatively declining states have allowed rising challengers to surpass them, even though elites have a good understanding of the balance of power. ${ }^{11}$ I argued in chapter three that if it were true that elites had an understanding that the balance of power was shifting against their state, they would not voluntarily allow a rising challenger to eclipse their state. This research has shown that repeatedly, decision makers have actually allowed this to occur. The answer usually lies in the elites' perceptions of threat posed by the rising challenger or the possibility of a future change in the trend that will ultimately put their state back in a superior position. Both of these are important findings.

Another important finding of this research is that outbreaks of preventive general war, at least among great powers, are exceedingly rare. More research is needed in this area, but it seems that general preventive war against a challenger-who is seen as somewhat equal or possibly becoming equal in power-is not a good option for the dominant declining power. I would suggest that this calculus will not hold for preventive action against states that are far from equal with the dominant declining power. This could be a fascinating area of study in the future.

As I was concluding the final substantive chapter of this project, I began to think about ways in which the DPMP could be improved in future iterations or expanded

\footnotetext{
${ }^{11}$ Charles A. Kupchan, The Vulnerability of Empire, ed. Robert J. Art, Robert Jervis, and Stephen M. Walt, Cornell Studies in Security Affairs (Ithaca, New York: Cornell University Press, 1994), fn. 22, 15-16, 36.
} 
beyond the current parameters. One of the limitations of this project was a self-imposed one: I wanted to have a systematic way of picking my cases, or at least have a common set of parameters to make my cases as comparable as possible. Because of this decision, I limited my cases to ones that I could objectively (as much as possible) determine which states were rising and which states were declining. I chose the Composite Index of National Capability (CINC) score as the barometer for rising and declining power. While I believe this accomplished the goal of creating a systematic method for looking at my cases, it also proved very limiting. One of the first limitations this placed on this project was restricting my cases to those covered in the Correlates of War database, meaning I could only look at the years 1816 to 2001 . Unfortunately, this meant that some cases that might be of interest were necessarily omitted. For example, one interesting case would have been Great Britain's early reactions to the rise of the United States even before the American Revolution. Robert Kagan argues that perceptive Britons like James Harrington, William Burke, and Adam Smith understood that the colonies would eventually rise up against the mother country. ${ }^{12}$ British, Spanish, and French containment of the United States during the 1780s would also be of interest. ${ }^{13}$

I am also unsure that using the CINC score is necessarily the best measurement available for understanding leadership perceptions of the rise of adversaries. Using this score is certainly an objective way to look at the rise and fall of nations from a distance, but it might not capture the important perceptual shifts that occur at the time. However, having said that, developing a reliable index of leader perceptions during times of crisis was well beyond the scope of this research project.

\footnotetext{
${ }^{12}$ Robert Kagan, Dangerous Nation: America's Place in the World from Its Earliest Days to the Dawn of the Twentieth Century (New York: Alfred A. Knopf, 2006), 30-38.

${ }^{13}$ Ibid., 53-56.
} 
Despite some of these concerns, the research presented in this dissertation has provided new insights into the decision making process that can lead to preventive action. We have gotten closer to being able to answer the question of whether preventive action is likely to occur, and what form it is likely to take. The causal mechanisms, concepts, and variables developed here are instructive when determining what type of response declining dominant powers are likely to have vis-à-vis rising challengers. Furthermore, understanding the interaction of the various parts of the DPMP helps us understand the complexities behind these processes. Now that we have moved beyond the simple dichotomous view of relations between declining states and rising challengers, it will be possible to further refine the model of preventive action and develop more concise causal mechanisms. Ultimately, we will be able to gain a better understanding of the preventive motivation and the variables that drive leaders to make the decision they do. 


\section{Bibliography}

Brown, Benjamin H. The Tariff Reform Movement in Great Britain 1881-1895. New York: Colombia University Press, 1943.

Bush, George W. "The National Security Strategy of the United States." 2002.

Cohen, Warren I. America in the Age of Soviet Power, 1945-1991, edited by Warren I. Cohen. Vol. IV of The Cambridge History of American Foreign Relations. New York: Cambridge University Press, 1993.

Copeland, Dale C. The Origins of Major War. Edited by Robert J. Art, Robert Jervis and Stephen M. Walt, Cornell Studies in Security Affairs. Ithaca, New York: Cornell University Press, 2000 .

Correlates of War. National Material Capabilities v. 3.02. http://www.correlatesofwar.org

Davies, Norman. Europe: A History. New York: Harper Perennial, 1996.

DiCicco, Jonathan M. and Jack S. Levy. "The Power Transition Research Program.” Progress in International Relations Theory: Appraising the Field, edited by Colin Elman and Miriam Fendius Elman. The MIT Press, 2003.

Dictionary of World History. New York: Oxford University Press, 2000.

Doran, Charles F. "Confronting the Principles of the Power Cycle: Changing Systems Structure, Expectations, and War." Handbook of War Studies II, edited by Manus I. Midlarsky. Ann Arbor: The University of Michigan Press, 2000.

Emmerson, John K. and Harrison M. Holland. The Eagle and the Rising Sun: America and Japan in the Twentieth Century, edited by Miriam Miller. Stanford, California: Stanford Alumni Association, 1987.

Ferguson, Niall. Colossus: The Price of America's Empire. New York: The Penguin Press, 2004.

- Empire: The Rise and Demise of the British World Order and the Lessons for Global Power. New York: Basic Books, 2002.

Friedberg, Aaron L. The Weary Titan: Britain and the Experience of Relative Decline, 1895 1905. Princeton, New Jersey: Princeton University Press, 1988.

Freeze, Gregory L. "Reform and Counter Reform 1855-1890." In Russia: A History, edited by Gregory L. Freeze, 523. New York: Oxford University Press, 2002.

Fuller, Thomas. The History of the Holy War. London: William Pickering, 1840. 
Fuller, William C., Jr. "The Great Fatherland War and Late Stalinism 1941-1953." In Russia: A History, edited by Gregory L. Freeze, 523. New York: Oxford University Press, 2002.

Gacek, Christopher M. The Logic of Force: The Dilemma of Limited War in American Foreign Policy. New York: Columbia University Press, 1994.

Gaddis, John Lewis. Strategies of Containment: A Critical Appraisal of Postwar American National Security Policy. New York: Oxford University Press, 1982.

- The United States and the End of the Cold War: Implications, Reconsiderations, Provocations. New York: Oxford University Press, 1992.

Gilpin, Robert. War \& Change in World Politics. New York: Cambridge University Press, 1981.

Geller, Daniel S. "Status Quo Orientation, Capabilities, and Patters of War Initiation in Dyadic Rivalries." Conflict Management and Peace Science 18, no. 1, 2000.

George, Alexander L., and Andrew Bennett. Case Studies and Theory Development in the Social Sciences, BCSIA Studies in International Security. Cambridge, Massachusetts: MIT Press, 2005.

George, Alexander L., and Timothy J. McKeown. "Case Studies and Theories of Organizational Decision Making." In Advances in Information Processing in Organizations, 21-58. Greenwich, Conn.: JAI Press, 1985.

Hagan, Joe D. "Domestic Political Regime Change and Foreign Policy Restructuring: A Framework for Comparative Analysis." In Foreign Policy Restructuring: How Governments Respond to Global Change, edited by Jerel A. Rosati, Joe D. Hagan and Martin W. Sampson, III, 138-63. Columbia, South Carolina: University of South Carolina Press, 1994.

_. "Domestic Political Systems and War Proneness." Mershon International Studies Review 38 (1994): 183-207.

—_. "Oppositions, Ruling Strategies, and the Domestic Road to War: Political Explanations of Foreign Policy and the Great Powers since 1815." Paper presented at the Annual Meeting of the International Studies Association, Montreal, Canada, March 17-20 2004.

Hinsely, F. H., ed. The Cambridge Modern History: Volume Xi Material Progress and WorldWide Problems 1870-1898. Edited by G. N. Clark, J. R. M. Butler, J. P. T. Bury and E. A. Benians. XIV vols. Vol. XI, The New Cambridge Modern History. London: Cambridge University Press, 1962.

Hunt, Michael S. Crises in U.S. Foreign Policy. New Haven and London: Yale University Press, 1996. 
Husband, William B. "The New Economic Policy (NEP) and the Revolutionary Experiment 1921-1929." In Russia: A History, edited by Gregory L. Freeze, 523. New York: Oxford University Press, 2002.

Iriye, Akira. The Globalizing of America, 1913-1945, edited by Warren I. Cohen. Vol. III of The Cambridge History of American Foreign Relations. New York: Cambridge University Press, 1993.

Kadera, Kelly M. The Power-Conflict Story: A Dynamic Model of Interstate Rivalry. Ann Arbor: The University of Michigan Press, 2001.

Kagan, Robert. Dangerous Nation: America's Place in the World from Its Earliest Days to the Dawn of the Twentieth Century. New York: Alfred A. Knopf, 2006.

Kennedy, Paul. The Rise and Fall of the Great Powers. New York: Vintage Books, 1987.

Kim, Woosang and James D. Morrow. "When Do Power Shifts Lead to War?” American Journal of Political Science 36, no. 4, 1992.

King, Gary, Robert O. Keohane, and Sidney Verba. Designing Social Inquiry: Scientific Inference in Qualitative Research. Princeton, New Jersey: Princeton University Press, 1994.

Krasner, Stephen D. Defending the National Interest: Raw Materials Investment and U.S. Foreign Policy. Princeton, New Jersey: Princeton University Press, 1978.

Kugler, Jacek and A.F.K. Organski. "The Power Transition: A Retrospective and Prospective Evaluation. Handbook of War Studies, edited by Manus I. Midlarsky. Boston: Unwin Hyman, 1989.

Kugler, Jacek and Douglas Lemke, eds. Parity and War: Evaluations and Extensions of The War Ledger. Ann Arbor: The University of Michigan Press, 1996.

—. "The Power Transition Research Program: Assessing Theoretical and Empirical Advances." Handbook of War Studies II, edited by Manus I. Midlarsky. Ann Arbor: The University of Michigan Press, 2000.

Kupchan, Charles A. The Vulnerability of Empire. Edited by Robert J. Art, Robert Jervis and Stephen M. Walt, Cornell Studies in Security Affairs. Ithaca, New York: Cornell University Press, 1994.

—. The Vulnerability of Empire. Ithaca and London: Cornell University Press, 1994. 
LaFeber, Walter. The American Search for Opportunity, 1865-1913, edited by Warren I. Cohen. Vol. II of The Cambridge History of American Foreign Relations. New York: Cambridge University Press, 1993.

Lebow, Richard Ned. Between Peace and War: The Nature of International Crisis. Baltimore and London: The Johns Hopkins University Press, 1981.

—_. "Windows of Opportunity: Do States Jump Through Them?" International Security 9, no. $1,1984$.

Levy, Jack S. "Declining Power and the Preventive Motivation for War," World Politics 40, no. 1 (1987).

_. "Prospect Theory, Rational Choice, and International Relations." International Studies Quarterly 41 (1997): 87-112.

Levy, Jack S. and Joseph R. Gochal. "When Do Democracies Fight 'Preventive Wars'?: Theory and Evidence." Paper presented at the Annual Meeting of the International Studies Association, Montreal, Canada, March 17-20 2004.

Lowe, Peter. The Origins of the Korean War. Edited by Harry Hearder, Origins of Modern Wars. New York: Longman, 1986.

Lund, Michael S. Preventing Violent Conflicts: A Strategy for Preventive Diplomacy. Washington D.C.: United States Institute of Peace Press, 1996.

Mallet, Bernard. British Budgets 1877-88 to 1912-13. London: Macmillan and Co., Limited, 1913.

Maoz, Zeev. Paths to Conflict. Boulder, CO: Westview, 1982.

Mead, Walter Russell. Special Providence: American Foreign Policy and How It Changed the World. New York: Routledge, 2002.

Mearsheimer, John J. The Tragedy of Great Power Politics. New York: W. W. Norton \& Company, 2001.

Modelski, George and William R. Thompson. "Long Cycles and Global War." Handbook of War Studies, edited by Manus I. Midlarsky. Boston: Unwin Hyman, 1989.

Morgan, Patrick M. Deterrence Now. New York: Cambridge University Press, 2003.

Morgenthau, Hans J. Politics Among Nations: The Struggle for Power and Peace, $4^{\text {th }}$ ed. New York: Knopf, 1967. 
Niou, Emerson M. S. and Peter C. Ordeshook. "Preventive War and the Balance of Power: A Game Theoretic Approach." Journal of Conflict Resolution 31, September, 1987.

Organski, A.F.K. World Politics, $2^{\text {nd }}$ ed. New York: Knopf, 1968.

Organski, A.F.K. and Jacek Kugler. The War Ledger. Chicago and London: The University of Chicago Press, 1980.

. "The Costs of Major Wars: The Phoenix Factor." The Scientific Study of Peace and War: A Text Reader, editors John A. Vasquez and Marie T. Henehan. Lanham: Lexington Books, 1999.

Orlovsky, Daniel. "Russia in War and Revolution 1914-1921." In Russia: A History, edited by Gregory L. Freeze, 523. Oxford: Oxford University Press, 2002.

Otte, T.G., ed. The Makers of British Foreign Policy: From Pitt to Thatcher. London: Palgrave, 2002.

Oxford English Dictionary Online. http://dictionary.oed.com

Perkins, Bradford. The Creation of a Republican Empire, 1776-1865, edited by Waren I. Cohen. Vol. I of The Cambridge History of American Foreign Relations. New York: Cambridge University Press, 1995.

Polity IV Project: Political Regime Characteristics and Transitions, 1800-2007. Monty G. Marshall, Director. http://www.systemicpeace.org/polity/polity4.htm

Ransel, David L. "Pre-Reform Russia 1801-1855." In Russia: A History, edited by Gregory L. Freeze, 523. New York: Oxford University Press, 2002.

Rubin, Barnett R., ed. Cases and Strategies for Preventive Action. New York: The Century Foundation Press, 1998.

Sagan, Scott D., and Kenneth N. Waltz. The Spread of Nuclear Weapons: A Debate. New York and London: W.W. Norton \& Company, 1995.

Schroeder, Paul W. The Transformation of European Politics 1763 - 1848. Edited by Lord Bullock and William Deakin, Oxford History of Modern Europe. New York: Oxford University Press, Inc., 1994.

Schweller, Randall L. "Domestic Structure and Preventive War: Are Democracies More Pacific?" World Politics 44, no. 2 (1992): 235-69.

Seton-Watson, Hugh. The Russian Empire 1801-1917. Edited by Alan Bullock and F. W. D. Deakin, Oxford History of Modern Europe. Oxford: The Clarendon Press, 1967. 
Siegelbaum, Lewis. "Building Stalinism 1929-1941." In Russia: A History, edited by Gregory L. Freeze, 523. New York: Oxford University Press, 2002.

Snyder, Jack. The Ideology of the Offensive: Military Decision Making and the Disasters of 1914. Edited by Robert Jervis, Robert J. Art and Stephen M. Walt, Cornell Studies in Security Affairs. Ithaca, New York: Cornell University Press, 1984.

—. "Perceptions of the Security Dilemma in 1914." Psychology and Deterrence, edited by Robert Jervis, Richard Ned Lebow, and Janice Gross Stein. Baltimore: The Johns Hopkins University Press, 1985.

-. Myths of Empire: Domestic Politics and International Ambition. Edited by Robert Jervis, Robert J. Art and Stephen M. Walt, Cornell Studies in Security Affairs. Ithaca, New York: Cornell University Press, 1991.

Strassler, Robert B., ed. The Landmark Thucydides: A Comprehensive Guide to the Peloponnesian War. New York: Touchstone, 1996.

Tammen, Ronald L., et al. Power Transitions: Strategies for the $21^{\text {st }}$ Century. New York: Chatham House Publishers, 2000.

Taylor, A.J.P. The Struggle for Mastery in Europe 1848-1918. New York: Oxford University Press, 1954.

Vagts, Alfred. Defense and Diplomacy: The Soldier and the Conduct of Foreign Relations. New York: King's Crown Press, 1956.

Van Evera, Stephen. "The Cult of the Offensive and the Origins of World War I." International Security 9, Summer, 1984.

- Causes of War: Power and the Roots of Conflict. Ithaca and London: Cornell University Press, 1999.

- Methods for Students of Political Science. Ithaca, NY: Cornell University Press, 1997.

Vasquez, John A. The War Puzzle, Cambridge Studies in International Relations. New York: Cambridge University Press, 1993.

Waltz, Kenneth N. "The Emerging Structure of International Politics." International Security 18, no. 2 (1993): 44-79.

Ward, A.W., and G.P. Gooch. The Cambridge History of British Foreign Policy 1783-1919. 3 vols. Vol. III. New York: The Macmillan Company, 1922.

Williams, E. E. Made in Germany. Sussex, England: The Harvester Press, 1973. 
Zelnik, Reginald E. "Revolutionary Russia 1890-1914." In Russia: A History, edited by Gregory L. Freeze, 523. New York: Oxford University Press, 2002. 
Appendix A: The Decision Making Process in the Domestic Politics Model of Prevention (DPMP)

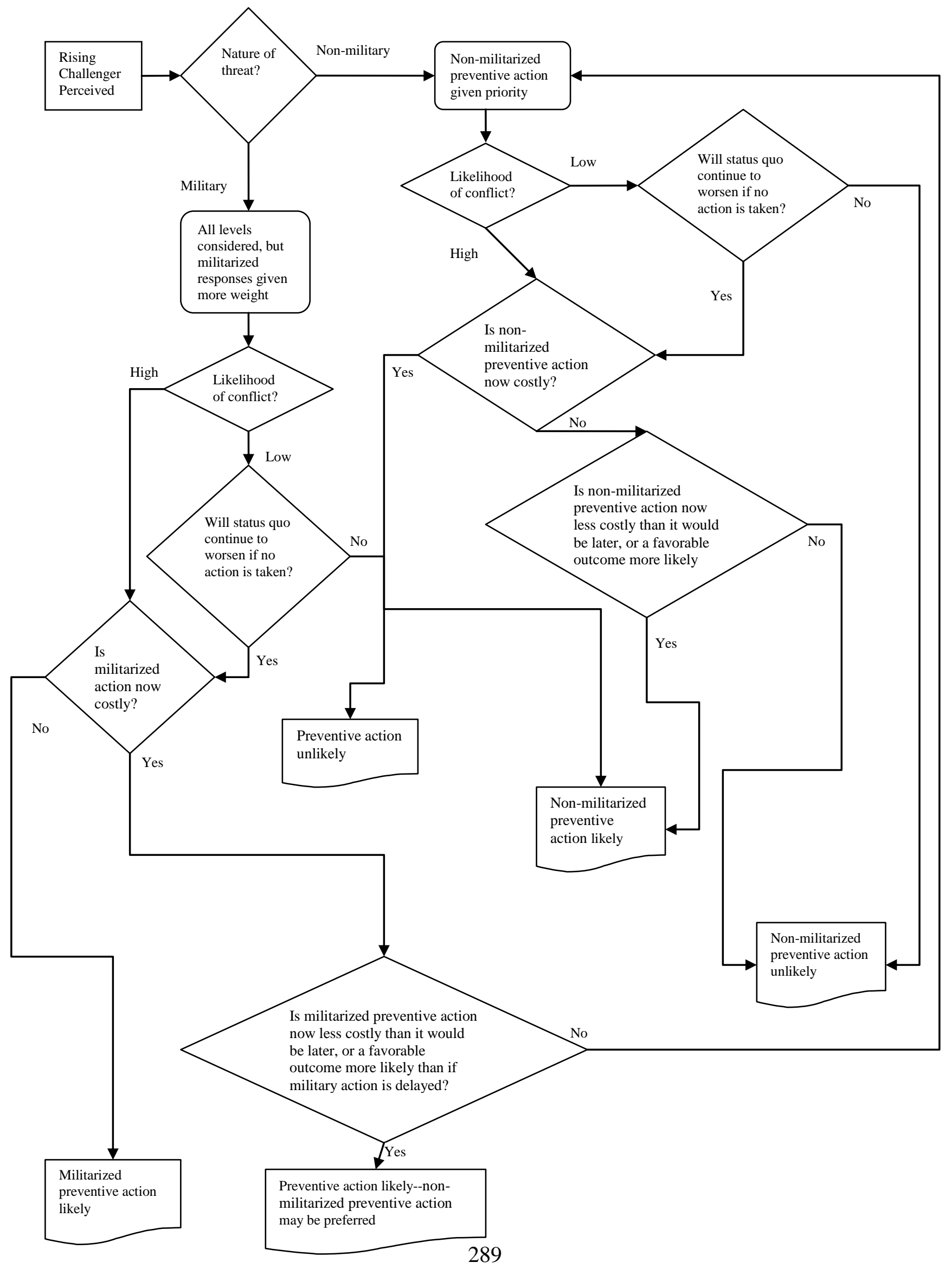


Appendix A: The Decision Making Process in the Domestic Politics Model of Prevention (DPMP) UK-U.S. Military Threat

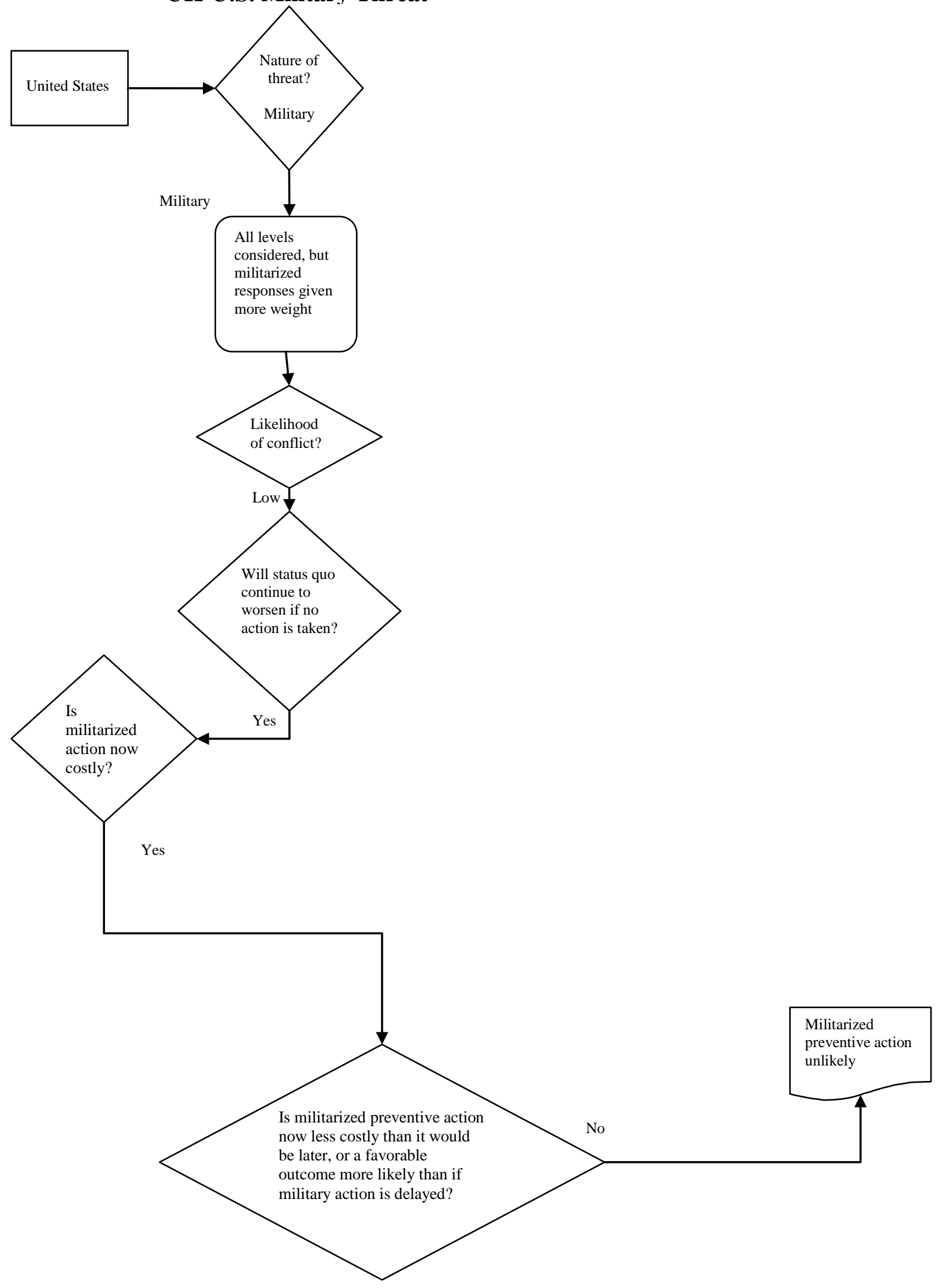


Appendix A: The Decision Making Process in the Domestic Politics Model of Prevention (DPMP)

UK-U.S. Economic Threat

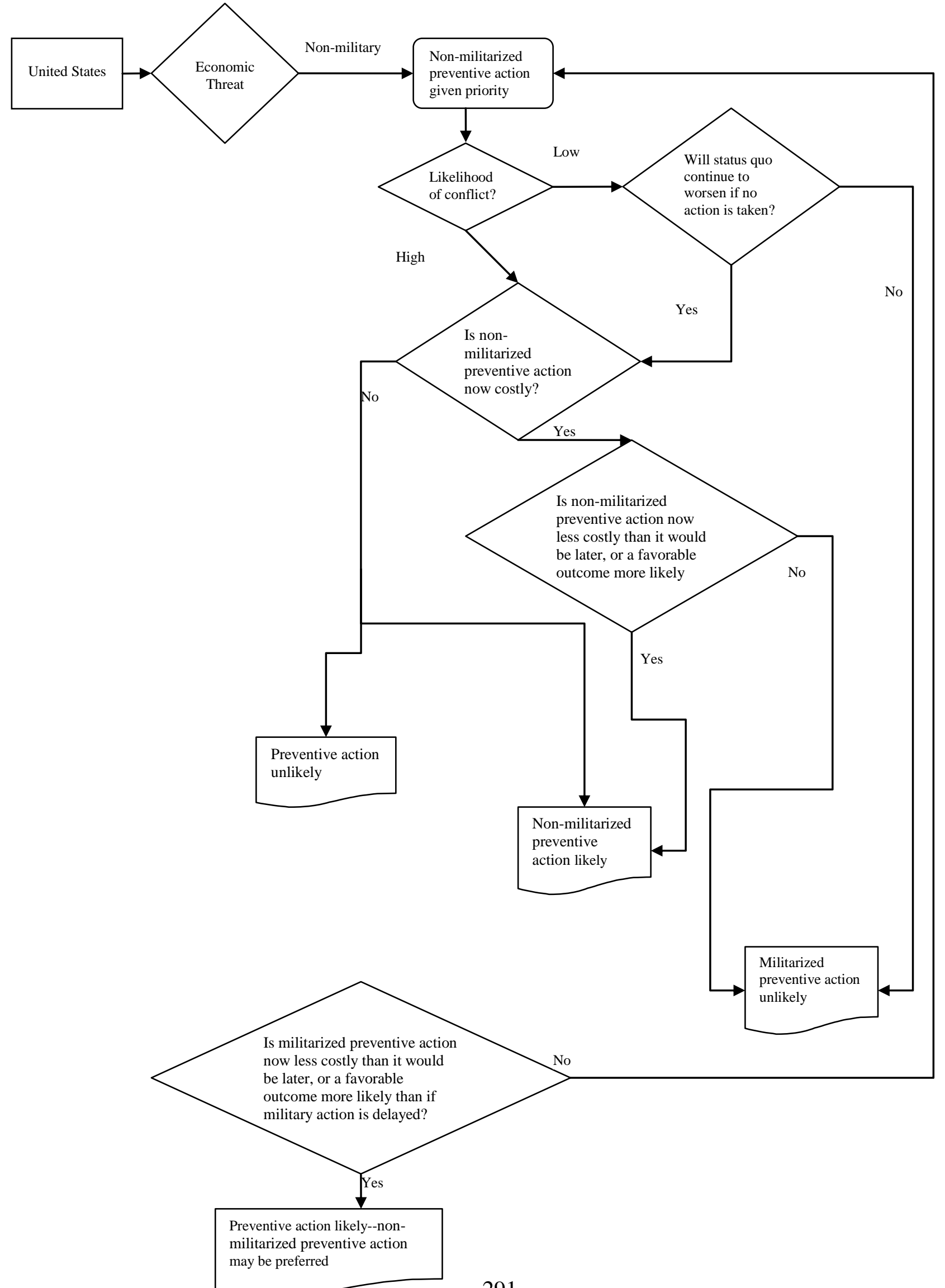


Appendix A: The Decision Making Process in the Domestic Politics Model of Prevention (DPMP)

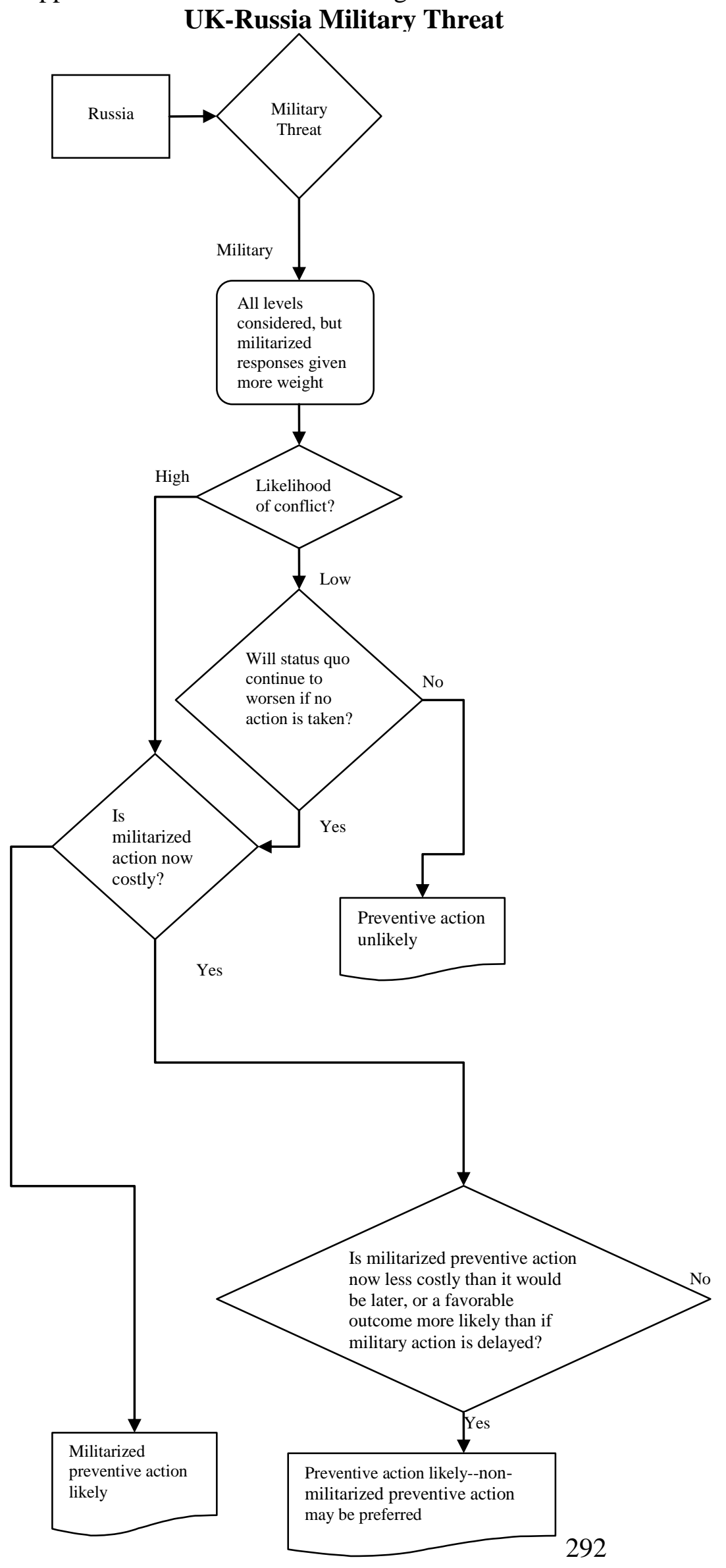


Appendix A: The Decision Making Process in the Domestic Politics Model of Prevention (DPMP) UK-Japan Military Threat

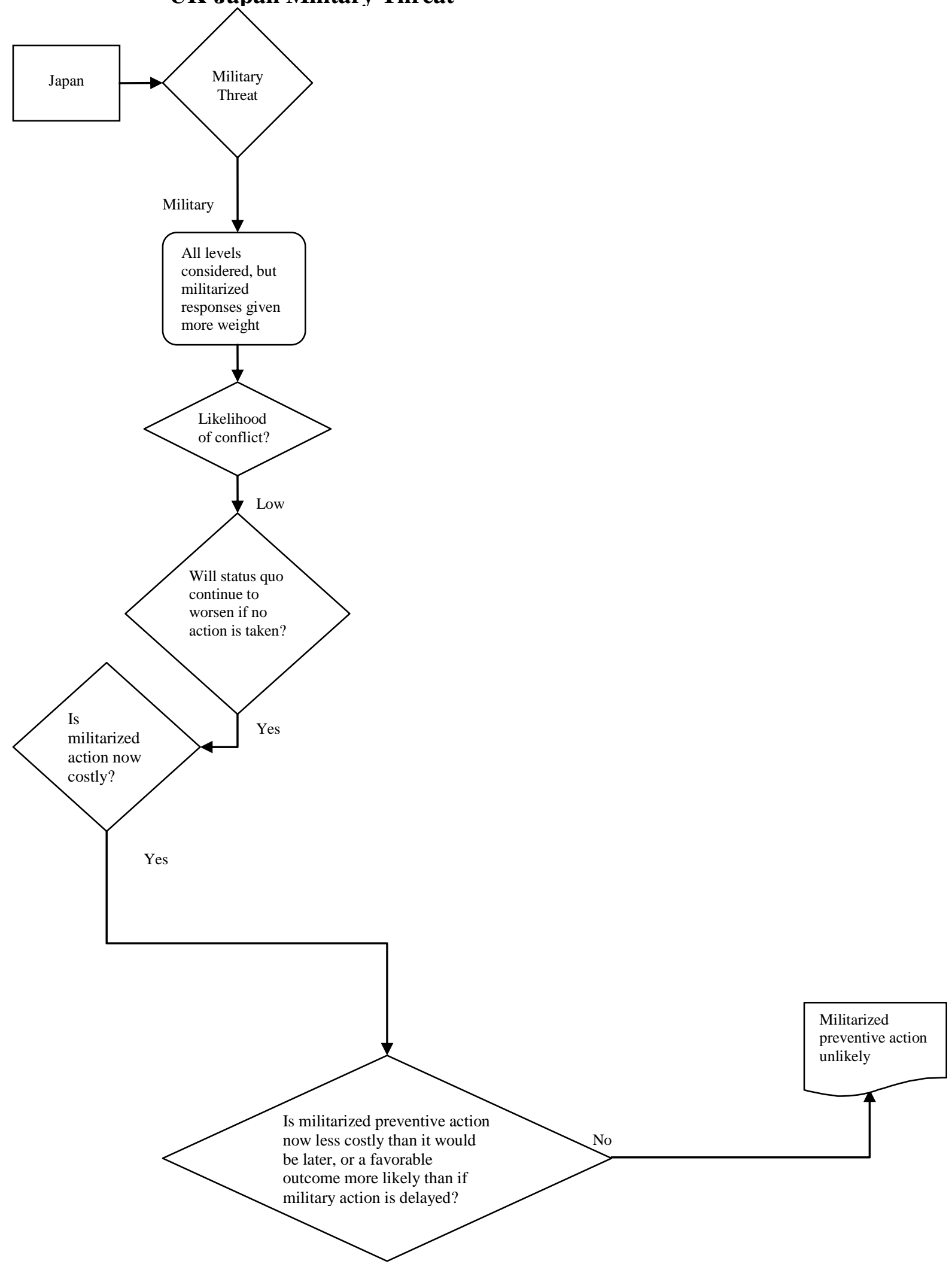


Appendix A: The Decision Making Process in the Domestic Politics Model of Prevention (DPMP)

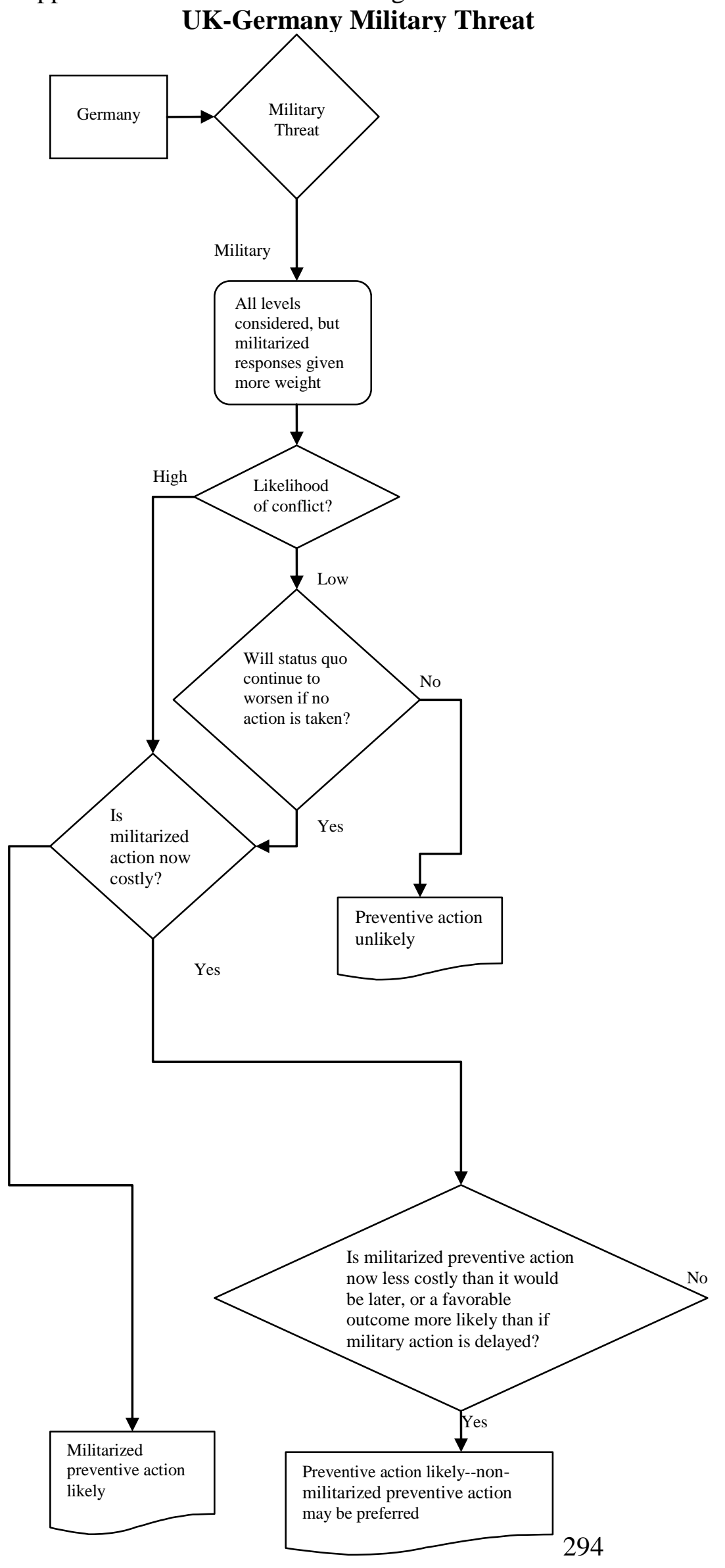


Appendix A: The Decision Making Process in the Domestic Politics Model of Prevention (DPMP) UK-Germany Economic Threat

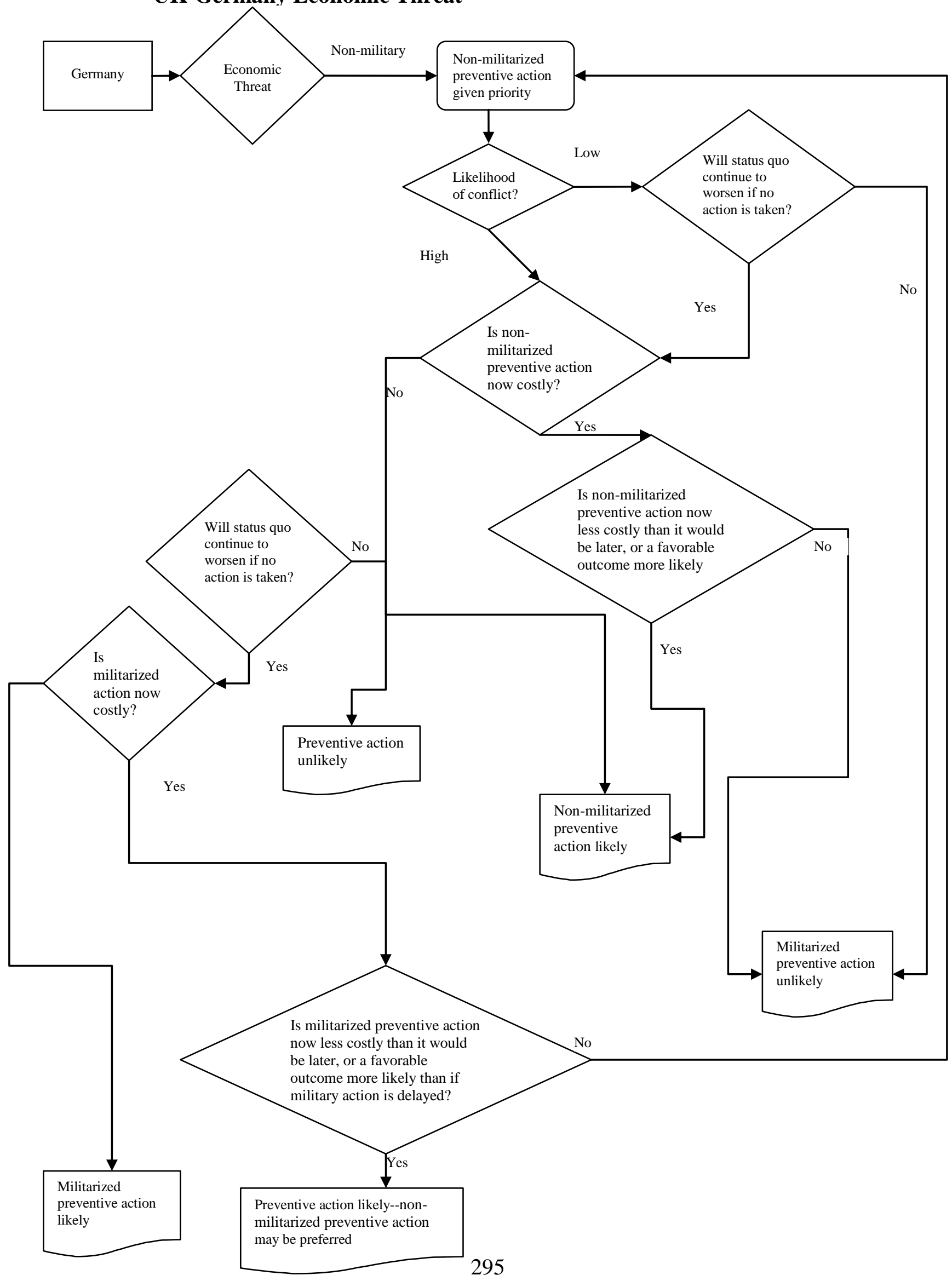


Appendix A: The Decision Making Process in the Domestic Politics Model of Prevention (DPMP)

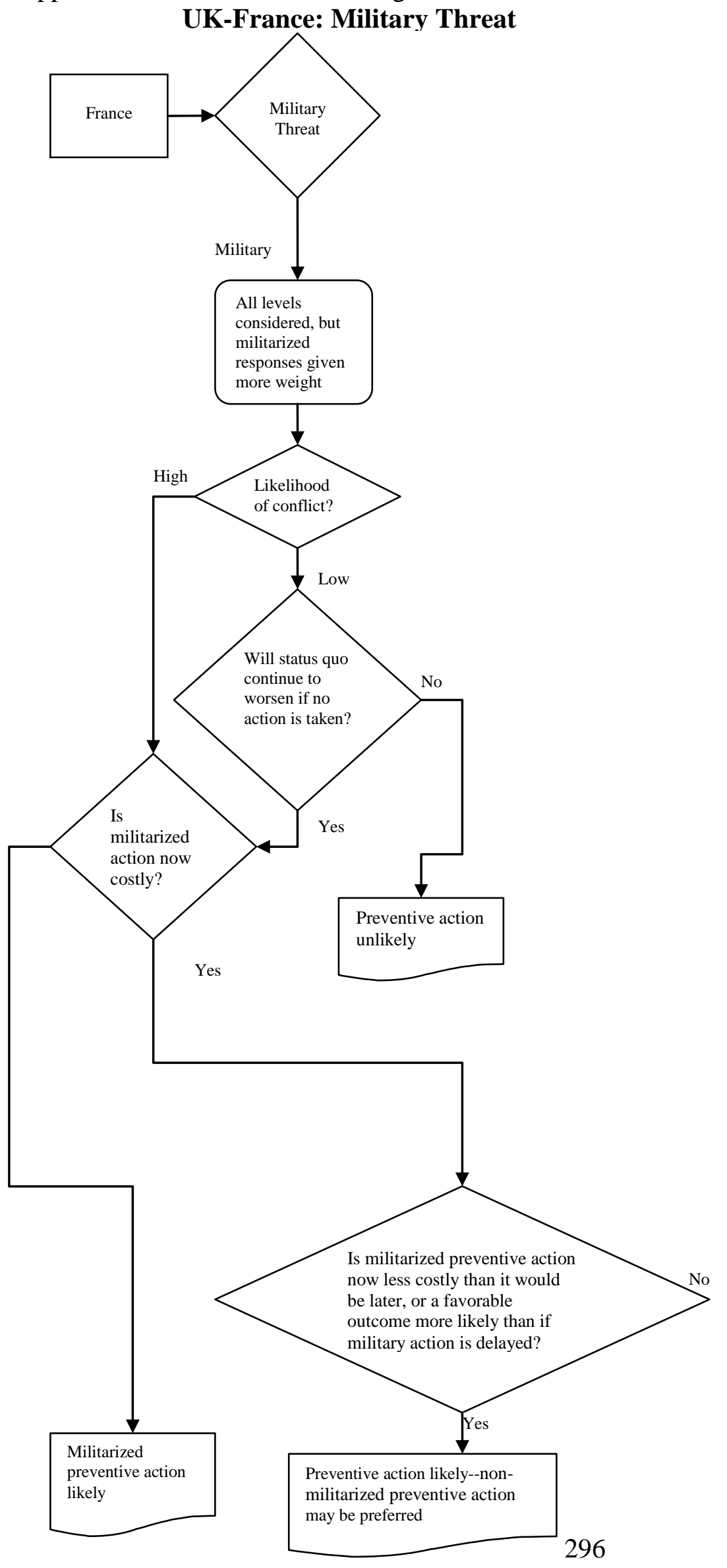


Appendix A: The Decision Making Process in the Domestic Politics Model of Prevention (DPMP) Soviet Union-United Kingdom Threat

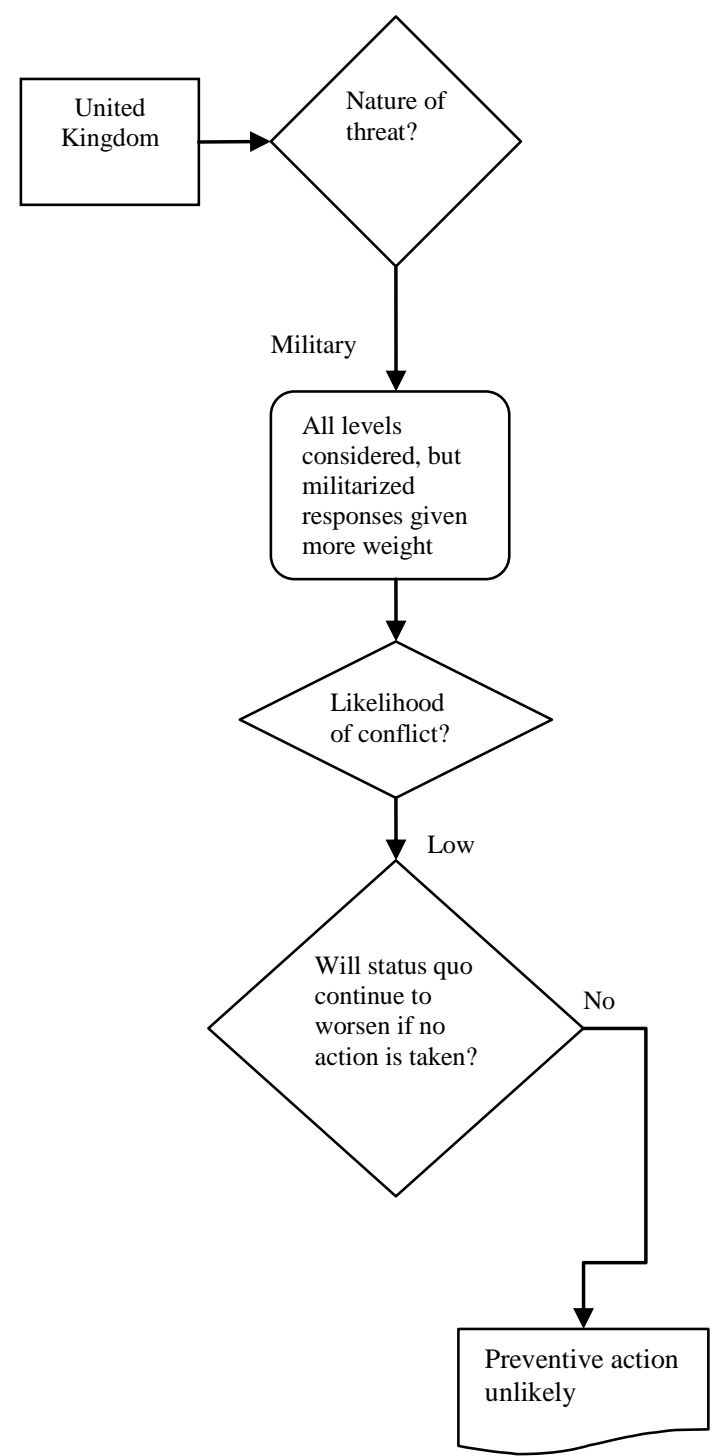


Appendix A: The Decision Making Process in the Domestic Politics Model of Prevention (DPMP) Russia-US Threat

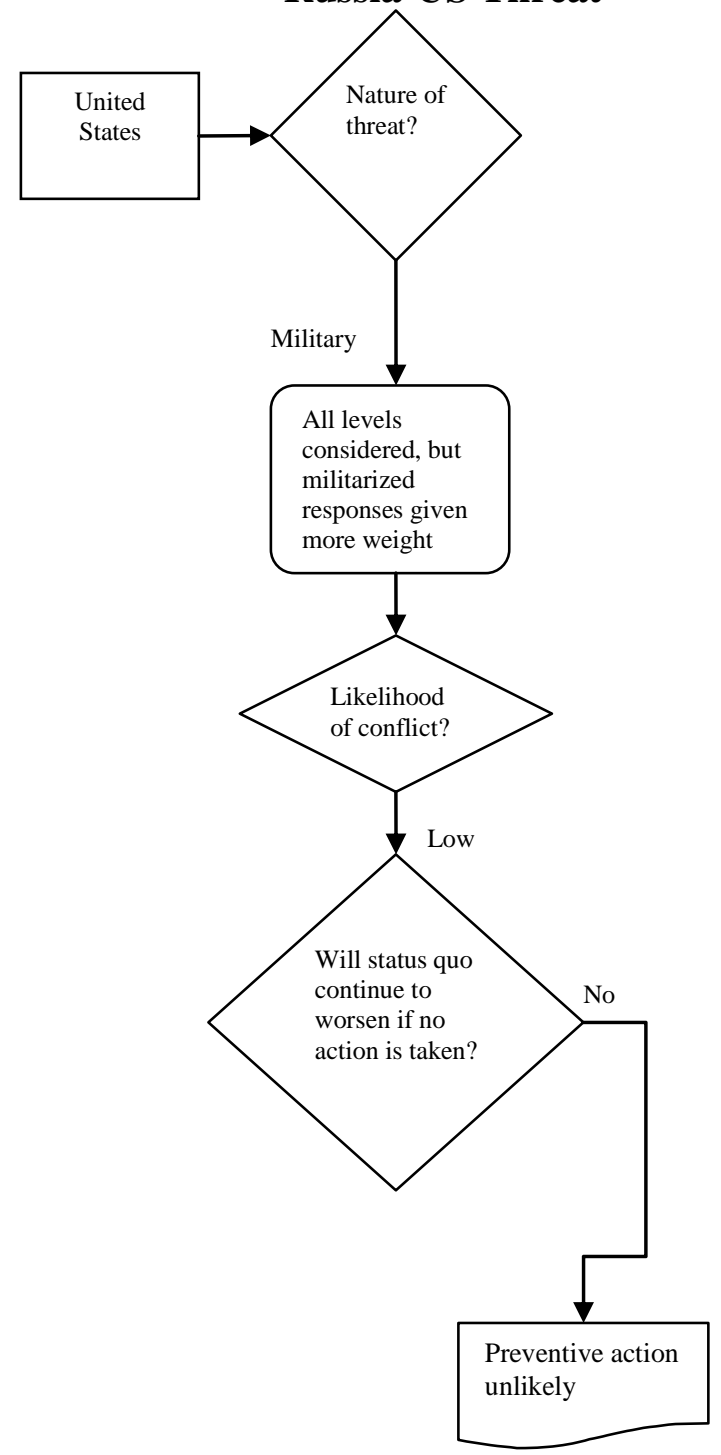


Appendix A: The Decision Making Process in the Domestic Politics Model of Prevention (DPMP) Russia/Soviet Union-Prussia/Germany Threat

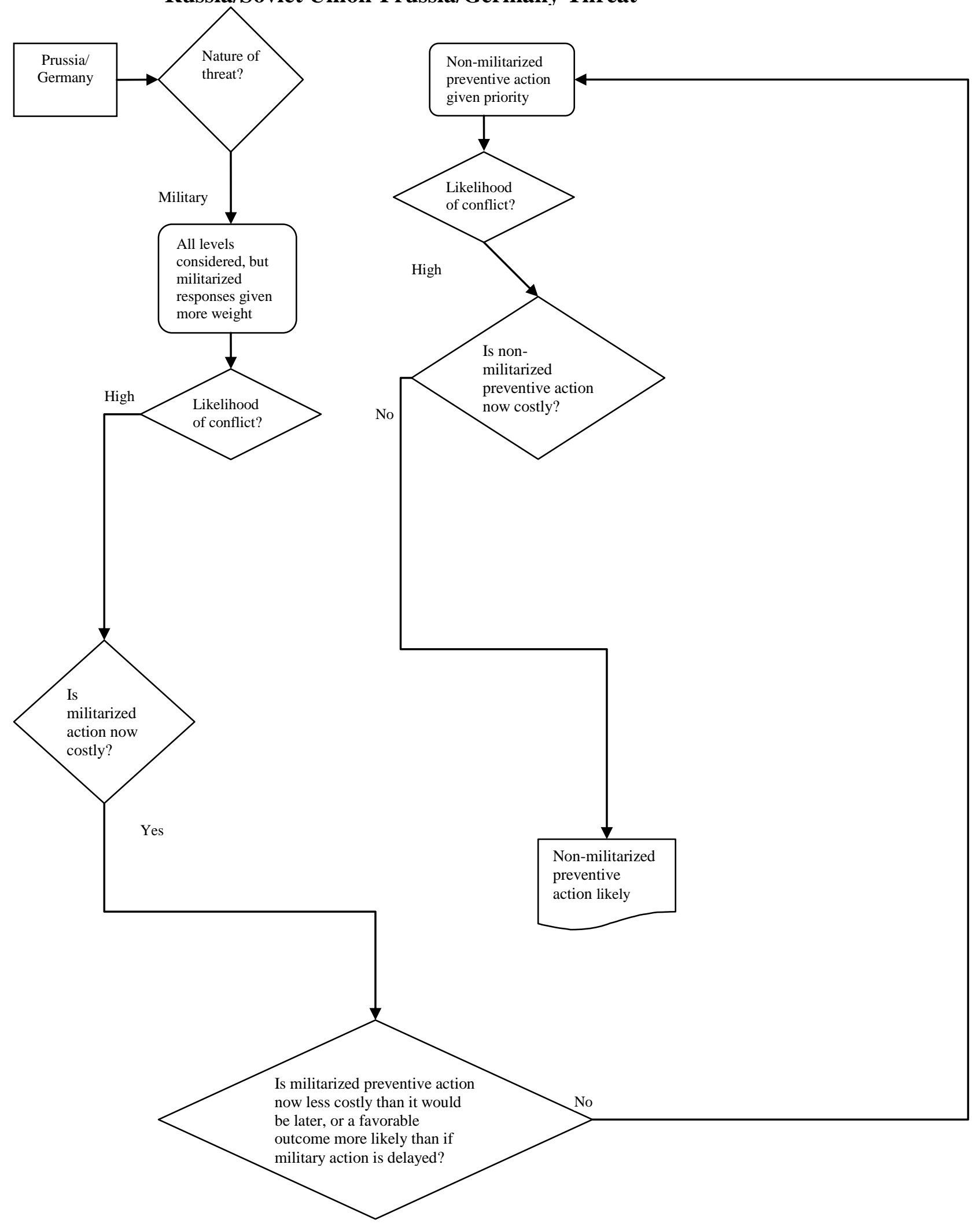


Appendix A: The Decision Making Process in the Domestic Politics Model of Prevention (DPMP) Russia-Japan 1913-1944

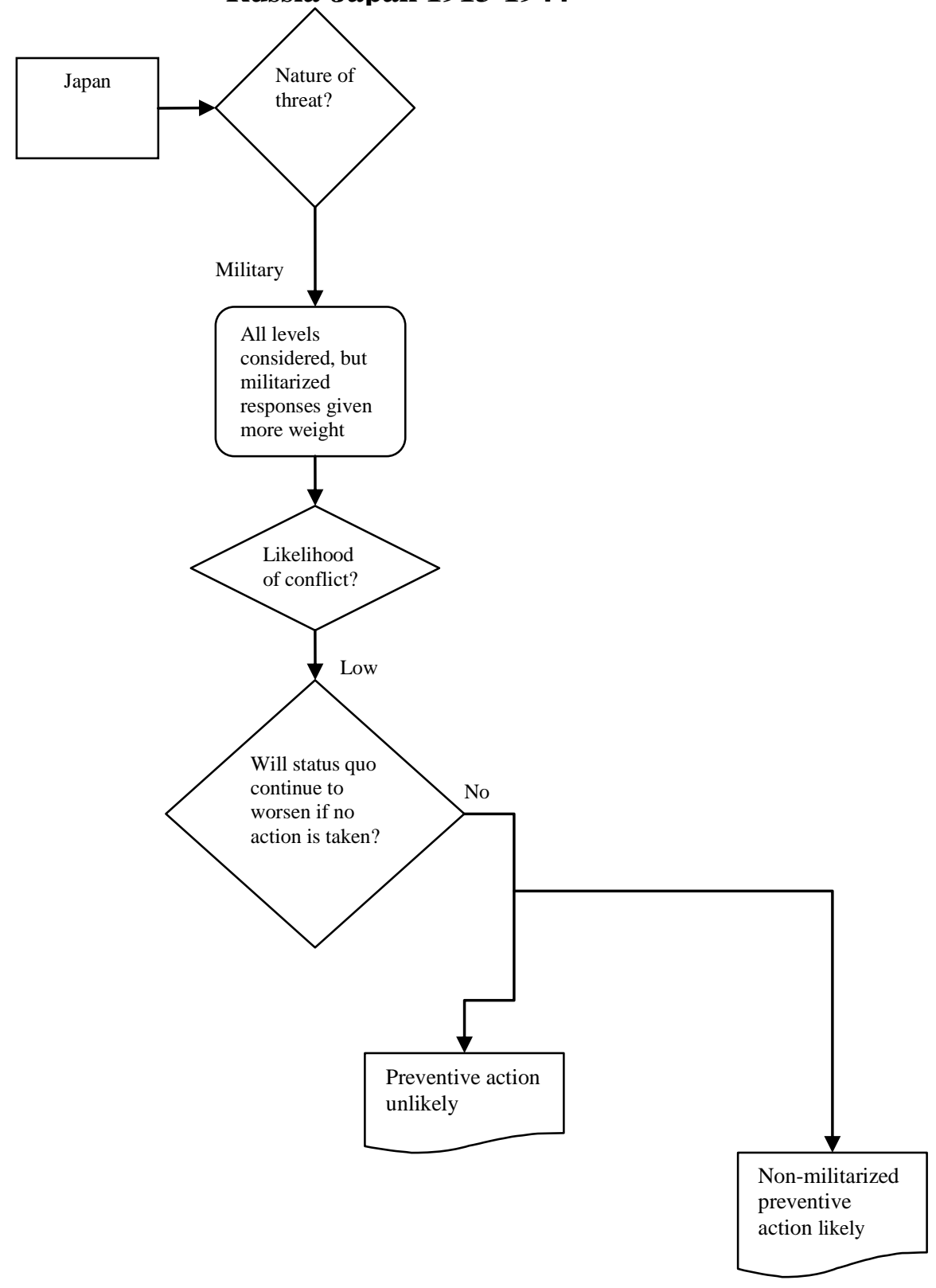


Appendix A: The Decision Making Process in the Domestic Politics Model of Prevention (DPMP) Russia-Japan 1860-1904

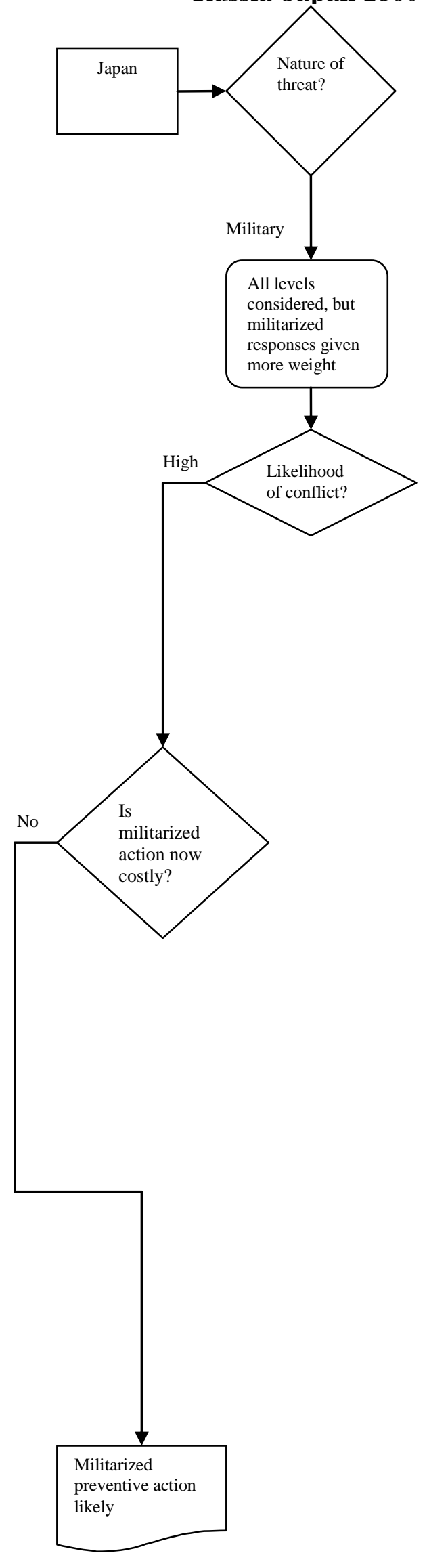


Appendix A: The Decision Making Process in the Domestic Politics Model of Prevention (DPMP) US-UK Economic Threat 1930-1939 and 1946-1996

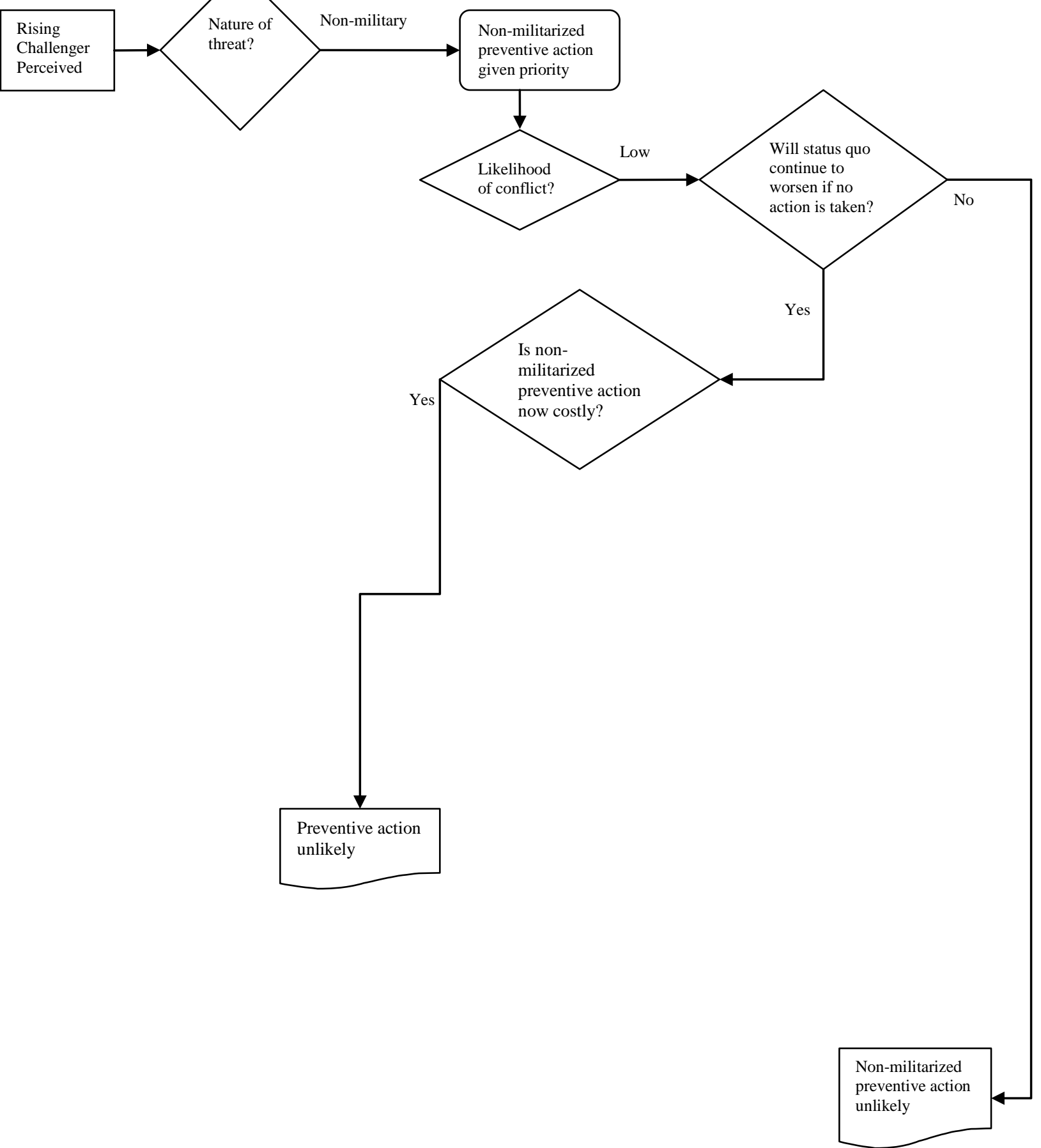


Appendix A: The Decision Making Process in the Domestic Politics Model of Prevention (DPMP)

US-Germany Military Threat 1920-1939

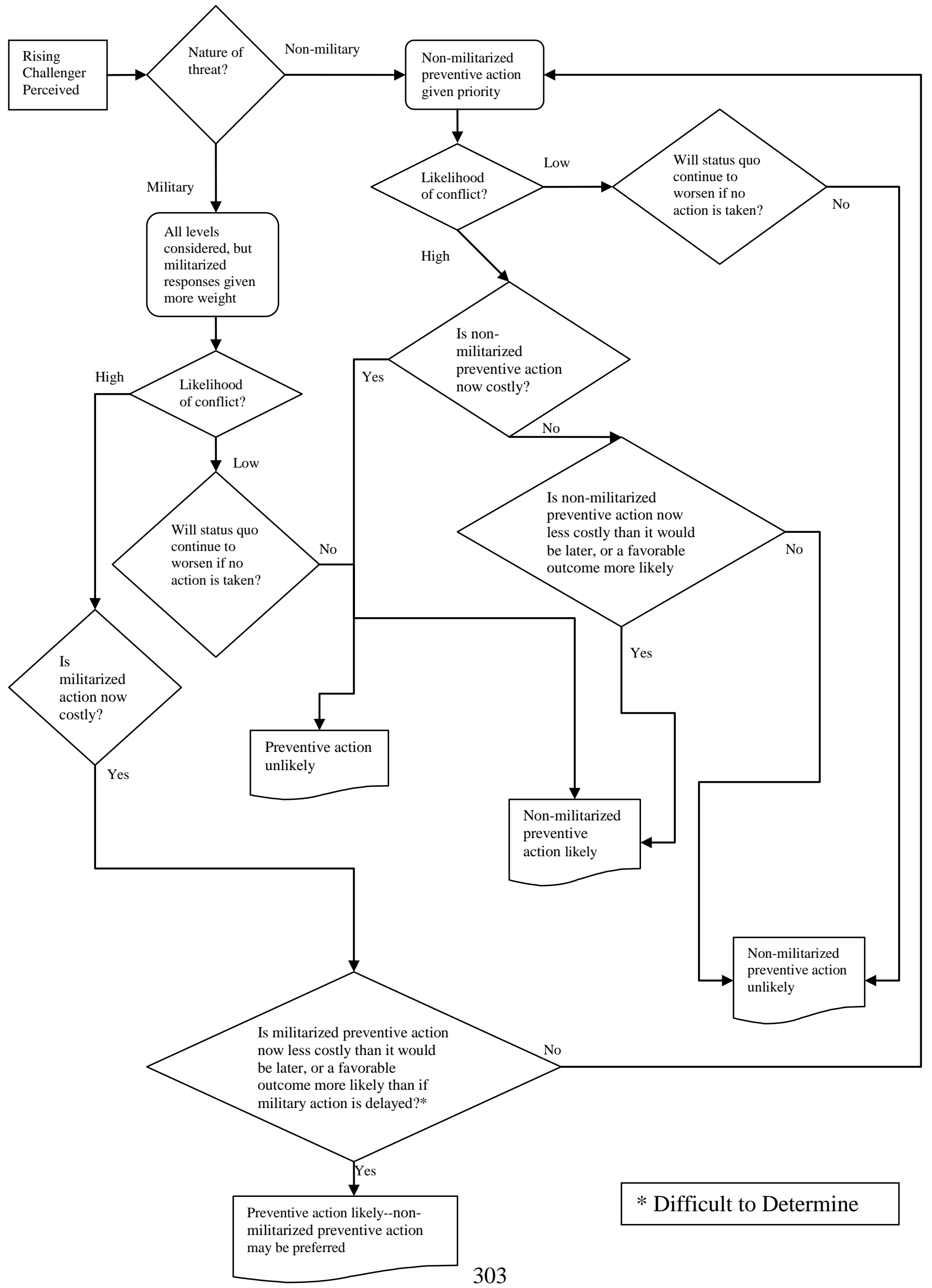


Appendix A: The Decision Making Process in the Domestic Politics Model of Prevention (DPMP)

US-Germany Economic and Military Threat 1873-1888

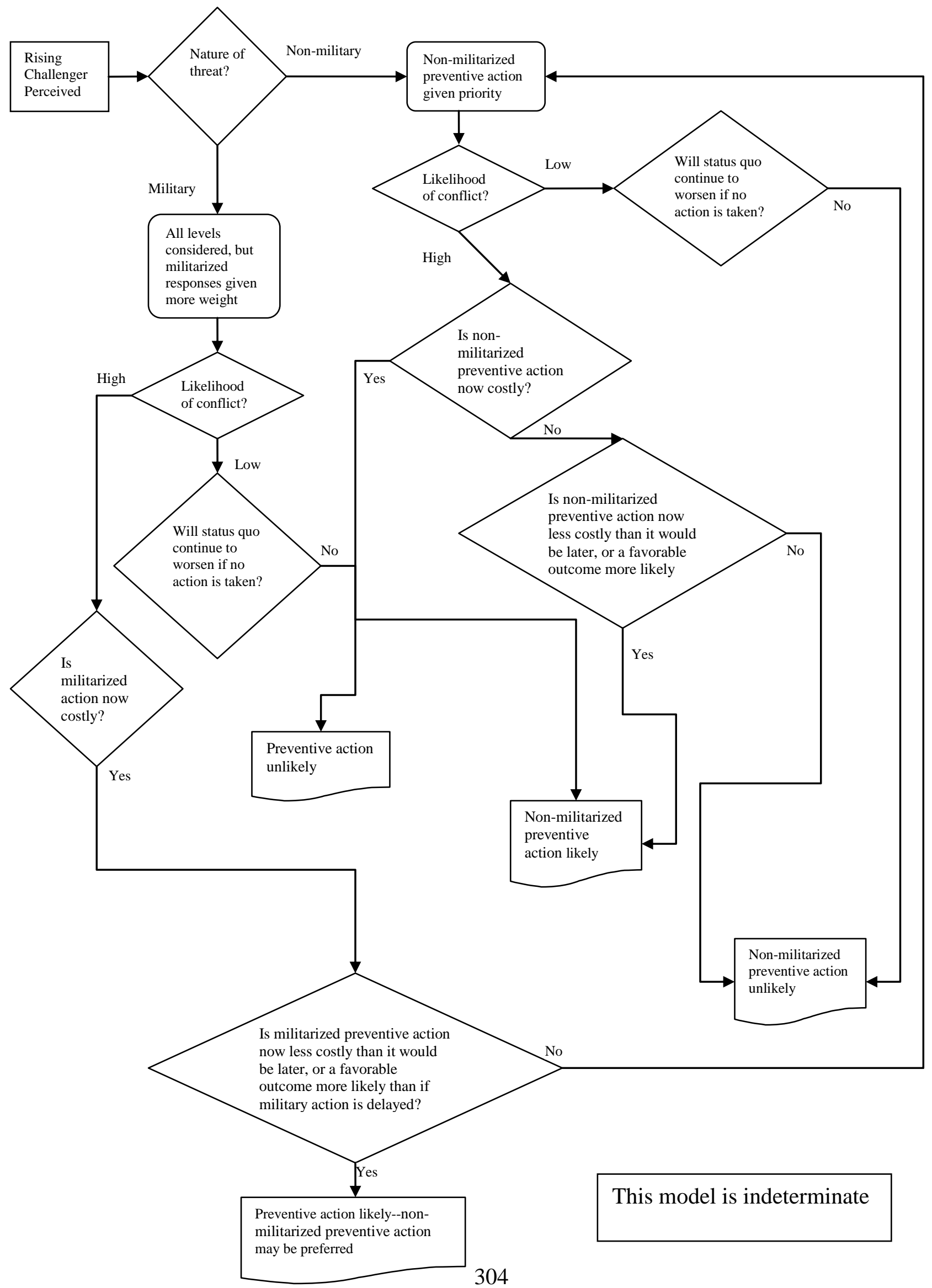


Appendix A: The Decision Making Process in the Domestic Politics Model of Prevention (DPMP) US-Soviet Union Military Threat 1946-1970

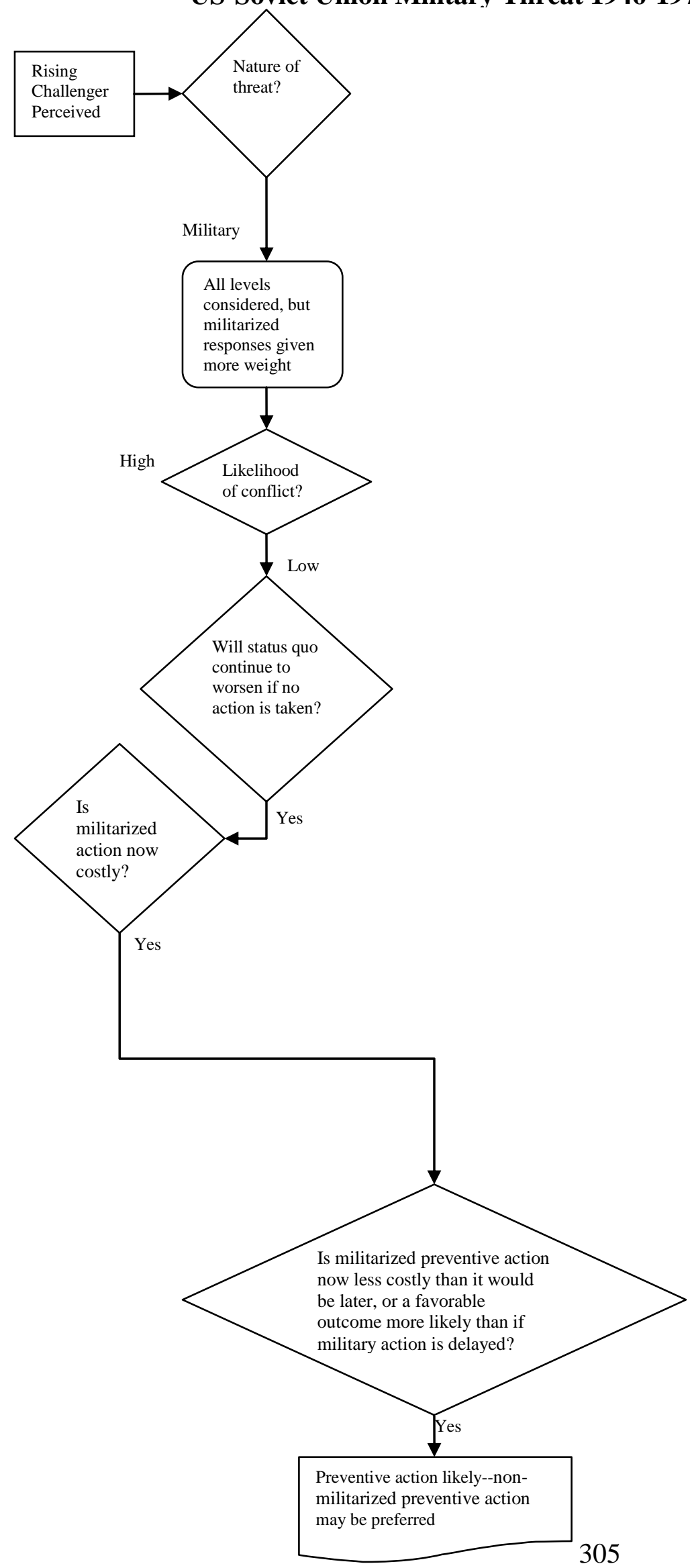


Appendix A: The Decision Making Process in the Domestic Politics Model of Prevention (DPMP) US-Soviet Union Military Threat 1920s-1938

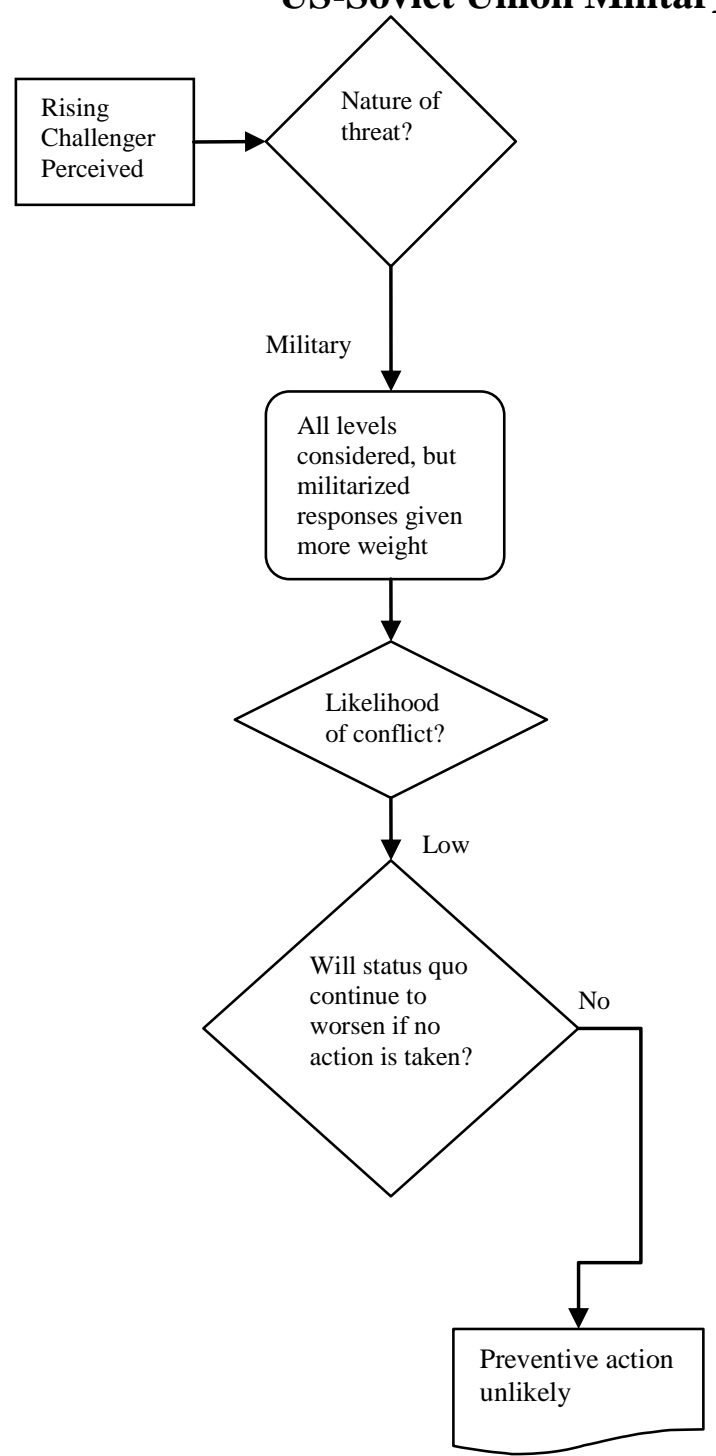


Appendix A: The Decision Making Process in the Domestic Politics Model of Prevention (DPMP)

US-Japan Military Threat 1930-1939

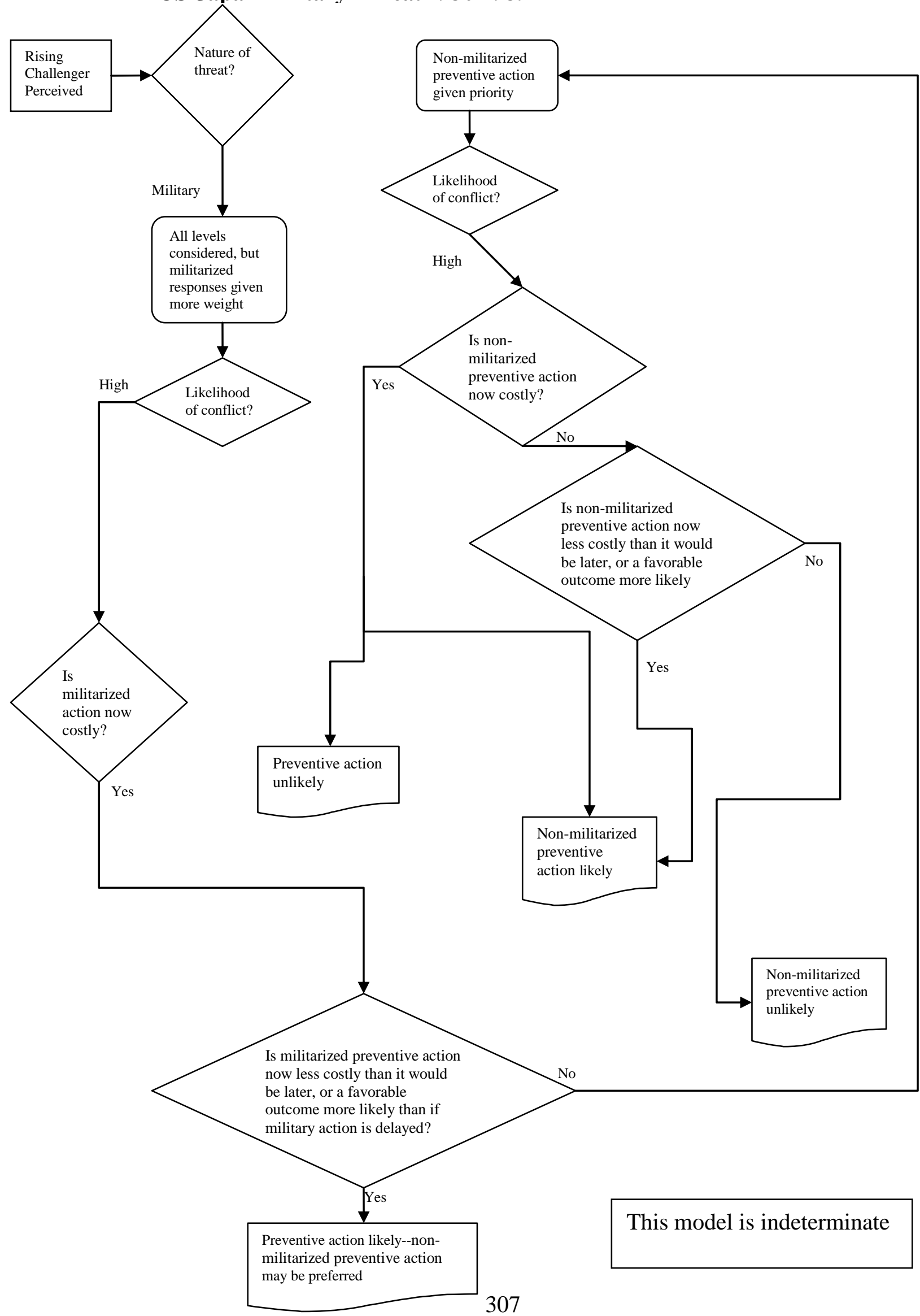


Appendix A: The Decision Making Process in the Domestic Politics Model of Prevention (DPMP) US-Japan Economic Threat 1952-1982

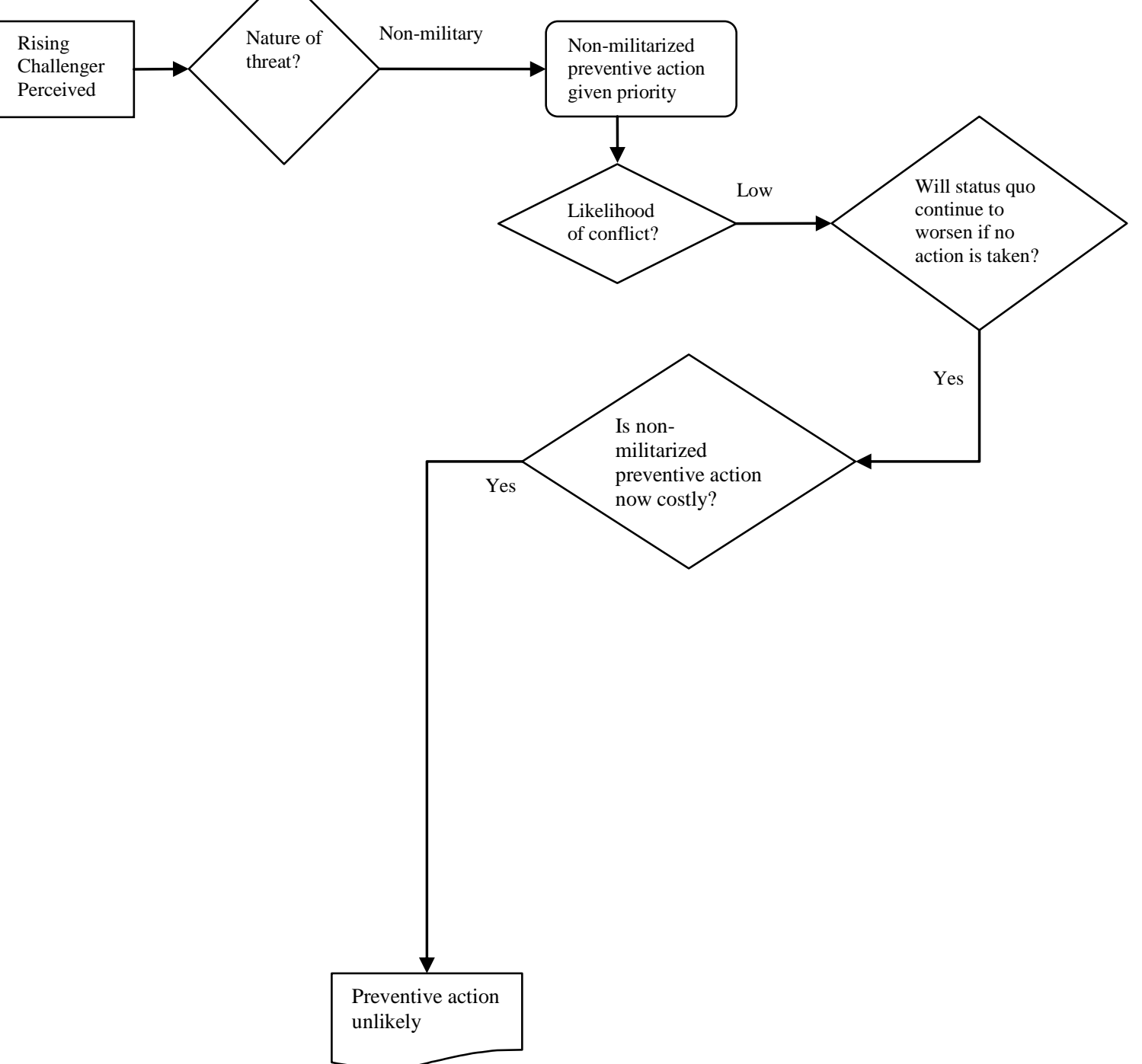


Appendix A: The Decision Making Process in the Domestic Politics Model of Prevention (DPMP) US-Japan Economic Threat 1865-1876

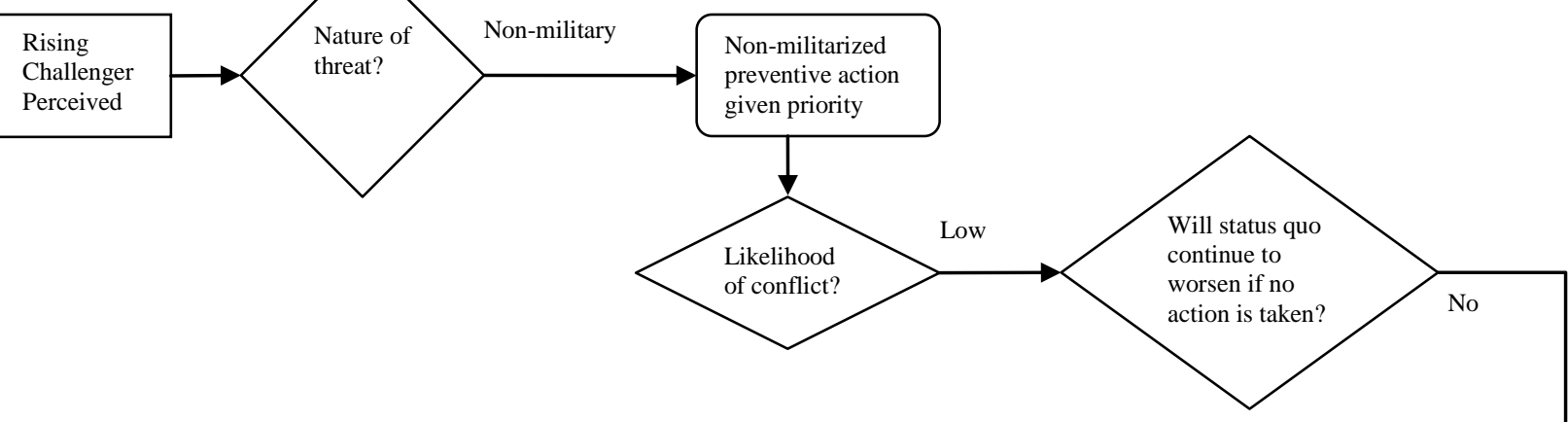


Appendix B: A Typology of Preventive Action

\section{Causal Mechanisms}

\begin{tabular}{|c|c|c|c|c|c|}
\hline & & $\begin{array}{l}\text { Systemic } \\
\text { Structure/ } \\
\text { Polarity }\end{array}$ & $\begin{array}{l}\text { Internal } \\
\text { Power } \\
\text { Constraints/ } \\
\text { Offense vs. } \\
\text { Defense }\end{array}$ & $\begin{array}{l}\text { Domestic } \\
\text { Political } \\
\text { Constraints/ } \\
\text { Pressures }\end{array}$ & $\begin{array}{l}\text { Ruler Belief } \\
\text { Systems/ } \\
\text { Perception of } \\
\text { Threats }\end{array}$ \\
\hline \multirow{4}{*}{ 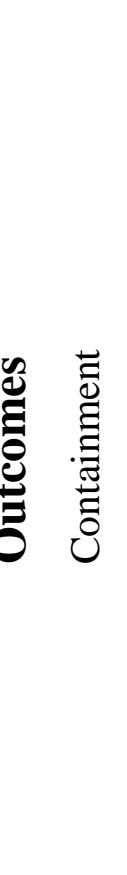 } & $\begin{array}{l}\text { Acquiescence/ } \\
\text { Do Nothing }\end{array}$ & $\begin{array}{l}\text { Bipolar/ } \\
\text { Balanced } \\
\text { Multipolar }\end{array}$ & $\begin{array}{l}\text { Severe/ } \\
\text { Defensive } \\
\text { Strategy }\end{array}$ & $\begin{array}{l}\text { Severe Political } \\
\text { Constraints/ } \\
\text { Pressure }\end{array}$ & $\begin{array}{l}\text { Moderate - } \\
\text { Acquiescent/ } \\
\text { Low - Non- } \\
\text { Militarized }\end{array}$ \\
\hline & $\begin{array}{l}\text { Accommodation/ } \\
\text { Mix of Strategies/ } \\
\text { Carrot and Stick }\end{array}$ & $\begin{array}{l}\text { Bipolar/ } \\
\text { Balanced } \\
\text { Multipolar }\end{array}$ & $\begin{array}{l}\text { Moderate/ } \\
\text { Defensive- } \\
\text { Offensive } \\
\text { Strategy }\end{array}$ & $\begin{array}{l}\text { Moderate } \\
\text { Political } \\
\text { Constraints/ } \\
\text { Pressure }\end{array}$ & $\begin{array}{l}\text { Moderate - } \\
\text { Pragmatic/ } \\
\text { Moderate - } \\
\text { Non- } \\
\text { Militarized }\end{array}$ \\
\hline & $\begin{array}{l}\text { Initiate Sustained } \\
\text { Coercive/ } \\
\text { Confrontational } \\
\text { Diplomacy } \\
\end{array}$ & $\begin{array}{l}\text { Bipolar/ } \\
\text { Unbalanced } \\
\text { Multipolar }\end{array}$ & $\begin{array}{l}\text { Moderate/ } \\
\text { Offensive- } \\
\text { Defensive } \\
\text { Strategy }\end{array}$ & $\begin{array}{l}\text { Moderate } \\
\text { Political } \\
\text { Constraints/ } \\
\text { Pressure }\end{array}$ & $\begin{array}{l}\text { Pragmatic - } \\
\text { Militant/ } \\
\text { Moderate - } \\
\text { Militarized }\end{array}$ \\
\hline & $\begin{array}{l}\text { Initiate } \\
\text { Militarized } \\
\text { Preventive Action }\end{array}$ & $\begin{array}{l}\text { Unbalanced } \\
\text { Multipolar }\end{array}$ & $\begin{array}{l}\text { Minimal/ } \\
\text { Offensive } \\
\text { Strategy }\end{array}$ & $\begin{array}{l}\text { Minimal Political } \\
\text { Constraints/ } \\
\text { Pressure }\end{array}$ & $\begin{array}{l}\text { Militant - } \\
\text { Radical/ } \\
\text { High - } \\
\text { Militarized }\end{array}$ \\
\hline
\end{tabular}


Appendix C: Selected Polity IV Scores

A negative or 0 score means that a state is considered an autocracy. A score of 1 to 6 suggests an anocracy. For the purposes of this study, I count these as non-democratic regimes. A score of 7 to 10 suggests a full democracy.

UK: 1816-1836: 4

UK: $1837-1879: 6$

UK: $1880-1900: 7$

UK: 1901-1918: 8

UK: 1919-1921: 8

UK: 1922-1989: 10

Prussia: 1816-1866: 0

Prussia: 1867: -66 (adverse transition)

Germany: 1868-1870: -88 (adverse transition)

Germany: 1871-1877: 0

Germany: 1878-1879: 1

Germany: 1890-1904: 4

Germany: 1919-9132: 6

Germany: 1933: 0

Germany: 1945: -66 (adverse transition)

West Germany: 1945-1948: -66 (adverse transition)

West Germany: 1949-1989: 10

Japan: 1860-1867: -88 (adverse transition)

Japan: 1868-1944: 5

Japan: 1945-1951: -66 (adverse transition)

Japan: 1952-1961: 10

Russia: 1816-1904: 0

Russia: 1914-1918: 1

Russia: 1919-1920: 1

USSR: 1924-1926: 0

United States: 1816-1844: 9

United States: 1845-1849: 10

United States: 1850-1853: 9

United States: 1854-1864: 8

United States: 1865-1870: 9

United States: 1871-1896: 10 